
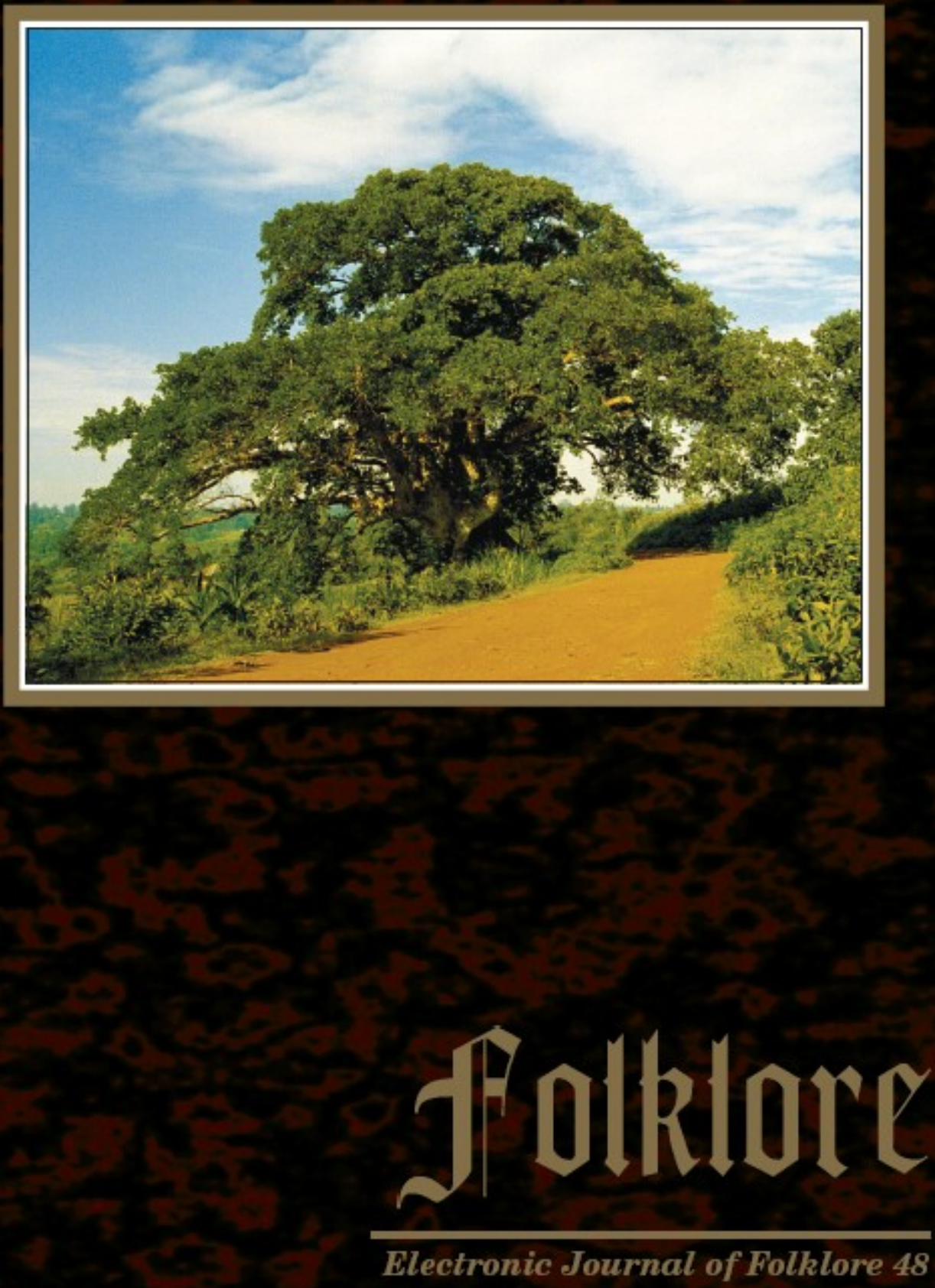
Folk Belief and Media Group of the Estonian Literary Museum

Estonian Institute of Folklore

\section{Folklore}

Electronic Journal of Folklore Vol. 48

Edited by Mare Kõiva \& Andres Kuperjanov

Tartu 2011 
Editor in chief

Co-editor

Copy editor

News and reviews

Design

Layout
Mare Kõiva

Andres Kuperjanov

Mall Leman

Maris Kuperjanov

Andres Kuperjanov

Maris Kuperjanov

Editorial board 2008-2014: Dan Ben-Amos (University of Pennsylvania, USA), Larisa Fialkova (University of Haifa, Israel), Diane Goldstein (Memorial University of Newfoundland, Canada), Terry Gunnell (University of Iceland), Jawaharlal Handoo (University of Mysore, India), Frank Korom (Boston University, USA), Monika Kropej (Institute of Slovenian Ethnology), Kristin Kuutma (University of Tartu, Estonia), Aado Lintrop (Estonian Literary Museum), Wolfgang Mieder (University of Vermont, USA), Irina Sedakova (Russian Academy of Sciences).

Electronic version is supported by Estonian Science Foundation (grant no. 8137). Printed version is supported by state programme projects EKKM09-168 and EKKM09-170.

Indexed in EBSCO Publishing Humanities International Complete, Thomson Reuters Arts \& Humanities Citation Index, MLA International Bibliography, Ulrich's Periodicals Directory, Internationale Volkskundliche Bibliographie / International Folklore Bibliography / Bibliographie Internationale d'Ethnologie), DOAJ, C.E.E.O.L.

\section{Editorial address:}

Folklore: Electronic Journal of Folklore

Vanemuise 42-235

51003 Tartu

Estonia

phone: +3727377740

fax: $\quad+3727377706$

e-mail: folklore@folklore.ee

home page: http://www.folklore.ee/folklore

All rights reserved

(C) Folk Belief and Media Group of the Estonian Literary Museum

EKM Teaduskirjastus/ELM Scholarly Press

Estonian Institute of Folklore

Authors

Design Andres Kuperjanov

ISSN 1406-0957 


\section{CONTENTS}

On the Present-day Veneration of Sacred Trees in the Holy Land Amots Dafni

Chaotic Identities, Love and Fathering

Stephen Williams

Connecting Threads

55

Mirjam Mencej

The Discursive Suppression of Women: Female Evils as

the Villains of the Motherhood Narrative

Leyla Önal

Folk Narratives and Legends as Sources of Widespread Idioms:

Toward a Lexicon of Common Figurative Units

Elisabeth Piirainen

Images of Birds in Mordvinian Mythology

Tatiana Deviatkina

Rites Associated with Conjuring Rain in the Udmurt Calendar Cycle 153

Tatiana Vladykina, Galina Glukhova

The Tallinn Department of the Estonian National Museum:

History and Developments

Piret Õunapuu

NEWS IN BRIEF

Dissertation on Hidden Treasures in Estonian Tale Tradition. Katre Kikas

Thesis Defence: Piret Voolaid. Estonian Riddles as a Folklore Genre

in a Changing Cultural Context. Sirkka Saarinen

Fragments from the Convention of Ethnographers and Folklorists.

SIEF Congress in Lisbon, April 17-21, 2011. Tiiu Jaago, Pihla Siim

Taking Malta Out of the Box. Mare Kõiva

Book REvIEWs

Words as Events or Events as Words? Kanni Labi 


\title{
ON THE PRESENT-DAY VENERATION OF SACRED TREES IN THE HOLY LAND
}

\author{
Amots Dafini
}

\begin{abstract}
This article surveys the current pervasiveness of the phenomenon of sacred trees in the Holy Land, with special reference to the official attitudes of local religious leaders and the attitudes of Muslims in comparison with the Druze as well as in monotheism vs. polytheism. Field data regarding the reasons for the sanctification of trees and the common beliefs and rituals related to them are described, comparing the form which the phenomenon takes among different ethnic groups. In addition, I discuss the temporal and spatial changes in the magnitude of tree worship in Northern Israel, its syncretic aspects, and its future.
\end{abstract}

Key words: Holy land, sacred tree, tree veneration

\section{INTRODUCTION}

Trees have always been regarded as the first temples of the gods, and sacred groves as their first place of worship and both were held in utmost reverence in the past (Pliny 1945: 12.2.3; Quantz 1898: 471; Porteous 1928: 190). Thus, it is not surprising that individual as well as groups of sacred trees have been a characteristic of almost every culture and religion that has existed in places where trees can grow (Philpot 1897: 4; Quantz 1898: 467; Chandran \& Hughes 1997: 414). It is not uncommon to find traces of tree worship in the Middle East, as well. However, as William Robertson-Smith (1889: 187) noted, "there is no reason to think that any of the great Semitic cults developed out of tree worship".

It has already been recognized that trees are not worshipped for themselves but for what is revealed through them, for what they imply and signify (Eliade 1958: 268; Zahan 1979: 28), and, especially, for various powers attributed to them (Millar et al. 1999: 35; Hamilton 2002: 57). In addition, they are sometimes seen to be the abode of supreme beings (see Dafni 2006 for a review). Sacred trees are thus treated as any other sacred space, and it is therefore not surprising that many of the customs and ceremonies observed in sacred places, in general, are also observed at the sites of sacred trees. 
In the Muslim world and in the Middle East, sacred places are closely related to the worship of saints (Goldziher 1971: passim; Westermarck 1973, 1968: passim; Canaan 1927: passim; Arráf 1993: passim; Anabsi 2008: passim; Subtelny 1989: passim; Culmsee et al. 2005: 187-189), and in many instances sacred trees are connected with sacred graves/shrines and share common supernatural powers: to grant divine blessings, to cure, and to punish offenders of the saint to whom the tree is dedicated and who endows the tree with its miraculous powers (Canaan 1927: passim; Dafni 2002, 2006, 2007a).

Pamela R. Frese and S. J. M. Gray (1995: 32) note: "Sacred trees have a ritual significance. The trees and their meanings may be incorporated into rituals of curing, initiation, marriage and death. Trees used in any of these contexts stand for the divine and represent the sacred beliefs being honoured through the ritual." In the same vein, Canaan (1927: 151) adds: "The presentday peasant does not venerate the trees themselves but the divine power which acts in them and which is derived from a godly person whose soul is supposed to be inhabiting the shrine, tomb, cave or spring with which they became associated. Often these holy men have appeared in the tree itself or near by."

Regarding this point, it is pertinent to cite John Mills (1864: 54) who declared: "Yet in no country are the people more awed by trees than in Palestine."

The current article, based on extensive fieldwork, surveys some aspects of the contemporary prevalence of tree worship in present day Israel, with special emphasis on the reasons for the sanctification of trees and the customs related to them. Also traced are the changes in the extent of the phenomenon over the past few generations and among the various religions.

\section{METHODOLOGY}

The field study, performed between 1999 and 2006, centred on thirty-five Arab, Bedouin, and Druze villages in the Galilee. Informants were asked, in an unstructured interview, about the reasons why certain trees became sacred, the existence of sacred trees (including historical and abandoned ones), who visit these trees and for what purposes, what the attitude of their religion is to tree worship, what supernatural powers are attributed to and what customs and ceremonies are observed near or under sacred trees.

The survey covered 158 informants, comprising 47 Druze and 111 Muslims (54 Arabs and 57 Bedouins). The distinction between Bedouins and Arabs was made in an attempt to expose any differences in traditions regarding sacred trees that may reflect differences between nomads and settled village people. 
I took Arabs to be people settled in their villages for several centuries, and Bedouins to be people who originated in the deserts of Israel and Jordan, and migrated to Galilee during the last three centuries, and were nomads until the end of the 20th century (Medzini 1984: 30).

The Druze are an eastern Mediterranean religious group first established in Egypt in the 11th century (Dana 2003: 3). Today they are concentrated in Lebanon, Syria, and Israel (Dana 2003: 8-14). Their belief in the revelation of God in the form of a human being is the most important fundamental principle of the Druze faith (Besterman 1928: 145; Dana 2003: 15). This is not in essence a ritual and ceremonial belief system, but rather a Neo-Platonic philosophy (Dana 2003: 17).

The survey excluded Christians, who rarely believe in sacred trees, while tree worship among Jews is a new trend which appeared in the last two decades. Almost all the trees worshipped by Jews are revered already by Muslims and grow in the vicinity of graves of Jewish personalities regarded as righteous.

In each village I carried out a preliminary survey to locate, a priori, the more knowledgeable people. I also sought important religious leaders to enquire of their attitudes to the worship of sacred trees. I chose informants according to their knowledge of common/local traditions and/or religious status. The average age of the informants was 53.7 (+/-13.6) years. Respondents comprised 126 males and 32 females (in general, women were reluctant to be interviewed and, when they agreed, the interview was held in the presence of other family members). Because of the refusal of most of the informants to be videotaped or to have their statements recorded, the study is based entirely on oral interviews and field notes taken on the spot. I also surveyed 78 known sacred trees of which 37 are active centres of worship today. (Numbers in bold in the text indicate how many informants gave a certain answer).

\section{RESULTS}

Table 1. The ethnic distribution of the sacred trees in Northern Israel

\begin{tabular}{|l|c|c|c|c|}
\hline $\begin{array}{l}\text { Ethnic/religious } \\
\text { group }\end{array}$ & Active & Abandoned & $\begin{array}{c}\text { Disappeared } \\
\text { during the last } \\
\text { decade }\end{array}$ & $\begin{array}{c}\text { In } \\
\text { cemeteries }\end{array}$ \\
\hline Arabs & 9 & 14 & 1 & 1 \\
\hline Bedouins & 11 & 8 & 6 & 3 \\
\hline Druze & 17 & 2 & 0 & 0 \\
\hline Jewish & 6 & 0 & 0 & 2 \\
\hline Syncretic & 4 & 0 & 0 & 0 \\
\hline
\end{tabular}


Table 2. Reasons for the sanctification of trees as related to the ethnic/religious groups in Northern Israel

\begin{tabular}{|c|c|c|c|c|}
\hline Reason & $\begin{array}{c}\text { Druze } \\
\mathrm{N}=38\end{array}$ & $\begin{array}{l}\text { Arab } \\
\mathrm{N}=36\end{array}$ & $\begin{array}{c}\text { Bedouins } \\
\mathrm{N}=\mathbf{2 3}\end{array}$ & $\begin{array}{l}\text { Records from other } \\
\text { countries }\end{array}$ \\
\hline \multicolumn{5}{|l|}{ Syncretic reasons } \\
\hline $\begin{array}{l}\text { Religious/social meetings } \\
\text { take place under the tree; } \\
\text { well known figures are } \\
\text { associated with the tree. }\end{array}$ & 71 & 44.4 & 30.4 & $\begin{array}{l}\text { Ancient Assyria, Iran, Morocco, } \\
\text { India }\end{array}$ \\
\hline $\begin{array}{l}\text { The tree is dedicated to a } \\
\text { prophet. }\end{array}$ & 47.3 & 22.2 & 34.7 & \\
\hline $\begin{array}{l}\text { The tree/forest } \\
\text { commemorates events in } \\
\text { the lives of saints, heroes, } \\
\text { kings, in the tribe's } \\
\text { history etc. }\end{array}$ & 36.8 & 41.6 & 26 & $\begin{array}{l}\text { Ancient Assyria, Ancient } \\
\text { Britain, Ireland, England, } \\
\text { Morocco, Mozambique, Uganda, } \\
\text { Iran, India, Nepal, Okinawa, } \\
\text { New Zealand }\end{array}$ \\
\hline $\begin{array}{l}\text { The tree is religiously } \\
\text { blessed. }\end{array}$ & 26.3 & 19.4 & 17.3 & India, East Asia \\
\hline $\begin{array}{l}\text { The tree sprouted from a } \\
\text { saint's staff. }\end{array}$ & 7.8 & 11.1 & 4.3 & $\begin{array}{l}\text { England, Ireland, Poland, } \\
\text { Morocco, Iran, India, New } \\
\text { Zealand }\end{array}$ \\
\hline \multicolumn{5}{|l|}{$\begin{array}{l}\text { Exclusive/differential } \\
\text { reasons }\end{array}$} \\
\hline $\begin{array}{l}\text { The tree is the abode of a } \\
\text { Welli 'saint's spirit'. }\end{array}$ & 0 & 58.3 & 52 & Iraq, Turkey \\
\hline $\begin{array}{l}\text { A saint was buried } \\
\text { near/under the tree. }\end{array}$ & 2.6 & 52.7 & 21.7 & \\
\hline $\begin{array}{l}\text { The tree shows the way to } \\
\text { a sacred place. }\end{array}$ & 92 & 0 & 0 & \\
\hline $\begin{array}{l}\text { The tree provides shade } \\
\text { in the desert. }\end{array}$ & 0 & 0 & 17.3 & \\
\hline
\end{tabular}

Modified from Amots Dafni (2006), which includes full citations; the numbers indicate the percentage of the informants that mentioned each reason.

Table 3. Customs related to sacred trees as related to the ethnic/religious groups in Northern Israel

\begin{tabular}{|l|c|c|c|l|}
\hline Issue & $\begin{array}{c}\text { Druze } \\
\mathbf{N = 3 4}\end{array}$ & $\begin{array}{c}\text { Arab } \\
\mathbf{N = 4 5}\end{array}$ & $\begin{array}{l}\text { Bedouins } \\
\mathbf{N = 2 9}\end{array}$ & $\begin{array}{l}\text { Records from other } \\
\text { countries }\end{array}$ \\
\hline Syncretic customs & & & & \\
\hline Rag tying. & 73.5 & 84.4 & 68.9 & Many countries worldwide \\
\hline $\begin{array}{l}\text { Animal sacrifice (when vows are } \\
\text { fulfilled). }\end{array}$ & 50 & 42.2 & 48.2 & Lebanon, Syria, India \\
\hline $\begin{array}{l}\text { Leaving objects under/on the } \\
\text { tree to absorb Barakeh 'divine } \\
\text { blessing'. }\end{array}$ & 38.2 & 71.1 & 37.9 & \\
\hline $\begin{array}{l}\text { Personal wows, health/personal } \\
\text { petitions. }\end{array}$ & 58.8 & 71.1 & 62.0 & $\begin{array}{l}\text { Scotland, Estonia, Serbia, } \\
\text { Russia, Middle East, East } \\
\text { and Central Africa, } \\
\text { India, Japan, Australia, } \\
\text { New Zealand }\end{array}$ \\
\hline Weddings under the tree. & 17.1 & 28.8 & 51.7 & India \\
\hline
\end{tabular}




\begin{tabular}{|c|c|c|c|c|}
\hline $\begin{array}{l}\text { Religious/social meetings under } \\
\text { the tree. }\end{array}$ & 23.5 & 26.6 & 31.0 & $\begin{array}{l}\text { Russia, Sierra Leone, } \\
\text { Tanzania, India, Korea, } \\
\text { Indonesia, American } \\
\text { Indians }\end{array}$ \\
\hline Pilgrimage/family gatherings. & 11.0 & 23.0 & 13.8 & \\
\hline Lighting candles/lamps. & 23.5 & 31.1 & 24.1 & $\begin{array}{l}\text { Lebanon, Turkey, Balkan, } \\
\text { Russia, Uganda, Armenia, } \\
\text { India }\end{array}$ \\
\hline Hammering of nails. & 8.8 & 8.9 & 17.2 & $\begin{array}{l}\text { Egypt, Turkey, Kurdistan, } \\
\text { Austria, Russia, Ireland, } \\
\text { India, West Himalaya }\end{array}$ \\
\hline $\begin{array}{l}\text { Placing stones on/under the tree } \\
\text { or in heaps/cairns. }\end{array}$ & 2.9 & 8.9 & 10.3 & Russia, India, Korea \\
\hline $\begin{array}{l}\text { Burning incense (as a part of a } \\
\text { personal form of praying). }\end{array}$ & 5.9 & 24.4 & 17.2 & Armenia, India \\
\hline $\begin{array}{l}\text { Leaving objects/ food under the } \\
\text { tree as charity. }\end{array}$ & 26.4 & 15.5 & 20.6 & \\
\hline \multicolumn{5}{|l|}{$\begin{array}{l}\text { Exclusive/differential } \\
\text { customs }\end{array}$} \\
\hline $\begin{array}{l}\text { Funeral/ burial/under the } \\
\text { tree/in the sacred grove (of } \\
\text { leaders and heroes). }\end{array}$ & 0 & 20.0 & 24.1 & $\begin{array}{l}\text { Ancient Israelite, } \\
\text { Mongolia, Zimbabwe, } \\
\text { Kenya, Ghana, } \\
\text { Mozambique, Tanzania, } \\
\text { Okinawa, }\end{array}$ \\
\hline $\begin{array}{l}\text { Embracing/touching/kissing of } \\
\text { the tree. }\end{array}$ & 55.9 & 4.4 & 6.9 & Ancient Rome \\
\hline Rain making ceremonies. & 0 & 15.5 & 27.5 & $\begin{array}{l}\text { Ancient Rome, North East } \\
\text { and Central Africa, } \\
\text { Arabia, India, Papua }\end{array}$ \\
\hline $\begin{array}{l}\text { Passing judgment under the } \\
\text { tree. }\end{array}$ & 0 & 4.4 & 27.5 & $\begin{array}{l}\text { Ancient Israelites, } \\
\text { Morocco, France, } \\
\text { Germany, Switzerland, } \\
\text { Somalia, India, Japan }\end{array}$ \\
\hline $\begin{array}{l}\text { Sulkha 'conciliation of quarrels' } \\
\text { under the tree. }\end{array}$ & 0 & 0 & 20.6 & \\
\hline $\begin{array}{l}\text { Decoration of tree (with leader's } \\
\text { pictures, lights). }\end{array}$ & 14.7 & 0 & 0 & \\
\hline Leaving water under the tree. & 0 & 8.9 & 13.8 & \\
\hline $\begin{array}{l}\text { Praying while passing near the } \\
\text { tree. }\end{array}$ & 0 & 7.7 & 6.9 & \\
\hline
\end{tabular}

Modified from Dafni (2006), which includes full citations; the numbers indicate the percentage of the informants that mentioned each custom.

\section{DISCUSSION AND CONCLUSIONS}

\section{Holy and sacred vs. blessed trees}

In order to clarify the "sacred" status of trees, it is necessary to elucidate the conceptual differences between "blessed", "sacred", and "holy". The difference is not only semantic, but reflects religious attitudes concerning the adoration of trees. According to Druze tradition, only people such as prophets can be "sacred", while only physical objects such as trees can be regarded as "blessed" 
(Dafni et al. 2005). Frederick J. Simoons (1998: 293) distinguishes "holy trees", such as the sacred fig or Bo-tree (Ficus religiosa L.), where all the members of certain species are venerated, from individual "sacred trees" which are locally adored because of special characteristics, or which have been given respect due to their location in a holy place or because of their association with a holy person. In many cultures it is traditional that all specimens of a given botanical species are equally venerated. The only tree in the Middle East that could possibly be regarded as a "Holy tree" is Christ's Thorn Jujube (Ziziphus spina christi), which is mentioned in the Quran. All the trees of this species are highly respected, but are worshipped only in connection with a righteous person and not in and of themselves.

An old Muslim legend recounts that Christ's Thorn Jujube, which also grows in Paradise, has as many leaves as there are human beings. Each leaf bears the name of a particular person, as well as the names of that person's parents. Every year, on one day in the middle of the month of Ramadan, just after sunset, the tree is shaken. The names on the leaves that fall are of those who will face death in the coming year. The processes of leaf decay indicate the timing of their death; some leaves dry up and fall immediately while others wither slowly, indicating the amount of time remaining to that person (Rodwell 1937: 69; Zwemer 1920: 69). This legend reflects the respect which Muslims accord to all of Christ's Thorn Jujube trees, wherever they are. The special attitude to the Christ's Thorn Jujube can be summarized and explained as the traditional belief that the tree should be esteemed and respected, since it was probably the home of certain saints or other spirits (Crowfoot \& Baldensperger 1932: 112).

Except for the case of $Z$. spina christi, all the other sacred trees in the Middle East are venerated for their connections with saints, prophets and other righteous figures, and not according to their taxonomic position/or mythical properties (Dafni 2006).

\section{The present-day prevalence of sacred trees in the Holy Land.}

Tewfik Canaan (1927) and S. Arráf (1993) mentioned the wide prevalence of sacred trees in the Holy Land. The former talked about 128 solitary sacred trees, while the latter surveyed 109 sites (69 of which contain one single tree and 12 include groves or forests). Armoni and Shmida (1987) surveyed about 1200 "old and veteran trees" at 100 sites in Samaria, while Lissovsky (2004) has noted 62 sacred locations containing trees in the northern part of Israel. Regarding the present survey in the northern part of Israel, I found 78 trees for which there is oral and/or written evidence concerning their "religious 
history" (Table 1). Only 33 solitary trees and four groves still serve today as centres of some kind of worship (especially the tying of votive rags).

When considering the importance of surveys of old trees and those growing in sacred places, it is important to note that not all old trees or all of those which grow in sacred places are inevitably "sacred" (defined as "targets of special worship", see Dafni 2006 and references therein). In some locations there are old trees $(n=12)$, but we have no evidence that they were the subject of any kind of worship (e.g., the largest olive trees in the Galilee, which are near the old village spring of Deir Hanna, are not worshipped at all). The need to clarify what is meant by "old" and "sacred" trees (based on written or oral evidence or field observations) complicates any attempt to compare the results of different surveys. If many trees are growing in the vicinity of a sacred place, it is impossible to consider all of them as "sacred" merely because of their specific location. When the evidence is related to a certain solitary tree (most of the sacred trees are of this type), there are usually few contradictions among the sources, but a survey of trees in "sacred places" and/or "old trees" may yield a different picture. This is especially important in studies related to botanical and ecological aspects, such as species composition and preferred habitats.

The cases of "sacred groves" in which all the trees are equally venerated prove to be extremely rare. The present survey recorded nine examples, but only three are still visited by believers today. Even in these three cases, they are visited less frequently than in the past.

In the Christian sector, tree veneration is quite rare, and individuals seldom visit sacred trees. If they do, they generally do so far away from the public eye and alone, without any public or family being present at the event.

\section{Landscape ecology and conservational aspects}

Nurit Lissovsky's (2004) and Achva Benzinberg Stein's (1987) extensive characterization of sacred trees in northern Israel as visual elements of the anthropogenic landscape led them to suggest how to preserve them from a cultural viewpoint.

All over the world sacred groves are considered as "time capsules" which may preserve the "pristine" biodiversity before human over-exploitation. There is intensive current research activity to document this biological as well as cultural diversity to provide a basis devising preservation policies, especially in India (Deb \& Malhotra 2001), Africa (Himberg 2004; Falconer 1999; Anoliefo et al. 2003; O'Neal Campbell 2005) and East Asia (Bharucha 1999; Malhotra et al. 2001; Sreedharan 2004). 
The few remaining "sacred groves" in Israel are too small to represent any distinctive protected entities in comparison with surrounding vegetation. Because of trampling, species diversity is the same as or maybe even less than in highly visited sacred groves. A. Shmida (1980) has already shown that giant sacred trees are merely a result of human protection and not any climax relics of the "old vegetation" prior to human intervention.

Sacred trees are disappearing today especially due to agriculture as well as intensive road construction, particularly if they are not situated within the villages or on private property. The deeply held and widespread belief that any harm done to a sacred tree will immediately result in divine punishment confers some protection (Canaan 1927; Arráf 1993, Dafni 2007a and references therein).

In summary, despite their beauty and charm, mighty sacred trees do not have any pure conservation value except for the aesthetic and cultural value accorded to them

Nir Beker and Shirra Freeman (2009) studied the economic value of old trees in Israel, suggesting an economic model to assess the "annual value of old growth trees". Because most of the sacred trees fall into this category, policy makers can take into consideration their importance in local heritage as a means of promoting their conservation.

\section{Conflict with religious leaders}

When I asked religious people about various aspects of tree worship, I received the following range of answers:

1. "We respect the Sheikh (to whom the tree is dedicated) and not the tree." (Bassam Hajaj, 70, Muslim, Rami, 15 June 2005)

2. "We have to believe in God, not in a tree as this is against religious law." (Qasim Bader, 45, keeper of the Druze sacred place of Nabi Sabalan, 9 June 2002)

3. "A man that prays to a tree is a heathen; we need to pray only to God. The tree is temporary; only God is eternal; we have to pray to God, who is the creator. We have to worship God, not trees." (Zaki Abu Bilal Hashad, 67, Muslim Imam, Tarshiha, 19 December 2002)

4. "A man does not need an indirect connection with God such as a sacred tree, Welli ('a saint') or any other person. It is impossible for a tree to be sacred; there is no such thing in Islam." (Sheikh Abu Tawafiq, 71, Muslim Imam, Ein Mahel, 7 November 2004)

5. "Sanctity rests only in prophets; it is forbidden to sanctify objects such as stones and trees." (Khamed Abu Mustafa, 47, Muslim, Arrabe, 21 December 2003) 
6. "People have been praying to trees since the Roman times and this remains inside the man, I believe only in one God." (Ruqqiya Maghis, 50, Bedouin, Jordeikh, 27 March 2005)

7. "In our religion (Druze) we don't sanctify people or trees, only God; we love the prophets but we don't sanctify them." Saleh Hatib, 53, Druze, Mgh'ar, 26 August 2004)

8. "A blessed tree is a symbol of the prophet not an object per se." (Akab Amashe, 45, Druze Sheikh, Buq'ata, 12 December 2001)

9. "The man (a religious figure) is sacred and the tree is blessed. The tree belongs to the people and the saints are the prophets of God. The blessed trees are monuments to special figures in the history of the Druze religion. In our religion there are no gravestones or offerings in graveyards; the trees commemorate the deeds of these special personalities." (Sheikh Shahin Hussein, 70, Druze religious leader, Beit Jan, 12 September 2000)

The following story illustrates the negative attitude of religious leaders to tree worship:

One day, a "good man" was very upset to see that people were praying to a sacred tree instead of to God, and he decided to cut it down. When he was ready with an axe in his hand, an "evil man" appeared and demanded that he not harm the tree. They had a quarrel and the "good man" won and he was determined to cut it down. Then the "evil man" convinced him not to touch the tree and promised him that every morning from then on he would find a golden coin under his pillow. For several days it was thus, but one morning there was nothing under the pillow. The "good man" was very angry about the breaking of the agreement and approached the "evil man". They quarrelled again and, on this occasion, the latter prevailed. Then the "good man" asked the "evil man": "Why is it that I prevailed the first time, and that you prevailed on the second occasion?" The answer he received was this: "The first time you came to me, it was in the name of God, but the second time was for the sake of money."

(I have heard this story, with some variations, e.g., the "evil man" was Satan himself, from several sources $(n=8)$ among both Druze and Muslims).

Religious leaders, from all the surveyed ethnic groups, are unequivocally against any manifestation of tree worship. Despite their attitude, the practice is still quite popular, albeit less so today than in previous centuries. In the present study $100 \%$ of our informants were aware of the existence of sacred trees and 
no fewer than $17 \%$ of the Druze and $7 \%$ of the Muslims have visited a sacred tree at least once.

In some places, such as in the villages Sakh'nin, Arra'be and Mesh'hed, religious leaders tried in the 1960 s to forbid visits to sacred trees, but the ban succeeded for only for a short time because of strong faith in the miraculous powers of the saints linked to the trees.

For many of the previous centuries the villages were quite isolated and without official religious leaders (Imams) and without mosques. The centres of religious life were Makams, 'the shrines of saints' (Frazer 1923: passim; Canaan 1927: passim; Arráf 1993: passim; Benzinberg Stein 1978: 123). The "holiness" spread also into the trees which became sacred, especially near the graves of saints, even without a Makam (Canaan 1927; Arráf 1993; Dafni 2006). In the absence of Makams, sacred trees replaced their religious and ceremonial function. I suspect that the decline of tree worship among Muslims in the Holy Land is related to the decrease in the popular worship of saints' shrines. From the beginning of the 20th century, official leaders established and maintained Islamic religious life even in remote villages, and oversaw the erection of mosques. As a result, the veneration of sacred trees gradually declined. Most informants recorded that their parents or grandparents had visited sacred trees regularly but it is "uncommon today". When I asked directly why the sacred trees are no longer visited 11 informants mentioned that "it is forbidden", but they gave no further explanations. However, among Druze communities, there is no similar tendency, and visits to sacred trees are still quite common.

\section{Sacred trees and syncretism}

All religions venerated the "Oak of Mamre", which has served as an important pilgrimage destination for religious Jews, Christians and Muslims throughout history (Frazer 1923: passim; see also Hepper \& Gibson's 1994 review). Almost all accounts of pilgrimages or visits to the Holy Land since the fourth century of the last millennium mention this tree. Lewis Bayles Paton (1920: 58) gives another example: "At Banyas, near the source of the Jordan, there is an ancient holy oak sacred to Sheikh Ibrahim. This is visited by members of all the sects", and these words still hold true today. In Southern Lebanon, at Nebi Khiskin, there is a Druze Khilwe (a prayer house), which contains a sacred large oak (Quercus calliprinos). The grave of a Muslim Sheikh is attached to the Khilwe and he was buried there because the Druze highly appreciated his contribution to the upkeep of the place, especially his care of the sacred tree. Shiite Muslims, who live in the area, also venerate the tree. Victoria de Bun- 
sen (1910: 241) wrote about the famous sacred Pistacia atlantica tree in Tel El Qadi (a gigantic tree, which was destroyed by fire in the late 1970s) which was a centre of pilgrimage for Christians, Jews, and Arabs. Syncretism as related to sacred trees is well known in many other countries (Frazer 1923: passim; Fowden 2002; Roy Burman 1998), and thus, is not a local phenomenon, as is clear from Tables $2 \& 3$. One of the most famous regional cases of syncretism is that of the Biblical Ashera and tree worship in the ancient Semitic race (Curtiss 1902: passim; Frazer 1923: passim; James 1966: passim; Day 1986: 392).

Today (Table 1), some sacred trees are visited mainly by local people of one specific ethnic group, while other trees $(n=7)$ are famous for their omnipotent, miraculous powers, and are visited by Muslims, Druze and, more rarely, by Christians and Jews.

The reputations of some sacred trees attract frequent visits by people from other villages, while others remain almost anonymous. In the centre of the village of Mgh'ar (which has a mixed Druze-Muslim-Christian population), there is a huge Ziziphus spina-christi tree which is dedicated to a Muslim saint (Sheihk Rabbis). The tree receives equal veneration from Druze, Muslims and Christians. By contrast, an equally large tree of the same species, in the village of Maz'ra'a, dedicated to Sheikh Radwan, is visited mainly by Muslims. Perhaps this discrepancy is due to the magnitude of the importance attributed to the related saints. Canaan (1927: passim) notes that some saints are more powerful in their miraculous abilities than others.

The tomb of Sheikh Abdalla is located in the middle of an olive grove near the village of Abu Snan, with the trees around the tomb regarded as sacred. The saint is a legendary Druze figure, but the place is visited by Muslims, Druze, and Christians. However, until about fifty years ago this place was considered to be a Muslim grave, and was then visited only by Muslims.

The present survey (Table 1) revealed eight trees (including abandoned ones) that are syncretic, 21 trees regarded as sacred only by the Druze ( $80 \%$ being close to very active religious structures in the middle of the villages), and $53 \%$ trees sacred to Muslims, $15 \%$ of which are at saints' Makams or graves).

Most of the reasons for the sanctification of trees and their associated beliefs and rituals are common to the ancient world as a whole and are not limited to the Middle East (Tables 2 \& 3; Dafni 2002, 2006, 2007a). These generalizations apply equally to the monotheistic religions and many of the current polytheistic religions as well, mainly in Asia and Africa. The findings provide solid evidence for syncretism and may serve as evidence for the historical "leaking" of habits and customs from old forms of paganism into modern religions. 


\section{Current customs related to sacred trees}

A comparison of the customs and manners related to sacred trees in presentday Israel (Dafni 2002, 2007a; Table 3) shows the following tendencies:

1. Sacred trees are just another kind of sacred place, with all of their metaphysical as well as physical manifestations. In the Middle East sacred trees are frequently associated by Muslims with the shrines and graves of saints, but this is very rare among the Druze. The Druze adherents believe in the transmigration of souls: a person's body is a kind of clothing for the soul, and with death the soul passes to the body of a newborn child (Dana 2003: 60). The Druze followers never consider sacred trees as an abode for the souls of righteous figures, and certainly do not associate them with graves (Dafni 2006).

2. In Islam there are no ceremonies or customs specific only to sacred trees, they are only performed in relation to other sacred places such as a mosque or saint's grave.

3. The following customs were found among Muslims as well as the Druze: animal sacrifice under a tree as part of the fulfilment of a personal vow; leaving money; attaching votive rags, making personal vows, placing of objects to absorb a divine blessing (Barake), hammering nails, placing stones under the tree, burning incense, lighting candles and weddings.

4. A few customs (e.g., the settling of quarrels, known as Sulkha), leaving objects to absorb divine blessings, and leaving objects for charity, seem to be characteristic of the Middle East, and were not recorded in other regions.

5. In modern times, sacred trees were never recorded in the Middle East as centres for official religious ceremonies, including sacrifices (to appease God), nor as places for the performing of rites of passage.

6. There are some variations among different ethnic groups: the Druze practice of kissing and decorating trees with pictures of religious leaders is largely restricted to them, while burying the dead under trees, leaving water and conducting rain-making ceremonies were not recorded from this group. Bedouin communities traditionally pass judgments under trees and commonly use them as public social centres.

The Druze very rarely conduct weddings near sacred trees, but this practice is common among Muslims, especially the Bedouins.

7. Since the 1950s and 1960s, ceremonies, such as rainmaking, weddings, Sulkha, and passing judgement under sacred trees are now almost extinct. Nevertheless, they figure vividly in the memories of older people.

8. Sacred trees in cemeteries are objects of great fear and are associated with worship, but ceremonies are not performed under them and tying of votive rags is very rare. These trees are still considered to have miraculous powers, especially when harmed or dishonoured. 
9. When a sacred tree is adjacent to the tomb of a saint or to another religious structure, the main object of worship is the sacred place, and the tree is of a secondary importance.

In one case (Sheikh Saris near Majdal Kurum), there is a "sacred cabinet" (a domestic plastic cupboard) under the tree, which contains prayer books, money, rosary beads, candles, matches, incense and oil. In the last decade it has been replaced at least twice, because of fires caused by candles lit by worshippers. Activity under this specific tree is currently very frequent: offerings and rags placed on the tree change frequently, and remnants of family feasts are often left there. Several years ago, the tree canopy was closed into a type of a dome that created a place of deep shade, reminiscent of Pliny, who wrote that trees were the first temples of nature l.c.). Today (2010) the tree canopy is disrupted and cannot provide the seclusion and privacy that existed only four years ago.

This is the only case of which the author is aware when a sacred tree became a semi-official place of worship. There are no signs of a saint's grave near the tree and the tree is not especially large or impressive; thus it is not at all clear why it became so important and why it remains so even today. The local people $(\mathrm{n}=12)$ who visited the tree were unable to offer us any explanation as to why they visit this specific place, and only said that it is a "sacred tree".

\section{The future of the sacred trees}

Canaan (1927) and Arráf (1993) refer to many sacred trees that are unknown today. Some of these trees were neglected and disappeared because of destruction of villages in the 1948 war and as a result of extensive land development that took place later. In the present survey I documented at least 20 individual trees that have disappeared over the past fifty years.

It is difficult to pinpoint the reasons why sacred trees were neglected. Some abandoned trees still exist physically. I recorded 12 such trees which are visited very rarely; only elderly people know that these trees ever were sacred. Several such trees are in the vicinity of villages but have been disregarded by local people, especially during the last fifty years. There seems to be a general lessening of popular beliefs, including the practical worship of trees, although it is still deeply embedded in the public memory.

Some trees were more fortunate, and are carefully preserved by local authorities or by some families whose yards contain them. Most of these trees $(\mathrm{n}=8)$ are in Druze areas, and seven of them are presently within the boundaries of villages. 


\section{Muslim vs. Druze tree worship}

A comparison of the reasons, regarding sanctity attributed to trees (Table 2), reveals differences between Druze and Muslims (Arabs as well as Bedouins), reflecting the Druze belief in the transmigration of souls, mentioned above. The Druze never regard sacred trees as abodes of the souls of righteous figures and certainly do not relate them to graves (Dafni 2006). Transmigration of the soul is also the reason why graves are not regarded as important by the Druze. Thus, the two commonest reasons for the sanctification of trees found among Muslims (trees as a saint's abode and their vicinity to graves) are alien to Druze tradition. The Druze focus on the deeds and events in the life of their prophets and religious leaders. In practice, the most common manifestations of tree worship (Table 3) such as votive rag tying, vows, personal petitions and praying, are almost as frequent among the Druze and the Muslims, tree worship is clearly more popular among the Druze than Muslims (Dafni 2002; Dafni et al. 2005). It was therefore unexpected to find that even the Druze relate supernatural powers to sacred trees; their fear of and admiration for sacred trees is equal to that of the Muslims (Table 3; Dafni 2002, 2006, 2007a, 2007b).While the Muslims ascribe miraculous powers (e.g., the trees' immunity to fire) to Wellis' souls or God, the Druze ascribe them to the prophet or religious leaders (Dafni 2006). In this specific point the Druze religion is closer to the Jewish faith than that of the Muslims.

According to the Druze religion, there are two "classes" of people, religious ones and non-believers, and there is no intermediate phase (Dana 2003). Religious people are very orthodox and strictly avoid any manifestation of tree worship; their centre for praying is an official place (Khilwe). Non-believers among the Druze have only vague ideas about the secrets of their religion and are not allowed to enter the Khilwe; actually, they have nowhere to practice their religion. It seems that the higher prevalence of "active" sacred trees in Druze areas compared with that of Muslims (Table 1) arises from the needs of the secular Druze for a place for fulfilment of their personal spiritual needs. Most of the Druze sacred trees are dedicated to their prophets (Dafni 2006) and thus may freely replace the religious function of the Khilwe without the intervention of religious authority.

\section{Sacred trees among the Jews}

The Israeli Ministry of Religious Affairs has adopted many traditional sacred grave sites of local saints since the foundation of the State of Israel (1948). These were officially declared to be tombs of historical Jewish righteous peo- 
ple, some of which include very famous sacred trees. New tombs were erected in such places, replacing old ones. Some of these sites $(n=4)$ became places of devotion for Jewish believers and this type of pilgrimage is now popular, but the tomb is the focus of devotion rather than the tree. These trees, formerly very famous and popular among local people, are less visited by Muslims and the Druze today, if at all. Some of the other sacred trees are syncretic and visited, infrequently, also by Jews. Other trees in the vicinity of graves of Jewish righteous figures or Jewish cemeteries are visited and used also as "wishing trees" and are never treated as sacred objects, and all prayers and votive offerings are directed only to the specific religious figure.

At Kadita, Upper Galilee, there is a large tree near the gravestone of Rabbi Tarfon. A cabinet constructed in 2006 stands under the tree and contains prayer books and a permanently lit glass oil lamp. Muslims used to venerate this site but now ignore it after the grave became popular with Jewish believers. A Ziziphus spina christi tree at the old Jewish cemetery of Tiberias is close to the graves of four famous rabbis. Visitors used to pick fruits from the tree as talismans for long life, and according to the evidence of the local keeper of the place: "My family is eight generations in Tiberias and it is a tradition that passed from generation to generation that we are not allowed to touch or to cut this tree. The Jews pick fruits as a health talisman." (Akhikam Moshe David 4.5.2009, www.nrg.co.il)

The tree near the Tomb of Rabbi Uziel Ben Yonatan (in Amuka, Upper Galilee) is covered with rags and written personal requests. This rabbi is revered as a match-maker, and the site has recently become a centre of mass pilgrimage by single girls specifically for this purpose. After praying at the tomb, many used to visit the tree and leave a reminder to the righteous person although it was forbidden by the local religious authorities.

In the old cemetery of Safed people used to leave rags and other objects on trees near sacred graves. Additionally, they walked around a specific grave seven times while chanting a prayer for health and a good life, and then put rags or notes on the tree. One of the duties of the local keeper is to remove rags from the trees. According to the words of the local researcher and guard of the place: "It is not a Jewish manner... people from North Africa have copied Islamic traditions." (Elyahu Ben Tovim 12.10.09) I was unable to find any Jewish sacred trees which are not attached to a sacred grave or Jewish cemetery. Interestingly, sacred trees in Muslim cemeteries are highly respected but rarely serve as targets for a personal petition. 


\section{Monotheistic vs. polytheistic sacred trees}

Today in the Middle East, as well as in Europe, individuals submit personal petitions as part of tree worship. However, the sanctification of trees is not part of any major monotheistic religion (Dafni 2006). In Muslim, Druze and Christian traditions, sacred trees are dedicated to saints and prophets who guard their trees and punish anyone who tries to harm them, targeting the offender and/or his family and property and not the whole community. These religions have no official codes of punishment to protect sacred trees or groves from deliberate violation (Dafni 2007a).

Most polytheistic religions prevail in regions dominated by tropical or semitropical vegetation. Here, the sacred wood/grove/forest is the focus of worship and a centre of well established religious ceremonies, sometimes led by official figures.

Until recently, the wood/forest/grove was regarded as essential to protect the culture's very existence, as, for example, sources of medicinal plants and watersheds. Systems of punishment were established to protect the woodland resources from over-exploitation. Society regards any wilful harm to trees as direct sacrilege against the supernatural power who is the benefactor of the community and may punish the whole community in revenge. This might take the form of frequent suffering which could include calamities such as fire, flood, or disease. Thus, there is a need to pacify the supernatural powers, who guard the community and to whom the trees are dedicated. This putative pattern has been recorded fully or partly in Vietnam (Wode 2002: 113), Kenya (Himberg 2004: 89), Mozambique (Serra 2001: 14), Laos (Chanthitath 2000: 324), China (Laird 1991: 352; Huabin 2003: 131-132), India (Amirthalingam 2000: 8; Rodgers 1994: 345; Khiewtam \& Ramkrishnan 1989: 66-68; ApffelMarglin \& Mishra 1993: 201; Patnaik \& Pandey 1998: 315-319; Bharucha 1991: 384; Dudley 1999: 96), East Africa (Hobley 1967: 414, 432), Cote D’Ivoire (Zoundjihekpon \& Dossou-Glehouenou 1991: 370), Nigeria (Anoliefo et al. 2003: 290, 292-293), Ghana (Falconer 1991: 366; O’Neal-Campbell 2005: 159), Timor (McWilliam 2001: 90-99), Senegal, Vietnam (Boven \& Morohashi 2002: 113).

Comparison of the reasons why trees/groves become sacred shows some dichotomy between the monotheistic legacy of the sacred trees in Europe, Middle East and North Africa in comparison with the polytheistic traditions elsewhere (Dafni 2006).

In polytheistic religions, especially in Africa and Asia, people still see the sacred tree/grove as the abode of deities or their ancestors' spirits (Table 1), which may reflect the old pagan habits that prevailed in the distant past in Europe, the Middle East as well as North Africa. 
In the polytheistic world the sacred tree is a centre of communal tribal activities and sometimes access is limited to only certain people and/or on certain occasions, the grove being maintained by the community or by a special priest. Furthermore, there is a general taboo against harming the tree in Sierra Leone (Lebbie \& Freudenberger 1996: 311), Okinawa (Sered 1999: 518), East Timor (Meitzner-Yoder 2005: 224), India (Sreedharan 2004: 49; Malhotra et al.2001: 9), Russia (Vovina 2000: 699), Zimbabwe (Chidhakwa 2001: 6), Northern Ghana (Millar et al. 1999: 35), Vanuatu (Thaman 1992: 9), Mozambique (Virtanen 2002: 229), West Africa (McKenzie 1997: 45). In the Middle East, the sacred tree is regarded today as a centre for individual ritual behaviour with free access for anybody (Canaan 1927; Dafni 2007b).

\section{Tree worship in the Muslim world}

Several authors consider tree worship in the Muslim world as a relic of old pagan ideas of tree-spirits or gods, which survived, in a barely disguised form, throughout the ages of Christian and Islamic supremacy (Thompson 1883: 242; Robertson-Smith 1889: 199; Frazer 1923: 50). The tree spirits/deities/gods of the early pagan inhabitants were replaced after the Arab conquest by the spirits of the Muslim saints, the Awliya, who may live and appear in the sacred tree, e.g., in Palestine (Canaan 1927: 151), Iran (Ouseley 1819: 378) and Morocco (Westermarck 1973: 97). A completely different view is expressed by William F. Albright (1940: 284-286) who considers the Welli cult of Palestine and Syria as merely a phase in the cult of the saints of the Mediterranean region and to differ only in the finer details from the cult of the lower classes in other Mediterranean lands. Moreover, Albright argues that this saint-cult goes back to the Christian saint-cult of the Eastern Roman Empire in early Byzantine centuries and is Hellenistic-Roman, not Semitic in origin. Along the same lines, G. D. Hornblower (1930: 19) noted, concerning the sacred trees in Egypt, that the local gods were replaced by local saints, first Christian and then Mus$\lim$

With the further evolution of Islam, these old venerated trees were cut down and this kind of worship was strictly forbidden (Goldziher 1971: 318). The practical result, which, can be seen today, could be considered as a kind of functional religious replacement: the trees were no longer regarded as abodes of tree-spirits, deities or gods as they had been in earlier heathen times, but as the abodes of saints, regarded as the messengers of God himself. This kind of "soft idolatry" is in existence even today, despite formal Islamic directives, which are not strong enough to eliminate it, especially in rural areas. 
In summary, as a result of the present study, tree worship is still alive in present-day Israel, although there has been a considerable decline over the last few decades. I fully agree with James G. Frazer (1923: 43), who wittily summarized the status of the sacred trees in the Middle East as follows: "Thus the worship at the high places and green trees, which pious Hebrew kings forbade and prophets thundered against thousands of years ago, persists apparently in the same places to this day."

\section{CONCLUDING REMARKS}

Tree veneration is especially popular in the Druze villages as well as in rural Muslim areas. It is less common among the Bedouins and rare in the mostly urban Christian-Arab societies, but has shown recent growth among the Jews.

While the Muslims connect sacred trees with the souls of saints and their graves, the Druze, who believe in transmigration of souls, relate blessed trees mainly to events and activities in the lives of prophets and historical religious leaders. Most of the customs, attitudes and manners related to sacred trees and reasons for sanctification are syncretic but some are restricted to the Druze.

Because of the pace of modern life, and land development, we are witnessing the erosion of traditions and sacred trees and their veneration are now in a steady decline. Most are now solitary and not in old groves; they have an importance as objects of cultural heritage rather than any iconic value for the conservation of pristine habitats and survive thanks to religious sanctions against their destruction.

\section{ACKNOWLEDGEMENTS}

I would like to thank Peter Raven, Donald J. Hughes, Peter Bernhardt, David Firmage, John McMahon, and Idith Pintel-Ginsberg for their comments and encouragement. Special thank to Shay Levi for all his invaluable technical and moral support. 


\section{REFERENCES}

Akhikam, Moshe David 4.5.2009. Maariv newspaper website www.nrg.co.il, last accessed on 1. August 2011.

Albright, William F. 1940. Islam and the Religions of the Ancient Orient. Journal of the American Oriental Society, Vol. 60, No. 3, pp. 283-301.

Amirthalingam, M. 2000. Folklore of Sacred Groves. Indian Folklife, Vol. 1, No. 3, pp. 8-9. http://www.wiki.indianfolklore.org/images/e/e1/IFL_03.pdf, last accessed on 30 July 2011.

Anabsi, Ghalib 2008. Popular Beliefs as Reflected in 'Merits of Palestine and Syria' (Fa-il al-Shm) Literature: Pilgrimage Ceremonies and Customs in the Mamluk and Ottoman Periods. Journal of Islamic Studies, Vol. 19, No. 1, pp. 59-70.

Anoliefo, G. O. \& Isikhuemhen, O. S. \& Ochije, N. R. 2003. Environmental Implications of the Erosion of Cultural Taboo and Practices in Awka-South Local Governmental Area of Anambra State, Nigeria: 1. Forests, Trees and Water Resource Preservation. Journal of Agricultural and Environmental Ethics, Vol. 16, No. 3, pp. 281-296.

Apffel-Marglin, Frederique \& Mishra, Purna Chandra 1993. Sacred Groves: Regenerating the Body, the Land, the Community. In: W. Sachs (ed.) Global Ecology: A New Arena of Political Conflict. London: Zed.

Armoni, H. \& Shmida A. 1987. Seker etsim kdoshim bashomron hamerkazi uve'eretz Binyamin. [Survey of the Old Trees of Central Samaria and the Land of Binyamin.] Rotem, Vol. 22, pp. 27-56. (In Hebrew).

Arráf, S. 1993. Tabkat el - elnabiya wa'ulaya wa'altsalkhin fi alrd almukadasa. [The Status of the Prophets and Saints in the Holy Land.] Tarshikha: Ikhwan Mahul. (In Arabic).

Beker, Nir \& Freeman, Shirra 2009. The Economic Value of Old Growth Trees in Israel. Forest Policy and Economics, Vol. 11, pp. 608-615.

Benzinberg Stein, Achva 1987. Landscape Elements of the Makam: Sacred Places of Israel. Landscape Journal, Vol. 6, No. 2, pp. 123-131.

Besterman, Theodore 1928. The Belief in Rebirth of the Druses and Other Syrian sects. Folklore, Vol. 39, No. 2, pp. 133-148.

Bharucha, Erach 1999. Cultural and Spiritual Values Related to the Conservation of Biodiversity in Sacred Groves of the Western Ghat in Maharashtra. In: D. A. Posey (ed.) Cultural and Spiritual Values of Biodiversity: A Complementary Contribution to the Global Biodiversity Assessment. London \& Nairobi: Intermediate Technology Publications \& United Nations Environment Programme, pp. 382385 .

Boven, Karin \& Morohashi, Jun 2002. Best Practices Using Indigenous Knowledge. The Hague: Nuffic \& UNESCO/MOST.

Canaan, Tewfik 1927. Mohammedan Saints and Sanctuaries in Palestine. Jerusalem: Ariel. 
Chandran, M. D. Subash \& Hughes, J. Donald 1997. The Sacred Groves of South India: Ecology, Traditional Communities and Religious Change. Social Compass, Vol. 44 , No. 3, pp. 413-427.

Chanthirath, Khampa 2000. Forest Utilization by Local People in Vang Vieng District. Forest Conservation and Afforestation Project (FORCAP). Kanagawa: the Institute for Global Environmental Strategy. http://enviroscope.iges.or.jp/modules/ envirolib/upload/1504/attach/ir98-3-25.pdf, last accessed on 30 July 2011.

Chidhakwa, Zvidzai 2001. Continuity and Change: The role and dynamics of traditional institutions in the management of the Haroni and Rusitu forests in Chimanimani, Zimbabwe. Paper presented at the Centre for Applied Social Sciences/PLAAS CBRNM 3rd Regional Workshop, Maputo, Mozambique.

Crowfoot, Grace M. \& Baldensperger, Louise 1932. From Cedar to Hyssop: A Study in the Folklore of Plants in Palestine. London: The Sheldon Press.

Culmsee, Heike \& Deil, Ulrich \& Berriane, Mohamed 2005. Sacred groves in Morocco: A society's conservation of nature for spiritual reasons. Silva Carelica, Vol. 49, pp. 185-201.

Curtiss, Samuel Ives 1902. Primitive Semitic Religion To-Day: Record of Researches, Discoveries and Studies in Syria, Palestine and the Sinaitic Peninsula. London: Hodder and Stoughton.

Dafni, Amots 2002. Why Are Rags Tied to the Sacred Trees of the Holy Land? Economic Botany, Vol. 56, No. 4, pp. 315-327.

Dafni, Amots 2006. On the Typology and the Worship Status of Sacred Trees with a Special Reference to the Middle East. Journal of Ethnobiology and Ethnomedicine, Vol. 2, pp. 26.

Dafni, Amots 2007a. The Supernatural Characters and Powers of Sacred Trees in the Holy Land. Journal of Ethnobiology and Ethnomedicine, Vol. 3, No. 10.

Dafni, Amots 2007b. Rituals, Ceremonies and Customs Related to Sacred Trees with a Special Reference to the Middle East. Journal of Ethnobiology and Ethnomedicine, Vol. 3, p. 28.

Dafni, Amots \& Levy, Shay \& Lev, Efraim 2005. The Ethnobotany of Christ's Thorn Jujube (Ziziphus spina christi) in Israel. Journal of Ethnobiology and Ethnomedicine, Vol. 1, No. 8.

Dana, Nissim 2003. The Druze in the Middle East:Their Faith, Leadership, Identity and Status. Brighton \& Portland: Sussex Academic Press.

Day, John 1986. Asherah in the Hebrew Bible and Northeast Semitic Literature. Journal of Biblical Literature, Vol. 105, pp. 385-408.

De Bunsen, Victoria 1910. The Soul of a Turk. London: John Lane.

Deb, Debal \& Malhotra, K. C. 2001. Conservation Ethos in Local Traditions: The West Bengal Heritage. Society \& Natural Resources: An International Journal, Vol. 14, Issue 8, pp. 711-724.

Dudley, Ann M. 1999. Indigenous Forest Use Practices and Sustainability: A Case of the Adivasis of the Nilgiri Biosphere Region, South India. Unpublished M.A. thesis. Halifax, Canada: Saint Mary's University.

Eliade, Mircea 1958. Patterns in Comparative Religion. London: Sheed \& Ward. 
Elyahu, Ben Tovim 12.10.2009. Personal communication.

Falconer, Julia 1999. Non-Timber Forest Products in Southern Ghana:Traditional and Cultural Forest Values. In: D. A. Posey (ed.) Cultural and Spiritual Values of Biodiversity - A Complementary Contribution to the Global Biodiversity Assessment. London \& Nairobi: Intermediate Technology Publications \& United Nations Environment Programme.

Fowden, Elizabeth Key 2002. Sharing Holy Places. Common Knowledge, Vol. 8, No. 1, pp.124-146.

Frazer, James George 1923. Folklore in the Old Testament. New York: Tudor Publishing Company.

Frese, Pamela R. \& Gray, S. J. M. 1995. Trees. In: M. Eliade (ed.) The Encyclopaedia of Religion. Vol. 15. New York: Macmillan, pp. 26-33.

Goldziher, Ignaz 1971. Muslim Studies. Edited by S. M. Stern. London: George Allen \& Unwin.

Hamilton, Lawrence S. 2002. Forest and Tree Conservation through Metaphysical Constraints. The George Wright Forum, Vol. 19, No. 3, pp. 57-78.

Hepper, F. Nigel \& Gibson, Shimon 1994. Abraham's Oak of Mamre: The Story of a Venerable Tree. Palestine Exploration Quarterly, Vol. 126, No. 2, pp. 94-105.

Himberg, Nina 2004. Community-based Ecotourism as a Sustainable Development Option in Taita Taveta, Kenya. In: P. Pellikka \& J. Ylhäisi \& B. Clark (eds.) Taita Hills and Kenya, 2004 - Seminar, Reports and Journal of a Field Excursion to Kenya. Expedition Reports of the Department of Geography, University of Helsinki 40, pp, 39-46. Helsinki.

James, E. O. 1966. The Tree of Life: An Archaeological Study. Leiden: E. J. Brill.

Khiewtam, Ramesh S. \& Ramkrishnan, P. S. 1989. Socio-cultural Studies of the Sacred Groves of Cherrapunji and Adjoining Areas in North-Eastern India. Man in India, Vol. 69, pp. 64-71.

Hobley, Charles W. 1967. Bantu Beliefs and Magic. London: Frank Cass.

Hornblower, G. D. 1930. A Sacred Grove in Egypt. Man, Vol. 30, pp. 17-19.

Huabin, Hu 2003. Sacred Natural Sites in Xishuangbanna, South-Western China. In: C. Lee \& T. Schaaf (eds.) The Importance of Sacred Natural Sites for Biodiversity Conservation. Proceedings of the International Workshop held in Kunming and Xishuangbanna Biosphere Reserve, People's Republic of China, 17-20 February 2003. Paris: UNESCO \& MAB \& CAS \& LINKS \& IUCN. http:// unesdoc.unesco.org/images/0013/001333/133358e.pdf, last accessed on 30 July 2011.

Laird, Sarah A. 1999. Forests, Culture and Conservation. In: D. A. Posey (ed.) Cultural and Spiritual Values of Biodiversity. London: Intermediate Technology Publications \& UNEP.

Lebbie, Aiah Randolph \& Freudenberger, Mark Schoonmaker 1996. Sacred Groves in Africa: Forest Patches in Transition. In: J. Schelhas \& R. Greenberg (eds.) Forest Patches in Tropical Landscape. Washington: Island Press.

Lissovsky, Nurit 2004. Al ha'etzim ve'al hamakom - meafienim tarbutyyim, tiv'yyim vekhazutyyim shel hanof hamekudash be'Eretz Israel. [On Trees and "the 
Place": Cultural, Natural and Visual Characteristics of the Sacred Landscape in Israel.] Cathedra, Vol. 111, pp. 47-74. (In Hebrew).

Malhotra, Kailash C. \& Chaterjee, Studipto \& Gokhale, Yogesh \& Srivastava, Sanjeev 2001. Cultural and Ecological Dimensions of Sacred Groves in India. New Delhi: Indian National Science Academy.

McKenzie, Peter Rutherford 1997. Hail Orisha! A Phenomenology of a West African Religion in the Mid-Nineteenth Century. Leiden: Brill.

McWilliam Andrew 2001. Prospects for the Sacred Grove, Valuing Lulic Forests of Timor. The Asia Pacific Journal of Anthropology, Vol. 2, No. 2, pp. 89-113.

Medzini, A. 1984. Expansion of Bedouin Settlement in Galilee Resulting from Spontaneous Occupation and Planned Government Policy. Monogeography, Vol. 1. Haifa: Department of Geography, University of Haifa.

Meitzner-Yoder, Laura Suzanne 2005. Custom, Codification, Collaboration: Integrating the Legacies of Land and Forest Authorities in Oecusse Enclave, East Timor. Doctoral dissertation. Faculty of Graduate School. Yale University.

Millar, David \& Aniah, Richard \& Atoyure, Peter 1999. Shrines and Groves. COMPAS Newsletter-October 1999, pp. 32-36. http://www.compasnet.org/blog/wp-content/ uploads/2011/03/CM/CM2.pdf, last accessed on 30 July 2011.

Mills, John 1864. Three Months' Residence at Nablus and an Account of the Modern Samaritans. London: J. Murray

O’Neal Campbell, Michael 2005. Sacred Groves for Forest Conservation in Ghana's Coastal Savannas: Assessing Ecological and Social Dimensions. Singapore Journal of Tropical Geography, Vol. 26, pp. 151-169.

Ouseley, William 1819. Travels in Various Countries of the East (1810-1812). Vol.1. London: Rodwell \& Martin.

Patnaik, S. \& Pandey, A. 1998. A Study of Indigenous Community-based Forest Management System: Sarana (Sacred Grove). In: P. S. Ramakrishnan, K. G. Saxena, U. M. Chandrashekara (eds.) Conserving the Sacred for Biodiversity Management. Delhi: Oxford \& IBH Publishing Co.

Paton, Lewis Bayles 1920. Survivals of Primitive Religion in Modern Palestine. The Annual of the American School of Oriental Research in Jerusalem, Vol. 1, pp. 5165.

Philpot, J. H. 1897. The Sacred Tree or the Tree in Religion and Myth. London: MacMillan.

Pliny 1945. Natural History (transl. by H. Rackham). London \& Cambridge, Massachusetts: Harvard University Press, Loeb Classical Library.

Porteous, Alexander 1928. Forest Folklore, Mythology and Romance. London: George Allen \& Unwin Ltd.

Quantz, J. O. 1898. Dendro-psychosis. American Journal of Psychology, Vol. 9, No. 4, pp. 449-506.

Robertson-Smith, William 1889. Lectures on the Religion of the Semites. Edinburgh: Adam \& Charles Black.

Rodgers, W. A. 1994. The Sacred Groves of Meghalaya. Man in India, Vol. 74, pp. 339348. 
Rodwell, John Meadows (transl.) 1937. The Koran (introd. By G. Margolioth). London: J. M. Dent.

Roy Burman, J. J. 1998. Syncretic Sacred Groves and Forests. The Eastern Anthropologist, Vol. 51, pp. 373-381.

Sered, Susan 1999. Women of the Screed Groves: Divine Priestesses of Okinawa. Oxford: Oxford University Press.

Serra, Antonio 2001. Legitimacy of Local Institutions for Natural Resource Management: The Case of M'Punga, Mozambique. Marena Research Project, Working Paper No. 3. School of African and Asian Studies, University of Sussex \& Centro de Experimentação Florestal, Sussundenga, Mozambique. http:// www.geog.sussex.ac.uk/research/development/marena/pdf/wp3.pdf, last accessed on 30 July 2011.

Shmida A. 1980. Al be'ayat hakhoresh vehaya'ar shel ha'alon hamatsuy be'eretz Israel. [On the Problems of the Maquis and Forests of Quercus calliprinos.] Teva Va'Aretz, Vol. 22, pp. 52-57. (In Hebrew)

Simoons, Frederick J. 1988. Plants of Life, Plants of Death. Madison: University of Wisconsin Press.

Sreedharan, T. P. 2004. Biological Diversity of Kerala: A Survey of Kalliasseri Panchayat, Kannur District. Discussion Paper No. 62. Thiruvananthapuram: Kerala Research Programme on Local Level Development, Centre for Development Studies. http://www.scribd.com/doc/47019627/62, last accessed on 30 July 2011.

Subtelny, Maria Eva 1989. The Cult of Holy Places: Religious Practices among Soviet Muslims. Middle East Journal, Vol. 43, No. 4, pp. 593-604.

Thaman, R. R. 1992. Batiri Kei Baravi: The Ethnobotany of Pacific Island Coastal Plants. Atoll Research Bulletin, Vol. 361, pp. 1-62

Thompson, William McClure 1883. The Land and the Book; or, Biblical Illustrations Drawn from the Manners and Customs, the Scenes and Scenery, of the Holy Land. London: Nelson.

Virtanen, Pekka 2002. The Role of Customary Institutions in the Conservation of Biodiversity: Sacred Forests in Mozambique. Environmental Values, Vol. 11, pp. 227-241.

Vovina, P. Olessia 2000. Building the Road to the Temple: Religion and National Revival in the Chuvash Republic. Nationalities Papers, Vol. 28, No. 4, pp. 695-706.

Westermarck, Edvard Alexander 1968. Ritual and Belief in Morocco. New York: University Books.

Westermarck, Edvard Alexander 1973. Pagan Survivals in Mohammedans Civilisation. Amsterdam: Philo Press.

Wode, Björn 2002. Village Forest Protection Regulations in Vietnam: Strengthening Participation in Natural Resource Management. In: K. Boven \& J. Morohashi (eds.) Best Practices Using Indigenous Knowledge. Hague: Nuffic \& UNESCO, pp. 112-129.

Zahan, Dominique 1979. The Religion, Spirituality and Thought of Traditional Africa. Chicago: Chicago University Press. 
Zoundjihekpon, Jeanne \& Dossou-Glehouenou, Bernadette 1991. Cultural and Spiritual Values of Biodiversity in West Africa: the Case of Benin and Côte d'Ivoire. In: D. A. Posey (ed.) Cultural and Spiritual Values of Biodiversity:A Complementary Contribution to the Global Biodiversity Assessment. London \& Nairobi: Intermediate Technology Publications \& United Nations Environment Programme. Zwemer, Samuel Marinus 1920. The Influence of Animism in Islam. London: MacMillan. 


\title{
CHAOTIC IDENTITIES, LOVE AND FATHERING
}

\author{
Stephen Williams
}

\begin{abstract}
Fathers today are confronted with constantly changing ideas on their role as a parent. The old traditional forms of fathering i.e. the breadwinner and protector roles are being gradually replaced by a more reflexive role that places unconditional love from their children as a central theme in a new type of reflexive parenting. This article examines the role of fatherhood through the theoretical lens of reflexive modernity. It recognises that men are increasingly becoming dependant on their children for unconditional love and this is forcing men to become more involved in the lives of their own children. The theory of reflexive modernisation is applied to a group of 40 fathers from a post-industrial area of Britain to unravel the processes and practices being used in this "new" type of parenting. This research discovers that fathers in the 21st century have numerous pressures from changing ideas about what is a good or bad father, but in the final instance it is their individualised responses to these societal and personal circumstances which create a new reflexive type of fathering. This type of fathering is therefore created by general social changes within a reflexive modern society and also by personal choice.
\end{abstract}

Key words: change, de-traditionalisation, fatherhood, love, reflexivity

In contemporary society we are confronted with such an array of conflicting social imagery that, as individuals, it is sometimes difficult to understand what is required in any particular role. This is why some academics argue that roles, duties and correspondingly social identities are becoming fragmented and diversified in the late modern age (Beck et al. 1994; Lupton \& Barclay 1997; Bauman 2000, 2001; Beck \& Beck-Gernsheim 2002). In all social areas the one-time universal formation of "modern" traditional certainties such as family, motherhood and fatherhood are now disparate and subverted (Doherty 1997; Silva \& Smart 1999). Traditional identities, traditional cultures and traditional institutions, such as the family, have become altered to an extent that they have become virtually unrecognisable from what preceded them. However, as with most sociological ideas this is a contested concept, especially when it is to do with notions such as gender, class or even masculinities as arguments rage as to whether such transformations can overcome rigid normative assumptions (Morgan 1996; Beynon 2002). Indeed, within the debates 
concerning the alteration of the institution of the family, particularly the roles played out within this social space, it is disputed whether the actual allocation of new duties to these gendered roles can overcome old rigid "norms".

To develop this into one research question, can the strength of the patriarchal gendered order with its normative assumptions resist social change? In fact, Michael Bittman et al. (2003) state that arguments concerning role changes within households, which are supposedly driven by what they call "exchange theory" with women expecting help with the household chores in exchange for bringing money into the household is questionable. They argue that this can be subverted by the normative ideologies behind gender with all its stereotypes. In other words, and to paraphrase the title of Bittman et al., role changes will eventually be trumped by monolithic stereotypes concerning gender "norms" and rather than a recreation of new roles we have a continuation with "normative" gender roles which will proceed infinitum. Indeed, when looking at traditional family roles such as fatherhood, Esther Dermott (2003) argues that while there may be a "demise of the breadwinning father" other changes are too difficult to detect (Dermott 2003: 1). Nevertheless if we as social scientists want to detect these changes we should look at the "new" individual relationship between father and child, rather than solely looking for changes in larger universal concepts such as gender roles, because these can themselves be vague and ambiguous. Individual changes in behaviour appear to be easier to detect than "structural" change. Slightly earlier David Morgan (1999) argued that the gendered order is maintained or dismantled with regard to what is done in practice around the household, and therefore looking at what men/fathers did "in practice" was the best indicator of any form of social change.

Drawing on these ideas and browsing through the catalogue of academic literature which is now being published on fatherhood, we find similar dilemmas and questions concerning these new roles (Hawkins \& Dollahite 1997; Dienhart 1998; Dermott 2003, 2008; Williams 2008). These are directly related to the following questions: What is a father? Is there more than one type of fatherhood? Has fathering changed and if it has changed what has caused this change? All are practically impossible to answer without a full understanding of the processes involved in shaping our lives in late modernity. To fully understand these processes this paper attempts to explain how fathering has become altered by being at the crossroads of conflict over societal and personal change. Using concepts like reflexive modernisation, individualisation, choice and determinism it shows that fathering is being altered by personal choices, partnership conflict and what is now accepted by society in general. This is not to say that fathers are simply choosing role models from an eclectic array of choices, but rather they are faced with a set of options which determine what 
and who they are. Indeed fatherhood today is like being at an all-you-can-eat restaurant, it may be a vast menu to choose from but there are parameters and therefore limitless choice is not an option. In other words, although it may appear that there may be limitless options to choose from, in a certain way these are still structurally formed. Therefore changing roles are never simply personal choice or a structural determinant but a combination of the two. This paper aims to explain changes in fathering through the lens of reflexive modernisation. It traces how fathers are slowly changing due to a struggle between personal relationships and society's structural alterations and hence in the process they are becoming reflexive fathers (Williams 2002, 2008). This is achieved through an analysis of reflexive modernisation, particularly Ulrich Beck and Elisabeth Beck-Gernsheim's interpretation of reflexivity with the main elements being reflection (choice) and reflex (structural change), and applying these theories to qualitative interviews carried out amongst a group of fathers.

\section{METHODS}

Semi-structured interviews were used to provide the research with a rich vein of information on individualised fathering. The interviews took place in the post-industrial South Wales valleys and the city of Cardiff. The fathers were asked to explain their lives as fathers and they did this with incredible frankness and warmth. The sample frame was made-up of 40 fathers evenly divided into four subsections to roughly represent the socio-economic spectrum of late modern life. Indeed, although the findings in this paper give us an in-depth understanding of this sample of fathers, more general observations on fatherhood could be misleading because of the small scale of the sample. However, these subsections were divided as follows:

1. Professional fathers

2. Employed fathers

3. Unemployed fathers

4. Student fathers

Professional fathers were categorised as working in a recognised profession, such as teachers and lecturers. The employed subsection included any father working in a non-professional job, and not included in any other subdivision. Unemployed fathers were the long-term unemployed who had been on benefits for more than six months. The student fathers were made-up of men who had left full-time employment and entered university as full-time students. All 
categories were needed to trace the chaotic formation of reflexive fathering in the 21 st century.

It has been argued that the relationship between parents and children is in the midst of change, as parental authority over children is becoming less authoritarian and more negotiated (Giddens 1990; Jamieson \& Toynbee 1990; Beck \& Beck-Gernsheim 2002; Williams \& Williams 2005). Indeed, research undertaken by a team at Lancaster University investigated the late modern view that families are becoming less authoritarian and more democratic. Jo Warin et al. (1999) investigated the parent-child relationship in relation to perceived ideas on the democratisation of family life and a demand, by government, for a reversal to more parental control and moral authority over young people. They concluded, in relation to fathering, that some fathers portrayed themselves as those who "discipline" whilst the mothers, on the other hand, "negotiated" and "talked" to their children. Conversely, they also argue that other fathers were frequently reluctant to act as disciplinarians and criticised government policy that made parental authority replicate increasingly outdated roles. In fact, they argue that policy makers need to listen to parents and draw on their experience, instead of making policies based on mythical idealised roles.

Gill Valentine (1999) argues that in today's society the dynamic between parents and children is fundamentally shifting. The parent and child relationship that was once enclosed by an authoritarian framework is increasingly becoming challenged by negotiation. Valentine asserts that children's spatial boundaries are beginning to be negotiated, as parents are becoming increasingly dependent on their child's localised knowledge. Included in these negotiations, is the child's social competence and their local knowledge that is no longer dependent on preconceived ideas of competence simply due to biological age. In this context, children are able to have an influence over their parents as they negotiate what they can do as well as where they can go (Williams \& Williams 2005). As Valentine puts it:

Rather, children actively challenge parental performance of authority. Often where parents' performances are weak and children's are strong, children can resist parental restrictions on their use of space and indeed often have a significant voice in household decisions. (Valentine 1999: 150)

This is linked in the work of Stephen Williams and Lynda Williams (2005) to the de-traditional processes at work in late modernity as the democratisation of all family relationships proceeds at a pace. Today's children are therefore influencing their spatial boundaries by developing a "new" negotiated relation- 
ship with their parents. Lynn Jamieson and Chris Toynbee (1990) had historically traced the decline of the authoritarian parent through the twentieth century. They believed that "it is probably true to say that many contemporary parents are closer to their children and treat them in a less authoritarian way than their own parents did. Indeed, there is a good deal of evidence supporting the claim that parents have become far more child-centred." (Jamieson \& Toynbee 1990: 108) Although in the last instance parents can still use their economic power and physical strength to demand their parental authority, this becomes increasingly difficult to justify in our late modern society.

It appears that it is no longer acceptable for traditional authoritarian roles, such as the patriarchal father, to demand the privileged position they once held in family relationships. In fact, it has become the "norm" for all participants in late modern relationships to demand their personal and emotional fulfilment within these new roles. It is also held, that marriage and kinship relationships can no longer survive based solely on traditional ascribed duties within familial roles. These "new" partnerships must provide individual love, emotional support and a sense of a united front against the world, as Beck and Beck-Gernsheim (1995) argue:

The sort of change evident in the marital relationship as society moved from pre-industrial to modern times is also apparent in the relationship between parents and child. In both, the common cause - the survival of the family unit - has disappeared; in both, the relationship between the persons involved is less economic and more personal and private, with all the hopes and interests this involves; in both, the relationship depends largely on the growing, not to say hypertrophic emotional needs of all parties in an individualised world (including all the rewards and horrors inherent in intense feelings). (Beck \& Beck-Gernsheim 1995: 105-106)

Thus, the emphasis on what some describe as the pure relationship (Giddens 1992; Jamieson 1999) has shifted, in these terms, from failed relationships of marriage and adult love towards the unconditional love between parent and child. The child is becoming the object of unconditional love, as individuals seek to develop a continual, constant and unfailing emotional love in their increasingly fragmented and unstable lives. The relationship with your children appears to be the only way parents can "guarantee" a source of love that will not fail, as their other relationships appear to be constantly failing. Anthony Giddens (1992) has pointed out that this relationship is no longer authoritarian as negotiation and compromise are all included in this new partnership. In fact, Beck \& Beck-Gernsheim (1995) argue that adults now express all their 
emotional fulfilment through their children, and thus invest their emotional as well as financial capital in their offspring. Children have become an investment and expensive commodity for the expression of unconditional love. To fully understand these social changes as well as detect the complex and sometimes contradictory nature of reflexive fathering, we must now take a brief look at reflexive modernity itself.

\section{REFLEXIVE MODERNITY? DECISIONS, NOT SIMPLY CHOICES}

Changes to traditional roles within the reflexive modern world mirror and are partly driven by, the speed of change in the communicative industries which helps to alter traditional social relationships (Castells 1999; Bauman 2000). Beck et al. (1994) and Beck-Gernsheim (1998) have each outlined these late modern processes and their complex social significance, particularly when looking at the recreation of new social roles such as reflexive fatherhood. Reflexive modernisation is quite simple in its basic concepts, although rather complicated in its resultant consequences. Reflexive modernity is the realisation that modernity has gone through two simple stages, a first "simple" phase of modernity and a second reflexive stage. Thus, within early modernity the public sphere aspired to be democratic and egalitarian, but the private sphere remained largely patriarchal, undemocratic and centred on the male's dominant economic position (the breadwinner). In real terms, this meant that women were in a subservient, ascribed position and were separated from the economic power that work provided. In the reflexive stage of modernity, however, the public and private spheres start to merge and the dominant economic position held by men begins to be eroded. As Anthony Giddens explains:

Modernity always set itself against tradition, but in many areas of life, tradition persisted particularly in everyday life. The reason was primarily the dominant position of patriarchal family, which remained un-democratized. That family form, together with the norms of gender and sexuality associated with it, is now breaking down creating both opportunities and dilemmas in its wake. (Giddens 1998: 118)

Subsequently, the family is becoming democratised by the de-traditional forces of reflexive modernisation. De-traditional ways of living are part of what Beck (1992) describes as the "individualisation" of all social and economic relations, and occur where the individual is forced to respond to the breaking up of the traditional order. Individualisation is therefore viewed as occurring in all areas of social life, as the individual becomes self-monitoring and reflexive. Thus, 
the main difference between postmodernity and reflexive modernity is that postmodernism rejects the idea of a narrative of progress, while reflexive modernity is a continuation of the modernisation process itself. In a way we have a dialectic process taking place, with the old thesis being challenged by a new antithesis and the resultant synthesis combining both the traditional and the new or non-traditional.

In this light new roles developed in reflexive modernisation could be seen as the unintended consequence of the dialectic of the enlightenment project, and thus as an outcome of a conflict between the traditional and the new in the modernisation process itself. Indeed, Zygmunt Bauman (2000) makes a similar argument when drawing an analogy between late modern forms of work and the increasing popularity of co-habitation as an alternative to marriage today. Bauman contends that:

The present-day "liquefied", "flowing", dispersed, scattered and deregulated version of modernity may not portend divorce and the final break of communication, but it does augur the advent of light, free-floating capitalism, marked by the disengagement and loosening of ties linking capital and labour. One may say that this fateful departure replicates the passage from marriage to "living together" with all its corollary attitudes and strategic consequences, including the assumption of the temporariness of co-habitation and the possibility that the association may be broken at any moment and for any reason, once the need or desire dries out. (Bauman 2000: 149)

In this excellent analogy, Bauman links the behaviour of global capitalism to the changing nature of relationships in postmodernity. In other words, in reflexive modernity it could be argued that the very transient nature of modern capitalism has a causal effect on the instability and changing character of late modern relationships. Consequently, globalisation has a profound impact on how we live, what we are and what we wish to be. Reflexive modernisation is therefore an explanatory tool in understanding the break-up of traditional roles, such as fathering, and their replacement by individualised fragmented "selfcreations", or what Giddens terms "self-monitoring". These "self-creations", however, are rather paradoxically not entirely due to personal "choices".

Essentially, reflexive modernisation holds that we as individuals have and must make decisions, but decisions peppered with a variety of personal experiences. Risk society has pushed modernity into reflexive modernity as the result of the unpredictability of all our actions. With regard to society, it is the side effects of the modernisation process that produce change. Change starts from the problems inherent in simple modernity, an example being environ- 
mental problems caused by industrialisation, and this is only revealed to individuals when modernisation produces unintended circumstances. Therefore, intrinsic motivations within the modernisation process have no certainties and progress is unforeseeable. Subsequently, we cannot predict where the flexible nature of global capitalism will direct us, and thus we cannot fully predict the outcome of these unconscious effects on institutions like the family. With regard to the family, we are witnessing changes that are the outcome of reflexive modernisation including the democratisation of family life, greater female participation in paid work and the increasing abandonment of traditional ways of life. One of the basic principles behind the concept of reflexive modernisation is the idea of a transition from traditional society to post-traditional society. Reflexive modernisation is the opposite of simple modernity, wherein positions or roles are entrenched in a rigid ordering. By contrast, today we can increasingly detect the promotion of the individual through self-monitoring and responses to situational necessity.

As with post-modernity, reflexivity is the central plank in reflexive modernisation, although the latter is marked by a different type of reflexivity. Thus, Beck (1994) emphasises reflexivity as having both an unintended element and a conscious element to change. This position has similarities to the earlier work of Giddens (1984) on structuration theory. Beck makes this point clear when he disagrees with Lash (1994) over the nature of reflexivity. His criticism of Lash is that he over-emphasises the postmodern notion of reflexivity, which stresses reflection or choice. It is this understanding of reflection and reflexivity that is central to this thesis, mainly because of a critique of the postmodern understanding of choice and cognitive "options". As Beck et al. argue:

Scott Lash distinguishes between cognitive, moral and aesthetic reflection. To that he connects the objections to Giddens and my own work, that we base our argumentation on a cognitively foreshortened understanding of reflection... This is accurate in one respect, simply because so far only Lash has worked out the indubitably important aesthetic dimension of reflexive modernisation. At the same time, however, this objection misses the central distinction between reflection (knowledge) and reflexivity (unintentional self-dissolution or self-endangerment) which is the basis of my argument. Putting it another way, it is precisely the distinction between cognitive, moral, and aesthetic dimensions of the reflexive modernisation which make it clear that Lash speaks exclusively of (more or less conscious) reflection, and misunderstands the problematic of unconscious, unintended reflexivity in the sense of selfapplication, self-dissolution and the self-endangerment of industrial modernisation. (Beck et al. 1994: 176) 
When applied to a social role such as fatherhood the dual composition inherent in reflexivity has two effects: conscious choice and decisions created by situational circumstances. So, when fathers become reflexive in their role as a male parent this is not entirely reliant on egalitarian personal attitudes or choices. The unconscious effects of modernity's self-endangerment and its unforeseen consequential side can also direct individuals to specific "limited options". The decisions made by fathers with regard to their role have an element of personal choice, but these are "choices" driven by household necessity. One of the major unintended consequences of modernity is a result of women going back to work, staying in employment or even deciding not to work at all. In this light, fathers have to respond to this situation, either positively or negatively, and the decisions they make have an effect on their own role as well as implications for their relationship.

Decisions in all areas of life reveal that social categories, even the ones which were once deemed biologically rigid such as gender and sexuality, are becoming contested in this de-traditionalised phase. As Beck explains:

The same thing can be observed and illustrated in the erosion of male and female roles. At first sight the argument sounds familiar: equality of women in the labour market is abolishing the familial foundation of industrial society. But that only means that the basis of the division of labour and its certitude is crumbling. Here the "classical" roles of men and women mix and subvert one another. That should not be equated with the displaced scenarios of wealth-risk conflict either. Instead it means loss of certainties, insecurity, deciding, negotiations and thus communication and reflection as well. (Beck 1992: 180)

Consequently, to determine the state of fatherhood today we must examine a vast array of decisions with which fathers are increasingly faced. These decisions are conflict driven as partners "fight" over who works, childcare arrangements, new negotiated relationships after divorce or separation and even who does what with regard to domestic responsibilities. Through all these arguments, new roles are driven by demands for justice, citizen's rights and a detraditional view on partnerships, marriage and work. All this is part of the individualisation process driven by risk society. Included within individualisation is the break-up of traditions, such as gender and tradition, as household lifestyles are becoming increasingly situational. Universalised provisions and categories are being replaced by an increase in situational decisions regarding the self, self-improvement and household circumstances.

The point that we must take from this theoretical discussion is that if these theorists are correct, we should be able to detect a shift towards a more affec- 
tionate father expressing the delight of being a parent. The biggest problem with this concept is that it is virtually impossible to quantify what exactly constitutes fatherhood. This problem is apparent in the earlier work on fathering by Charlie Lewis and Margaret O'Brien (1987). They argue that research on fatherhood has concentrated on fathers almost wholly within the workforce. In contrast, there has, historically, been a paucity of research on what fathers do in the home. This leaves us with a virtually impossible task of comparing today's fathers with earlier generations, because the literature lacks a historical base. Conversely, the fathers in this study always compared themselves with their own fathers, and appear to have both a set of traits attributed to the past fathering role as well as the new more reflexive role.

It seems that in earlier epochs, particularly in early modernity, traditional positions were not questioned and instead, were largely simply done. In late modernity fathers, mothers, children, grandparents and all kinship associations are developed on a one-to-one basis opened up by the reflexivity of institutions and structures. This idea is the basis behind the pure relationship and the reflexive as well as the self-monitoring principals of reflexive modernisation. The interviewed fathers are tacitly aware that they are doing something different and new, but they are also very concerned that they do not make a different set of mistakes.

These fathers have begun to change traditional fathering, as they are put under intense pressure from their changing family. They have all challenged traditional fatherhood in one way or another, either consciously or unconsciously, by their actions and deeds within family life. Virtually all the fathers interviewed expressed a delight in being a father and expressed a wish to be involved with their own children, something very different from the economic father presented by other research. They all considered themselves to be good fathers and wished to experience parenting in a more positive fashion than their own fathers. The exact meaning of male parenting involvement was individualised, and even discipline was up for negotiation within the father-child relationship. Simon, a deputy head-teacher, exemplifies this opinion when discussing discipline, arguing that he could not demand his children to be as obedient as he was. He asserts that one cannot place demands on today's children:

Simon: No, that's right you can't, you have got to negotiate. Again it starts when they are young and you have an open relationship. There are three types of fathers, parents, aren't there? You have got your authoritative and you've got your liberal. And I like to think I am between liberal and authoritative. 
Simon has two boys who are 15 and 17 years old, and explained that he wanted to be distinguished from an acquaintance. He recounted an experience of when an individual had told him that he needed to control his sons far better and he should not let them go alone into town. Simon believed that he could no longer dominate his children to do what he wanted. He argued that this was the case because they would not "take any notice" and negotiation was preferable, rather than not knowing where they were. For him, this exemplified a new "liberal" fathering approach.

Fathers were not only adapting to their children, but also reacting to what they felt to be "better" fathering. They drew upon mundane assumptions of good fathering, and compared that image with media panics about absent "bad" fathers. All these fathers talked about issues such as involvement and time with their children. This was fairly constant throughout the interviews, as the fathers spoke of increasing both their time spent and involvement with their children. Involvement ranged from the nurturing of children right through to the "usual" fathering activities of playing games. However, they did not see their individualised involvement on an equal basis with the partner, and sometimes appeared to be very traditional. Alan explained that his involvement was in one sense very traditional, as he was normally involved with their leisure time and homework. This type of involvement was expressed by a substantial number of the interviewees (over half), as Alan states:

Alan: It's probably with their leisure time like, when they are outside their school environment. But I spend a lot of time with them leisurewise, and obviously with their homework and things like that, normally after school.

Alan admits, however, like so many of the fathers, that his involvement and the time he spends with his family are limited by work commitments. Nevertheless, perhaps in contrast to previous fathering generations, he attempts to spend as much of his "spare" time with them. For an overwhelming majority of these fathers, "being involved" meant participating in all aspects of their children's lives and this was a recurrent theme. Individual interpretations of involvement also appeared to be reliant on other "factors". Categories and labels such as the good lone parent father and the bad absent father appear to be arbitrary, and dependent on individual circumstances. Mike, it could be argued is a good father, because he is presently a lone parent looking after his teenage daughter, and yet his involvement appeared dependent on the age of his daughter. However, when his daughter was a baby he could be described as an absent father. As Mike explains: 
Mike: Like I said, we split up two or three months after the birth. And then the mother looked after my daughter or her daughter for, I would say the first four years of her life, and I'd see her at first when she was little, I didn't use to see her that often. But when she got older and a little bit more independent then she didn't need her mother so much, I'd started having her on Sundays but then it moved to weekends.

Q: So why do you think that you never saw her that much in her first years?

Mike: I think first of all it would have to be something to do with me. Because, I mean, she is my daughter and it's up to me, it's not like my daughter can see me, I've got to make sure I see my daughter. But also I think you need that initial period when you've just broke up of separation so you can get your heads together and everything like, you know. So I would have to say it was my fault why I never saw her, but it is also the fact of you know I hadn't ever changed a nappy in my life and my daughter was getting breast fed ...

Mike's life history is complicated, however looking at his comments we can detect two separate issues. One was that the strong normative expectations of motherhood impinged on his sense of fathering, he felt that his daughter was too small and delicate for him to feed and nurture. The second issue must be how close both absent fathering and "new" fathering can be; this could negate the right wing talk of immorality amongst "absent" fathers and a separate underclass "culture".

There were also other types of involvement that appeared to depend on the age and gender of the children. When Graham discussed his involvement, age and perceived gender differences between sons and daughters were other considerations. This appeared to be suggesting that time was more important for his young daughter, whilst support and a chat was good enough for his older son. As Graham explains:

Graham: Yeah I always try to make time for them. I suppose that [daughter] at the moment is the one I spend most time with, generally she goes to bed early. When you go and try to have a chat with [son], it's like, oh dad I am one nil up, come on, get out (laughter). He is 13, he doesn't really want to know me.

Graham stated that his 13-year-old son "doesn't really want to know me", yet they connect in another more "traditional" masculine activity: football. Graham, like a lot of the fathers interviewed, wished to behave differently towards his children when compared with his own father's involvement with him. Early in the interview Graham argued that his father never took an interest in his 
football, and he has made sure that he has taken an interest and connection with his son's football. On the other hand time was of more importance for his daughter. This is an interesting mixture of modified traditional fathering with the son and a "new" type of created involvement with his daughter. As Graham explains:

Graham: Umm, well now, it's when I mostly get home from work. You know... umm... I just always made time for... who's the daughter, who is 4 ... umm... [son] is generally upstairs playing his computer or whatever they call it... umm ... But I can get along with him greatly. We have the same interests, the same music interests, which I never ever impressed upon him. He just happens to like the same... umm... The football he likes the same sides as me.

Involvement was a constant theme, although the precise meaning of involvement could sometimes be quite varied and ambiguous. What "involvement" meant for one father was different for another, individualising the exact meaning. Ivor, a father of one, saw reading and contributing in the nurturing side as involvement:

Ivor: Oh yeah I am involved with her as much as I can be really, and... umm... I do get involved in everything she does. Well I will try to help if she is reading, I help her read, I read her to sleep. I put her to sleep most of the time.

Warin et al. (1999) found that fathers get involved in ways other than the classical nurturing involvement related to the motherhood role, and have instead become engaged in areas, not looked at by a number of researchers, e.g., being the family "taxi-driver" with teenagers and "playmates" on the playstation. Unlike in the study by Warin et al. (1999), the fathers, interviewed in the course of the current research, did more, and wanted to do more, than just play with their offspring. Playing was not the only way these fathers involved themselves with their children. This group involved themselves in more traditional nurturing activities, although even here involvement was not exactly equitable. Dividing involvement on gender grounds seems to be quite common, and as we have already seen above, involvement also changes with the age of the children, as Dave explains:

Dave: With [his son], cos he is nine years old, I am more involved with him, when it comes to things like school work, playtime, playing, going out, things like that. With the twins, with the girls, they are twelve years old now and the girls umm... again I do some homework with them, but not much strangely enough. And going out they are becoming 
more independent and they rely upon us less for their entertainment and their social time.

Individual differences in the way these fathers become involved with their children are very distinct, and as with other areas in fathering individuals select their own type of involvement. Ivor, the motor mechanic father of one daughter exemplified this point very well when he explained his individual fathering style:

Ivor: Well, you know, we try and share things, we go out together, you know food, you know she's having a meal with us, cutting her food type sort of thing, talk to her, make sure she is content. If you're waiting for food in a restaurant or whatever, play with her when she is out.

Ivor showed a mixture of traditional and de-traditional fathering, playing and helping to feed her. The late modern father's relationship with his children is much more complicated than in previous generations. Although breadwinning is still central to the majority of these fathers' sense of self, they are developing or beginning to dabble in other areas of parenting. Prescribed traditional roles are being replaced by a greater amount of "voluntaristic" types of fathering created by greater choice or decisions.

In other words, changes in the labour market and the demands for citizen's rights by women are beginning to slowly change the position of, and demands on fathers. In the words of Beck \& Beck-Gernsheim (1995), fatherhood has become a consequence of individualisation, where expectations are not fixed in stony tradition and are developed by individual life styles. The point here is that fathers are no longer "just" breadwinners or "just" role-models but are pushed by circumstances to be something more than a singular one-sided icon. Feminists in the past have said that mothers had to be great chiefs, brilliant maids, Florence Nightingale nurses and wonderful lovers; well, to a certain extent its payback time as the same is now expected of the male. However, perhaps unfortunately, "wonder-man" has still not arrived and only a mere, at best, "blundering male" exists.

\section{BEING AT THE BIRTH}

The change in the lives of these men when becoming a father is considerable, and this clearly illustrates that fathers do more than just provide finance. Theodore Cohen (1993) reveals the impact of this change in a study that examines men before and after fatherhood. Fatherhood in Cohen's study was clearly not only an economic function, but also has an emotional element. This emo- 
tional involvement and willingness to be part of their children's lives was mostly exemplified by being at the birth. Virtually all the fathers expressed their opinion that the father should attend the birth, with very little reservation (only two had reservations about fathers being at the birth). Consequently, being at the birth seemed to serve a few general purposes in the experiences of these fathers. The first was an emotional release and a feeling of euphoria at the birth of their child after the long pregnancy. The others include a type of solidarity with their partners, sharing the emotional phenomenon, attempting to understand the pain involved in childbirth and bonding with the infant. The excitement and emotional fulfilment of being at the birth had traditionally been denied to men, but these fathers wanted more than just sitting outside in the waiting room.

Sometimes, however, even this can still be denied to a father, as traditional ideas prevail with individuals in the medical profession. As Richard, the taxi driver, explains: "I was there to do the fatherly bit and holding the wife's hand and this big hefty sister came out, pushed me out of the way and said if you're going to faint you'd better do it in the corner." These fathers gave the overwhelming impression that they very much enjoyed being at the birth for varying reasons. To Duke, the deputy head of a secondary school, this was his way of involving himself as much as he possible could with the birth and the arrival of a planned as well as much wanted first child.

Duke: Personally yes I wouldn't have missed it for the world, because umm... we wanted this baby a lot, it was our first baby anyway and we wanted it. We had been married three years by then, and we settled in, done the things that you do when you're first married, and we wanted this baby to come and I wanted to be there and be part of it. I enjoyed my wife's pregnancy if you see what I mean and when we look at the photos now of when we umm... you know taken just a few minutes after the baby was born, I don't know who looks more exhausted me or her.

This appeared to be a time when the acceptable emotionless hegemonic masculinity could be relaxed. Fathers were allowed to become sensitive and experience the 101 joys and emotions of becoming a parent. Steve replied in this fashion when asked how he felt during the birth of his children:

Steve: I was there and observed, watched and went through 101 different emotions. Other than that, and support and encouragement I don't really know how else I could have been involved.

Adjectives such as "emotional", "elation", "fantastic" were frequently used to express their feelings at becoming fathers and this type of experience was 
spread right across the survey. Peter and Graham are the best examples, and eloquently express the feelings that new fathers feel towards their children. Peter also believes that this emotional expression could not have been shown 20 years ago. We can view this change as illustrative of how the breaking up of the traditional dominant masculinity is allowing greater individual expression of the men's emotional selves (Connell 1995; Giddens 1992; Williams 1998). Childbirth for Graham, the industrial roofer, and Peter, the bank clerk, was a real emotional experience even though, in both cases, becoming a parent was not planned. The emotionally charged atmosphere of childbirth helped them bond with their children and also help them express their feelings, as they explain:

Graham: Just the sheer elation isn't it, it's fantastic, it's almost unreal. Well it is unreal, because you've never had to cope with those feelings before. You've got something there that's just, oh it's just fantastic. There is something there that's real, it's looking at you and it's just, you know, you have to do as much as you can for it for the rest of your life. You know that there and then, it's that inner warmth, it's that bond straight away.

Peter: I found it very emotional when [daughter] was born. I did shed a tear but uh... I think it's all down to the individual, if they're going to be emotional... about 20 years ago men were men and didn't show any emotions. I think the last 20 years there's no pressure to be one thing or the other.

An interesting opinion held by fathers was a mistrust of the medical profession. These fathers wanted to be at the birth to protect both their partners and their unborn child. This opinion suggests that there is a problem with trust in late or reflexive modernity. This same point has been argued by Beck, Giddens and Lash (1994), and Bauman (2001), that as risk creates individuals who no longer accept the absolute authority of such modernist institutions. Ant's trust in an institution, such as a hospital, was severely tested by the birth of his child. He was uncomfortable, reluctant and unwilling to concede their autonomy to the medical staff during childbirth. Ant explains that he worried about his partner, their unborn child and the competence of the medical staff:

Ant: The medics turn around and say, and were basically saying, look you know what you were more worried about the well-being of your wife, or of the unborn child. And it's very difficult thing to be in, it's actually, kind of, having to weigh it up. I mean because they were... It was sort of a few minutes from caesarean, and they were doing all sorts of absolutely horrible tests on [his wife]; like doing a blood sample test 
before it was born and stuff. Which... it was difficult, because I wanted the baby to be as well treated and looked after as possible, but they were also doing stuff that was kind of hurting my wife a lot, so it was difficult.

Simon, the deputy headmaster, and Leon, the steelworker, also expressed this theme, as trust in the medical profession appeared to be increasingly put in doubt. This opinion appears to be driven by concern for their partners and their unborn children, yet also by the increasing available knowledge and understanding of the risks involved.

Simon: To support the wife, but also if anything goes wrong to put pressure on, possibly, you know the professionals. Because you know there can be a tendency to sort of let women go too far, and when it's gone too far then, you know, that's when the problems start, isn't it.

Leon: Yeah, for the supporting role and to make sure the doctors and nurses are doing their jobs properly. I spent months and months and months in hospital; the two of them were premature (pointing at photographs). She weighed $2 \mathrm{lb}$ when she was born, and she was $1 \mathrm{lb} 12 \mathrm{oz}$, I think, less than a bag of sugar the pair of them. So I could see how badly or how well the doctors or nurses are in there. So just keep an eye on things like.

Increasingly, fathers and parents in general are beginning to doubt the professionalism of expert systems. This appears to be exacerbated by the media coverage of medical mistakes and experience with dealing with such institutions. The overall feeling for these fathers was that they needed to deal with these problems on an individual basis, as collective institutions could no longer deal with individualised need. Another individualised problem was dealing with a long-term illness of a partner. This "forced" these fathers to take on greater involvement with the everyday duties of parenting. Individualised parenting appears to be driven by situational necessity and once these fathers took on more responsibility they appeared to continue even after their partners recovered.

\section{PARTNER AND CHILDHOOD ILLNESS AS A FACILITATOR IN FATHERING INVOLVEMENT}

One of the driving forces behind a father's greater involvement with their offspring is a situational one. Increasingly, parents are rearing children away from kinship support, or that support is not there for one reason or another. 
Consequently, if any problems occur with one or other of the partners, they have to either arrange expensive outside childcare or increase the involvement of the healthy partner. This is precisely the problem faced by a number of the fathers I interviewed. Over a quarter of the sample said that they increased their involvement within the family unit as a result of illness to their partner or child. Given that traditional kinship groups are breaking down, reforming, or being renegotiated it should not be a surprise that households are left to "sort out" their own problems.

This idea is not entirely new as Michael D. Young and Peter Willmott (1973) explained in their work The Symmetrical Family, although in their study, this was caused by the creation of the nuclear family stretching kinship ties. Today, however, it is not the creation of the nuclear family, which is at the centre of this change; rather it is the de-traditionalisation of the entire social structure. De-traditionalisation driven by individualisation leaves the individual alone, or with minimal negotiated help, responding to the unforeseen circumstance of late modern life. Negotiated help may take the form of kinship help, if family will/can help, or paid outside childcare. Nonetheless, a quarter of the fathers in this study responded by involving themselves as much as possible without totally relying on others. Their particular type of fathering has led to increased bonding with their children, and to a greater awareness that fathers were also parents. Phil became a father later in life, and before the birth of his daughter his wife had several miscarriages. This had the quite understandable result of Phil taking a large interest in his partner's wellbeing and that of the unborn child. After outlining the involvement in his partner's pregnancy, and how he juggled work with going to all the hospital appointments, Phil went on to describe his feelings towards his partner, child and what he thought should be modern fatherhood:

Phil: I think the role of the father has been overlooked. Everybody looks towards the mother and says yes, it's the mother who looks after the child and the mother does this, and the mother does that, and the father is getting left out on the ledge. But what I've found is that we have a traditional marriage but in a modern time, and a lot of the work is actually done by me. Or at least it's not a lot of work, we share, we share the work with the baby. I feed the baby now the baby is going onto mix feeding. I feed the baby, I change the nappies, I bath the baby, I put the baby to sleep... So there's no longer a demarcation line, it's not just the mother who looks after the baby. I think it's a duo, a partnership, and the father's part of that partnership is a very important role within the marriage and the family. 
Lewis, a student father, is another example of increased fathering involvement in the nurturing of children, due to partner's illness. Many of the fathers interviewed became involved in this way and Lewis best demonstrates this type of involvement. Lewis explains how he and his wife attempted to deal with her post-natal depression, and how they shared the nurturing of their baby.

Lewis: Well [his wife] was seriously ill, with post-natal depression for two years after baby was born. She needed her sleep and so she insisted on breast-feeding for a length. I think she breast-fed for over a year in fact, um but I would feed in the middle of the night from milk she'd saved up, and what have you, because basically I can survive on less sleep than she could.

Being "forced" into a greater nurturing role appears to help the father come to terms with being a parent. As we can detect from the comments above this turns out to be an emotionally fulfilling experience for the fathers involved, and appears to create a better bond between father and child. This should be food for thought as policy makers grapple with issues such as paternity leave. Swedish social policy enables the father to take paternity leave as part of a combined parental leave, helping fathers to bond with their young babies (Haas 1993). Making a father take the step into the domestic sphere appears to make them more aware of their parental responsibilities. On a similar line, and a constant theme amongst these fathers was the moment they realised they had a dependent. Dave exemplifies this when faced with his wife's unconscious state after the birth of their twins; it was then that he first became fully aware of the enormity of being a father.

Dave: I think I first became a father in the truest sense, when [his wife] was, after the caesarean [his wife] was anaesthetised. She had the full, she went under fully, and I was left with the babies, the twins, while [his wife] was completely asleep for hours and hours... So it was thrust upon me, and I thought immediately, these children have no one except me. At that moment with [his wife] being out of it, there was no way that I could just leave them. I could have left them with a nurse in theory, but that's not what I felt. I felt that I had to be there to protect if you like.

These fathers are attempting to build new relationships, which are free from any ascribed norms inherent in older more traditional relationships. Therefore, they do not want to be excluded from any experience, especially anything that helps them bond with the child. Becoming a friend to their children and being involved with all aspects of their children's lives was expressed by the 
majority of these fathers. Being close to and listening to one's child was taken even further by Clive, when he declared that he has a better relationship with his daughter than his wife does. He believed that his wife did not have as much patience, and his daughter comes to him for advice in all areas, even on a topic such as sex.

Clive: I am very, very close to my daughter. More close to my daughter than what my wife is. My daughter comes to me for, you know, we talk about sex, everything, you know openly, and she comes to me not her mother, because I am the type who has got common sense. I sit and listen...

The fathers confirmed that they wanted to be involved in the lives of their children. They demonstrated a better understanding of their children's needs and their own emotional expression was far better than that of their fathers. Overwhelmingly, these fathers wished to be involved with their children and showed a variety of activities in which they became involved. As with other areas in fatherhood, inclusion in the family process was dependent on decisions made by family circumstance. As fathers, these male parents benefited from creating new relationships, either by unintended circumstance or conscious choice. They had to respond to a situational need in their relationship and this appears to have given them a positive outcome in parenting skills. Rather than in some other researchers' role inadequacy model of fatherhood where fathers are incapable of nurturing and incompetent, these fathers did an adequate job and this was then incorporated into their own fathering practices.

\section{CONCLUSION}

This paper suggests that fathering is becoming very disparate and diverse. These fathers portray variations in fathering styles from the traditional to detraditional fatherhood. It also enlightens us as to how fathers negotiate spatial boundaries with their children, and appear to be building something different in their father/child relationship. It seems that although the power relationship between child and adult still obviously exists, a better relationship is increasingly about understanding each other, not the authoritarian patriarch of previous generations. Boundaries still have to be set but these boundaries are discussed and negotiated rather than dictated and demanded.

Fathering, and mothering, is no longer an entirely traditional, powerful, demanding and dominating force, good parenting has to be thought out indi- 
vidually and decisions made for the benefit of the unit as a whole. Fathers still appear to be pressurised by some social policies to be traditionally strong and a good role model, yet they are also pressurised by their own individualised relationship to be more loving and understanding towards their children. Fatherhood is becoming more and more fragmented as idealised models, seen in "simple" modernisation, are increasingly becoming obsolete or just another option in many. Individualisation is the diversifying force that creates the late modern father, tradition slowly disappears as individualised fathering takes its place.

One of the greatest perceived changes amongst this fathering group was towards being at the birth. These men, virtually all, believed that it was important for the male to express his love and emotions towards his partner and about to be born child, by "sharing" the experience of childbirth. Many of these men said that they cried at the birth and felt more emotionally attached to their children by the experience. Two of the fathers had their children over an extended period, about twenty years apart, and they felt that they missed out on this emotionally fulfilling experience with their first child. They felt that the change in policy, by health authorities, to encourage males into the delivery room was a bonus for new fathers. Sharing the experience appeared to be very popular amongst fathers, and probably for the first time triggering the understanding that they were actually fathers, long term.

Despite some of the traditional views still maintained by some fathers, such as being just a playmate and that their partners were overwhelmingly responsible for the nurturing of their children, fathers did respond well to a family crisis. It was clear that when a partner became ill the father did not look for total support from kinship groups; instead, they took over the nurturing duties and did them quite well. Concern for their partner as well as situational necessity triggered off this response. Interestingly, after their partner's recovery they still continued to be involved. Involvement, however, depended on the subjective interpretation of each individual father. Involvement was an individualised construct that ranged from playing with the children to being fully involved in all aspects of childcare. Fatherhood was therefore subject to individual preferences, structural change and the family's particular situational need.

It seems that when there was a situational change in their family circumstances, gender roles were abandoned, as it was a case of "all hands to the pumps". Therefore structural influences are very strong but not irreversible, and the agent can alter his own role as well as interact with the structure as a whole. It was evident that the dominant hegemonic masculinity is still an influence, but its influence is certainly beginning to be eroded by the eclectic 
mixture of new options available to men. Relationships between father and children are both at the same time traditional and new. Fathers in this study wanted to be involved and some were in the process of creating a new relationship between father and child, yet to encourage this further, more government policies should be created for fathering inclusion. Reflexive fathering is improving this traditional role, yet traditional fathers still exist but are increasingly in the minority and slowly disappearing.

\section{REFERENCES}

Bauman, Zygmunt 2000. Liquid Modernity. Cambridge: Polity Press.

Bauman, Zygmunt 2001. The Individualized Society. Cambridge: Polity Press.

Beck, Ulrich 1994. The Reinvention of Politics: Towards a Theory of Reflexive Modernization. In: U. Beck \& A. Giddens \& S. Lash. Reflexive Modernization: Politics, Tradition and Aesthetics in the Modern Social Order. Cambridge: Polity Press.

Beck, Ulrich 1992. Risk Society: Towards a New Modernity. London: Sage Publications.

Beck, Ulrich \& Beck-Gernsheim, Elisabeth 1995. The Normal Chaos of Love. Cambridge: Polity Press.

Beck, Ulrich \& Beck-Gernsheim, Elisabeth 2002. Individualization: Institutionalized Individualism and its Social and Political Consequences. London: Sage Publications.

Beck-Gernsheim, Elisabeth 1998. On the Way to a Post-Familial Family: From a Community of Need to Elective Affinities. Theory, Culture \& Society, Vol. 15, No. 33, pp. $53-70$.

Beck, Ulrich \& Giddens, Anthony \& Lash, Scott 1994. Reflexive Modernization: Politics, Tradition and Aesthetics in the Modern Social Order. Cambridge: Polity Press.

Beynon, John 2002. Masculinities and Culture. Buckingham: Open University Press.

Bittman, Michael \& England, Paula \& Folbre, Nancy \& Sayer, Liana \& Matheson, George 2003. When Does Gender Trump Money? Bargaining and Time in Household Work. The American Journal of Sociology, Vol. 109, No. 1, pp. 186-214.

Castells, Manuel 1999. The Information Age: Economy, Society and Culture. Oxford: Wiley-Blackwell.

Cohen, Theodore F. 1993. What do Fathers Provide? Reconsidering the Economic and Nurturant Dimensions of Men as Parents. In: J. C. Hood (ed.) Men, Work, and Family. London: Sage Publications.

Connell, R. W. 1995. Masculinities. Cambridge: Polity Press.

Dermott, Esther 2003. The 'Intimate Father': Defining Paternal Involvement. Sociological Research Online, Vol. 8, No. 4. http://www.socresonline.org.uk/8/4/ dermott.html, last accessed on 1 July 2011.

Dermott, Esther 2008. Intimate Fatherhood: A Sociological Analysis. London: Routledge. Dienhart, Anna 1998. Reshaping Fatherhood: The Social Construction of Shared Parenting. London: Sage Publications. 
Doherty, William J. 1997. The Best of Times and the Worst of Times: Fathering as a Contested Arena of Academic Discourse. In: A. J. Hawkins \& D. C. Dollahite (eds.) Generative Fathering: Beyond Deficit Perspectives. London: Sage Publications.

Giddens, Anthony 1984. The Constitution of Society: Outline of the Theory of Structuration. Cambridge: Polity Press.

Giddens, Anthony 1990. The Consequences of Modernity. Cambridge: Polity Press.

Giddens, Anthony 1992. The Transformation of Intimacy: Sexuality, Love \& Eroticism in Modern Societies. Cambridge: Polity Press.

Giddens, Anthony 1998. The Third Way: The Renewal of Social Democracy. Cambridge: Polity Press.

Haas, Linda 1993. Nurturing Fathers and Working Mothers: Changing Gender Roles in Sweden. In: J. C. Hood (ed.) Men, Work, and Family. London: Sage Publications.

Hawkins, Alan J. \& Dollahite, David C. (eds.) 1997. Generative Fathering: Beyond Deficit Perspectives. London: Sage Publications.

Jamieson, Lynn 1999. Intimacy Transformed? A Critical Look at the 'Pure Relationship'. Sociology, Vol. 33, No. 3, pp 477-494.

Jamieson, Lynn \& Toynbee, Claire 1990. Shifting Patterns of Parental Control. In: H. Corr \& L. Jamieson (eds.) Politics of Everyday Life: Continuity and Change in Work and the Family. London: Macmillan Press Ltd.

Lash, Scott 1994. Reflexivity and its Doubles: Structure, Aesthetics, Community. In: U. Beck \& A. Giddens \& S. Lash. Reflexive Modernization: Politics, Tradition and Aesthetics in the Modern Social Order. Cambridge: Polity Press.

Lewis, Charlie \& O’Brien, Margaret 1987. Reassessing Fatherhood: New Observations on Fathers and the Modern Family. London: Sage Publications.

Lupton, Deborah \& Barclay, Lesley 1997. Constructing Fatherhood: Discourses and Experiences. London: Sage Publications.

Morgan, David H. J. 1996. Family Connections: An Introduction to Family Studies. Cambridge: Polity Press.

Morgan, David H. J. 1999. Gendering the Household: Some Theoretical Considerations. In: L. McKie \& S. Bowlby \& S. Gregory (eds.) Gender, Power and the Household. London: MacMillan Press.

Silva, Elizabeth Bortolaia \& Smart, Carol 1999. The New Family? London: Sage Publications.

Valentine, Gill 1999. 'Oh Please, Mum. Oh Please, Dad': Negotiating Children's Spatial Boundaries. In: L. McKie \& S. Bowlby \& S. Gregory (eds.) Gender, Power and the Household. London: MacMillan Press.

Warin, Jo \& Solomon, Yvette \& Lewis, Charlie \& Langford, Wendy 1999. Fathers, Work and Family Life. London: Family Policy Studies Centre for Joseph Rowntree Foundation.

Williams, Fiona 1998. Troubled masculinities in social policy discourses: fatherhood. In: J. Popay \& J. Hearn \& J. Edwards (eds.) Men, Gender Divisions and Welfare. London: Routledge.

Williams, Stephen 2002. Reflexive Fathering: The Individualisation of Fathering. Unpublished PHD thesis. Cardiff: University of Glamorgan. 
Williams, Stephen 2008. What is Fatherhood? Searching for the Reflexive Father. Sociology, Vol. 42, No. 3, pp. 487-502.

Williams, Stephen \& Williams, Lynda 2005. Space invaders: the negotiation of teenage boundaries through the mobile phone. The Sociological Review, Vol. 53, No. 2, pp. 314-331.

Young, Michael Dunlop \& Willmott, Peter 1973. The Symmetrical Family: A Study of Work and Leisure in the London region. London: Routledge \& Kegan Paul. 


\title{
CONNECTING THREADS
}

\author{
Mirjam Mencej
}

\begin{abstract}
The paper is about symbolic meanings of spinning, the material (fibres - un-spun wool) for spinning and the results of this activity (thread, yarn). On the basis of comparison of the records of beliefs from different sources - ancient poetry and treatises, European folklore and ethnological data, and iconographic material - the author argues that in European traditional folk conceptions, spinning and the material and products associated with it refer to basic aspects of human existence, birth, fate and death. While un-spun wool is related to the otherworld, spinning and thread refer to the world of the living, link this world and the otherworld, and allow the transition between the world of the living and that of the dead.
\end{abstract}

Key words: birth, death, fate, otherworld, spinning, supernatural beings, thread

The paper is about symbolic meanings of spinning, an activity which formed an essential part of women's work at least from the early Neolithic period onwards, when the technique of continuous-draft spinning spread, probably in association with wool ${ }^{1}$ (Barber 1991: 50). Regarding the importance of this work for human beings it is no wonder that the activity itself, as well as the implements for spinning ${ }^{2}$ (such as distaff, spindle, spindle whorl, and spinning wheel), and also the material for spinning (i.e. un-spun wool, flax, hemp etc.), as well as the result of the process (thread, yarn) acquired many symbolic connotations, which are associated with the very basic foundations of human existence such as birth, death, and fate.

However, in order to understand the symbolism of the activity, which was known almost worldwide, I do not believe that it suffices to stay within the framework of the data given in any particular micro-ethnographic context. Europeans (and in many regards also peoples from a wider geographic region than Europe) shared many aspects of their worldview as has been convincingly argued in abundant research so far (see, e. g., Pócs 1999: 25; 2008: 89, 100; Vaz da Silva 2002: 2-10; 2003: 335; 2008: 2) and only by comparing ethnographic and folklore particularities from different places can we disclose a common core of beliefs related to spinning. Since records of belief, related to spinning and thread, stem from a vast period of time and very different places and genres, I found it necessary to compare all the sources - from ancient trea- 
tises, poetry, folklore and ethnological data, to iconographic material. Naturally, there are variations and specific details which differ, but essentially the same or similar ideas keep cropping up, in spite of geographic and temporal gaps between the sources.

\section{SPINNING AND SUPERNATURAL BEINGS}

One thing that is immediately striking, when taking into account European folklore, is the frequency with which spinning and spinning implements, yarn, thread, balls of wool, are associated with supernatural beings. Usually they are associated with female mythical beings and only exceptionally with male ones, a fact which is certainly understandable, as spinning was generally considered women's work (cf. Barber 1991: 4). Let me first make a brief overview of these beliefs, whereby I will deliberately choose those from widely distant times and areas so as to demonstrate that widely distant beliefs, attached to quite different supernatural beings, are in fact very similar.

In a Serbian folk poem ${ }^{3}$, recorded by Vuk S. Karađić, a well known 19th century Serbian folklorist, a female fairy is invited to spin:

Oh, cherry tree, little cherry tree,

Raise your branches,

Beneath you fairies

Dance a wonderful round dance,

At their head is Radiša,

With a whip she shakes the dew,

She leads two fairies,

And to the third she says:

"Come with me, fairy!

At my mother's place

You will sit in the cold,

\section{And spin the thin thread}

On the golden spindle. (Karađić 1972: 189, no. 25)

A spindle is a frequent attribute of various eastern Slavic supernatural beings, such as pjatnitsa, kikimora, mara, even domovoi who is male (cf. Valencova 2001: 103). According to folk beliefs from 19th century northern Russia (Olonetsk and Vologodsk provinces), mara (kikimora, shishimora) sits on the stove and spins yarn at night when everyone goes to sleep, but may also weave, knit, crochet and sew. Sometimes she pounds hemp or yarn and people may see her with a spindle or spinning wheel or assuming the shape of a wheel. A mocking verse referring to lazy girls also mentions kikimora in relation to 
spinning: Sleep, girl: kikimora will spin and your mother will weave for you. (Afanas'ev 1994 (1869)/2: 101-102; Maksimov 1989 (1903): 41-42; Krinichnaia 1995: 5-6)

Rusalka is similar to mara and kikimora in this respect: according to folk beliefs in the Kiev environs (Ukraine) rusalka works with thread, yarn, and un-spun wool, and she likes to spin or knot the yarn. Similar is the Ukrainian nichka, a supernatural female being who, especially on Friday nights, spins where women leave their sheaves of hemp. Ukrainians also know a local variant called komokha, who likewise spins (Afanas'ev 1994 (1869)/3: 139; Krinichnaia 1995: 6-7).

Baba Yaga who otherwise appears only in fairytales and is not a subject of folk belief, is also associated with spinning. Her hut is continually turning around on its axis like a spindle and rests on a bird's (usually a chicken's) foot which sometimes has a spindle for a heel (Kilbourne Matossian 1924: 332). In a fairytale published by Nikolai Onchukov in $1908^{4}$, we read: A hut stands on a chicken's leg, on a spindle heel, it spins in circles and you can't see the door [...] in the hut sits a woman, spinning silk, spinning long threads, the spindle spins and the threads fall beneath the floor. This is a depiction of Baba Yaga spinning with a spindle. The result of her spinning is a golden or silver ball of thread, which she also has the ability to turn herself into. In some fairytales she appears in a form of a spindle, or her hut is shaped like a spindle (Krinichnaia 1995: 9-11). In addition, Baba Yaga carries the implements used for the fabrication of cloth which relate to divination through the "spinning of fate" practised by her and her sisters (Farrell 1993: 735).

According to traditional German beliefs, an invisible little goblin (lutin $\left.{ }^{5}\right)$ was supposed to put a spinning wheel in motion if people did not twist the drive band of $i t^{6}$. In Scotland people used to pull the drive bands off the spinning wheels at night to prevent supernatural beings from spinning on the wheels (Sébillot 1981: 143).

In France (Saintonge), a belief was recorded at the beginning of the 19th century, among the peasant population, that fades and good spinners (bonnes filandières) walk around at night with a spindle in their hands and foretell the future (Devlin 1987: 84). Other supernatural beings, such as fées or lutins, came looking for yarn at night or worked on spinning wheels (Sébillot 1981: 142). In a French legend a fairy hides inside the yarn and is "locked" inside it as if she were in prison - if someone caught her and wrapped her up into a ball, the fairy would escape from the ball and free herself (Borghini 1999). In the province of Berry, George Sand (born 1804) recalled from her childhood speaking of a female spirit - a dwarf or a bad fairy - who liked to mix and knot the yarn (Devlin 1987: 87). 
In Italian legends, balls of yarn are associated with witches (who can appear in the form of balls of yarn, or can use balls of yarn as a sort of evil means for casting spells), but also with other supernatural beings that have negative and demonic abilities (Borghini 1999). According to Portuguese legends, recorded from the 19th century onwards, enchanted maidens called moura encantada endlessly weave and participate in spinning evenings (Cardigos 2008: 113).

In the Finnish tradition, the pleiades were pretty young women who were highly skilled at spinning and weaving (Catháin Ó 1995: 123). In Lithuanian legends recorded in the 20th century, weaving is performed by witches and female supernatural beings called laumé(Vèlius 2002: 21-22).

In addition to supernatural beings, who themselves spin or are in one way or another associated with spinning, spinning implements or products, we find throughout Europe many beliefs about the supernatural beings (Pechtra, Holda, Holle and others), who in certain periods of the year, according to folk beliefs, watch over spinning, punish lazy spinners, make sure that no spinning is done on days when spinning is forbidden etc. Many legends tell of the visits of these beings, and how they punish spinners who violate spinning taboos or fail to finish their spinning on time etc. They are frequently described in the act of spinning or as being equipped with flax, spinning tools etc. ${ }^{7}$ (Rumpf 1976; Kuret 1997, 1989/II: 458; Timm \& Beckmann 2003; for an overview see Mencej 2010).

When all across Europe we find such a wealth of legends and records of folk beliefs about supernatural beings related to spinning, then there must obviously be a significant relation between them. Surely it cannot be a mere coincidence that the link between supernatural beings and spinning is repeated across such a vast geographic area. The question, however, remains what the meaning of this relation is and why we come across it so often. Spinning certainly played an important economic role in traditional communities, but the answer undoubtedly lies in its symbolic rather than its economic function. In the following section I will argue that spinning is a typical activity of supernatural beings, which by definition dwell "in between" - precisely due to their liminal position between the two worlds.

\section{SPINNING AND THREAD CONNECTING THE TWO WORLDS}

The Portuguese legends about the moura, the enchanted women who spin and weave their "endless thread - the signal that their job is endless" (Cardigos 2008: 113) - make their liminal status very clear:

... A woman found a golden thread on her way to church. She pulled it and realised that the thread never came to an end, so she said to herself 
"this is enough for me to be rich", and she cut it off, for she did not want to miss the holy mass. As soon as the thread was cut it melted into blood and the woman heard shrieking and cursing. Had she delayed her pulling of the thread until mass was finished, the moura's enchantment would have finished. (Cardigos 2008: 113)

In her discussion of this legend Isabel Cardigos places particular emphasis on the connection between the moura's state of enchantment, which is already in itself a liminal position, and her endless thread: "We can see the clear homology between the moura's endless thread and her endless unholy state of enchantment ..." (2008: 113). The thread that never came to an end thus obviously indicates moura's liminal, "in-between", status.

In fact, we often find a (ball of) thread that never comes to an end in the hands of supernatural beings (fairies) in Slavic folklore, even if the fairy herself is not always the one doing the spinning. The balls of thread or cloth seem to stem from the otherworld as they never end and keep coming up as long as the winding up is not broken by cutting the thread or trespassing on a taboo. The thread thus creates a link between this and the otherworld.

In Russian folklore forest women give people balls of thread, which never run out unless being purposefully unravelled completely (Krinichnaia 1995: 7).

Slovenian legends tell about a fairy (vila, žalik žena), occasionally about a fate $(\text { rojenice })^{8}$ giving those who were kind toward them a ball of thread or yarn that never runs out, as long as they never say that it has "come to the end" or that they have "found the end". The following legend was recorded in Slovenia in 1857:

One of the fates, who lived at the top of the Mladi vrh mountain, was walking with a silver jug to milk Groselj's cows, which were pastured thereabouts. None of the herdsmen dared to say anything, because who knows! So, since none of the herdsmen said anything bad to her, she once brought Groselj some yarn and said: "This is in payment for your hospitality: wind it and it will never run out, only you may never say: "It has come to the end" or "I found the end". You had better say: "The thread has run out" or "I found the thread". If you don't say it like that the yarn will run out immediately." They did what the fate told them to and they became rich. They wound and they wound, but there was always as much yarn as they had started with. The herdsman who drove the cattle home in the evening had to wind the yarn until late at night ${ }^{10}$. Since herdsmen are usually lazy, one evening this one got sick of it and complained: "If only once, by the devil, just once this yarn would end!" And in fact that very evening the yarn ran out. (Kelemina 1997: 169, no. 139) 
A Lithuanian legend about Laume from 1961 likewise tells of a woman who found a piece of cloth stretched out for bleaching on the ground, obviously in the form of a band which she wound up like a ball of thread:

She [a woman] bent down and started rolling one up when she heard a [Laumè's] voice say: "Cut and sew from this cloth, but don't look at the end. Then it will last you as long as you live." So she took the roll of the cloth home and cut and sewed from it many years. One day she became bored and unrolled the cloth all the way to see what was inside. She didn't find anything interesting, just the end. And so ended the Laume's cloth. (Vèlius 2002: 23, Laumè's Cloth)

In all three legends, Portuguese, Slovenian and Lithuanian, "finding the end of a thread or yarn or cloth" by breaking it and thus "making" it end (Portuguese), literally "finding the end" (Lithuanian) or verbally "wishing for the end" (Slovenian), obviates the eternal winding of the yarn (cloth). This way the connection with the otherworld from which the yarn or thread is clearly coming is cut off and riches are prevented from entering this world (the golden thread becomes bloody, i.e. useless, in the Portuguese, and the cloth in the Lithuanian and thread in the Slovenian legend run out). That it is precisely the thread which makes a link to the otherworld is particularly obvious in the Portuguese legend, since breaking the thread before it is pulled up completely makes it impossible for the moura to finally release herself from her enchanted state and keeps her stuck in the liminal world, which according to traditional concepts of space already is a threshold to the otherworld.

A ball of thread in fairytales has similar symbolic value of also making a link between the worlds. In the Russian fairytale, about Prince Ivan and White Polyanin, a small ball of thread which an old man gives to Prince Ivan unwinds through the dark forest and leads Ivan in his search for the hero - in fairytales forests usually represent the hero's entrance to the otherworld ${ }^{11}$ - where his supernatural adventures begin. Similar is the function of a rope which was, however, not made of a thread, but which Ivan and White Polyanin made from strips of bull's hide; it is so long that "one end is in this world and the other is in the otherworld" (Afanas'ev 2007: 216-23; cf. Borghini 1999: 238-40).

The idea that thread or yarn can create a connection between the worlds is illustrated in a different fashion in a Croatian (from the parish of Križevci and Zagorje) record of belief from 1851 about a fairy (vila) who teaches women how to cure and help people:

[...] on every old Friday a fairy (vila) came from the heavens in order to teach women how to heal people and help them. These women have to go with un-braided hair to a green grove, and there two of them would climb 
any old tree with the fairy and while they were listening to the fairy they had to eat yarn in order to better remember what the fairy was teaching them; when they had learned, they became vilenicas. These two women in the tree, and everyone else who was listening beneath the tree, are connected by a thread from the yarn which they hold in their hands, and as long as the fairy is speaking, they have to spin together, or as the people say, pound the thread. (Those beneath the tree do not eat the yarn). Anyone who doesn't do so can't hear the fairy, and doesn't learn a thing. (Čiča 2002: 90)

The women thus become vilenicas, i.e. they are given a name that is derived from the word vila, because they acquire some of her abilities and characteristics. In order to understand at all and to better remember what the fairy taught them, the women have to eat yarn, they are connected by a thread which they hold in their hands, and at the same time they have to spin together or at least pound the thread. Clearly the connection between the world of people (women vilenicas) and the world of supernatural (vila - 'fairy') was made possible only through various activities related both to spinning and to thread.

What all the folklore material so far shows is that spinning and spun thread in folk beliefs and legends (and in fairy tales) have a role of providing linkage between the world of the living and the world of the dead, that they connect the two worlds. Since supernatural beings, by definition, dwell in-between the worlds, a frequent relation between supernatural beings and thread (ball of thread, spun yarn, spinning ...) should not strike us as unusual but rather as obvious.

\section{THREAD AND THE SOULS OF THE RESTLESS DEAD}

If thread therefore forms a connection between the world of the living and that of the dead, it should come as no surprise that thread, yarn and spinning are also attached to the souls of the dead, although I have found only a few examples of such a belief. These refer to the restless dead, who according to traditional folk beliefs cannot pass into the otherworld and are stuck in liminal space between the two worlds (cf. Vinogradova 1999: 48), just as supernatural beings are. According to the most common scholarly interpretation, supernatural beings actually evolved from the souls of various categories of dead (Vinogradova 2000: 22-26; cf. Briggs 1978: 35, cf. also 26-38).

In the French L'Évangile des Quenouilles from the middle of the 15th century one reads that, besides supernatural beings, revenants too return at night in search of a thread or in order to work on spinning wheels (Sébillot 1981: 
142-143). Similarly, two narratives, recorded at the beginning of the 21st century in the Sora Valley in Slovenia, state that the souls of the dead spin or even appear in the form of a ball of thread or wool. Thus in Spodnje Danje (Sorica), whenever people heard strange noises on the roof, they said that they were hearing the rolling of bloody balls of wool which were spun by dead sinners:

She was spinning. She kept on going up and back as if she was spinning. She spun the wool and that woman must have done something, I don't know what, so that her conscience was bothering her. [...] Whether it was some bloody crime she committed, God knows what, nobody knows. (Pintar 2007: 28-29)

Another narrative tells of a man who came back after his death in the form of a ball of thread to scare his grandson:

[...] Even in his old age, Gustelj would talk about how death came for his grandfather. He was left with his grandfather, whom he never obeyed and always annoyed. His grandfather warned him that he would come back to haunt him after he died, because he was so naughty. And he actually did. Whenever Gustelj lay on the stove at night ${ }^{12}$, there was a rustling sound in the bench by the stove and a ball of wool rolled out across the floor and disappeared through the closed window. (Pintar 2007: 28-29)

The connection of the restless souls, who for various reasons (usually untimely or violent death, suicide, sins, incorrectly performed or incomplete funeral rituals etc. - cf. Risteski 1999: 92-96; Vinogradova 1999) cannot proceed to the otherworld after their death and remain in the liminal space between the worlds, with thread, yarn, balls of wool, spinning etc. additionally indicates their "inbetween" status, as we have already seen in folk beliefs about supernatural beings.

\section{THREAD AS A BRIDGE TO THE OTHERWORLD}

Now, if a result of spinning - (balls of) thread, spun yarn - symbolises a link between the world of the living and that of the dead, as we have seen in folk legends about supernatural beings and restless dead, then it is noteworthy that we find the same idea explicitly represented in folk notions of a bridge which souls have to pass on their way to the otherworld - which can be depicted in the form of a thread.

In Thompson's Motif-index we find the motifs Bridge of thread on way to world of dead under number F152.1.7 and Rope bridge to otherworld under number F125.1.5. An old English song sung at wakes compares the bridge, 
along which souls must travel to the otherworld, to a thread: the bridge of dread, no broader than a thread (West 2007: 390).

In French folk beliefs related to the feast of Saint Cordier (the name derives from the same root as "cord") we find the same idea. If an interpretation of French folk beliefs and customs by Claude Gaignebet and Marie-Claude Florentin is to be believed, celestial rope allegedly twisted by St. Cordier on the 25th of January (the feast day of the Conversion of St. Paul, celebrated as Rope-makers' Day in France), i.e. on the day when according to their interpretation souls circulate between the worlds, creates a link between the two worlds: people and gods climb and descend on the rope (Gaignebet \& Florentin 1974: 65).

In the account of an initiation of a Nganasan shaman he describes his path during a shamanistic séance: "When I am looking for a sick man, the road is narrow like a thread [...] on this (road) you go for the breath of the man." (Tolley 2009: 43) Obviously, during the shamanistic healing performance the shaman's path leads to the otherworld, be it the upper or lower one, so here, again, we have the road to the otherworld depicted as a thread ${ }^{13}$. Similar notions about the rope leading to the sky which is being lowered specially for the shaman to climb up are found in ritual poems of Ostyak (Khanty) and Yurak (Nenets)-Samoyed shamans as well as by Yakuts (Sakhas) shamans (Elijade 1985: 178, 183).

However, hair seems to have the same function of a bridge to the otherworld as a thread does. Especially in Greek (Parpulova-Gribble 1996: 172; cf. Dundes 1996: 195) and South Slavic folklore hair is more frequently found than thread, perhaps additionally emphasising the narrowness of the passage.

According to beliefs from Serbia (several regions) Paradise is entered by crossing Hell (both interpretatio christiana of the otherworld). A long hair is laid over the pit of Hell and the souls of the dead must travel across the hair: the righteous make it across and sinners fall into Hell (Zečević 1982: 28-30). In a Serbian folk poem from the 19th century we read about St Peter's mother who would like to enter Paradise and is told by St Peter to come to Paradise along the hair - however, when she starts climbing the hair it breaks and she falls into Hell (Karađić 1969/I: 100-101, no. 208, Majka Svetoga Petra). In the village Dupljaja near Bela Crkva in Serbia, a poem was recorded in 1969 which speaks of a hair leading to the otherworld:

There is a thin hair,

Across which every soul must pass,

All pass, one cannot,

When it gets to the middle of Hell,

The thin hair breaks,

And it falls into the middle of Hell. (Zečević 1982: 29) 
Ideas about (foot) bridges, beams, and hair that the soul must cross on its way to the otherworld are frequently interwoven in Serbian, Montenegrin and Bulgarian folklore. In villages along the Danube in Bulgaria, for example, a belief was recorded that the way to the otherworld leads along a hair or a narrow footbridge (Zečević 1982: 29). Montenegrins in Kosanica say that upon death, the Archangel Michael sits on the chests of sinners, takes their souls and carries them up to heaven, and ....

[...] as soon as he comes to the first wall, he allows the soul to pass over a single strand of hair, which passes like a bridge over an enormous abyss, but it looks like a beam to people, and is attached to the other wall, on the other side of which is Heaven. If a sinful soul walks on the hair, the sins are too heavy, the hair breaks and the soul falls into Hell where devils await it and torture it. (Vukanović 1935)

A belief from Podibar, Serbia, is quite similar to the Montenegrin belief: people say that the Archangel waits for souls in the otherworld and measures their good and evil deeds, then sends the souls towards Heaven, on a path which leads across Hell. If the soul is righteous, the path across Hell seems like a wide bridge, but if the evil deeds outweigh the good it seems to be "as thin as a hair" and the soul then falls into Hell (Nodilo 1981: 523).

However, the idea of a hair (which acts as a bridge to the otherworld) is not as far from the idea of a thread as it might seem at first glance. Apart from an obvious likeness between a thread and a hair, hair was once used as fibre material for spinning and weaving. Archaeological findings show that human hair was used as a fibre material in, for example, a few objects from the 7th millennium BC site Nahal Hemar in the Judean desert (Barber 1991: 25, 30). Pieces of cloth woven from human hair were also found in a grave from the 910th centuries in Staré Město in the Czech area (Moravia) (Kostelníková 1973: $3-7)$.

Hair can also represent the material for spinning in folklore. A Lithuanian legend tells of a woman who invites "spinning goddesses" to spin flax for her. When the spinning goddesses were spinning her flax [...] the woman realised she was in trouble, because no matter how much flax she brought, it was never enough to keep them busy. She knew if they ran out of flax they would start spinning her hair [...] (Vèlius 2002: 19-20, The Spinning Goddesses).

Likewise, the equation of fibres with hair is obvious in the Lithuanian variant of the fairytale type The Household of the Witch (ATU 334). A girl observes the witch's homestead:

[...] the gates are closed with a human arm and the door with a human leg; human heads hang out on the fence; inside the house a human stom- 
ach full of blood is put on a table and human hair is bundled all over the floor. The witch asks what the girl has seen and explains the true meaning of the strange phenomena observed: the gates are closed with a bolt; the door is secured with a hasp; the heads are her pots instead; the stomach is her bowl of sauce; and the hair is flax fibres for spinning. (Racènaitè 2008: 135)

\section{THREAD AND CHILDREN}

We have seen so far that the symbolic role of spinning, thread, and yarn, lies in their providing a link between the world of the living and the world of the dead. This can be seen in spinning etc. related to supernatural beings and the restless dead who dwell in the liminal space between the worlds, but also in folk beliefs about a thread (and hair) making a bridge to the otherworld. A thread, according to traditional folk conceptions, can thus lead from the world of the living to the world of the dead as a bridge which souls pass on their way across. But the thread also leads in the opposite direction.

As Francisco Vaz da Silva has convincingly argued in his book, Archaeology of Intangible Heritage, according to archaic European mythological conceptions new souls come to this world from the world of the dead: “... new life is a recycling of soul, so that procreation involves cyclically wrenching life out of death." (Vaz da Silva 2008: 46) In Slavic folklore we sometimes find folk beliefs about newborn children arriving from the otherworld via a thread. It is perhaps not without significance that such folk notions have been recorded in Polesye, a region on the border between Belarus and Ukraine, where most archaic Slavic linguistic and folklore elements have been preserved. Typically, parents' responses, to their children's questions about their origin: Where do children come from? contain the motif of children descending from Heaven (the Christian otherworld) by a thread: God lowered [you] on a thread (Khomorsk); [He] lowered you from Heaven on a golden thread; God lowered you from Heaven on a red thread (Golubica) etc. (Vinogradova 2000: 351).

In relation to these beliefs about a thread, by which children are lowered from the otherworld to ours, one possible interpretation of the magical practices of Serbian and Turkish women, who tie threads onto their children when they are born and make knots on them ${ }^{14}$ believing that they will not give birth to another child until the knots are undone (Saintyves 1987: 88), would be to understand this praxis as a symbolic binding of the thread which could potentially allow the arrival of more children to this world. 


\section{SPINNING AND THE MAKING OF A CHILD}

In the context of spinning, the relationship between a child being born into this world and its state before birth, i.e. in the otherworld, is associated with the opposition between spun thread and un-spun wool - which again connects the symbolism of spinning and thread to the link between the worlds.

On the basis of a passage from the Old Norse saga from the 14th century, Karen Bek-Pedersen argues that the image of the wool-basket is "an image relating to birth with the wool-basket as a symbolic womb and the un-spun wool in the basket as a piece of textile that is not yet made or a person who is not yet born or fully made":

Sigurdr went to consult his mother, who was skilled in magic. He told her that the odds against him were heavy, at least seven to one. She answered: "I would have kept you for a long time in my wool basket if I knew that you would live forever, but it is fate which rules, and not where a man is from; better to die with dignity than to live with shame." (Orkneyinga Saga 11, Flateyjarbók, ca 1387-1395; from Bek-Pedersen 2008: 176)

The making of a textile would then be akin to the making of a person, a kind of a birth-process, and the wool-basket would be the space in which this work took place, namely the dyngja ${ }^{15}$ or the womb. As keeping a person inside a wool-basket is presented as an image of ensuring that he would live forever, this would, according to Bek-Pedersen, mean that what is in the wool-basket has not been born yet. So Sigurðr's mother is actually saying to him that being born means that one must eventually die and that no one who has been born can live forever (Bek-Pedersen 2008: 173-174).

Mary Kilbourne Matossian argues for the same symbolic connection between the spinning of a thread and body tissue: "Understanding the un-spun wool in the basket as a piece of textile that is not yet made or a person who is not yet born or fully made, and the making of a textile as the making of a person, a kind of birth-process, helps us understand yet another parallel: a symbolic connection between thread and body tissue." She emphasises that "in the primitive symbolism of Western Civilisation, to spin and weave is to create body tissue." (Kilbourne Matossian 1973: 331)

The idea seems, indeed, to be reflected already in some of the very oldest texts. In the Vedas, for instance, there is a notion in which, according to Martin L. West, the continuity of human life is conceived as a drawn-out thread or lengthening strip of fabric (West 2007: 380): Who set the seed in him and said, / Still be the thread of life spun out? (Atharva Veda 10.2.17) 
In Slavic folklore a mother is often represented as a distaff, but the relation between, on the one hand, spinning yarn on the spindle and, on the other hand, a child is the same nevertheless. Riddles present the distaff as an allegorical image of a mother who is spinning the thread of life, while the yarn on the spindle is considered a child growing in her womb, e.g.: The mother shrinks, the child grows. What is it? Spinning. / The mother thins out, the child grows etc. (Badalanova Geller 2004: 231).

This image, in the opinion of Badalanova Geller, also shaped the metaphorical representation of "life-span" as "yarn-spun" (2004: 231). She claims that the image of the basket is often allegorically intertwined with the image of the womb. Such a parallel is attested in Christian iconography; icon painters persisted in painting a basket full of yarn as a necessary attribute of the Virgin Mary at the moment of the Annunciation, thus emphasising an allegorical image of the Virgin as "the basket of the flesh of Christ" (Badalanova Geller 2004: 221-222). The source of this image is considered to be the apocryphal Book of James (The Protevangelium of James) from the mid-second century:

Mary took the scarlet and spun it.

And she took the pitcher and went out to draw water, and behold, a voice said, "Hail, highly favoured one, the Lord is with you, you are blessed among women." And she looked around to the right and to the left to see where the voice came from. And, trembling, she went to her house and put down the pitcher and took the purple and sat down on her seat and drew out the thread. And behold, an angel of the Lord stood before her and said, "Do not fear, Mary; for you have found grace before the Lord of all things and shall conceive by his Word." (Protevangelium $10: 2,11: 1-2)$

Badalanova Geller argues that the spinning=conceiving mythological pattern actually forms the substructure of the Annunciation to the Spinning Virgin in the Protevangelium (Badalanova Geller 2004: 231). The pattern must certainly be older than the 2nd century. Many scholars claim that Mary here (and elsewhere) actually inherited many characteristics from an ancient Mother Goddess. As Anne Baring and Jules Cashford point out, "the dynamic of this story is ... the image of Great Mother, who spins life out of herself, giving form to and clothing incarnation in the person of her son ... she weaves the great web of life in the image of a mother with a child in her womb, who weaves life into form out of her body ..." (Baring \& Cashford 1993: 559). St. Mary thus seems to have incorporated in her image and cult many of the aspects of the Great Mother Goddess who "herself spins and weaves because she is the primal embodiment of ... growth, of time, of destiny. The primordial lady spins, out of her 
own being, the thread of time and weaves it to make the tissue of things, just as a woman spins in herself the tissue of another being's flesh ... spinning and weaving are occupations proper to the Virgin Mary as the Great Mother ..." (Wilkins 1969: 96-97 from Baring \& Cashford 1993: 559). Likewise, Hilda Ellis Davidson recognises in this image "echoes brought into Christian tradition of the spinning goddess who could influence the fate of the new-born and the destiny of the world" (Davidson 1998: 115).

Even though the Protevangelium was later rejected in Western Europe, the scene is frequently portrayed in Christian iconography, especially in Byzantine art, but not exclusively - see, e.g., a disc brooch from Byzantium from about the 6th century AD; a mosaic from Santa Maria Maggiore in Rome from 432-440; an ivory relief from Castello Sforzesco in Milan from around 700; an illuminated manuscript from ca 1130-50 from Biblioteca Vaticana; an icon from the 12th century in the Tretyakov Gallery in Moscow, etc. But the motif persisted even in much later works of art, for instance in Eugène Emmanuel Amaury-Duval's Annunciation from 1860, William Adolphe Bouguereau's Annunciation from 1888, Jake William Waterhouse's Annunciation from 1914, to name but a few. All these paintings show Mary with her spindle or spinning wheel and/or a basket and a thread (cf. pictures in Baring \& Cashford 1993: 560-561; Davidson 1998: 113-115; Annunciation 2004: 5, 7, 21, 205, 209, 227; Badalanova Geller 2004: 215-234).

Just as Christian iconography relates the Virgin Mary to spinning, so it does for Eve, Mary being considered a redeemer of the First Eve (cf. Baring \& Cashford 1993: 572-574): spindle and distaff were considered classical emblems of Eve after her expulsion from Paradise, as they were of the Virgin Mary during the Annunciation. Florentina Badalanova Geller argues that "in this the image of the spinning Virgin Mary, as the Mother of Christ, together with that of the spinning $\mathrm{Eve}^{16}$ as "the mother of all living things" stands for emblems (both celestial and terrestrial) of motherhood while the act of spinning is recognised as tantamount to the act of (pro)creation." (Badalanova Geller 2004: 213, cf. also 216, 235-239)

Woman, according to the traditional European worldview, gives life and relates also to death; "the dead rejuvenate from tomb to womb, afterwards to reincarnate so as to progress from womb to tomb", and this gives a semantic bundling of tomb and womb (Vaz da Silva 2008: 75, 78), the otherworld and the womb. The wool-basket therefore represents the womb, i.e. the otherworld from which a child is yet to be born, while un-spun wool in it is related to its "before-birth" state in the otherworld. On the other hand, the thread spun represents its living existence in this world. Again, the spinning, fibres for spinning (un-spun wool, flax), and its result, a thread, are related to the link 
between the worlds since the new life, as a spun thread, actually stems from the otherworldly existence, i.e. from the un-spun wool.

\section{SPUN THREAD AND "TURNING HUMAN"}

But while spinning thread, as we have just seen, can account for creation of the child's body, it can metaphorically also represent an integration of a child into society, into its human status, into "culture" - in opposition to raw flax or un-spun wool which represents "nature". Spinning is typically understood as an activity which separates "nature" from "culture", since yarn is made into clothing, one of the most characteristic aspects of human culture (Petreska 2006: 225).

The turning motion of the spindle is therefore loaded with strong symbolism. Pieter Plas' ethno-linguistic inquiry in traditional folk culture of the Western Balkan Slavic area has shown that

... the downward movement of wool from the distaff to the spindle, while it is spun into yarn, can be conceived of as a movement from "wild" to "domestic" space." As the movement of spinning is equated with the movement of wolves from forests to people's abode, women in Kosovo were not allowed to spin in the week prior to the holiday of Saint Sava ${ }^{17}$ "lest the wolves be dragged over from the woods and find themselves around the folds". (Plas 2004: 265-266)

Since according to traditional conceptions, "wild space" (where wolves live) is equated with the otherworld, it is actually a threshold to the otherworld (cf. Radenković 1996: 47), spinning therefore represents a symbolic movement from the otherworld into this world.

Such notions about spinning, as a movement from nature to culture, from the otherworld to this one, can be applied in folk magic, for instance in the technique of "turning human". This is a necessary procedure in case a zmej(če) ('dragon/dragon child') is born. As is known by Macedonians, Bulgarians and Serbs, $z m e j(c ̌ e)$ is a child born with special signs who is predestined for the role of a mediator between the community and the otherworld. But for him to be able to function as a mediator protecting the world of culture, he needs to go through initiation rites first. Here is how a Bulgarian initiation rite of a magician related to spinning and weaving is described:

If after a pregnancy of 11 months ${ }^{18}$ a zmejče ('dragon child') is born with a tail and wings, twelve maidens, or nine old women, need to weave a shirt for it in one night. They tear the hemp using pine cones, spinning 
and weaving it in complete silence. When finished, they put the shirt on the baby in order to cover its tail and wings. If the baby is not dressed in a shirt like this, it will not develop into a $z m e j$ ('dragon') and thus will not become a patron saint to the village." (Pócs 2008: 97)

While, according to Pócs, the raw technique of tearing the hemp with pine cones is a sign of the potential mediators' bond with nature, they must, in order to successfully fight the world of demons, become assimilated into a properly human existence as well, to become members of human society and represent the world of culture. Éva Pócs argues that their assimilation into human society happens exactly when they go through the act of the female group weaving the shirt for him. The technique of "turning human" therefore shows that, of the basic working processes of human culture, it is mainly spinning and weaving ${ }^{19}$ that "play a vital role in taming or ennobling the demonic world of nature and the initially demonic aspects of human nature and in protecting human culture". (Pócs 2008: 97-98)

Spinning is a means of "humanisation" not only in magic and folk beliefs but also in fairy tales. In the Grimms' The Nix of the Mill-Pond (ATU 316), for instance, the heroine restores a bewitched creature to his normal human condition by spinning flax on a golden spinning wheel. As Maria Tatar claims "spinning, weaving, and sewing ... appear to have the power to turn animals into men and to domesticate the most ferocious beasts". (Tatar 1987: 114-115)

\section{THREAD AND FATE}

Spinning is therefore related not only to the existence of man in this world, as we have seen in relation to the making of a child's body, but also to the acceptance of a child into "culture", with which "this world" is usually more or less synonymous. However, not only was the child's body conceived as being spun, but also his/her fate, which was bestowed upon the child at birth. Just like the skin was, according to traditional conceptions, wrapped around the body of a child the same way as thread is wound around a spindle, as was argued above, fate was also considered to be wrapped around a man by the Greeks who allegedly conceived fate and phases of fortune (such as misfortune, marriage, age, disease, death etc.) as threads spun by the gods or fates and given by them to men in the form of a wreath of wool, a thread or a bond (Onians 1954: 376, 378, 395, 429). In many places the expression "thread of life" means man's fate.

We find beliefs in supernatural females attending the birth of children to determine their fate throughout Europe. Indeed, M. L. West claims that these 
beliefs go back to the deepest level of Indo-European tradition. More importantly, these female beings very often spin: the Hittite goddesses Papaya and Isdustaya spin the threads of fate (West 2007: 380). In the Odyssey Odysseus [...] shall suffer whatever fate (Aisa) and the dread spinners spun with their thread for him at his birth, when his mother bore him (Odyssey 7.197-198; cf. also Odyssey 11.139). In the Iliad the same expression is used with Aisa or Moira as the subject: [...] but thereafter shall he suffer whatever Fate (Aisa) spun for him at his birth, when his mother bore him (Iliad 20.126-8); On this wise for him did mighty Fate (Moira) spin with her thread at his birth (Iliad 24.209; cf. also Iliad 24.525). Hesiod writes about a trio of Moirae who give mortal men both good and ill (Theogonia 904-906) and who were imagined to be spinners ${ }^{20}$ : one carries a distaff, the second a spindle and the eldest scissors; their names were Clotho, Lachesis and Atropos (Davidson 1998: 98; West 2007: 380-381).

As Richard Broxton Onians emphasises, the activities of fates were the assigning of the portion of un-spun wool (by Lachesis ${ }^{21}$ ), the spinning (Clotho) and lastly the binding or weaving of it (Atropos) - the fate has thus been something spun, which has afterwards been inflexibly fastened to the person in a binding or weaving process (Onians 1954: 416-417).

The Parcae, Roman goddesses of fate, were supposed to be present at childbirth, spinning the threads of fate: This was the destiny for sure that the Parcae, who spun the fatal thread, twice ordained for you, at your double birth. (Tristia 5.3.25) and Petronius mentions the three Fates (Parcae), spinning their golden threads (Satyricon 29.6; cf. West 2007: 381). When, however, they were assimilated with the Latin goddess Dea Parca, who is traditionally associated with birth, and the goddess Fata Scribunda, the spindle usually disappeared as their attribute - and in its place a book or a globe appears (Cottica 2004: 191).

The question is whether we can also speak about spinning in connection with the nornir, the female beings who play a similar role in Scandinavian mythology - beings deciding fate and are at the same time related to birth and death: they give life, but also take it (Belmont 1971: 176; Bek-Pedersen 2007b: $22-37,63)$. Although they generally have the reputation of spinners, there are no clear and unambiguous data about them spinning or weaving in Old Norse mythological texts (Simek 2007 (1984): 237; Bek-Pedersen 2007a, 2007b). However, in one (and it seems the only) instance ${ }^{22}$ we can read in the Poetic Edda about the norns attending the birth and shaping the life of a child, operating the threads or strands:

Night fell on the place, the Norns came,

Those who were to shape fate for the prince;

They said the prince should be most famous,

And that he'd be thought the best of the warriors. 
They twisted very strongly the strands of fate,

[...]

They prepared the golden thread

And fastened it in the middle of the moon's hall.

(The First Poem of Helgi Hundingsbani 2-3, The Poetic Edda; cf. Davidson 1998: 119-120; cf. West 2007: 382).

Similar notions about fates spinning are also frequent in 19th and 20th century European folklore. In Greek folklore, the fates figure as three old women - at least one of which is always engaged in spinning, one of the remaining two sometimes bears a book wherein she records the decrees they jointly utter, while the other carries a pair of scissors wherewith to cut the thread of life at the appointed time. Sometimes, however, the last two spin, and in these cases one of them carries a basket of wool or a distaff and the other fashions the thread (Lawson 1964: 123-124). Alternatively, Clotho spins the thread of life, Kalomoira apportions luck, and Kakomoira misfortune (Schubert 1982: 92).

The Latvian láimas, who appear most often in mythological songs (usually there is just one, but sometimes there are three), determine a child's life, and the involvement of spinning imagery is obvious from the following stanza:

Laima, Laima for the boy,

Who is born to the world!

For him Laima twisted the flaxen thread,

Steeping it in silver.

(LD 1176=Jonval 1929: no. 774, from West 2007: 384)

Similarly, the Lithuanian tale recorded in 1839 tells about the deives valdytojos ('ruling deities') who seem to create as well as end men's life:

The first one spun the lives of men out of a distaff given her by the highest god, the second set up the warp, the third wove in the woof, the fourth told tales to tempt the workers to leave off, for a cessation of labour spoilt the web, the fifth exhorted them to industry, and added length to the life, the sixth cut the threads, the seventh washed the garment and gave it to the most high god, and it became the man's winding-sheet. (Grimm 18821888/I: 416, note 2 , from 1839)

Slavic folklore, too, often represents spinning fates. The following narrative about the fates (here called parkas instead of the more common Slovenian rojenice or sojenice) in the Gorenjska region, Slovenia, was recorded in the 19th century: 
Of them they say there are three, who when a person is born come into the house in order to decide their fate. A loaf of bread must always be left on the table for them on this occasion. One of the parkas starts spinning the thread of life, the second spins further, and the third cuts the thread upon the person's death. The names of these parkas are not given. (Matevž Ravnikar-Poženčan 2008: 238)

Idiomatic expressions in the Slovenian language also indicate the connection between spinning and fate, e.g. the proverb "to spin the threads of a man's fate" (presti niti človekove usode) figuratively means 'to decide a man's fate' (SSKJ 1986/3: 138).

Yarn is, according to Macedonian and Bulgarian beliefs, spun by fates called orisnice, narečnice and rečenica. The spindle and distaff are understood to be their attributes, they are said to decide fate while spinning, and the length of the thread spun around the child's head embodies his or her destiny ${ }^{23}$ (Badalanova Geller 2004: 231-235). In a legend from the Ohrid area in Macedonia, the fates (narečnice) are depicted as three women sitting in front of the fireplace and spinning the thread of life: the first and the second one spin, and the third one cuts the thread with her scissors after the three of them jointly have made their prediction (Petreska 2006: 225). A monument ${ }^{24}$ in Orahovac, to the northeast of Prilep in Macedonia, shows three women in national costume with their left hands raised and right hands lowered and holding a spindle - they are pictured the same way as Bulgarian orisnice and seem to represent the fates (Schubert 1982: 90-91, note 12). On the other hand, Irina Sedakova found only little evidence of this connection in the Bulgarian archives and fieldwork and claims that it is a rare belief - there is, however, a narrative about the first orisnice who gathered sun rays, gave them to the second one who spun a thread out of them and predicted fate while the third, the oldest one, cut the thread. There are also legends indicating that three orisnice play with a ball of thread and unwind the thread of life (Sedakova 2007: 209-210).

Traces of belief that the fates spin the life thread of newborns can also be found in the legends from the former Czechoslovakia. The length of the golden threads represents the length of a person's life, whose end is determined by the eldest fate (sudička) who cuts the thread (Brednich 1964: 184). The Czech folklorist Alexandra Navrátilová writes that the belief in fates spinning the fate of a man, with a thread symbolising the length of a man's life, was very well known in the Czech state; records from the 19th century mention that people also set out spinning wheels and scissors so that the fates would decide a more pleasant fate for the child (Navrátilová 2004: 53). 
According to Ukrainian belief recorded in the 1930s and 1940s the fates (sudci) are playing with a ball, unwinding the thread of life (Archive of St. Romansky, Univ. of Sofia ${ }^{25}$ ).

Among the Romanians, the eldest of the fates, Ursitoarea, was believed to spin the thread of life, the middle one, Soartea, to foretell the events in the life of the newborn and the third, Moartea, to decide the moment of death by cutting the thread. According to another record of belief the first, Ursitoarea, holds a distaff and spins on the wheel, the second, Soartea, spins the thread, and the youngest, Moartea, cuts the thread of life with her scissors (Brednich 1964: 171).

\section{THREAD AND DEATH}

Spinning and thread are therefore related to notions about birth, the creation of a body and the fate of a newborn child who, according to traditional folk beliefs, is spun from un-spun wool, which symbolises a child's prior existence in the otherworld, in a wool basket, or womb. As such, spinning a thread or child's body from un-spun wool actually means creating a link which stems from the otherworld (un-spun wool) into this world (spun thread). The spinning continues while a man is still alive. When the spinning stops, a man dies, the length of the thread which is to be spun being, as we have seen in numerous beliefs around Europe, past and present, determined by spinning fates at birth.

Beliefs about a thread of life which is cut by the third fate can also be found in language. Many idioms directly connect the end of a thread with the end of life, i.e. with death. The Slovenian language knows sayings such as "to cut/to break the thread of life" (prestriči / pretrgati nit življenja) - figuratively: to cause death; or "his/her life is hanging by a thread" (njegovo / njeno življenje visi na nitki) which means that his or her life is severely threatened, he/she is very ill (SSKJ 1986/3: 138). Ukrainians (from Galicia) similarly say about the death of a person: "his thread is being torn" (urvalas' my nitka) (Il'kevich 1841: 9726).

In French, expressions such as "to be at the end of his roll" (être au bout de son rouleau), "to be at the end of the length of his ball of thread" (être au bout de sa doitte (aiguillée de fil)) (l'Ille-et-Vilaine; Van Gennep 1998/1: 574) have the same meaning.

When someone dies the Greeks say: "His spindle is wound full" (Kilbourne Matossian 1973: 331). John Cuthbert Lawson argues that Greek expressions such as "his spindle is wound full", "his thread is cut" or "his thread is finished" (meaning 'to die') seem to imply the idea that the fates apportion to each man 
at birth a mass of rough wool from which they go on spinning day by day till the thread of life is completed (Lawson 1964: 124) - which is well in accordance with what was stated above.

When the spinning stops and the winding of thread around the body is completed, death ensues. ${ }^{27}$ Death is therefore a (start of a) process of (drying ${ }^{28}$ or) unwinding the thread of life from the spindle of the body or spine (Kilbourne Matossian 1973: 331-332). A human life from birth onwards was, according to traditional conceptions, conceived as a continuous winding of bands of thread or body tissue and fortunes around a person, whereas death, on the contrary, was conceived as an unwinding. Thus, it is understandable that the semantics of the verb 'to wind' (viti) in Slavic languages includes both meanings: it has the connotation of fertility, growth and birth as well as of death. The meanings of this verb are associated with the positive, with growth, the embryo (beginning), proliferation, and development, and on the other hand with the negative, impure forces and destructive aspects (Plotnikova 1996), i.e. with life and death.

In Kilbourne Matossian's interpretation, a Russian healing incantation is an expression of the notion that the process of passing away is equated with the unwinding of the thread of life from the spindle of the body. A stream of blood coming from a wound is, according to her, analogous to this thread:

On the sea, on the ocean, on the island of Buyan on a little white stone sits a beautiful girl, re-spinning silk on a crooked spindle. Spindle, turn, thread, break, and you blood, go away! (A. T. Popov, Russkaia narodnobytovaia meditsina, St Petersburg 1903: 24729, from Kilbourne Matossian 1973: 333)

The notion that death means the beginning of the unwinding of the thread from the spindle of the human body might also explain the symbolism of the unwinding of balls of wool or thread in funeral rituals: at the beginning of the 20th century, people in northern Moldavia (in the vicinity of Dorohoi) carried coffins to the cemetery by walking behind a wrapped-up white woollen cloth, which they kept unwinding from the house to the graveyard (Stahl 1987: 218).

In the context of the interpretation presented here, i.e. that the winding of thread represents the continuity of a life cycle from birth onwards while unwinding of the thread means dying, i.e. entering into the world of dead, Theseus' unwinding of the thread given to him by Ariadne when he enters the labyrinth, from a well known Greek myth, can be understood as his entering the otherworld. Craig Wright actually argues that the labyrinth on Crete was indeed understood as the otherworld (2001: 15). On the other hand, his rewinding of the string and returning from the labyrinth after slaying the Minotaur 
can be understood as his subsequent re-birth to the world of the living. Similarly, Penelope's weaving of a shroud for Laertes where she un-weaves at night what she has woven during the day (Odyssey 2.93-100, 19.137-156, 24.129148) can be understood as her attempt to undo time. ${ }^{\mathbf{3 0}}$

As stated above, according to traditional European worldview, "all life comes from death, and every death foreshadows renewal" which can be understood as an eternal circulation of souls between this world and the other, i.e. what Francisco Vaz da Silva calls "rounds of souls" (2008: 82, 73-75; cf. also Barstow 1983: 12). If un-spun wool is related to that world and the spun thread to this one, we may perhaps speculate that people conceived the thread that unwinds upon death as ultimately decaying once again into raw, unprocessed material, un-spun wool - just as a body decays after death - from which a new thread, i.e. body, is once again spun upon each subsequent birth. We can hardly expect to find direct evidence for such a claim, although such a notion would seem reasonable in the context of traditional ideas about a continuous rotation of souls from this to that world and vice versa. With this in mind, the curious motif of a snake lying on wool on top of tree roots in Belorussian incantations would seem understandable:

On a flat plain by an azure sea stands a broad leaf oak. Beneath it old sheep, sheep from last year, black wool. On this wool lies a snake. (Romanov 1894: 108, no. 280, from Katičić 2008: 154)

On a flat plain there is an apple tree, beneath this apple tree is a nest made from the fleece of a black ram; and in this nest is a snake. (Romanov 1894: 181, no. 93, from Katičić 2008: 154)

In the opinion of contemporary researchers of Slavic mythology the snake is an emanation of the pagan Slavic god of the otherworld, Veles or Volos. The god of the otherworld thus lies in the otherworld on un-spun wool at the foot of a tree-axis mundi. A similar notion is found in the Hittite ritual text of the god Telepinus (Katičić 2008: 154; cf. also Toporov 2002: 40-41). There is also an etymological connection between the name of a god and the word for wool: the Russian word volosen', closely associated with Veles/Volos, means a long strand of sheep's wool, woollen yarn but also a devil or an evil spirit - into which the pagan god of death was degraded upon the rise of Christianity (cf. Toporov 2002: 41).

Conceptions that link un-spun wool with the otherworld could further clarify the widespread custom of laying balls of un-spun wool ${ }^{31}$ on graves in SouthEastern Europe - thus symbolically that to which the souls of the dead return and turn into. People say that the soul "hides" in them, that it is "resting" there, that it is "protected" there, that it is "sleeping" there, it "makes a nest", 
since the soul is "as light as flax". All of these objects are intended solely for the dead and nobody touches them. Paul Henri Stahl underlines that the frequency with which people affirm that these objects are necessary is surprising. Balls of wool on crosses and spruce trees also decorate the graves in the southern tracts of the Hunedoara region of Romania, and Bulgarians throw balls of wool onto places where someone has died (Đaković 1983; Stahl 1987: 218; Đorđević 2002: 425).

\section{CONCLUSION}

The material presented in this paper shows that according to the traditional European conceptions, spinning, the material for spinning (fibres - un-spun wool) and the results of this activity (thread, yarn) bear important symbolic meanings related to the basic aspects of human existence - birth, fate and death. Spinning is a means of entering and/or exiting this world. Moreover, it marks the connection between the world of the living and the world of the dead in various ways - indicating the transition, the link and the liminal space between the two worlds. However, while un-spun wool bears a symbolic reference to the otherworld, spinning and its result, a thread, seem to be trademarks of an existence in this world.

While I do not claim for such symbolism to be universal, it nevertheless seems obvious that - by comparing data from different sources - one comes to similar conclusions regarding the symbolic meanings of spinning. The fundamental ideas about spinning seem to have had an enduring existence in the European traditional worldview, even though they have been verbalised and presented in many different ways, and in many different places and times. Yet, as Francisco Vaz da Silva beautifully phrased it - and let me conclude with his words: "... one can perceive the structure of the universe in a grain of sand, even though no two grains are ever alike.” (Vaz da Silva 2003: 350)

\section{ACKNOWLEDGEMENTS}

I would like to thank the Humboldt Foundation for their financial support during my research stay at the University of Mannheim in 2008, where I gathered the literature for the present paper and where it started to take shape. 


\section{NOTES}

1 Elizabeth Barber suggests that the more primitive methods of turning bast into thread were known even before, i.e. already in the Upper Paleolithic era (1991: 3950 ).

2 This goes also for weaving - spinning and weaving in their symbolical connotations sometimes overlap, as weaving is in a way a natural extension of spinning and generally follows on from spinning. Thread must first be spun so that it can afterwards be woven into a fabric (Barber 1991: 9; West 2007: 385-386; cf. also Kilbourne Matossian 1973: 331).

${ }^{3}$ No special date or place where the poem was recorded is indicated. However, Karađić died in 1864 so the poem must have been recorded before that. The poem was sung on the kraljice holiday which is usually performed on St George's or St Nicholas' Day.

4 This was published in his collection of fairytales Severnye skazki (in translation: Northern tales) from Arkhangelsk and Olonetsk provinces.

5 The author does not give a German name of a supernatural being.

${ }^{6}$ The author does not tell when this should be done, but one can assume whenever they stopped using it.

${ }^{7}$ In the role of the "Spinnstubefrau" we can find Perchta (Pehtra/Perhta/Pehtra baba/ Pehtrna/Pirta/Pehta/ Percht/Berchta ...), in Germany also Frau Holle or Holda, Stampe/Stempe/Stempa, in Switzerland Frau Saelde, in Slovenia Kvatrnica, Torka or Torklja. The Italians know a similar being named Befana, the French have Tante Airie, Swiss Sträggele, Chrungele, etc. We furthermore find them under several different names in central Asia, from Iran through Tajikistan to the basin of the lower flow of the Syr Darya and Amu Darya rivers (cf. Kuret 1997; 1989/II: 458).

8 The difference between the vila and rojenica is not always clear.

9 For the references of the variants of this type of Slovenian legends see Kelemina 1997: 314 .

${ }^{10}$ Men in the Slovenian countryside often helped women to wind the thread.

${ }^{11}$ In medieval European folk beliefs, e.g., forests were associated with otherworldly creatures like those of the Wild Hunt, the procession of spirits or ghosts who roamed around. Wild men and women, part human, part animal and part spirit, were also believed to roam medieval forests (Russell 1999: 49-50).

${ }^{12}$ In the Slovenian countryside it used to be customary for children to sleep on the stove at night (which the householder stopped heating in the evening, but it stayed warm until morning).

13 The report in Tolley is cited from Popov who published it in 1968; he cited the Russian original which has never been published (cf. Tolley 2009: 36).

${ }^{14}$ Saintyves interprets the thread in this case as a symbol of fate (cf. below).

${ }^{15}$ A certain building or room where spinning and weaving was done in ancient Scandinavia. 
${ }^{16}$ For a picture of the spinning Eve, see for instance Badalanova Geller 2004: 237-238.

${ }^{17}$ In some places, the so-called wolf holidays begin around St. Sava's day; these holidays constitute a period when wolves are supposed to be most dangerous to people (for more on wolf holidays in the Balkans see Mencej 2009).

${ }^{18}$ There is no explanation for how to understand such a long pregnancy.

${ }^{19}$ Besides cooking and baking.

${ }^{20}$ However, as Daniela Cottica states, spinning symbolism was not originally included in the concept of the Moirae; they absorbed it or appropriated it from older goddesses of fate known in Minoan and Mycenaean mythology (Cottica 2004: 185-6).

${ }^{21}$ In Homer it is otherwise most often Zeus who spins and allots fate (cf. Onians 1954: 410).

${ }^{22}$ Karen Bek-Pedersen finds the evidence rather suspicious (2007a: 4-5).

${ }^{23}$ Probably meaning a life-span.

${ }^{24}$ The author gives no information on the type and the age of the monument.

${ }^{25}$ I would like to thank Irina Sedakova for this information (personal communication May 16th 2011).

${ }^{26}$ I would like to thank Irina Sedakova for the information (personal communication, May 16th 2011).

${ }^{27}$ The same also holds for weaving: "First the warp threads are wound, their length symbolises the length of life. The wool threads symbolise the vicissitudes of a lifetime. When the weaving stops, death ensues. The resulting cloth is a shroud or winding sheet. This winding sheet, originally a prediction of man's coming experience woven by the fate goddess, is now the history of the man's life." (Kilbourne Matossian 1973: 331-332)

${ }^{28}$ A well know Indo-European as well as Semitic notion relates death to dryness, draught, drying (for a very good presentation of these beliefs, see for instance Dundes 1980: 93-133, Wet and Dry, the Evil Eye).

${ }^{29}$ I could not get the original source of this particular incantation but the incantions of the same type -A thread tears apart, blood stops - are frequent in Russian tradition, and more seldom in Ukrainian and Belarus tradition (cf. Agapkina 2010: 350-351).

${ }^{30}$ For a different interpretation see Lowenstam 2000. One of the possible interpretations, offered by Steven Lowenstam, also partially coincides with this interpretation, i.e. that "at the deeper level the shroud has always been destined for suitors. As Penelope wove, their death came closer, and as she undid her work their lives extended". (Lowenstam 2000: 341)

${ }^{31}$ However, people also lay cloth, handkerchiefs, tablecloths, napkins, clothing, or linens on the graves. 


\section{REFERENCES}

Afanas'ev, Aleksander N. 1994 (1868). Poeticheskie vozzrenija slavjan na prirodu. [Poetic Attitudes towards Nature among the Slavic People.] Vols. 2, 3. Moscow: Indrik.

Afanas'ev, Aleksander N. 2007. Ruske pravljice. [Russian Fairytales.] Transl. by L. Dejak. Ljubljana: Mladinska knjiga.

Agapkina, Tatiana A. 2010. Vostochnoslavianskie lechebnye zagovory v sravnitel'nom osveshchenii: siuzhetika i obraz mira. [East Slavic Healing Charms from the Comparative Point of View.] Moscow: Indrik.

Annunciation 2004. Boston: Phaidon Press.

Atharva Veda, http://www.sacred-texts.com/hin/av/av10002.htm, last accessed on 1 August 2011.

ATU $=$ see Uther

Badalanova Geller, Florentina 2004. The Spinning Mary: Towards the Iconology of the Annunciation in the Slavonic Tradition. Cosmos, Vol. 20, pp. 211-260.

Barber, Elizabeth J. Wayland 1991. Prehistoric Textiles: The Development of Cloth in the Neolithic and Bronze Ages (with Special Reference to the Aegean). Princeton: Princeton University Press.

Baring, Anne \& Cashford, Jules 1993. The Myth of the Goddess: Evolution of an Image. London: Penguin Books.

Barstow, Anne L. 1983. The Prehistoric Goddess. In: C. Olson (ed.) The Book of the Goddess Past and Present: An Introduction to Her Religion. USA: Waveland Press.

Bek-Pedersen, Karen 2007a. Are the Spinning Nornir just a Yarn? Viking and Medieval Scandinavia, Vol. 3, pp. 1-10.

Bek-Pedersen, Karen 2007b. Nornir in Old Norse Mythology. PHD Dissertation. The University of Edinburgh (manuscript).

Bek-Pedersen Karen 2008. Weaving Swords and Rolling Heads. A Peculiar Space in Old Norse Tradition. In: M. Mencej (ed.) Space and Time in Europe: East and West, Past and Present. Ljubljana: Oddelek za etnologijo in kulturno antropologijo.

Belmont, Nicole 1971. Les signes de la naissaince, Études des représentations symboliques associés aux naissances singulières. Paris: Librarie Plon.

Borghini, Alberto 1999. Il gomitolo nel folklore: linee per una tipologia. Una fiaba russa e l'antico racconto di Teseo nel labirinto cretese. Studia Mythologica Slavica, Vol. 2, pp. 233-243.

Brednich, Rolf Wilhelm 1964. Volkserzählungen und Volksglaube von den Schicksalsfrauen. Folklore Fellows' Communications 193. Helsinki: Academia Scientiarum Fennica.

Briggs, Katharine M. 1978. The Vanishing People:A Study of Traditional Fairy Beliefs. London: Batsford.

Cardigos, Isabel 2008. The Enchanted Calendar of Moorish Women. In: M. Mencej (ed.) Space and Time in Europe: East and West, Past and Present. Ljubljana: Oddelek za etnologijo in kulturno antropologijo.

Catháin Ó Séamas 1995. The Festival of Brigit. Celtic Goddess and Holy Woman. Dublin: DBA Publications.

Cottica, Daniela 2004. The Symbolism of Spinning in Classical Art and Society. Cosmos, Vol. 20, pp. 185-210. 
Čiča,Zoran 2002. Vilenica i vilenjak. Sudbina jednog pretkršćanskog kulta u doba progona vještica. [Vilenica and Vilenjak. The Destiny of a pre-Christian Cult in the Period of Witch-Craze.] Zagreb: Institut za etnologiju i folkloristiku.

Davidson, Hilda Ellis 1998. Roles of the Northern Goddess. London \& New York: Routledge.

Devlin, Judith 1987. The Superstitious Mind: French Peasants and the Supernatural in the Nineteenth Century. New Haven \& London: Yale University Press.

Dundes, Alan 1980. Interpreting Folklore. Bloomington: Indiana University Press.

Dundes, Alan 1996: The Ballad of "The Walled-Up Wife". In: A. Dundes (ed.) The Walled-Up Wife: A Casebook. Madison: The University of Wisconsin Press.

Đaković, Branko 1983. Prilozi u grob na području Jugoslavije. [Grave Offerings in Yugoslavia.] Zagreb: Department of Ethnology. M.A. thesis (manuscript).

Đorđević, Tihomir R. 2002. Životni krug: Rođenje, svadba $i$ smrt u verovanjima i običajima našeg naroda. [Life Cycle: Birth, Wedding and Death in Beliefs and Customs of Our People.] Niš: Prosveta.

Elijade, Mirča (=Eliade Mircea) 1985. Šamanizam i arhajske tehnike ekstaze. [Le chamanisme et les techniques archaïques de l'extase.] Novi Sad: Matica srpska

Farrell, Dianne E. 1993. Shamanic Elements in Some Early Eighteenth Century Russian Woodcuts. Slavic Review, Vol. 52, No. 4, pp. 725-744.

Gaignebet, Claude \& Florentin, Marie-Claude 1974. Le Carnaval. Essais de mythologie populaire. Paris: Payot.

Grimm, Jacob 1882-1888. Teutonic Mythology. London: George Bell \& Sons.

Iliad = Homer 1947. The Iliad. Vol. II. Transl. by A. T. Murray. Cambridge \& London: William Heineman, Harvard University Press.

Il'kevich, Grigorii 1841. Galitskie pripovedki $i$ zagadki. [Galician tales and riddles.] Collected by Grigori Il'kevich. U Vjadni.

Jonval, Michel 1929. Les chansons mythologiques lettones. Riga \& Paris: Librairie Picard.

Karađić, Vuk S. 1969. Srpske narodne pjesme. [Serbian Folk Poems.] I-IV. Belgrade: Državna štamparija.

Karađić, Vuk S. 1972. Etnografski spisi. Sabrana dela Vuka Karađića. [Ethnographic Essays. Collected Works of Vuk Karađić.] Belgrade: Prosveta.

Katičić, Radoslav 2008. Božanski boj. Tragovima svetih pjesama naše pretkršćanske starine. [Divine Fight. On the Traces of Sacred Poems of Our pre-Christian Antiquity.] Zagreb, Mošćenička Draga: Katedra Čakavskog sabora Općine Mošćenička Draga, Odsjek za etnologiju i kulturnu antropologiju Filozofskog fakulteta Sveučilišta u Zagrebu.

Kelemina, Jakob 1997 (1930). Bajke in pripovedke slovenskega ljudstva. Z mitološkim uvodom. [Myths and Legends of Slovenian People. With a Mythological Introduction.] Bilje: Studio Ro.

Kilbourne Matossian, Mary 1973. In the Beginning, God Was a Woman. Journal of Social History, Vol. 6, No. 3, pp. 325-343.

Kostelníková, Marie 1973. Velikomoravský textile v archeologickýh nálezech na Moravě. [The Textile from the Great Moravia in Archaeological Findings in Moravia.] Studie archeologického ústavu československé akademie věd v Brně, svazek 4. Prague: Academia Praha. 
Krinichnaia, Neonila A. 1995. Nit'zhizni: reministsentsii obrazov bozhestvennoi sud'by $v$ mifologii, fol'klore, obriadakh i verovaniiakh. [The Thread of Life: Reflections of Divine Fate in Mythology, Folklore, Folk Beliefs.] Petrozavodsk: Izdatel'stvo petrzavodskogo universiteta.

Kropej, Monika 2008. Od ajda do zlatoroga. Slovenska bajeslovna bitja. [From Ajd to Zlatorog. Slovenian Supernatural Beings.] Celovec: Mohorjeva družba.

Kuret, Niko 1989. Praznično leto Slovencev I, II. [Festive Year of the Slovenians I, II]. Ljubljana: Družina.

Kuret, Niko 1997. Opuscula selecta. Poglavja iz ljudske kulture. [Opuscula selecta. Chapters from Folk Culture]. Ljubljana: Slovenska Akademija Znanosti in Umetnosti.

Lawson, John Cuthbert 1964. Modern Greek Folklore and Ancient Greek Religion. A Study in Survivals. New York: University Books.

Lowenstam, Steven 2000. The Shroud of Laertes and Penelope's Guile. The Classical Journal, Vol. 95, No. 4, pp. 333-348.

Maksimov, Sergei 1989 (1903). Nechistaia, nevedomaia i krestnaia sila. [Impure, Unknown and Christian Power.] Moscow: Kniga.

Mencej, Mirjam 2009. Wolf holidays among Southern Slavs in the Balkans. Acta Ethnographica Hungarica, Vol. 54, No. 2, pp. 337-358.

Mencej, Mirjam 2010. A fonástabut megsértők büntetői Szlovéniában. [Mythical Beings Sanctioning the Breaking of Taboos on Spinning.] In: Pócs Éva (ed.) Mágikus és szakrális medicina. Vallásetnológiai fogalmak tudományközi megközelítésben. (Tanulmányok a transzcendensröl VII.) [Magical and Sacred Medical World. Religious ethnological concepts in multidisciplinary approach. (Studies on the transcendent VII).] Budapest: Balassi Publishing House, pp. 154-183.

Navrátilová, Alexandra 2004. Narození a smrt v české lidové kultuře. [Birth and Death in Czech Folk Culture.] Prague: Vyšehrad.

Nodilo, Natko 1981 (1885-1890). Stara vjera Srba i Hrvata. [Ancient Faith of Serbs and Croats.] Split: Logos.

Onians, Richard Broxton 1954. The Origins of European Thought about the Body, the Mind, the Soul, the World, Time, and Fate. Cambridge: Cambridge University Press.

Odyssey $=$ Homer 2002-2003. Odyssey. Books 1-12, 13-24. Transl. by A. T. Murray. Cambridge \& London: Harvard University Press.

Parpulova-Gribble, Lyubomira 1996. The Ballad of "The Walled-Up Wife": Its Structure and Semantics. In: A. Dundes (ed.) The Walled-Up Wife: A Casebook. Madison: The University of Wisconsin Press.

Petreska, Vesna 2006. Demons of Fate in Macedonian Folk Beliefs. In: G. Klaniczay \& E. Pócs (eds.) Christian Demonology and Popular Mythology II. Budapest \& New York: CEU Press.

Pintar, Ana 2007. Verovanja, šege in navade ob smrti ter ljudske povedke o smrti v Sorici in okoliških vaseh. [Beliefs and Customs Related to Death and Folk Legends about Death in Sorica and Neighbouring Villages.] Seminar paper. Ljubljana: Department of Ethnology and Anthropology (manuscript).

Plas, Pieter 2004. Falling Sickness, Descending Wolf: Some Notes on Popular Etymology, Symptomatology, and 'Predicate Synonymy' in Western Balkan Slavic Folk Tradition. Zeitschrift für Slawistik, Vol. 3, pp. 253-272. 
Plotnikova, Anna A. 1996. Slav. *viti v etnokul'turnom kontekste. In: T. A. Agapkina (ed.) Kontsept dvizheniia v iazyke i kul'ture. [The Concept of Movement in Language and Culture.] Moscow: Indrik, pp. 104-113.

Pócs, Éva 1999. Between the Living and the Dead. Budapest: Central European University Press.

Pócs, Éva 2008. Concepts of Time and Space in European Werewolf Mythologies. In: M. Mencej (ed.) Space and Time in Europe: East and West, Past and Present. Ljubljana: Oddelek za etnologijo in kulturno antropologijo.

Protevangelium 1993. In: The Apocryphal New Testament: A Collection of Apocryphal Christian Literature in an English Translation Based on M. R. James. Edited by J. K. Elliott. Oxford: Clarendon Press.

Racènaitè, Radvile 2008. The Concept of the Inverse World in Lithuanian Folklore. In: M. Mencej (ed.) Space and Time in Europe: East and West, Past and Present. Ljubljana: Oddelek za etnologijo in kulturno antropologijo.

Radenković, Ljubinko 1996. Simbolika sveta u narodnoj magiji južnih Slovena. [The Symbolism of World in Folk Magic of Southern Slavs.] Niš: Prosveta, Balkanološki institut SANU.

Ravnikar-Poženčan, Matevž 2008. Manuscript, National and University Library, Ms 483, Vol. IX. Printed in Kropej.

Risteski, Ljupčo S. 1999. The Concept of Death in the Folk Culture of Macedonians. Etnolog, Vol. 9, No. 1, pp. 87-98.

Romanov E. R. 1894. Belorusskij sbornik 5. [Belorussian Miscellany.] Vitebsk.

Rumpf, Marianne 1976. Spinnstubefrauen, Kinderschreckgestalten und Frau Perchta. Fabula, Vol. 17, No. 1, pp. 215-242.

Russell, Jeffrey B. 1999. A History of Witchcraft: Sorcerers, Heretics and Pagans. London: Thames \& Hudson.

Saintyves, Pierre 1987. Les contes de Perrault et les récits parallèles (leurs origines); En marge de la légende dorée: Songes, miracles et survivances; Les reliques et les images légendaires. Paris: Robert Lafont.

Satyricon $=$ Petronius 1913. Satyricon . Ed. by Michael Heseltine. London \& Cambridge: Heinemann, Harvard University Press.

Schubert, Gabriella 1982. Uloga suđenica u porodičnim običajima balkanskih naroda. [The Role of Fates in Family Customs of Balkan Peoples.] Makedonski folklor, Vol. 29-30, pp. 89-95.

Sébillot, Paul 1981. Légendes et curiosités des métiers. Marseille: Laffitte.

Sedakova, Irina A. 2007. Balkanskie motivy v jazyke i kul'ture bolgar. [Balkan Motifs in the Language and Culture of Bulgarians.] Moscow: Indrik.

Simek, Rudolf 2007 (1984). Dictionary of Northern Mythology. Cambridge: D. S. Brewer.

SSKJ 1986. Slovar slovenskega knjižnega jezika 3. Ne-Pren. [Definitive Dictionary of Standard Slovenian]. Ljubljana: SAZU - Državna založba Slovenije.

Stahl, Paul Henri 1987. Le départ des morts. Quelques exemples roumains et balkaniques. In: D. Fabre (ed.) Etudes Rurales (Le retour des morts), Vol. 105-106, pp. 215-241.

Tatar, Maria 1987. The Hard Facts of the Grimms' Fairy Tales. Princeton, New Jersey: Princeton University Press.

The Poetic Edda 1999. Transl. by C. Larrington. Oxford: Oxford University Press. 
Theogony $=$ Hesiod 2009. Theogony . Ed. by Martin L. West. Oxford: Clarendon Press.

Thompson, Stith 1997. Motif-index of folk-literature: a classification of narrative elements in folktales, ballads, myths, fables, mediaeval romances, exempla, fabliaux, jest-books, and local legends. Bloomington, Indianapolis: Indiana University Press.

Timm, Erika \& Beckmann, Gustav Adolf 2003. Frau Holle, Frau Percht und verwandte Gestalten. Stuttgart: S. Hirzel Verlag.

Tolley, Clive 2009. Shamanism in Norse Myth and Magic. Vol. II. Reference Materials. (FF Communications 297). Helsinki: Suomalainen Tiedeakatemia.

Toporov, Vladimir N. 2002. Predzgodovina književnosti pri Slovanih. Poskus rekonstrukcije. (Uvod v preučevanje zgodovine slovanskih književnosti). [Prehistory of Slavic Literature. An Attempt of a Reconstruction. (An Introduction to a Research of a History of Slavic Literatures).] Ljubljana: Department of Ethnology and Anthropology.

Tristia $=$ Ovid. Tristia . Transl. by A. S. Kline. http://www.poetryintranslation.com/PITBR/ Latin/OvidTristiaBkFive.htm\#_Toc34217360, last accessed on 30 July 2011.

Uther, Hans-Jörg 2004. The Types of International Folktales. A Classification and Bibliography, Based on the System of Antti Aarne and Stith Thompson. Editorial staff: Sabine Dinslage, Sigrid Fährmann, Christine Goldberg, Gudrun Schwibbe. 1: Animal Tales, Tales of Magic, Religious Tales, and Realistic Tales, with an Introduction. (FF Communications 284). Helsinki: Suomalainen Tiedeakatemia. Valencova, Marina M. 2001. "Vreteno". In: S. M. Tolstoj \& L. Radenković (eds.) Slovenska mitologija. Enciklopedijski rečnik. Belgrade: Zepter Book World.

Van Gennep, Arnold 1998. Le folklore français I-IV. Paris: Robert Laffont

Vaz da Silva, Francisco 2002. Metamorphosis: The Dynamics of Symbolism in European Fairy Tales. International Folkloristics 1. New York: Peter Lang.

Vaz da Silva, Francisco 2003. Iberian Seventh-Born Children, Werewolves, and the Dragon Slayer: A Case Study in the Comparative Interpretation of Symbolic Praxis and Fairytales. Folklore, Vol. 114, No. 3, pp. 335-353.

Vaz da Silva, Francisco 2008. Archeology of Intangible Heritage. International Folkloristics 4. New York: Peter Lang.

Vèlius, Norbertas (comp.) 2002. Lithuanian Mythological Tales. Vilnius: Vaga.

Vinogradova, Liudmila N. 1999. Notions of "Good" and "Bad" Death in the System of Slavic Beliefs. Etnolog, Vol. 9, Issue 1, pp. 45-50.

Vinogradova, Liudmila N. 2000. Narodnaia demonologiia $i$ mifo-ritual'naia tradiciia slavian. [Folk Demonology and Myth-Ritual Tradition of Slavs.] Moscow: Indrik.

Vukanović, Tatomir 1935. Verovanje u drugi svet kod Crnogoraca u Kosanici. [Beliefs in the Otherworld of Montenegrins in Kosanica.] Glasnik etnografskog muzeja, Vol. 10, pp. 127-128.

West, Martin L. 2007. Indo-European Poetry and Myth. Oxford: Oxford University Press. Wilkins, Eithne 1969. The Rose Garden Game. The Symbolic Background to the European Prayerbeads. London: Victor Gollancz.

Wright, Craig 2001. The Maze and the Warrior: Symbols in Architecture, Theology, and Music. London: Harvard University Press.

Zečević, Slobodan 1982. Kult mrtvih kod Srba. [The Cult of the Dead of Serbians.] Belgrade: "Vuk Karađić", Etnografski muzej. 


\title{
THE DISCURSIVE SUPPRESSION OF WOMEN: FEMALE EVILS AS THE VILLAINS OF THE MOTHERHOOD NARRATIVE
}

\author{
Leyla Önal
}

\begin{abstract}
This article focuses on the discursive construction and control of female sexuality and sexual activity, which simultaneously lead to the definition of women as inherently evil and to their suppression. This process is reinforced through a "motherhood narrative" inaugurated by a number of discourses, wherein female evils play the role of the villains, either as evil women or as anthropomorphised female beings that harm the mother or the unborn/newborn baby. The role of the "female evil", a universally occurring archetypal motif, is to steal, kill or harm the child or the mother during pregnancy, labour, or puerperium. This motif is taken into account particularly in the framework of discourses that can be termed as medico-religious. Case studies of female evils are given as examples in the article, with a focus on the motherhood narrative and medico-religious discourses. This focus provides an insight to the way in which female evils pertain to the suppression of women within a more general framework. Female evils appear as necessary constructs of the aforementioned discourses to be able to control female sexual activity and the motherhood related fears of women, especially through the internalisation of control and through shaping the relationship of women with other women.
\end{abstract}

Key words: Albast, Ancient Mesopotamia, birth, childbed fever, Lamaštu, Lamia, Lilith, medico-religious discourse, motherhood, sorcery, strigae, witchcraft.

\section{THE DISCURSIVE SUPPRESSION OF WOMEN: FEMALE EVILS AS THE VILLAINS OF THE MOTHERHOOD NARRATIVE}

The female body has been seen in various cultures as a site of contamination, causing impurity also for others, through socially unacceptable forms of contact. Therefore, the female body, as the site of abjection ${ }^{1}$, served as the basis of the symbolic constructs which associate women with specific forms of "evil". The abjection of the female body is most overtly manifest in the processes of menstruation - conceptualised as unclean in many cultures ${ }^{2}$ - and labour, as the essential processes of female reproduction. Paradoxically, female repro- 
duction, as the subject of numerous discourses from medicine to law and religion, incorporates both fear and fascination.

This article focuses on the construction of a "motherhood narrative" around this fear and fascination related to female reproduction. This narrative, as the subject of numerous discourses, is important in terms of illustrating how women's suppression takes place in a narrative which includes phenomena typically belonging to the "feminine realm" and how other women as symbolised in the form of "female evils" can serve as the agents for further facilitating this suppression. Among these discourses related to the motherhood narrative, the medico-religious ones are of particular interest since they associate female evils both with bodily and mental illnesses within the narrative. The female evils play a dual role in the narrative, both in terms of representing the repressed parts of female sexuality - as the fearful side of women - and also the fears of women related to motherhood.

The first part of the article provides an explanation of the concepts of motherhood narrative and female evils. The second part includes examples of the case studies of female evils and looks at their existing similarities in function in spite of their contextual specificities. The third part examines the ways in which the motherhood narrative is constructed through medico-religious discourses in a way to serve the suppression of women, with the help of the female evils. The final part deals with the suppression of women within a more general framework, through discourses which facilitate the differentiation not only between men and women, but also between women and other women.

\section{THE NARRATIVE AND THE VILLAINS}

Although the numerous discourses related to reproduction in general, and female reproduction in particular, can be to a large extent culture specific, they nevertheless serve to construct female sexuality and control female sexual activity; either in essentialist or in constructivist terms, or both. The control of female sexual activity and thus female reproduction is important as the means of securing the continuation of the bloodline in particular and society in general.

These discourses ascribe women with an exchange value ${ }^{3}$ concomitant with the motherhood narrative. The latter is necessary for the maintenance of the social order where the role of women in the division of labour within the public and private spheres is defined usually in terms of concepts related to motherhood. With the same token, motherhood is considered the proper role for women, and being a mother is presented as both a socially and individually desirable goal. This desire has to be fulfilled by women in a legitimate, and 
thus, permissible way. Therefore, motherhood $^{4}$, as used here, does not merely refer to being a mother but specifically to "motherhood in a legitimate form".

The "motherhood narrative" can be seen as a universal fiction which represents motherhood as an unequivocal goal for women. This narrative includes phenomena such as conception, infertility, menopause, pregnancy and pregnancy loss, the health of the mother and the baby in general, and childcare; phenomena which typically remained in the feminine realm. Thus, the motherhood narrative is used as an operational concept which includes all the aforementioned phenomena in the feminine realm, but excludes the unspeakable aspects of femininity which slightly correspond to "women as sexual agents ${ }^{5}$ " or the "dark side of the feminine" .

Within a context where female sexuality belongs to the realm of bodily impurity and discursive silence, the motherhood narrative comes to be associated only with pregnancy, labour and childcare through the conciliation of female sexual activity. Thus, motherhood becomes the sole - asexual - site of female activity, which, on the one hand represents the fulfilment of the female desire, and on the other hand defines this site as separate or even purified from female sexual activity. Thus, the motherhood narrative in this sense tells the story of female reproduction, but not of female sexuality.

The phenomena which typically belong to the "feminine realm" of the motherhood narrative, for the most part remained untouched by men. Once female sexuality remains under control and the motherhood narrative takes place within a framework of legitimacy, men do not play any major part in this narrative at all (Zingsem 2005: 283). Nevertheless, the feminine realm is not free from the mechanisms of construction and control, with one exception: within this realm, these mechanisms operate according to different dynamics.

The feminine realm is intriguing in this sense, since it seems like a site of action for women, but at the same time, it also serves for the activity of female evils. Therefore, the feminine realm of the motherhood narrative can act as a site of suppression for women, where the agents of the suppression are other women.

The motherhood narrative differentiates between mothers and other women in a way that legitimate mothers are valorised and put in a position not only as different from, but also as superior to other women. The position of legitimate mothers can also serve for loathing other women, as in the case of adulteresses (illegitimate mothers), murderous midwives, barren or childless women and bad mothers. These are "other" women who represent the dark side of the feminine and the fears of women related to motherhood. These two elements are symbolised in the form of female evils which play the role of the villain in the motherhood narrative and facilitate the suppression of women. 
This suppression operates through a twofold process: first, the birth related fears of women have to be replenished, and then, the dangers inherent in the narrative - like pregnancy loss or postnatal death - have to be exorcised and kept outside in order that the former start working as mechanisms for the internalisation of control.

The female evils constitute the exorcised elements of the narrative through playing the role of the villain. The villain of the motherhood narrative is necessarily a female evil, whose task is to steal, kill or harm the unborn/newborn baby or the mother during pregnancy, labour, or puerperium. Mothers and their unborn/newborn babies are threatened by a female evil, which can be any kind of harmful being incontrovertibly conceptualised as female.

The idea of the female evil works in two ways: either the perceived harmful supernatural and magical forces or beings are presented as female, or the actions of women can be associated with harmful magic and sorcery. Therefore, the female evil can be a woman embedded in a discourse which sees evil as an innate characteristic of women - the dark side of the feminine, or it can be an evil force or being, represented as female, or appearing in the form of a woman.

Within a discourse which defines women only in their relation to men - as daughters, wives and mothers - the female evil simply connotes "other" women, who escape this bind and thus, evade societal control mechanisms. These women are disruptive for the system since their role in society is defined as being illegitimate mothers and barren or childless women. Although the female evils can be mothers themselves, their status as mothers is always illegitimate. They are the antitheses of proper women, being condemned to be seen as evil and malevolent.

In short, the female evil is a harmful woman or an anthropomorphised female being, playing the role of the villain of the motherhood narrative instead of playing her proper role as an obedient woman. Female evils represent the repressed sexuality and fears of proper women, and facilitate the suppression of the latter by the attribution of an innate evil to women.

\section{WHERE ARE THE FEMALE EVILS?}

Female evils of the motherhood narrative can be found within a spatial and temporal variance. The first known examples which are going to be presented in the article appeared in ancient Sumer, Assyria and Babylonia. These in turn have been articulated into Rabbinic literature ${ }^{7}$ and found their way into various other settings. However, there are a number of additional examples that 
appear in significantly distant cultures. Due to the distance of the cultures, the possibility of cultural influence through migration ${ }^{8}$ (Hurwitz 2009: 46, 134, 223 ) is ruled out, an observation which can lead to the conclusion that the female evil is a universally occurring archetypal ${ }^{9}$ motif. The examples of this motif include Baba Yaga of the Russian and Slavic peoples, Hariti of the Buddhists of India, Kishimogin of Japan, Black Annis of English folklore and Langsuir of Malaysia among many others. All these examples from varying geographies represent the cultural transformations of the same archetypal motif, which is known as Lamaštu in Mesopotamia, Lamia, Empusa, Mormo and Gello in Greece and Rome, Strix, Striga or strigae and the witches of early modern Europe, and Albastı or Al-karısı in contemporary Anatolia.

These latter examples are chosen in a subjective manner to represent the variations of the motif within a limited geographical proximity, keeping the possibility of cultural interaction and historical reciprocity ${ }^{10}$ open. The examples illustrate a continuity within which the first example comes from Ancient Mesopotamia and the last from contemporary Anatolia. The middle examples are from Ancient Greece and Rome and early modern Europe, which, altogether, form a general picture of the female evil of the motherhood narrative. The final example is peculiar in the sense that it illustrates not only the existence of female evils even in the contemporary world, but also points out the traces of the medico-religious discourses that had been used for defining their role.

Although these female evils appear in a multiplicity of forms and pertain to their cultural specificities, they also have analogous traits and present functional contingencies. The given examples are seen as variations of the same archetypal motif, which represent both the transformation of the female evils on the one hand, and the preservation of the functional contingencies on the other. These examples constitute merely descriptive categories which should not be regarded as overall in-depth studies of the presented female evils.

Each example is unique in character and they point out that in spite of the spatial and temporal variances, the motherhood narrative is endowed with both fearsome and miraculous elements which open up a role for the female evils.

Lamaštu is the example from ancient Mesopotamia, and can also be found in Assyria, Sumer and Babylon. Although she was known as Lamaštu in Assyria, she probably originated from the Sumerian Dimme or Lamme. The concept of this deity spread also to Syria. The Hurrians probably introduced her to Anatolia (Leick 1998: 109). 
Lamaštu appeared in various cuneiform tablets which presented her in association with disease and difficulty in childbirth (George \& Finkel 2000: 252-253). Lamaštu was defined either as a demon, goddess or monster (Ann \& Imel 1993: 336), and in all of these forms she was identified as a female being. In Sumer, she was a lion-headed goddess who coveted humans and their children. She was also described as having donkey's teeth, bare breasts and a hairy body, blood-stained hands with long fingers and nails, and the clawed, talon-like feet of a bird (Hurwitz 2009: 43; Leick 1998: 110).

In Assyria Lamaštu was a demon-goddess who taunted the sick and infected children with the plague and killed them. As Charles Russell Coulter and Patricia Turner (2000: 285) point out, she also appeared as a winged animal, or was depicted as a woman with wild hair and bare breasts.

The traits ascribed to Lamaštu included slaying infants and unborn babies, causing harm to mothers in general and expectant mothers in particular, sucking men's blood and eating their flesh and bringing disease and death. She was generally held responsible for miscarriage and cot-death and represented the danger of infant and child mortality (Leick 1998: 110). She taunted the sick and carried the plague around by means of feeding poisonous milk to babies from her breasts and by using her talons to tear the flesh of humans. "Bring me your children to suckle, I shall be their nurse" was her call (Leick 1998: 110). She could slide in and out of houses at will, terrifying the inhabitants. She was known to have a violent temper, and when in rage, she could slay domestic animals with her bare hands.

To protect herself and the child from Lamaštu, the expectant mother had to wear a protective amulet made of bronze, or metal. Another method of protection was to keep stone plaques with inscribed incantations in and around the house. Gwendolyn Leick (1998: 110) notes that “...many charms and masks have been excavated in the ancient towns which used to hang by doorways in the hope of keeping her at bay."

Lamia is the Greek equivalent of Lamaštu (Hurwitz 2009: 43). The demonic Lamia, whose name means 'devourer' (March 1999: 229), appeared in classical Greece and Rome. Lamia was the personification of the land of Libya, and she also was the land's queen. She was a very beautiful woman and attracted the attention of Zeus ${ }^{11}$, to whom she bore children. When Zeus's jealous wife Hera ${ }^{12}$ found out the affair, she killed Lamia's children every time Lamia gave birth. The loss of her children drove Lamia insane, and she retreated to a solitary cave (Grimal 1990: 236). She became jealous of mothers who were more fortunate than herself. In despair and seeking vengeance, she started to steal and kill the children of other women (March 2001: 451). Her cruelty - or grief - 
started to reflect upon her and she became monstrous with distorted features. She was depicted as a creature with the body of a snake and the head of a beautiful woman (Hurwitz 2009: 43). Siegmund Hurwitz notes that even today there is a belief in Greece that if a young boy, especially a handsome one, whistles on the beach at midday or midnight, the Lamia of the sea rises and wants to take him as her husband. If the boy refuses, she kills him (2009: 43).

Later, the Lamia figure of classical Greece and Rome took the plural form lamiae, referring to beautiful ghastly women. They attracted men, used up their energy, drank their blood and ate their flesh. As Robert Bell (1991: 312) notes they were the equivalents of the contemporary conception of vampires. Another example of lamiae comes from the stories of Europe in the Middle Ages. Hans Peter Broedel (2003: 104) refers to these stories which mentioned beings called lamiae, appearing as women who slipped into houses, killed children and conducted other gruesome deeds. These creatures had the faces of people but their bodies were of beasts.

Other accounts of the presence of lamiae in the Middle Ages include Johannes de Janua's 13th century work Catholicon, in which Janua explains the etymology of lamiae (Broedel 2003: 104). The name lamiae had conventionally been delivered from laniāre meaning 'to rend'. The work also mentioned about lamiae that they had the habit of tearing children into bits. It has also been added that old women snuck into houses pretending lamiae were there, killed infants, tore them into pieces and resurrected the bodies.

The lamiae of the Middle Ages were described as demons or spirits. Therefore, even if they could not consume children's flesh in their incorporeal form, they occasionally killed children to punish their parents. Female spirits who attached themselves to little children in order to suck their blood were also called lamiae (Grimal 1996: 296). Lamiae entered houses at night and oppressed sleepers, moved infants from place to place or molested them, drank human blood and caused serious illness. Other names and forms of the Greek Lamia were Empusa, Mormolyceia (known as Mormo) and Gelo (Bell 1991: 312; Grimal 1996: 296).

Empusa was a female Graeco-Roman spirit which haunted the night, a bogeywoman, with one donkey's foot and the other made of brass (Grant \& Hazel 1993: 20). She was thought to assume various shapes and sometimes vanish altogether (Luck 1999: 130). She was one of Hecate's ${ }^{13}$ companions and Hecate used the empusae to frighten foreign travellers. Empusa was believed to be able to assume various shapes and appeared particularly to women and children (Grimal 1990: 136). At the same time she was known to take the form of a beautiful young woman to lure men and suck their blood dry until they were 
dead. To escape from her, one had to insult her loudly, which would make her flee shrieking (Grimal 1996: 146) or "squeaking like the devil" (Luck 1999: 130). She was a night-witch figure, who had the habit to "...feed on young and beautiful bodies, because their blood [was] pure and strong" (Gordon 1999: 217). Hurwitz (2009: 44) noted about the Empusa that, like Lamia, she lives in the fairy tales and folklore of modern Greece.

Mormo was a Greek demoness whose name means 'frightful' (March 1999: 261). She was believed to bite little children, especially the naughty ones and make them lame. Mormo was a hideous she-monster who attacked little children and used nursery-bogeys to frighten them into good behaviour (March 2001: 514). She even killed and ate her own offspring (Hurwitz 2009: 44). Like Empusa, Mormo was a shape-shifter, who could take up the form of a young woman to attract men and consume their blood and flesh.

Gelo of Ancient Greece appeared as Gelou in Hebrew, and as Gallu or Gello in Babylonian, Sumerian and Semitic languages (Coulter \& Turner 2000: 185, 189) and as Gello, Gylo or Gyllou in Graeco-Byzantine mythology (Hurwitz 2009: 41). Gelo was an ogre living on the island of Lesbos, being the tormented soul of a maiden who had died young and kept returning to earth to steal children (Grimal 1996: 170).

Strix ${ }^{14}$ was a Graeco-Roman child-stealing, bloodsucking enchantress (Hurwitz 2009: 44-45) which also originated from Lamia. She later took the form of the strigae of the Middle Ages which were malevolent bird-like creatures (Broedel 2003: 104). Hurwitz (2009: 46) mentions that Striga may have been derived from Hystera, the demon who spells danger for the mother's womb ${ }^{15}$. Hurwitz (2009: 44) also states that this figure lives on in contemporary Greek popular culture together with Neo-Greek folk tales and legends.

Strigae of the Middle Ages were dangerous birds that flew by night searching for infants to nourish themselves by sucking their blood and devouring the flesh. Hurwitz (2009: 44) states that strigae, in folk tradition, are enchantresses who "...fly at night in the guise of birds to the cradles of children and suck their blood". According to Grimal (1996: 427) strigae, in popular belief, were winged female demons with talons like those of birds of prey who fed on the blood and entrails of little children.

Francis King (1987: 20) notes about the strigae that during the early periods of Christianity, human servants of Satan were believed to be strigae and have powers very similar to those attributed to the witches ${ }^{\mathbf{1 6}}$. They were birds of prey with talons capable of tearing the flesh and possessed breasts of women which were filled with poisonous milk like the Assyrian Lamaštu. They offered 
milk to babies left lying unprotected in their cradles. Thus, they were often seen as the cause of postnatal death. Moreover, they sometimes flew to sleeping men and drained their blood and energy while having intercourse with them.

To point out the conventionality of the belief in strigae, Broedel (2003: 168) gives the example of the 6th century Pactus Legis Salicae. The Pactus ordered that a striga - the singular form of strigae - which was proven to have eaten a man was liable to a fine of 8000 denarii. It has also been stated by King (1987: 21) and P. G. Maxwell-Stuart (2004: 221/illustr. 4) that strigae were often identified with the screech-owl and commonly denoted a witch that could change her shape and fly. King (1987: 21) adds that “...it was probably for this reason that as late as the 16th century a common English term for a man who was wasting away as the result, so it was believed, of witchcraft, was referred to as "owl blasted"."

The witch, as a generic category for women with ill-repute who conduct evil deeds, is closely connected to the lamiae and strigae. The witch is a common figure in folklore and fairy tales, usually depicted as an ugly and elderly woman. During the Middle Ages, many women were accused of being witches and were held responsible for threatening expectant mothers and newborn children besides other malevolent acts. According to Broedel (2003: 3) 15th century Europe was the landmark of the witches' chronicle and thousands of women were accused of being witches, tortured and sentenced to death.

Broedel states that "...prior to the 15 th century, people spoke in terms of heretics, of maleficium, of monstrous female spirits - the lamiae and strigae, but not of a single composite category of "witch"." (Broedel 2003: 3) However, by the midst of the 16th century, scholars generally agreed upon the definitions of "witch" and "witchcraft", definitions which drew upon, but were clearly distinguished from older categories. Witchcraft was described as a phenomenon which was explicitly gendered and highly sexual in nature (Broedel 2003: 20). The phenomenon of witchcraft appeared in a setting where, according to Marianne Hester, gender relations were an integral part of the Christian political ideology, and there was a "...sexual double standard with female sexuality presented as inferior to that of men..." (Hester 1996: 292). Women were seen as inferior to men since they were "...perceived as more likely to be sexually deviant than men because women were by definition (like Eve in the Garden of Eden) sexually deviant" (Hester 1996: 296; Roper 1994: 18). This discourse presented women as inherently evil and was used for blaming them for various ills. 
Since women were by definition more sexually deviant, the practice of witchcraft was seen as resulting from the insatiable sexual desire of women (Hester 1996: 292). The libidinous witches cast spells on men in order to make them unable to engage in benign sexual intercourse with their wives. Thus, the victims became the subjects of the witches' sexual desires. Gareth Roberts, in a similar fashion like that of Hester, argues about the sexual nature of witches that "a metaphoric extension of the idea that witchcraft is seductive, pleasurable and unmanning is the use of this nexus of ideas for purposes of Protestant propaganda in the sixteenth- and seventeenth-century England." (Roberts 1996: 201)

Even though every woman could be accused of being a witch at the time, the most susceptible women were the midwives according to Broedel (2003: 7). The midwives were commonly accused of being witches because of their highly skilled knowledge in herbalism, medicine and other practices particularly related to reproduction and the female body such as contraception and their role in assisting the labour process. All these tasks being performed by midwives denoted the loosening of the power over female sexuality and put the midwives with their inexplicable powers in a suspicious position. Thus, the most formidable kind of witch was the midwife-one, who specialised in killing and eating un-baptised children. Broedel states that the midwife-witches were the worst of all their kind "...for they kill[ed] infants both in the womb and at birth, and [were] even in the habit of stealing, vampire-like, into homes to drink the blood of children." (Broedel 2003: 27) Witches also had the ability to fly (Broedel 2003: 183) and change shape in some accounts, which can also be interpreted as an indication of the homology between witches and the night-flying strigae.

However, the witch-trials in Germany during the 17th century indicated a shift in the attention concerning the deeds and behaviour of witches. According to Roper, these trials were particularly focused on "relations between mothers, those occupying maternal roles and children" and they typically included “...accusations brought by mothers, soon after giving birth, against women intimately concerned with the care of the child..." (Roper 1994: 202) Therefore, Roper identifies the lying-in-maid as another category of women frequently accused of being witches, since they were concerned with the care of the child right after birth. Although the midwife-witch represents the fears of men about loosening their control over the labour process, the lying-in-maid represents the fears of the mother, and a shift of attention from sexuality to motherhood.

This focus on motherhood is illustrated by the witch-trials, where the activities of the witches were mentioned as including harming the baby or the mother by pressing, or pushing them down during labour. This activity was referred to in German as drücken, a verb denoting the use of witchcraft in at 
least three different contexts: “...to describe the way the Devil forces one woman to do evil, the smothering of an infant, and a mysterious kind of oppression felt by the woman who has just given birth." (Roper 1997: 210)

Although during the period men were also accused of being witches, the significant majority of witches were women. As stated by Marianne Hester (1996: 291), with reference to Christina Larner, "witch hunting is woman-hunting or at least the hunting of women who do not fulfil the male view of how women ought to conduct themselves."

Lilith, as another example of the motif, originated from Ancient Mesopotamia and found her way into Jewish mystical traditions. Her name also appeared in various cultures, including the Sumerian, Babylonian, Assyrian, Jewish and Arabic (Hurwitz 2009: 32). It has been stated by Coulter and Turner (2000: 285) that Lamia as a child-slaying demon can be seen as the forerunner of Lilith of the early Hebrews. Lilith is closely associated with the lamiae and strigae who brought death to newborn babies and fed on human blood and flesh (Calmet 1993: 67).

The name Lilith first appeared in the Sumerian Epic of Gilgamesh where she was referred to as a creature that flew to desolate places, and haunted the deserts after her shelter was destroyed by the hero Gilgamesh (Patai 1968: 27). Later, Lilith and incantations against her appeared on the Nippur Bowls ${ }^{17}$ of Babylonia. The texts on these incantation bowls about Lilith indicated that she attached herself to sleeping humans and acquired rights of cohabitation through this attachment as a result of which she generated demonic offspring (Lesses 2004: 357-358; Levi 1995: 23).

In the post-Biblical period, Lilith appeared as the first wife of Adam, and they both were created from dust, earth or clay (Black Koltuv 1986: 22; Levi 1995: 21; Zingsem 2005: 35). Adam and Lilith could not be happy together since they had a dispute about the manner of their intercourse. Lilith told Adam "I will not lie beneath you"18 (Cantor 1998: 19), and she pronounced the ineffable name of God (Yhwh $\left.{ }^{19}\right)$, became a she-devil and acquired wings ${ }^{20}$. She flew away to the Red Sea, the place which was regarded as the realm of demons and other mischievous creatures (Levi 1995: 22) ${ }^{21}$. Adam felt lonely when Lilith left and asked Yhwh to bring her back. Yhwh sent three angels, Snwy, Snsnwy and Smnglf ${ }^{22}$ (Scholem 1974: 357) to persuade Lilith. After listening to their message, Lilith refused to return, and the angels cursed her because of her disobedient reply. The punishment brought upon her was the death of one hundred of her offspring each day. Moreover, the angels made Lilith swear an oath saying that wherever she saw the angels' name on an amulet or image, she would do no harm to the baby. 
It was a common practice to protect women from Lilith during childbirth by putting amulets over the bed, on the door of the room and the four walls of the room. According to Gershom Scholem, amulets, portraying not only the names but also the forms of the three angels, Snwy, Snsnwy and Smnglf, were printed even as late as in the 18th century (1974: 358). Likewise, Scholem points out that from the 16th century onwards, it has been a common belief that if a child was laughing while asleep or alone, Lilith was playing with him or her (Scholem 1974: 358). Dom Augustine Calmet (1993: 67) also notes that the belief in Lilith was apparent in the practice of writing "Adam, Eve. Be gone from hence lilith", in the corners of the room where a woman just delivered her baby.

The Hebrew name Lilith, which appears in the Bible; in Isaiah 34:14 of the Old Testament (Black Koltuv 1986: 11), is translated as the 'screech-owl' or 'night monster' (Ann \& Imel 1993: 336). Although the stories about Lilith are multiple, her role in the multiplicity of these stories is enmeshed in the common themes of killing unborn/newborn babies and infants, flying at night, sneaking into houses and disturbing humans while they sleep, taking the shape of a beautiful woman and having intercourse with men, then sucking their blood and eating their flesh. Lilith also managed to prevent the birth of children by causing barrenness, miscarriage, or complications during childbirth.

Lilith was sometimes used in a multiple form, referring to a group of succubi. Raphael Patai (1968: 212) states that succubi were jealous of the human mates of the people to whom they attached themselves. Because of their jealousy, the succubi hated the children born of ordinary human wedlock and tried to harm them. It is not clear why Lilith was bound to harm babies even before she had been cursed by the angels. Her reaction can nevertheless be regarded as an upheaval against her punishment or as an act of jealousy. Probably, she sucked the blood of human infants, plagued and strangled them for avenging the death of her own offspring. According to Raphael Patai (1968: 229), Lilith remained in the imagery of the Jewish tradition as a child killer up until the 19 th century, and continued her existence in folklore later on. Black Koltuv (1986: 11) states that although there is no further explicit mention of her by name except in Isaiah 34:14 as quoted above, “...these images exist in the modern psyche" ${ }^{23}$. It is still a custom - the roots of which may have been long forgotten - that the sleeping child should be tapped three times on the nose to avoid dangers from Lilith when she is caught playing with the child.

Albastı, or Al-kartsi probably had its roots in the animistic religions of the peoples of contemporary Anatolia who migrated there from various geographical locations. Together with contemporary Anatolia, the belief in Albastı was common among the Turkic people, and the name appeared as Albastı or Al- 
karıst in the Middle and West Asia, as Albız in the Ottoman writings, as Albis among the Uranha-Tuba Turks, as Almıs among the Altai Turks, and as Abası among the Yakut Turks (Çay 1983: 53). Albastı was also adopted by the Armenian, Georgian and Caucasian cultures (Çobanoğlu 2003: 124-125); likewise, Orhan Acıpayamlı (1974: 11) mentions that evidence can be found in various historical documents from Ancient Egypt, Ancient Greece and Sumer that there have been beings corresponding to the Al-spirit.

The inhabitants of Anatolia may have borrowed Albastı from Egypt, Hittite and Sumer (Eyuboğlu 1998: 122), cultures in which the belief in spirits attacking women or babies, during and after childbirth, was common. Since the folk tradition of Anatolia has always been reflected upon the amalgamation of the belief systems of the various peoples who ruled parts of Anatolia throughout the ages, the descendants of these peoples contributed to contemporary Anatolia's multicultural population, and the traces of their beliefs can still be found across the region in a multiplicity of forms.

The belief that a puerperal woman and her newborn baby could be harmed by beings, which can be referred to as spirits or jinn ${ }^{24}$, is apparent in Anatolian folk tradition. This condition of being harmed, or the being which causes the harm is called Albastı or Al-karısı, which are the most common names among various others. Albast is a female being, unambiguously indicated by her other common name Al-karıst, in which the second part means "woman" or "wife" (Doğan 1981: 529). Al-karısı simply means "red hag"'25, where kart is the vulgar form of "wife, old woman, hag" (Redhouse 2004: 536) ${ }^{26}$.

Albast in some occasions is described as a spirit, and can also be a jinn, fairy or demon which appears in many disguises, from a giant to a spider or a witch-woman. This witch-woman can be a tall blonde, or a woman with scattered black hair. In her accounts, she can have both a zoomorphic appearance and also a bestial one, wearing a red shirt. It is also believed that Albastı can alter her shape into various forms of a human-animal creature. Despite of all the possibilities, Albastı most often appears as a witch-woman (Acıpayamlı 1974: 75-76).

Regardless of the form that she takes, Albastı attacks women and children in order to feed herself or her own offspring. For this purpose, she tears off the lungs of her victims and suffocates them. The belief in Albastı can take two major forms: Albastı is either used as the name of a being, or as the outcome of the encounter with that particular being. This indicates that the two beliefs exist in a conjoined form, and that Albast is both a being and the name of an illness. Thus, it can be said that Albastı, which had once been a formless spiritual force, transformed into an illness and then turned into a being as the personification of that illness in a female form (Actpayamlı 1974: 119). 
In correspondence with the being, the Turkish idiom al basmak refers to the belief in folk tradition according to which the evil spirit al treads on the puerperal woman. When the $a l$-spirit strikes, the woman turns red, which in fact is a condition caused by puerperal fever (Püsküllüoğlu 2003: 87). In medical terms, al refers to erysipelas, puerperal fever (İz 1992: 17), and also to childbed fever, whereas the verb form al-basmak means 'to get puerperal fever' (Redhouse 2004: 31), experienced by puerperal women due to the lack of proper sanitary conditions. The state of reddening and suffocation, which are believed to be caused by Albastı, are actually the results of common medical complications. The puerperal mother or the newborn baby may turn red due to fever or lung inefficiency. The fever known as puerperal or childbed fever is caused by an infection within the uterus, causing a febrile state resulting from the infection of the endometrium and septiciemia following delivery (Gennaro 1979: 1130). If the infection involves the bloodstream, it can develop into puerperal sepsis, which is a serious form of blood poisoning, as a result of which the whole body may enter into an inflammatory state to fight the infection, with symptoms of redness and swelling.

Just like the mother, the baby would also turn red as a result of the attack of Albastr. The medical name given to this condition is postnatal asphyxia and atelectasis, or, in other words, the respiratory distress of the newborn (Gennaro 1979: 1086). When struck by $A l$ the mother or the baby would feel as if being under a heavy load, unable to breathe and talk; a symptom which is common to both medical conditions.

Albastı strikes only puerperal women, and newborn babies who are younger than 40 days. This belief also has a medical explanation, since 42 days or six weeks is the period required for the uterus to return to its normal size after birth (Stedman 1995: 1464; Martin 1994: 549). After this period, the involution of the uterus is complete.

Paralleling the various appearances of Albastı, the measures taken for protection may vary across regions, however, every variant includes the common element of protecting the mother and the baby by way of the colour red. The most common practice is to tie a red scarf around the head of the mother and to cover the baby with a similarly coloured cloth for forty days. Other practices include using red ornaments on pillows, a red blanket as a cover, or wrapping a red ribbon around the head. To protect the puerperal woman from Albast and possible troubles, ropes are stretched out across the room over the woman's head, and onions, mirrors and the Quran are hung on these ropes (Gökbel 1998: 94). In case of an encounter with Albastı, an immediate warning should be made, and a nearby person should hold the mother or the baby tight when being attacked by Albastr. To make them come to their senses and fight against 
Albastı, the mother or the baby should be shocked by a sudden action or noise - if they do not struggle, Albastı takes over and brings them to the point of suffocation (Gökbel 1998: 94; Çay 1983: 54). In some areas a ritual which includes the singing of holy songs is performed to prevent suffocation; a lamb's lung may be offered to Albastı to take instead of the lung of the mother or the baby (Çay 1983: 54). Moreover, the guests are not allowed to hold a newborn baby, and the same ban is set for menstruating women in case the infant is less than forty days old. The visitors should be given a red drink called lohusa şerbeti (Boratav 1973: 187; Çobanoğlu 2003: 125) which is a red herbal potion made by boiling various herbs in sugary water.

Iron $^{27}$ is the protective element against Albastı, and it should be placed in the room of the mother and the baby. Moreover, making noises with iron or other tools made of metal make Albastı flee, since she is known to be afraid of the noise of iron or metal, as well as the material itself. Another belief is that Albast hides and dwells in barns, haylofts, and desolate places, ruins, in the proximity of water sources, rocks and fountains. These places should be approached only after certain protective words or phrases have been uttered.

It is also a common practice in some parts of contemporary Anatolia that experienced older women or midwives assist the mother and the baby during labour and puerperium and take care of their well-being. Midwives are usually not medical specialists but elderly women whose knowledge proceeds from experience in matters of childbirth in particular and female sexuality in general; as a rule, they have a number of children themselves. Sometimes they prepare special herbal medicines known as kocakart ilact (Redhouse 2004: 536), translated as 'folk remedy', 'hag's medicine' or 'witch's brew'; the know-how about the ingredients of which had traditionally been passed on to generations of women.

\section{MEDICO-RELIGIOUS DISCOURSES AND THE REPRODUCTIVE BODY: ALL WOMEN ARE SORCERESSES}

The given examples of female evils illustrate certain commonalities in crosscultural and cross-historical perspectives, presenting recurrent themes around which the concept of the female evil circles in relation to the motherhood narrative. Although some examples simultaneously carry out the double function of representing devious female sexuality and the fears inherent in the motherhood narrative, eventually, the former function tends to lessen and the focus becomes reduced to the role in harming the baby or the mother, especially in the cases of the witches and Albast. 
Besides being malevolent creatures and harming the mothers and babies, female evils are associated with sorcery and witchcraft, and have the ability to appear in many forms, transform themselves or to change shape. Catharina Raudvere (1996: 47) notes that special attention can be paid to female shapeshifters because "by contrast to many of the male characters with the same abilities, the women act almost exclusively out of greed, envy, depravity, corruption and unrequited love." This difference can be explained with reference to Frymer-Kensky who states that the myths of female revenge may have had "...less to do with actual female behaviour than with the projection of male feelings about the woman (mother)..." (1992: 204). These feelings combine both fear and fascination as noted in the beginning of the article.

The fears are manifested in a number of discourses related to female reproduction which cannot be understood separately - Holly Tucker presents the "...basic observation that conception and childbirth are at the core of the human experience; procreation is never "just" a biological phenomenon. The reproductive body is shared in virtually infinite ways by diverse cultural discourses that are always in dialogue with one another." (Tucker 2003: 15) Therefore, the suppression of women goes beyond the control of the female sexual activity and female reproduction, and disseminates through discursive practices as parts of “...the larger pattern of dominance-submission, which includes political, economic, and social, as well as theological dimensions." (Osiek 1985: 103)

Among all these numerous discourses, the medical and religious ones are particularly important in terms of talking about the motherhood narrative and the role of female evils. The medical discourse, in the sense we understand it today, constructs and controls the corporeality of the body in general and the female body in particular. The religious discourse works together with the former to extend the processes of construction and control to the psyche. They mutually rationalise each other and exist in a co-dependent manner. Together, in a form that can be referred to as medico-religious, these discourses cover both the mundane and the sacred elements of existence, where the body and the psyche are perceived in a conjoined form.

The medico-religious discourses brought protection from female evils into focus, through the use of rituals and incantations. These included protective measures against female evils, since the latter were seen among the major causes of complications such as miscarriage, postnatal death, childbed fever and various other ill-nesses.

The medico-religious discourse, wherein these female evils played their particular roles, can provide a better insight in order to understand the function of the given discourse in relation to a more general framework. The no- 
tion of medico-religious discourse can be best exemplified by looking at Ancient Mesopotamia, where medical and religious discourses were not quite separate. Within this context, the internal mechanisms of the body could only be explained with reference to outside forces such as various supernatural beings. Illness was perceived as an intrusion coming from outside and entering the body in some fashion, an understanding which intertwined the fields of medicine and religion. The people of Ancient Mesopotamia believed that various beings, such as demons and evil spirits, could be found everywhere and they could affect human life. These beings in general and female evils in particular, were seen as the causes of disease, illness and death. In some cases, they operated as personifications of certain disease ${ }^{28}$.

There are numerous medical texts ${ }^{29}$ from Ancient Mesopotamia that brought into light the ways of conceptualising illnesses, containing various prescriptions for certain diseases. JoAnn Scurlock (2006: 19) presents 352 "prescriptions" from Ancient Mesopotamia that had been used for treating physical, mental and spiritual symptoms, apparently associated with harmful "ghost" activity. The prescriptions included offerings, libations, figurines, ritual burial and dispatch, encirclement, amulets, fumigants, bandages, salves, potions, washes and suppositories among various others.

In Ancient Mesopotamia, there were two kinds of causes of illnesses, both of which could be associated with the activity of harmful beings. The first cause of illness or any kind of trouble was the punishment sent by higher forces, i.e. the deities, as a result of the offences committed by the person. These offences covered a wide range of acts, from disrupting the social order, to willingly or unwillingly breaking the taboos (Biggs 2005: 3). Another possible and more common source of physical or mental problems was sorcery. There were incantations which mentioned outsiders, specifically foreign women, as the instigators of sorcery. A variety of demons and other beings which usually had some partial human characteristics were mentioned in the aforementioned medical texts, on the basis of their relation to sorcery. The texts mentioned that the victims of these beings have been "seized" or "stroked" and that the beings caused the illness and death of their victims. Scurlock points out that these illnesses or harmful activities involved a number of medical symptoms which are related to women and children, such as "...barrenness, excessive vaginal discharges, difficulty in giving birth, puerperal fever and the like, or infantile afflictions, or jaundice, gall bladder, urinary tract problems..." (Scurlock 2006: 19) among various other symptoms.

Although the causes of illnesses were seen as supernatural, bodily illnesses have been diagnosed and treated on the basis of practical know-how. In Ancient Mesopotamia, medicine grew out of a folk tradition which can be referred 
to as herbal medicine in today's terms. This tradition included the use of plants and plant products, minerals, animals and their products as the basic ingredients of medications. Herbal medicine was practiced by both men and women. However, women possessed particular knowledge which remained largely unknown to men, primarily concerning the "invisible" or "unseen" - thus incomprehensible - parts of the female body and female sexuality. This knowledge had been passed on to generations of women in an oral form.

Robert Biggs (2005: 1) states that "female problems" related to pregnancy and childbirth had often been addressed in medical texts of Ancient Mesopotamia. He also underlines that the illnesses of babies and children were detailed in the chapters of the omen collection whereas the same diseases and illnesses were not mentioned at all in the medical texts (Biggs 2005: 9). This final statement can be seen as an indication that female evils were seen among the causes of illnesses and death of babies and children.

Labour was considered largely as a "female problem". Biggs (2005: 9) notes that in spite of the numerous prescriptions for physicians to treat a woman with complications after childbirth, there was no indication in these texts that physicians assisted in the delivery. Instead, assistance was provided by a midwife called šabsūtu who was probably aided by a female relative. Although these texts were predominantly medical, they frequently combined medical and magical treatment ${ }^{30}$, both of which were provided by men (Biggs 2005: 1). While the role of male practitioners of medicine and magic was clear, the role of the midwives or šabsūtu assisting the labour process remained quite vague.

Other examples of the medico-religious discourse of Mesopotamia included inscriptions on numerous incantation bowls and texts of Rabbinic literature, featuring the names and depictions of female evils and identifying the protective elements against them. Rebecca Lesses has examined the publications of 154 incantation bowls and notes that almost one half of these incantations mentioned Lilith or liliths at least once (2004: 354). About one third mentioned other female evil spirits and approximately ten percent referred to evil human women. In addition to these, the formulae on several bowls specified groups of women of some sort, particularly family members, as enemies who have cursed people (Lesses 2004: 355). In addition, having studied the Babylonian Talmud ${ }^{\mathbf{3 1}}$, which represented the major religious discourse of early monotheism in Ancient Mesopotamia, Lesses mentions that the Babylonian Talmud, in the legal discussion about sorcery, states that "most women are sorceresses" (2004: 343). She also points out that many other texts of Rabbinic literature, including the Torah $^{32}$ as a fundamental text, explicitly referred to women as sorceresses and sorcery was conceptualised as a feminine practice. This was accepted as a general fact about women and constituted the basis of the discourse that most 
women "...naturally, in the ordinary way of the world, are sorceresses" (Lesses 2004: 351). It has also been stated by Lesses (2004: 354) that the incantation bowls and Rabbinic literature had a lot in common with the beliefs concerning sorcery, although the incantation bowls, unlike the texts of Rabbinic literature, did not contain explicit statements about women's relation to sorcery, they nevertheless provided a gendered view about sorcery. Lesses notes that many incantations and amulets, belonging to both to the pre-monotheistic and monotheistic periods of the area, named the client of the incantation or the practitioner by his or her mother's name, instead of the father's name. This can be seen as an indication of the association of sorcery with women "at the ideological level" (Lesses 2004: 363).

The examples from the medico-religious discourses of the Graeco-Roman world illustrate a similar view about women as that of the rabbis. Lesses, having excessively examined the works of the writers of antiquity and late antiquity, states that these examples also depicted women as sorceresses. She presented the examples of Circe in the Odyssey, Medea in Euripedes and Seneca, Dido in Virgil's Aeneid, Erictho in Lucan's Pharsalia, and several witches in The Golden Ass by Apuleius. Lesses concluded that the association of women with sorcery in the Graeco-Roman world was an ideological act, which practically served as a means of control. Seeing women as sorceresses validated the exclusion of women from normal means of power. Furthermore, the accusation of women with the practice of sorcery provided a "stick with which women could be beaten". Since the mechanisms of sorcery were inexplicable and the practice of sorcery was a secretive act, the accusation of being a sorceress was almost impossible to refute (Lesses 2004: 366). This point is strengthened by Daniel Ogden's argument - in relation to the curse tablets ${ }^{33}$ of Ancient Greece and Rome - that women were often present even in tablets that appear to address disputes entirely between men, and that "...individuals in the tablets are often identified not by their father's name (patronymic), as was usual and proper in the ancient world, but by their mother's name (matronymic)" (Ogden 1999: 61), a form of addressing that may have been borrowed from Early Egyptian and Babylonian spells.

However, there was a major difference between the incantation bowls of Ancient Mesopotamia and the Graeco-Roman curse tablets, and the Rabbinic literature. The bowls and tablets were made for both men and women, mainly for protection against female evils or for lifting the curse of the latter. They reflected the fears of both men and women concerning the well-being of the family in general, and the health of their children in particular. At the same time, they also presented the primary concerns and needs of women in life: health, pregnancy, childbirth, children's health, sexual anxieties and the fear 
of demonic attack (Lesses 2004: 367; Hurwitz 2009: 113). While women were more concerned about issues related to the "feminine realm" men had different concerns in relation to female evils. Men were particularly concerned about sexual protection ${ }^{34}$ from the latter.

Conversely, Rabbinic literature was produced by a certain group of men, including the rabbis or other scholars and intellectuals. They produced texts primarily for each other or for other men. Rabbinic literature expressed male anxieties and fears which were particularly sexual in nature. Rabbis who led a secluded life were less concerned about the issues of daily life and more focused on power relations and the maintenance of their dominant position in society. Men, as rabbis, were the legitimate holders of supernatural powers, while women, as sorceresses, had illegitimate claims towards similar powers. As a result, women with supernatural powers or with powers of sorcery were regarded as threatening for rabbis' position. Rabbis did not hold an unchallengeable power in Ancient Babylonia (Lesses 2004: 368) and feared that women with the power of sorcery could contest them.

The infamous position of women as sorceresses was a part of the overall Rabbinic project that defined gender and labelled women as the source of evil deeds. This understanding of women as inherently evil is not any different from the case of the witches of early modern Europe, where women, like Eve, represented temptation and the fall. Such labelling served to rationalise the suppression of women in society which, within the Rabbinic project, included discarding women from the public realm and the crumbling of their ability to claim knowledge.

The women who were involved in medico-religious practices (e.g. midwives) came to be placed in a suspicious position since the phenomena these women were dealing with, and also their practices were "invisible" and "unseen" - and could thus evade male control. Due to their suspicious position, these women were accused of being sorceresses or witches, and became the female evils of the motherhood narrative.

\section{WOMEN AS “OTHERS”: THE DISCURSIVE SUPPRESSION OF WOMEN}

As it can be observed from the given examples, there is an inherent bias to associate only female evils with the motherhood narrative. The phenomena within the "feminine realm" of the narrative remained out of men's concern but not of control - even at the symbolic level. Hurwitz notes that the attitude of "...man towards the feminine is, at bottom, nothing more nor less than an 
expression of his deep-seated fears and his uncertainty of womankind. At the same time, behind these fears must also lie a certain fascination... it is both fear and fascination, which, with the utmost difficulty, fashion the man's debate with the feminine." (Hurwitz 2009: 184, 197)

Therefore, we can see that this debate with the feminine is centred on discourses which represent women as "radically other" (Frymer-Kensky 1992: 31 ) in comparison to men. For example, women were seen by the Greeks as inherently so different from men that they "...spoke of a genes gynaikon, a "race of women", as if women were an entirely different species of men" (FrymerKensky 1992: 203). A number of examples of female evils are born out of this context, which also influenced later discourses.

This worldview is not specific to Ancient Greece but represents the number of contexts from which the examples of the female evil are drawn. The GraecoRoman images of Father Zeus/Jupiter ${ }^{\mathbf{3 5}}$ which have been influenced by the imagery of Ancient Mesopotamia have in turn governed the shaping of the modern/Western psyche ${ }^{36}$. William Phipps (1989: 1) presents the further observation that "those sharing the Judeo-Christian heritage have generally assumed that the gender of the deity is masculine." This line of thought, which is also in line with the Muslim, tends to see the deity/Father/Creator/Lord/God/ Elohim ${ }^{37} / \mathrm{Allah}^{38}$ as a man, and portrays the latter within discourses also dominated by men.

Frances Klopper (2002: 423) states that "if we see God as a man or more like a man or more properly named in male language, we tend to think of men as more like God and women less like God" as women are associated with the fall. A worldview is created which sees the difference between men and women as an irreconcilable one and as stated by Daniel Boyarin “...this opposition lies at the root of every discursive practice" (1998: 117). These discursive practices by and large put women not only in a different but also in an inferior position, an argument which can be best followed by Judith Butler's (1993: 2) statement that "discourse produces the effects that it names."

This kind of a representation in which women are given an opposing and usually subordinating set of attributes ${ }^{39}$ in contrast to men also affected the perception of their role in reproduction. The medical texts from Ancient Mesopotamia constitute an example which illustrates that men were believed to be the only essential actors of reproduction as providers of semen, and this was seen as the sole instigator of conception. Since the internal dynamics of the female body were not observable for the people of Ancient Mesopotamia, it was believed that the woman's body had to be possessed and impregnated by the male agent. Frymer-Kensky (1992: 48) noted that "the role of males in reproduction had been understood at least since the domestication of animals (in 
the Near East, around $9000 \mathrm{BC}$ ). But the ovum is a very recent discovery, and biology, until early modern times, considered the male sperm to be the sole agent in engendering the child."

This view illustrates that the "feminine realm" of the motherhood narrative does not necessarily depict the active agency of women. Rather, the female body is conceptualised as a passive means of reproduction and serves a role similar to that of a carrier. The understanding about women's passive role in reproduction in Ancient Mesopotamia was paralleled also in the GraecoRoman world, where it was believed that "the mother is no parent of that which is called her child, but only nurse of the new planted seed that grows... a stranger, she preserves a stranger's seed..." (Frymer-Kensky 1992: 204)

Paradoxically, the role of men in the motherhood narrative was quite limited except their role of providing semen as the necessary means of reproduction (Hurwitz 2009: 110). Although paradoxical, this situation was in line with the bias of seeing motherhood as a solely female enterprise and put the responsibility of the dangers inherent in the motherhood narrative specifically on the shoulders of women. The presented examples of medico-religious discourses further strengthen this understanding by showing that the labour process was assisted by other women or midwives instead of male practitioners.

At the same time, reproductive heterosexual activity was valorised in Ancient Mesopotamia, in a fashion not quite different from the contemporary valorisation of motherhood. Reproduction was seen - as today - to be the main function of women in society and “...the woman was considered the eager recipient of the baby" (Frymer-Kensky 1992: 121). Women had to be seen as eager recipients since they became valuable and respectable only within the motherhood narrative, as opposed to barren or childless women, or illegitimate mothers, who constituted typologies for female evils as opposed to legitimate mothers.

The same discourses shaped the relation of women to each other and reinforced the difference between women and mothers: mothers as valuable and respectable females being opposed to "other" women, who basically serve no function. A vivid example of this difference is evident in witch-trials of the 17th century Germany where “...the accusations were made by women who experienced childbirth and their most common type of target was a post-menopausal, infertile woman who was caring for the infant." (Roper 1997: 204) This argument is further strengthened by Malcolm Gaskill who, referring to the stereotypes concerning witches, states that they were usually “...female, economically marginal and rarely had living husbands" (1996: 258). In this sense, mothers constituted the category of "proper women" who were "...expected to remain mostly at home and to leave their houses only on legitimate errands" (Frymer-Kensky 1992: 28). On the other hand, there were "other" women, 
who were not occupied with the usual social responsibilities of a woman, but were free from encumbrances and “...dangerous, fearsome and threatening because of [their] freedom" (Frymer-Kensky 1992: 29). These "others" were usually portrayed as temptresses - a stereotype which is still intact - who were not bound to a home or man, further emphasising the difference between women and mothers. "Other" women take the form of the female evils in the motherhood narrative and regardless of their portrayal as mothers themselves or sometimes as excessively fertile - as in the case of Lilith - they could generate only "demonic offspring" because of their illegitimate sexual activity. In short, they appear as the antitheses of "proper women" - their sexuality cannot be kept under control, they pursue whomever they wish, seduce men and lead them astray from their families, beget illegitimate offspring and kill the legitimate ones. In this sense, the female evils as the villains of the motherhood narrative represent the "untamed" part of women.

These women are malevolent and they trespass the suppressing boundaries. They cannot possibly be virtuous, thus, they also pose a castration threat to men ${ }^{40}$. This threat is posed by female evils in two ways: either they produce illegitimate offspring who cannot secure the continuation of the bloodline, or they kill the legitimate heirs. They can also cause impotence and infertility, or kill the men.

In either way, they serve as a means of distinguishing a "forbidden" category of women as Leach (1989: 45) notes with reference to Levi-Strauss that the control of female sexuality "...implies a capacity to distinguish between women who are permitted and women who are forbidden." The female evils represent the "forbidden" category of women who are not the virgins to be married and not the ones to become mothers. With their insatiable sexuality, the female evils are innately barred of being legitimate mothers in a motherhood narrative which excludes female sexuality.

Female evils, as antitypes of proper women, are anarchic figures who are not constrained by law, convention or sanity (Lesses 2004: 369). They are almost always the ones who disturb society.

\section{CONCLUSION: AND THEY WILL KEEP ON WHISPERING}

While motherhood is presented both as a goal for women and as the fulfilment of the female desire, it also involves a great burden for women. If a woman miscarries, gives stillbirth, or gives birth to a child with a certain disorder, it is possible that she becomes labelled as unfaithful, cursed or bewitched, or in any case, the legitimacy of the child may be questioned. Women always have to 
defend their respectability by staying within the boundaries defined for "proper women". They are suppressed into a defensive position by various discursive practices, of which the medico-religious one is an example. Within this framework, women's sexuality should remain unambiguous and under control. Otherwise, they can be ridiculed, labelled, outcast and even punished by both men, and other women.

Therefore, the fear is not only about the physiological complications inherent in the motherhood narrative, but also about their social implementations, all of which together create a great anxiety for women.

Today, the belief in sorcery and witchcraft has declined and modern medicine and psychiatry replaced medico-religious discourses in treating bodily and metal problems. With the same token, while the physiological complications in the motherhood narrative became the subject of modern medicine, the apparent symptoms of the aforementioned anxieties in women became the subject of psychiatry. These symptoms do not take the form of female wickedness anymore, and are instead defined as disorders, such as tokophobia (the fear of giving birth), hysteria and postpartum depression. The cause of women's "inexplicable" behaviour had to be rationalised even in the absence of a psychoanalytical discourse and at the times of repressed female sexuality, and thus the fears of women were projected onto the female evils. Although these evils have ceased to be regarded as the villains of the motherhood narrative, it is still the case, in Roper's words (1997: 212) that “...women today may attempt to use the defence of post-partum psychosis to argue that they were not legally responsible for crimes committed during the first few weeks after giving birth."

Female evils are not considered to be the major causes of "female problems" or the carriers of the plague in the contemporary world. However, this is a relatively recent development. As pointed out by Judit Blair (2005) our understanding of the cause of some diseases had been transformed only during the past hundred years, together with the knowledge of pathogenicity. This knowledge substantiated the existence of germs together with finding out their role in the transmission of diseases. These events facilitated the replacement of rituals and incantations by therapeutics and hygiene became the new means of protection.

Although it may seem that germs and bacteria have assumed the role which formerly belonged to female evils - carrying the plague and feeding poisonous milk to babies - they nevertheless continue their existence in the psyche and cultural imagery of today. They will keep on representing the "dark feminine" which still poses a castration threat as the uncontrollable, untamable, powerful side of women and also a double bind which still causes the discursive suppression of women. 


\section{NOTES}

1 Abjection is used here in a sense corresponding to that of Julia Kristeva (1982: 1), whereby abject means both a "tempting and condemned" being, which is simultaneously the object of desire and what that desire rejects.

2 There are complicated taboos placed on women in cultures as far apart as the Middle East and North America that saw menstruation as filthy and dangerous (Pollack 1997: 135; Black Koltuv 1990: 14). Rachel Biale states that there is a taboo on menstruating women in the world at large “... since many cultures share the same basic psychological components: fear of bleeding, discomfort with genital discharge, and bewilderment especially on the part of men, at the mysterious cycle of bleeding and its connection to conception and birth." (Biale 1984: 147)

${ }^{3}$ Luce Irigaray (1985b: 170) states that "the society we know, our own culture, is based upon the exchange of women... The passage into the social order, into the symbolic order, into order as such, is assured by the fact that men, or groups of men, circulate women among themselves, according to a rule known as the incest taboo."

4 The reference here is an "institution of motherhood" which is different from "motherhood as a personal and psychological process". The latter refers to "the potential relationship of any woman to her powers of reproduction and to children" (Fuchs 1985: 129) whereas the former refers "...to the mechanism aimed at ensuring that that potential - and all women - shall remain under male control" (Fuchs 1985: 129).

5 Women in the motherhood narrative are not seen as sexual agents but conceived within a fantasy which slightly corresponds to that of a "virgin-mother". Leach (1971: 107) states about such fantasies that "from many sources we learn of legends, traditions, ritual practices which seem to imply a belief that women may sometimes be pregnant by means other than insemination by a human male."

6 This is an analogy with the "dark side of the moon" since the moon represents feminine energy (Zingsem 2005: 92; Hurwitz 2009: 21). Correspondingly, the dark side represents the repressed aspects of the feminine, with a focus on female sexual energy and sexual activity. It also includes the destructive attitudes and the "murderous rage" of women as representations of the premenstrual syndrome, the rejection of motherhood, mother's possessiveness and hostility, jealousy and competitiveness towards other mothers (Black Koltuv 1986:10, 85; Zingsem 2005: 283, 287288; Fuchs 1985: 131).

7 This term is applied to texts produced by the rabbis in the late antiquity, regarding the centrality of the Torah (Neusner et al. 1999: 949).

${ }^{8}$ Hurwitz (2009: 46) also states that child-stealing, bloodsucking beings which could appear as seductive women can be found in the mythology of almost all peoples. $\mathrm{He}$ also notes that there were myths in which both aspects occurred simultaneously.

9 According to Jung (1958: 148f) this is "an irrepresentable factor, a disposition which starts functioning at a given moment in the development of the human mind and arranges the material of consciousness into definite patterns." In Jungian psychoa- 
nalysis, the "archetype" is the secret, collective, symbolic language that all of us recognise (Wolf 1998: xi).

${ }^{10}$ West discusses (1995: vii) that there is an evidence for Mycenaean trade and colonisation in the Orient, and for oriental trade and colonisation in the Aegean and Greece. There are also Semitic motifs in the Greek iconography and mythology and that some Greek names also had Semitic origins and origins in Mesopotamian mythology.

${ }^{11}$ Zeus is regarded as the greatest god of the Greek pantheon. He was essentially the god of light, of clear skies as well as of thunder (Grimal 1990: 453).

${ }^{12}$ Hera was the greatest of all the Olympian goddesses. She married Zeus in a formal wedding ceremony (Grimal 1990: 181).

${ }^{13}$ Hecate is a Graeco-Roman goddess, who originated from Lamaštu, and is originally chthonian and malevolent (West 1995: 316).

${ }^{14}$ Hurwitz (2009: 47) states that "in zoology, owls are commonly classified as Strigiformes. A subdivision consists of owls in the strict sense of the term, or Strigidae. To this group belongs the screech owl or Strix, known for catching small mammals."

${ }^{15}$ Hystera is a place, ground or dwelling, shaped like a cave or a womb (Irigaray 1985a: 243).

${ }^{16}$ Hurwitz (2009: 47-48) looked at different languages to trace particular similarities. He notes that "in Italian, the word strega means something akin to an old evil woman or witch, who is in league with the devil. In Old French, the word is estrie and means 'a vampire-like creature'. The Portuguese parallel, estria, means 'witch'. She corresponds to the Spanish bruja... But in all languages, so to speak, the word means a witch on the one hand and a predatory night owl on the other... But in non-Romanic languages, too, the striga is well-known. In the Balkans, her name is strygoi."

17 These bowls were found in the ruins of houses in a Jewish settlement in Nippur, corresponding to the southern part of Babylonia. Similar inscriptions have been found in different areas of the Middle East. Although the date of the manufacture of these bowls has not yet been definitely established, Hurwitz (2009: 90) notes that they might have been produced in the 6 th or 7 th centuries BC. The inscriptions on the bowls include Aramaic magic texts, which reflect the Jewish tradition of Babylonia of the time. These texts were published in 1913 (Hurwitz 2009: 90).

${ }^{18}$ Hurwitz, elaborating on the issues underlying this story notes that "the wife's demand for equality and autonomy must have appeared highly threatening to the male consciousness moulded by the spiritually-patriarchal cultural canons... [which not only holds good] for the consciousness of the Jewish man but is also typical of the whole of Western culture in the Classical period, the Middle Ages and, partially, in Modern times. It holds good equally for Christendom, Islam and Judaism." (Hurwitz 2009: 183)

${ }^{19} \mathrm{Yhwh}$ is the Biblical proper name of God. It consists of the letters yud, heh, vav, heh, which constitute the Tetragrammaton. It is interpreted as denoting eternal existence. It is the holiest of names and is never pronounced (Werblowsky \& Wigoder 1997: 278). 
${ }^{20}$ Black Koltuv (1986: 22) interprets this story as the claim of Lilith for equality with Adam since they were both created from dust or earth. She refused the activity and dominance of Adam and sought the freedom to move, act, choose and determine herself. Black Koltuv interprets Lilith as the quality in a woman that refuses to be bound in a relationship.

21 "And Lilith left Adam and went to seek her own place

And the gates were closed behind her and her name was

stricken from the Book of Life." (Sherman 1998: 355)

${ }^{22}$ The names of these angels may vary according to authors, as Senoi, Sansenoi and Semangloph in Hurwitz (2009: 120) or as Sanvai, Sansanvai and Semangelof in Black Koltuv (1986: 103).

${ }^{23}$ Lilith is a lively figure in today's popular culture especially in music and visual arts. Rivlin (1998: 390) gives a list of works and artists inspired by Lilith or bearing her name in the afterword to the book Which Lilith? Feminist Writers Re-Create the World's First Woman. Probably the most famous of these examples from popular culture is the Lilith Fair, a music festival held by female artists only, during the summers of 1997-1999 and revived in 2010.

${ }^{24}$ The jinn are an order of spirits lower than angels in Islamic mythology. They are said to have the power of appearing in human and animal forms and to exercise supernatural influence over man. They are mostly the servants of Iblis (the Devil) (Bonnerjea 1927: 123).

${ }^{25}$ Hurwitz (2009: 213) also mentions that Lilith, in the Zohar, was also portrayed as having red hair and a scarlet dress, in a similar fashion like that of Albastr. This colour also has psychoanalytic and symbolic implications which are not going to be discussed in detail.

${ }^{26}$ Both the aforementioned names Albastı and Al-Karısı can be divided into two parts: The adjective $A l$ constitutes the first part which means 'red colour, vermilion, crimson, flame scarlet' (İz 1992: 17; Redhouse 2004: 31) and is explained as the colour of blood. The second part is the verb 'basmak' which means 'attack suddenly, overpower, press, tread on, flood, over-flow, to descend on, cover' (İz 1992: 57; Redhouse 2004: 97). The combination of these two can be translated as 'to redden' or 'to get struck by red'.

${ }^{27}$ Bonnerjea (1927: 120) states that the jinn, the general category of beings to which Albast belongs, dread iron so much that even the name of this metal acts as a charm against Albastr. In European folklore, witches are also kept at bay by iron instruments.

${ }^{28}$ Albastı is a contemporary example of such personifications.

29 The earliest archaeological evidence includes medical texts dated around $2000 \mathrm{BC}$, from the Third Dynasty of Ur and written in Sumerian. The largest portion of these texts is Neo-Assyrian (Biggs 2005: 1). There are also numerous Babylonian medical texts from the Hittite capital of Khattusha near the modern village of Boğazköy in central Anatolia (contemporary Republic of Turkey) which are closely linked to the fewer number of Mesopotamian texts from the 2nd millennium. According to Robert Biggs (2005: 1) there are several word-for-word parallelisms of these texts, suggesting that the texts from Neo-Assyrian times may reflect the practices of nearly a 
millennium earlier. Although these texts present examples from Ancient Mesopotamia, parallelisms can be found between Mesopotamian medicine and the medical practice of Ancient Greece (Biggs 2005: 17).

${ }^{30}$ These treatments are the medical asûtu and the magical āšipūtu. It was apparent in the medical texts that the physician called as $\hat{u}$ and the magician called šipu, both male, had been working side by side on the same cases (Biggs 2005: 1). The practices of the asu and the āšipu both included the usage of amulets and incantations for protection from harmful beings.

${ }^{31}$ Talmud is the Hebrew word for 'study'. It is the most important work of the Oral Torah (Unterman 1991: 194).

${ }^{32}$ Torah is the Hebrew word for 'teaching'. It is one of the central concepts of Judaism, which may refer to the Ten Commandments, the Hebrew Bible, or the whole of Jewish Tradition in its widest sense (Unterman 1991: 200).

${ }^{33}$ Ogden (1999: 3-4) states that there are 1.600 currently known tablets from various sites, most of which are written in Greek, and another significant part in Latin. The earliest batch of 22 Greek tablets is from the Greek colony of Selenius in Sicily, dating from the early 5th century BC. The majority of all known curse tablets were found in Attica, ranging throughout the classical, Hellenistic and imperial periods. The phenomenon of curse tablets flourished between the 2 nd and 5 th centuries BC (Ogden 1999: 61).

${ }^{34}$ These female evils attached themselves to men and getting rid of them was possible only through a ritual of divorce. They acted as if they were married to men and acquired rights of cohabitation, while they prevented men from having benign sexual intercourse with their lawful wives (Hurwitz 2009: 100), or caused impotency.

${ }^{35}$ Jupiter is the sovereign divinity of the Romans, originally a sky-god who has supreme power over other gods and men. He was identified with the Greek Zeus, and adopted Zeus's mythology as his own (March 2001: 403).

${ }^{36}$ The most famous example of this influence is the image of a bearded Creator painted by Michelangelo on the ceiling of the Sistine Chapel in the Renaissance period.

${ }^{37}$ Elohim is a plural form, but it is used in a singular form when referring to the God of Israel. The proper name Yhwh is not used in order to "avoid taking the name of the Lord in vain" (Werblowsky \& Wigoder 1997: 278).

${ }^{38}$ Allah is the Arabic name for God. The name was known in pre-Islamic Arabia as the head of the pantheon among polytheists and as the name for God among Arabicspeaking Christians and Jews. With the advent of Islam, Allah was defined as "the One", eternal, neither born nor bearing and not having an equal (Newby 2002: 26).

${ }^{39}$ Men are seen as the creators of culture, they are rational, trustworthy, strong, active, vigorous, honourable, courageous, combative, independent, dominant, heroic and sadistic. Women, on the other hand, are seen as close to nature, they are emotional, sentimental, weak, grieving, passive, beautiful, alluring, protective, nurturing, dependent, submissive, cowardly, deceptive, confined, altruistic and masochistic (Black Koltuv 1986: 22; Fuchs 1985: 121).

40 They pose this threat because they represent the loss of domination and manhood (Hurwitz 2009: 220-221, 230). 


\section{REFERENCES}

Acıpayaml, Orhan 1974. Türkiye'de Doğumla İlgili Adet ve İnanmaların Etnolojik Etüdü. [An Ethnological Study of Birth Related Traditions and Beliefs in Turkey.] Ankara: Sevinç Yayınları.

Ann, Martha \& Imel, Dorothy Myers 1993. Goddesses in World Mythology:A Biographical Dictionary. Santa Barbara: ABC-CLIO.

Bell, Robert E. 1991. Women of Classical Mythology:A Biographical Dictionary. California: ABC-CLIO.

Biale, Rachel 1984. Women and Jewish Law: The Essential Texts, Their History \& Their Relevance for Today. New York: Schocken Books.

Biggs, Robert D. 2005. Medicine, Surgery, and Public Health in Ancient Mesopotamia. Journal of Assyrian Academic Studies, Vol. 19, No. 1, pp 1-19.

Black Koltuv, Barbara 1986. The Book of Lilith. Lake Worth: Nicolas-Hays.

Black Koltuv, Barbara 1990. Weaving Woman: Essays in Feminine Psychology from the Notebooks of a Jungian Analyst. Maine: Nicolas-Hays.

Blair, Judit 2005 From Demons to Germs. Studia Universitatis Babes-Bolyai-Theologia Catholica Latina, No. 2, pp. 111-121.

Bonnerjea, Biren 1927. A Dictionary of Superstitions and Mythology. London: Folk Press.

Boratav, Pertev Naili 1973. Yüz Soruda Türk Folkloru: Inanışlar, Töre ve Törenler, Oyunlar. [Turkish Folklore in 100 Questions: Beliefs, Customs, Rituals and Games.] İstanbul: Gerçek.

Boyarin, Daniel 1998. Gender. In: M. C. Taylor (ed.) Critical Terms for Religious Studies. Chicago: University of Chicago Press.

Broedel, Hans Peter 2003. The Malleus Maleficarum and the Construction of Witchcraft. Manchester: Manchester University Press.

Butler, Judith 1993. Bodies That Matter. New York: Routledge.

Calmet, Dom Augustine 1993. Treatise on Vampires and Revenants: The Phantom World. Brighton: Desert Island Books.

Cantor, Aviva 1998. Lilith, the Woman Who Would Be a Jew. In: E. Dame \& L. Rivlin \& H. Wenkart (eds.) Which Lilith? Feminist Writers Re-Create the World's First Woman. Northvale: Jason Aronson.

Coulter, Charles Russell \& Patricia Turner 2000. Encyclopedia of Ancient Deities. London: McFarland \& Co.

Çay, Abdülhalûk 1983. Anadolu'da Türk Damgası. [The Turkish Imprint on Anatolia.] Ankara:T.K.A.E.

Çobanoğlu, Özkul 2003. Türk Halk Kültüründe Memoratlar ve Halk İnançları. [Supernatural Tales and Folk Beliefs in Anatolian Folk Culture.] Ankara: Akçağ Yayınlart.

Doğan, Mehmet 1981. Büyük Türkçe Sözlük. [Grand Turkish Dictionary.] Ankara: Birlik Yayınları.

Eyuboğlu, İsmet Zeki 1998. Anadolu İnançları: Anadolu Üçlemesi - 1. [Anatolian Beliefs: The Anatolian Trilogy - 1.] İstanbul: Toplumsal Dönüşüm Yayınları.

Frymer-Kensky, Tikva 1992. In the Wake of the Goddesses: Women, Culture, and the Biblical Transformation of Pagan Myth. New York: Macmillan. 
Fuchs, Esther 1985. The Literary Characterization of Mothers and Sexual Politics in the Hebrew Bible. In: A. Y. Collins (ed.) Feminist Perspectives on Biblical Scholarship. Atlanta: Scholars Press.

Gaskill, Malcolm 1996. Witchcraft in Early Modern Kent: Stereotypes and the Background to Accusations. In: J. Barry \& M. Hester \& G. Roberts (eds.) Witchcraft in Early Modern Europe: Studies in Culture and Belief. New York: Cambridge University.

Gennaro, Alfonso R. 1979. Blakinston's Gould Medical Dictionary. New York: McGrawHill.

George, Andrew R. \& Finkel, Irving (eds.) 2000. Wisdom, Gods and Literature: Studies in Assyriology in Honour of W. G. Lambert. Indiana: Eisenbrauns.

Gordon, Richard 1999. Imagining Greek and Roman Magic. In: B. Ankarloo \& S. Clark (eds.) Witchcraft and Magic in Europe: Ancient Greece and Rome. Philadelphia: University of Pennsylvania.

Gökbel, Ahmet1998. Anadolu Varsaklarında İnanç ve Adetler. [Beliefs and Traditions of Anatolian Varsaks.] Ankara: Atatürk Kültür Merkezi Başkanlığı.

Grant, Michael \& John Hazel 1993. Who's Who in Classical Mythology. London: J. M. Dent.

Grimal, Pierre 1990. The Concise Dictionary of Classical Mythology. Oxford: Basil Blackwell.

Grimal, Pierre 1996. The Dictionary of Classical Mythology. Oxford: Basil Blackwell.

Hester, Marianne 1996. Patriarchal Reconstruction and Witch Hunting. In: J. Barry \& M. Hester \& G. Roberts (eds.) Witchcraft in Early Modern Europe: Studies in Culture and Belief. New York: Cambridge University.

Hurwitz, Siegmund 2009. Lilith - The First Eve: Historical and Psychological Aspects of the Dark Feminine. Zurich: Daimon.

Irigaray, Luce 1985a. Speculum of the Other Woman. New York: Cornell University Press.

Irigaray, Luce 1985b. This Sex Which is not One. New York: Cornell University Press. İz, Fahir 1992. The Oxford Turkish Dictionary. New York: Oxford University Press.

Jung, Carl Gustav 1958. A Psychological Approach to the Dogma of the Trinity. In: C. G. Jung Psychology and Religion: West and East. New York: Pantheon Books.

King, Francis X. 1987. Witchcraft and Demonology. London: Exeter Books.

Klopper, Frances 2002. Women, Monotheism and the Gender of God. In Die Skriflig, Vol. 36, No. 3, pp. 421-437.

Kristeva, Julia 1982. Powers of Horror: An Essay on Abjection. New York: Columbia University Press.

Leach, Edmund 1971. Genesis as Myth and Other Essays. London: Jonathan Cape.

Leach, Edmund 1989. Claude Lévi-Strauss. Chicago: University of Chicago.

Leick, Gwendolyn 1998. A Dictionary of Ancient Near Eastern Mythology. London: Routledge.

Levi, Primo 1995. Moments of Reprieve. New York: Penguin.

Lesses, Rebecca 2004. Exe(o)rcising Power: Women as Sorceresses, Exorcists, and Demonesses in Babylonian Jewish Society of Late Antiquity. Journal of the American Academy of Religion, Vol. 69, No. 2, pp. 343-376. 
Luck, Georg 1999. Witches and Sorcerers in Classical Literature. In: B. Ankarloo \& S. Clark (eds.) Witchcraft and Magic in Europe: Ancient Greece and Rome. Philadelphia: University of Pennsylvania.

March, Jenny 1999. Cassel Dictionary of Classical Mythology. London: Cassell.

March, Jenny 2001. Cassel Dictionary of Classical Mythology. London: Cassell.

Martin, E. A. 1994. Concise Medical Dictionary. New York: Oxford University Press.

Maxwell-Stuart, P. G. 2004. Witchcraft: A History. Stroud: Tempus.

Neusner, Jacob \& Avery-Peck, Alan J. \& Green, William Scott (eds.) 1999. The Encyclopedia of Judaism, Vol. II. Leiden: E. J. Brill.

Newby, Gordon D. 2002. A Concise Encyclopedia of Islam. Oxford: Oneworld.

Ogden, Daniel. 1999. Binding Spells: Curse Tablets and Voodoo Dolls. In: B. Ankarloo \& S. Clark (eds.) Witchcraft and Magic in Europe: Ancient Greece and Rome. Philadelphia: University of Pennsylvania.

Osiek, Carolyn 1985. The Feminist and the Bible: Hermeneutical Alternatives. In. A. Y. Collins Feminist Perspectives on Biblical Scholarship. Atlanta: Scholars.

Patai, Raphael 1969. The Hebrew Goddess. New York: Ktav Publishing House.

Phipps, William E. 1989. Genesis and Gender: Biblical Myths of Sexuality and Their Cultural Impact. New York: Praeger.

Pollack, Rachel 1997. The Body of the Goddess: Sacred Wisdom in Myth, Landscape and Culture. Massachusetts: Element.

Püsküllüoğlu, Ali 2003. Türkçe Deyimler Sözlüğ̈̈. [Dictionary of Turkish Idioms.] Ankara: Arkadaş Yayınları.

Raudvere, Catharina 1996. Now You See Her, Now You Don't: Some Notes on the Conception of Female Shape-shifters in Scandinavian Traditions. In: S. Billington \& M. Green (eds.) The Concept of the Goddess. London: Routledge.

Redhouse English-Turkish / Turkish-English Dictionary 2004. İstanbul: Sev Yayınları.

Rivlin, Lilly 1998. Afterword: Lilith Lives. In: E. Dame \& L. Rivlin \& H. Wenkart (eds.) Which Lilith? Feminist Writers Re-Create the World's First Woman. Northvale: Jason Aronson.

Roberts, Gareth 1996. The Descendants of Circe: Witches and Renaissance Fictions. In: J. Barry \& M. Hester \& G. Roberts (eds.) Witchcraft in Early Modern Europe: Studies in Culture and Belief. New York: Cambridge University

Roper, Lyndal 1997. Oedipus \& the Devil: Witchcraft, Sexuality and Religion in Early Modern Europe. London: Routledge.

Scholem, Gershom 1974. Kabbalah. New York: Dorset.

Scurlock, JoAnn 2006. Magico-Medical Means of Treating Ghost-Induced Illnesses in Ancient Mesopotamia. Leiden: Brill.

Sherman, Susan 1998. Lilith of the Wildwood, of the Fair Places. In: E. Dame \& L. Rivlin $\&$ H. Wenkart (eds.) Which Lilith? Feminist Writers Re-Create the World's First Woman. Northvale: Jason Aronson.

Stedman, Thomas Lathorp 1995. Stedman's Medical Dictionary. Baltimore: Lippincott Williams \& Wilkins.

Tucker, Holly 2003. Pregnant Fictions: Childbirth and the Fairy Tale in Early Modern France. Detroit: Wayne State University Press.

Unterman, Alan 1991. Dictionary of Jewish Lore and Legend. London: Thames \& Hudson. 
Werblowsky, Zwi Raphael Jehudah \& Wigoder, Geoffrey 1997. The Oxford Dictionary of the Jewish Religion. New York: Oxford University.

West, David R 1995. Some Cults of Greek Goddesses and Female Daemons of Oriental Origin. Darmstadt: Verlag Butzon \& Bercker Kevelaer.

Wolf, Naomi 1998. Introduction. In: E. Dame \& L. Rivlin \& H. Wenkart (eds.) Which Lilith? Feminist Writers Re-Create the World's First Woman. Northvale: Jason Aronson.

Zingsem, Vera 2005. Lilith:Adem’in İlk Karısı. [Lilith: Adam's First Wife.] İzmir: İlya. 


\title{
FOLK NARRATIVES AND LEGENDS AS SOURCES OF WIDESPREAD IDIOMS: TOWARD A LEXICON OF COMMON FIGURATIVE UNITS
}

\author{
Elisabeth Piirainen
}

\begin{abstract}
The subject matter of this article is widespread idioms originating from folk tales and old legends that once were elements of the folklore of various European language communities but later fell into oblivion. The motifs of these tales survived in currently known idioms of many languages of Europe and beyond and thus contribute to constituting a part of the Lexicon of Common Figurative Units.
\end{abstract}

Key words: animal tales, comical stories, common figurative units, fables, folk narratives, intertextuality, languages of Europe, legends, Schwundstufe, widespread idioms

\section{NARRATIVES AND FIGURATIVE UNITS OF THE LEXICON}

It is a well-known fact in folklore and paremiology that various genres of verbal folklore like fairy tales, legends, riddles etc., on the one hand, and figurative units of the lexicon (i.e. proverbs and proverbial phrases, the latter also known as idioms) on the other, are often inextricably interrelated with each other. Several studies have been devoted to the interrelation between narratives and their "zerograde" truncated forms (German Schwundstufe) in proverbs and idioms (e.g. Röhrich 1960; Mieder 1986), and the mutual relationship between proverbial expressions and narratives, especially fables, has been a matter of intensive semiotic and inter-textual research (cf. Perry 1959; Permiakov 1979, Grzybek 1989; Carnes 1988, 1991, among others). A tale in its simplest form can be identical with a proverb, with the relationship going in both directions. On the one hand, stories (particularly fables) have been derived from already existing proverbs, from antiquity up to early modern times. On the other hand, a story in its summarised form can live on in a proverb or an idiom, even if the knowledge of this story has been forgotten for a long time. 
It is generally less known that there are various idioms of this latter kind: idioms originating from allusions to folk narrations, comical tales, legends, etc., which once were widespread and well-known across several European languages but fell into oblivion in the course of history. These narratives (i.e. their truncated forms) survived not only in idioms of some individual languages but in almost "similar" idioms of a large number of present day languages of Europe and beyond.

\section{WIDESPREAD IDIOMS IN EUROPE AND BEYOND}

Cross-linguistic lexical-semantic "similarities" of the idioms of some languages have now and then come to the notice of phraseology researchers but have not been studied systematically until recently. The similarities are usually explained as contact-induced borrowings from one language into the other. Even more: according to a persistent misconception, the tendency of languages to converge with respect to their idioms is seen as a sign of the increasing influence of the English language in the wake of the so-called globalisation. Whether the uniformity of idioms across different languages is related to the influence of English in our times or has completely different causes can only be determined by means of data gained from comprehensive research on a large number of languages. Some of the results, that emerged from the international project Widespread Idioms in Europe and Beyond, over the last few years, may be regarded as one small contribution in this area.

One of the goals of the project was to identify the core inventory of idioms that exist in many European languages (and beyond) in the same or a very similar lexical and semantic structure. First, a theoretical framework and a suitable meta-language had to be developed (cf. Piirainen 2009, 2010). The next objective was to systematically discover widespread idioms (WIs) across as many languages as possible. Unlike the cross-linguistic phraseology which usually focuses on two or three randomly selected languages, all European languages accessible to idiom research were included. For this purpose, a network of competent collaborators was established, and questionnaires with potentially "common European idioms" were sent to about 250 experts of various languages. We have received data for 73 languages spoken in Europe, among them 55 Indo-European, 11 Finno-Ugric ${ }^{1}$ and five Turkic languages as well as Maltese, Georgian and Basque, including 41 major and 32 lesser-used languages.

It was completely unpredictable which of the idioms would actually be widespread and which would fall short of our criteria. The questionnaires produced about 360 units that are truly widespread across 40, 50 or more languages of Europe and beyond. This set of idioms was then categorised according to their 
historical origins, i.e. their cultural foundations and the chronological layers to which they may be assigned. It turned out that a large number of WIs had already been widespread from the Middle Ages and following centuries onwards. The number of WIs, rooted in a genuinely modern layer and which may be traced back to recent Anglo-American influence, seems to be very small.

The main goal of the project is now to compile the data, given by our informants on the background of this historical-etymological classification, in order to create a lexicon of the widespread idioms which we call the Lexicon of Common Figurative Units ${ }^{2}$ (cf. Piirainen forthcoming).

\section{COMMON FIGURATIVE UNITS AND INTERTEXTUALITY}

Further details resulted from this cultural-historical assignment of each widespread idiom: more than half of the entire inventory of our "common European idioms" (about $177 \mathrm{WIs}$ ) falls under the umbrella term of intertextuality. By this we understand the relationship of an idiom with an already existing, mostly identifiable text as its cultural and historical origin. Several types of intertextuality can be distinguished, depending on whether the connection between the textual source and the idiom is close or rather loose.

First, there are direct quotations from an individual text which gradually developed into idioms but still can be identified as literary fragments by their wordings, for the most part. Widespread idioms of this provenance range from quotations from classical authors (e.g. to combine business with pleasure, tracing back to Horace's De Arte Poetica, verse 343) or biblical verses (by the sweat of one's brow, Genesis 3:19) to various literary works (much ado about nothing, the title of Shakespeare's comedy).

The second group is not as easy to single out, namely widespread idioms precursors of which were in circulation as early as in ancient times. The simultaneous occurrence of a given saying, in several ancient sources, is a sure indication that it was already proverbial at that time. A prominent example is the idiom the die is cast, which is often regarded as an utterance coined by Caesar. As the sources show, Caesar did not create but quoted this phrase which is in fact much older, already current and understood in its figurative meaning in Greek antiquity. ${ }^{3}$ This second group includes WIs of biblical origin, used proverbially in the Bible itself.

The largest number of intertextually related WIs, however, goes back to once well-known stories, summarising a certain text passage or the general idea of a text (cf. the first section). This form of intertextuality is particularly important for the development of common European idioms. The knowledge 
of the narratives, side by side with the proverbial phrases, has greatly supported their wide dissemination. Let us briefly consider the different types of stories which have mainly contributed to the widespread use of idioms, before we will have a closer look at WIs originating from post-classical folk narratives and old legends.

About ten idioms, popular in many current European languages, are rooted in Greek mythology; they are allusions to legends about gods and heroes, events surrounding the Trojan War or the Herculean tasks, as recorded by Greek and Roman poets (to be the Achilles' heel; to sweep the Augean stables; like the sword of Damocles hanging over sb.). Little attention has been paid to idioms originating in other types of stories that have been frequently retold since antiquity, such as the WI (to know) the place where the shoe pinches. It is an allusion to Plutarch's comical tale (told in the Coniugalia Praecepta, ca. $22 \mathrm{AD}$ ) about the Roman Aemilius Paulus who was blamed for divorcing his wife, with whom he seemed to have lived happily, and answered "no one knows where the shoe pinches like the wearer".

Various Bible stories, particularly from the Old Testament, contributed to the oldest layer of common European idioms (forbidden fruit; to worship the golden calf; to have feet of clay). Furthermore, several currently well-known WIs are documented in tales of both antiquity and the Bible, which indicates that the phrases were already widely known in the Hellenistic cultural area (e.g. a wolf in sheep's clothing which goes back to Aesop's fable and gained wide dissemination by the Sermon of the Mount, when Jesus refers to a similar fable, Matthew 7:15).

Other narrative sources of common European idioms are fables of the Aesopic type (to strut in borrowed plumes; to enter the lion's den; to fish in troubled waters), fairy tales, which are partly treated as literature (to be a bird in a gilded cage; to run with seven-league boots; an ugly duckling), and post-classical works of world literature (the most prominent WI of this provenance is to tilt at windmills which summarises the gist of Cervantes' famous novel Don Quixote). In contrast to all these (partly well-known) literary sources the traditions of folk tales as foundation of common European idioms have been ignored for the most part.

\section{WIDESPREAD IDIOMS IN FOLK TALES AND LEGENDS}

This section deals with widespread idioms that can mainly be attributed to various traditions of folk narration, partly post-classical tales, although parallels in works of antiquity may well exist. These idioms originate from allusions to stories that once were widespread but fell into oblivion. The stories, how- 
ever, survived in their truncated form in very well known idioms of many current languages. Among the 177 widespread idioms that developed by means of intertextuality, the group of WIs rooted in popular narratives is rather small. We can distinguish three groups, following the underlying type of story, namely idioms that chiefly go back to traditional jests and comical tales, to once popular animal tales and to old myths and legends which resulted in concepts of fabled animals. What the three groups have in common is the fact that not only the idioms are widespread but that the motifs of the tales themselves are elements of the folklore of various European language communities.

For reasons of space short comments on the linguistic specifics of the WIs (their structure and figurative meaning) will be given in smaller type. We will present the full data only for three examples (see the Appendix). In the other cases, we restrict ourselves to a small selection of idiom equivalents across the languages. There is no English equivalent of the idioms (3-4); here the German version will be quoted.

\section{Jests and comical tales}

The idioms (1-6) can be traced back to jester's tales and the "topsy-turvy world", where fools try the impossible (adýnaton) and nonsensical things take place. Idiom (1) is a good example to illustrate how the interaction between narratives and old proverbs can lead to the birth of a greatly widespread idiom.

\section{(1) to carry water in a sieve}

'to try to achieve a goal by using a totally inappropriate tool which inevitably leads to failure and seems very strange and unusual'

There are diverse folktales that tell the story of a hero who is forced to solve the impossible task of catching and carrying water in a sieve (or a leaky vessel, a basket). This old motif is spread across Europe (cf. Grimms' folktale Master Pfriem, KHM No. 178) and can also be identified in the Greek myth of Hades, where the daughters of Danaos had to scoop water into a jar that had holes in it. Thus, the origins of the idiom lie in a variety of narrations and proverbs that were common throughout the ancient world and the Middle Ages. ${ }^{4}$ Equivalents of the idiom as well as the textual sources behind it were spread across Europe in the early times.

The broad figurative meaning given above encompasses several partly diverging aspects. The idioms of different languages vary with respect to the individual aspects of this meaning that they highlight, which may be due to the diverse strands of tradition of the underlying narrative motif. The idioms show some lexical variation in the verb phrase (CARRY and SCOOP), while the nouns WATER and SIEVE are mostly invariant. Here are some examples, all meaning literally 'to carry (the) water in/with a sieve': Swedish bära vatten $i$ ett såll, German Wasser in einem Sieb tragen, Romanian a căra apă cu 
ciurul, Lithuanian sietu vandeni nešioti, Russian носить воду решетом, Slovak nosit' vodu v koši, Sorbian z křidu wodu nosyć, Albanian merr ujë me shoshë, Estonian sõelaga vett kandma, Tatar иләк белән су ташу, Azerbaijani süzqəcdə su daşımaq.

\section{(2) to put the cart before the horse}

'to put things in the wrong order or set the wrong priorities, to mistake the effects for the cause, to reverse the right or natural order of things'

Idiom (2) belongs also to the context of a "world turning upside down", where senseless and ludicrous things take place. The scenario of putting a horse or an ox behind the cart, or the cart before the team, was a popular folklore motif. It occurs in the Carmina Burana and other texts, also in the Grimms' folktale Master Pfriem (cf. (1)) in which in a man's dream horses are harnessed to the back of a wagon. The motif can also be found on tapestries and misericords in late medieval art. As proverbial phrases, similar images have been used in various languages since the Middle Ages. Ancient proverbs and narrations linked to this motif may have supported its wide distribution. ${ }^{\mathbf{5}}$

The data collected by our informants show that the languages focus on either the HORSE or the oxen concept. The first group of idioms can be roughly translated by 'to put/ harness the cart/carriage before the horse': Norwegian spenne vogna foran hesten, German den Wagen vor das Pferd spannen, Russian запрягать телегу впереди лошади, Czech zapřahat konĕ za vi̊z, Hungarian lovak elé fogja a kocsit, Moksha Mordvin крандазтьфталу алашать кильдемс. The next idioms can be roughly translated by 'to put the cart before the oxen': Breton eno e oa an denn war-lerc'h an arar, French mettre la charrue devant les bœufs, Occitan bitâ el shariô dran dlou biô̂, Romansh metter il char avant ils bovs, Spanish poner antes el carro que los bueyes, Romanian a pune carul înaintea boilor, Albanian vë parmendën para qeve.

(3) den Ast absägen, auf dem man sitzt ('to saw off the branch upon which one is sitting'), i.e. 'to deprive oneself of the basis for one's livelihood; to lose out through one's own fault'

The old comical tale of a man sitting on the branch of a tree and cutting it off was well-known since the Middle Ages in many European languages, ranging from Finnish to Greek and from Livonian to Spanish. ${ }^{6}$ Idiom (3) is often listed together with other proverbial phrases that express foolish actions harmful to oneself and are reported by Roman authors (e.g. "to knock the bottom out of one's own ship" or “to burn one's own harvesting”, cf. Spalding 1959: 77). The core of this story can be recognised in the rich image evoked by the complex sentence of all idiom equivalents.

The idioms of most languages can be literally translated as 'to saw off the branch sb./ you/one(self) is/are sitting on', e.g. Icelandic saga greinina sem e-r situr á, Dutch de tak afzagen waarop men zit, Italian si taglia il ramo su cui si siede, Aromanian sh-talje lumachia pi cai shade, Latvian (no)zāgét zaru, uz kura pats sē, Belorussian пілаваць 
сук, на якім сядзіш, Czech podřiznout si větev, na které sedí, Serbian сећи грану на којој седиш, Estonian seda oksa saagima, millel istud. Somewhat different verbs are used in Lithuanian kirsti šaką, ant kurios sed $i$ 'to cut off the branch oneself is sitting on', Polish podcinać gałąź, na której si siedzi 'to prune the branch you are sitting on' or Georgian ra totzets zis, imas jriso 'he cuts off the branch he is sitting on' and Romanian $a$-şi tăia craca de sub picioare 'to cut off the branch below the legs'. Deviant structures have also been reported for Slovak pílie konár pod sebou 'to saw off the branch below oneself' and Hungarian (ön)maga alatt vágja a fát 'sb. cuts down the tree under him/ her(self)'.

(4) mit Kanonen auf Spatzen schießen ('to fire at sparrows with cannons'), i.e. 'to use disproportionate means on an insignificant matter; to take stronger action than is necessary to deal with a problem or situation'

The exact origins of this idiom are unclear. Most probably it is connected to old folktales about a fool who tries to kill a fly (flies, bees, etc.) with an unsuitable instrument (axe, cannon, sword or gun) and accidentally kills the person whom the insect had been bothering. ${ }^{7}$ In medieval times, similar expressions are recorded for Italian, French and English, where the animal is not a sparrow but a fly (TPMA 3, 296), as is the case in the tales. The idea is that of someone attacking a very small creature with an inappropriately heavy weapon, e.g. with a sword, a crossbow or a falcon, and causing damage.

Our informants have cited variants with the concepts FLY and MOSQUITO for present times, e.g. Dutch met een kanon op een vlieg / mug schieten, West Frisian mei in kanon op in mich sjitte or Spanish matar moscas a cañonazos and Macedonian убива муви со топ, both meaning literally 'to kill flies with cannons', and Finnish ampua tykillä hyttysiä 'to shoot mosquitoes with a cannon'. ${ }^{8}$ Most other idioms literally mean 'to shoot/fire with cannons/with a cannon at sparrows', e.g. Swedish skjuta sparvar med kanon(er), French brûler sa poudre aux moineaux 'to fire one's powder at sparrows', Ladin ti stlopetè cun canuns ai spoc, Romansh trair cun chanuns sin paslers, Italian sparare ai passeri con un cannone, Lithuanian šaudyti iš patrankos $i$ žvirblius, Russian стрелять из пушки по воробьям, Slovak ist's gul'ometom na vrabce 'to go with machine gun against sparrows', Macedonian убива муви со топ 'to kill flies with cannon', Hungarian ágyúval lö verébre, Moksha Mordvin кирьхкснень/озяснон лангс пушкаса ляцендемс 'to fire one's powder for sparrows'.

(5) to sell the skin before you have caught the bear

'to count on future benefits that may never materialise; to divide expected profits etc. from a job that has not yet been accomplished'

The idiom refers to an old anecdote that was retold by La Fontaine (Fables V, 20) but later fell into oblivion. It is the tale of two travelling hunters who want to pay for their lodging with the skin of a bear that has been seen in the area but has not been shot yet. The story (erroneously ascribed to Aesop) appeared 
in print for the first time in Lorenzo Astemio's (Laurentius Abstemius') Hecatomythium in 1492 (cf. Wesselski 1928: 88-107). The equivalents of the idiom are dated or obsolete in some languages. Following the image of the tale, they have partly preserved the complex sentence structure. In Slovak, the concept BEAR has been replaced by WOLF.

Here are some examples: Icelandic selja skinnið áður en björninn er unninn 'to sell the skin before a bear has been overcome', Swedish sälja skinnet innan björnen är skjuten and Dutch de huid verkopen voor de beer geschoten is, both 'to sell the skin before the bear is shot', French vendre la peau de l'ours avant qu'on ne l'ait pris and Italian vender la pelle dell'orso prima d'averlo preso, both 'to sell the skin of the bear before one has got it', Spanish vender la piel del oso antes de cazarlo 'to sell the bear's skin before hunting it', Romanian a vinde blana ursului din pădure 'to sell the skin of the bear in the forest', Latvian (sa)dalīt nenošauta lāča ādu 'to share (out) the skin of a bear that has not been shot', Russian делить шкуру неубитого медведя 'to deal the skin of the not-killed bear', Slovak predávae kožu vlka, ke ho ešte nechytili 'to sell the skin of the wolf before one has got it', Hungarian elöre iszik a medve börére 'sb. drinks on the skin of the bear in advance', Estonian laskmata karu nahka jagama 'to deal the skin of the not-killed bear'.

\section{(6) to look for a needle in a haystack}

'to look for something that is impossible to find; to be bothered with searching without any prospect of success'

There are many folktales of vain searches for objects. Probably, the idiom refers to one of them, although the story of a fool who is hunting for a needle in a haystack is not as widespread. Grimms' fairy tale Clever Hans (KHM No. 32 ) tells about a fool who puts a needle into a hay cart. Here we want to point to the Yiddish idiom (Appendix 1) which uses the concept HAYWAGON. There may be a connection with an old proverb (Si acum quaereres, acum invenisses 'Who wants to search a needle, would also find it', reported by Plautus and Menander 238), although the element HAY is missing here. ${ }^{9}$

The full data reported by our informants are presented in the Appendix 1 below, illustrating that idiom equivalents are remarkably widespread. They exist not only in most of the European standard languages but also in a number of the minor and minority languages and even in some non-European languages. The causes of the "popularity" of this idiom in all these languages are still unclear. It is most probable that the idioms go back to one and the same textual source, although this source has not been established definitely.

Two further widespread idioms belong in the context of "the world upside down" and comical tales. Both idioms have been the topic of comprehensive studies. Therefore, it is sufficient to point to these studies here. The first WI, to build castles in the air 'to make unrealistic plans for the future, to have unfounded hopes and expectations', has several sources; one of them is a folktale, spread 
all over Europe in different versions. The story is about persons, lost in their daydream, who make great plans for the future but quarrel over details and lose everything (see Mieder 2010 for details).

Trokhimenko (1999) investigates into the second idiom, wie ein Elefant im Porzellanladen ('like an elephant in a china shop'), i.e. 'behaving in a rude way, causing damage by one's clumsy behaviour'. It may be rooted in tales about a man and his donkey entering a potter's shop, and various proverbs related to this story, well-known in antiquity.

\section{Animal tales}

Animal tales are traditional folk stories in which animals act like human beings. Unlike animal fables in Greco-Roman antiquity (fables of the Aesopic type), they were told for their own sake, as entertainment. Fables of the Aesopic type are distinguished by their moralising intention. The purpose of these fables is to illustrate a truth by means of a story. It is for this reason that Ben Edwin Perry (1959: 20ff) considers animal tales and fables two very different forms of art and products of different cultures. In our material there are some widespread idioms that most probably go back to once well-known animal stories, otherwise their wide distribution across the European languages and beyond cannot be explained, cf. (7).

\section{(7) to belfight like cat and dog}

'(of two people who know each other well) to frequently have violent arguments with each other, to keep quarrelling and get very angry with each other most of the time'

The motivation of this idiom may be seen in the observation of animal behaviour: it gives the impression that both animals are constantly arguing. However, the rivalry between cats and dogs is the topic of various once well-known European narratives in which the animals are said to have been friends at one point but certain events have led to their enmity. The story is at the same time an "etiological tale", i.e. it gives account of animals' behaviours, for example "as from now on, cat and dog are each other's worst enemies." 10 The idiom is already richly documented in medieval texts of various vernacular languages (see TPMA 6, 273ff).

See Appendix 2 for the full data. The idiom is exceptionally widespread. There are records for equivalents in at least 68 European languages, among them most of the lesser used languages that we analysed (the Inari Saami idiom was reported as a loan translation from Finnish) as well as several non-European languages. Variants are restricted to the constituent inversion, which is normal for similar binomials across languages, and the choice of verb. Our informants have listed a number of different 
verbs (to be / live / behave / quarrel / understand each other, etc.). Only a selection of them has been presented below. A truncated form (like cat and dog) and nominalised form ( $a$ cat-and-dog life 'a life of frequent or constant quarrelling') exist as well.

\section{(8) to play cat and mouse (with sb.)}

'to stall someone off, letting him/her wait for a (negative) decision; to alternate harshness and leniency in one's treatment of a helpless victim'

The roots of this idiom lie in the observation of animal behaviour: cats tend to play with the living mice they caught for quite a while, letting them go a foot or so away and then catching them again before killing their prey for good. The cat's play with a mouse, its physical superiority, which is set against the intellectual superiority of the mouse, has been the topic of various folk tales (such as the Ysengrimus, among others) and parables that were once widespread across Europe. It has also been present in proverbs since medieval times. ${ }^{11}$

The idiom occurs in 53 of the European languages considered here. ${ }^{12}$ Some informants reported variants with GAME, like Hungarian macska-egér játékot qüz vkivel 'sb. plays a cat-mouse-game with sb.' or Turkish kedi fare oyunu 'cat mouse game'. In the following, the literal translation is omitted for those idioms that mean 'to play cat and mouse with sb.': Norwegian leke katt og mus med noen, Swedish leka katt och råtta med ngn. 'to play cat and rat with sb.'13, Luxembourgish Kaz a Maus spillen mat engem, Yiddish shpiln zikh vi a kats mit a moyz 'to play as a cat with a mouse', Welsh chwarae â rhywun fel cath â llygoden 'to play with sb. like a cat with a mouse', French jouer au chat et à la souris avec qqn., Catalan jugar al gat $i$ al ratoli amb algú 'to play the cat and the mouse with sb.', Aromanian tracã, ca matsa cu shoariclu 'to play like a cat with a mouse', Latvian spēlējas kā kaķis ar peli ar kādu 'to play with sb. as the cat with the mouse', Russian играть с кем в кошки мышки, Kashubian bawic sã z kims w kòta $i$ mësz 'to play with sb. cat and mouse', Bulgarian играя си на котка и мишка с някого, Albanian luaj si macja me miun me dikë 'to play cat with the mouse with sb.', Greek

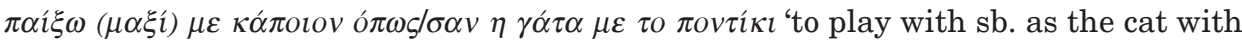
the mouse', Estonian kellegagi kassi ja hiirt mängima, Komi-Zyrian шырӧн-каньӧн ворсны кодкӧдкӧ, Mari пырыс ден коляла модаш 'to play cat-mouse', Karaim mačy byla syčan kibik ojnama 'to play as a cat with mouse', Tatar мэче белэн тычкан уены уйнау 'to play cat and mouse', Azerbaijani siçan-pişik oynamaq 'to play cat (and) mouse', Georgian k'at'a-tagvobanas tamashi 'to play cat-mouse', Maltese jilg'ћab tal-gurdien u tal-qattus 'to play cat and mouse'; Basque katu eta saguaren jolasean ibili 'to play cat and mouse'.

\section{(9) as poor as a church mouse}

'very poor, having no wealth and few possessions'

Economy or poverty is the subject of several folk tales in which the protagonist is a mouse (e.g. The Town Mouse and the Country Mouse, a motif also attri- 
buted to a fable of Aesop). The tale Cat and Mouse in Partnership (KHM No. 2) seems most closely connected to idiom (9) because it is set in a church, where cat and mouse together hide a little pot of fat under the altar for the winter but the cat eats the fat and the mouse remains "poor". It is probable that an old proverbial expression was another basis for this idiom. ${ }^{14}$

Our informants have cited two main idiom variants: with the concept Mouse and with the concept RAT. Only Icelandic has both variants: fátækur eins og kirkjurotta / kirkjumús. The areal distribution reveals some regularities: RAT can be found in the North Germanic languages, in Dutch and Breton, in the Baltic and North Finnic languages, while all Slavonic languages use the variant with MOUSE. Examples with RAT: Norwegian fattig som en kirkerotte, Dutch zo arm als een kerkrat, Breton bezañ paour evel ur razh iliz, Provençal paure coume un gàrri de glèiso, Latvian nabags kā baznīcas žurka, Lithuanian biednas kaip bažnyčios žiurkè, Estonian vaene kui kirikurott, Karelian kö̈̈hü ku kirikönrottu; examples with MOUSE: Scots a puir wee kirk moose, North Frisian so aarem ü̈̈s en müs uun a sark, Luxembourgish aarm sin wie eng Kiechemaus, Romansh pover sco ina mieur-baselgia, Romanian la fel de sărac ca un şoarece de biserică, Russian беден как церковная мышь, Slovak chudobný ako kostolná myš, Polish biedny jak mysz kościelna, Kashubian biédny jak kòscelnô mësz, Croatian siromašan kao crkveni miš, Serbian сиромашан као црквени миш, Macedonian како црковен глушец, Hungarian szegény, mint a templom egere, Moksha-Mordvin ашу кода церькунь шеер.

\section{Fabled animals}

The roots of the following widespread idioms lie in age-old semiotisations of animals that were handed down through various legends and books on natural history since ancient times. One of the most famous works is the 37 -volume Naturalis historia of Pliny the Elder (23-79 AD), a remarkable attempt to summarise all the knowledge known to the Romans at that time. The early Christian canonical compendium of animal symbolism Physiologos (ca. 200 AD), which was translated into Latin around the year 400 and subsequently into many other languages, or medieval beast epics have also contributed to the semiotisations of animals. The legendary behaviours of the phoenix, ostrich, lynx and crocodile were passed on in this way; they led to the formation of proverbial phrases and left traces in today's Lexicon of Common Figurative Units, although their origins may be lost in the mists of the distant past. Again, not only the idioms but most notably the underlying narrative motifs have been widespread since earliest times.

\section{(10) to rise like a phoenix from the ashes}

'to emerge as new from something that has been destroyed; to find renewal in destruction' 
Idiom (10) belongs to the oldest layer of common European figurative language. The phoenix was a mythical oriental bird. It was adored by the Egyptians as an incarnation of the sun god. For the Greeks (first mentioned by Hesiod, ca. $700 \mathrm{BC}$ ), it was a symbol of eternal rejuvenation and immortality. Herodotus (485-425 BC) tells the story of the phoenix as a bird that burns itself in its nest of spices every five hundred years. The myth of its rebirth and rise from the ashes to the sky was first narrated by Pliny the Elder in his Naturalis historia (10.2.3ff). The phoenix found its way into Christian allegory by means of the Physiologos and writings of early Christian poets and Church Fathers. The legend was alive in the Middle Ages when the phoenix became a symbol of resurrection in arts, painting and beast epics (cf. Öberg 2009).

Equivalents of idiom (10) exist in most of the 41 standard languages included in the WI project but only in few of the lesser-used varieties. As it belongs to a high register of language, there is no place for it in the less official languages. The idiom often appears in truncated form as "to resurrect/rise (again) from the ashes" (Dutch uit zijn as herrijzen, Slovak vystúpie z popola, Finnish nousta tuhkasta) or as a simile "like a phoenix from the ashes" (Icelandic eins og Fönix úr öskunni, Belorussian як феникс 3 пеплу, Albanian si feniksi nga). Most of the further examples can be roughly translated as 'to rise like a/the (bird) phoenix (from the ashes)': Norwegian reise seg som en (fugl) føniks (av asken), Spanish renacer de las cenizas como el Ave Fénix, Romanian a renaște ca pasărea Phoenix din propria cenuşă, Russian возникать как феникс из пепла/ возродиться из пепла как птица-феникс, Polish powstać jak Feniks z popiołów, Croatian dići se (kao feniks) iz pepela, Macedonian воскреснува како феникс од пепелта, Bulgarian възкрьсвам като феникс от пепелта; Albanian ringjallet si Feniksi, Hungarian fönixként támad fel hamvaiból, Estonian fööniksina tuhast tõusma, Azerbajani simurq quşu kimi alovdan yenidən yaranmaq, Georgian peniksivit perplidan agdgoma.

\section{(11) to hide/bury one's head in the sand}

'to pretend a problem does not exist and deliberately refuse to accept the truth about something unpleasant'

Idiom (11) goes back to the old mistaken belief that the ostrich hides its head under (one of its) wings (in other versions: in a bush, in the sand) at the first sign of danger, as if it did not want to see the danger. Although there is an observation of nature behind this myth, ${ }^{15}$ it is due to the old semiotisation of the bird. Pliny the Elder writes about the ostrich's foolish behaviour in his Naturalis historia (10.1) that the bird imagines, when it has thrust head and neck into a bush, that the whole of its body is concealed. This has later been taken up in the Physiologos (24.3: 259): "when it lays eggs it puts its head in the sand" and other natural history and literary works. ${ }^{16}$

The three ancient and medieval ideas of the ostrich's fabled behaviour - it was believed to put the head under its WINGS, into a BUSH or in the SAND - has 
left traces in the idioms of present-day languages. The WING version appears in Spanish meter/esconder la cabeza bajo el ala/debajo del ala 'to put the head under/below the wing' and Catalan amagar el cap sota l'ala 'to hide the head under the wings', while the BusH version is still present in the Finnish idiom panna päänsä pensaseen 'to put one's head into the bush', with the same figurative meaning (probably supported by the alliteration, so common in Finnish phraseology). In most languages, however, there is a version with SAND.

The following idioms can be roughly translated as 'to stick/put/thrust the/one's head in the sand': Icelandic stinga höfðinu i sandinn, West Frisian de kop yn it sân stekke, Luxembourgish de Kapp an de Sand stiechen, Romansh chatschar il chau en il sablun, Czech strkat hlavu do písku, Sorbian hłowu do pěska tyknyćltykać (kaž štrus), Croatian zabiti glavu u pijesak (kao noj), Serbian главу у песак, Bulgarian завирам глава в пясъка, Hungarian homokba dugja a fejét. The next idioms mean approximately 'to hide the/one's head in the sand': Norwegian gjemme hodet $i$ sanden, Latvian pasleppt galvu smiltīs, Russian прятать голову в песок, Polish chować głowę w piasek, Estonian pead liviva alla/sisse peitma, Moksha Mordvin (страус лаца) шувар алу пря кяшендемс, Basque (ostrukak bezala) nork bere burua lurpean ezkutatu. Some idioms roughly mean 'to bury the/one's head in/under the sand': Welsh claddu pen yn y tywod, Italian nascondere la testa sotto la sabbia, Galician enterrar a cabeza na area, Portuguese esconder a cabeça na areia (como a avestruz), Romanian a-şi îngropa capul în nisip, Lithuanian galvą i smèlị kišti, Turkish başını kuma gömmek.

\section{(12) to be lynx-eyed}

'to have extremely sharp, penetrating eyes, good powers of vision'

Idiom (12) cannot be interpreted on the basis of today's knowledge about the lynx. The animal's eyes are not sharper than those of other animals of the Felidae family. The legend of the sharp-eyed lynx came into being due to a number of historical "accidents". In Greek mythology, good powers of vision were ascribed to Lynkeus, one of the Argonauts. It is recorded in Horace's I. Epistle (1.28) that he was so sharp-sighted, that he could see through the earth and distinguish objects that were miles away. Lynkeus' name has been connected with the similarly sounding Greek word $\lambda \hat{v} \gamma \xi$ 'lynx'. Again, this semiotisation of the lynx was spread as "scientific" knowledge by various writers: Pliny called the lynx "the most clear sighted of all quadrupeds" (Naturalis historia 8.28) while Plutarch and other scholars added the idea that the lynx can penetrate through trees and rocks with its sharp sight. Konrad von Megenberg praises the lynx's acuity of vision and hearing in his influential Das Buch der Natur (ca. 1350). Christian medieval symbolism connected the lynx with "vigilance, watchful alertness". This symbolic knowledge has almost completely been lost in the course of the following centuries but survived in figurative units like idiom (12). 
Equivalents of the idiom show different structures like "to have (the) eyes of a lynx" (French avoir des yeux de lynx, Italian avere gli occhi di lince, Spanish tener los ojos de lince), 'to have lynx-eyes' (German Luchsaugen haben, Dutch lynxogen hebben) or similes (e.g. German Augen haben wie ein Luchs, Slovak mat' oči ako rys, both literally 'to have eyes like a lynx', Czech vidět jako rys 'to see like a lynx'), all meaning figuratively 'to have extremely sharp eyes, good powers of vision'. The old semiotisation of LYNX can be found in one-word metaphor, in the sense of 'a person with good powers of vision, a watchful, clever person', and in idioms like German aufpassen wie ein Luchs 'to watch like a lynx', meaning figuratively 'to be very attentive and vigilant' (cf. Dobrovol'skij \& Piirainen 2005: 272, 281f).

\section{(13) to weep/shed crocodile tears}

'to show false or pretended sadness, to display insincere grief; to pretend that one is weeping'

According to ancient legends, crocodiles weep pitifully like a child and shed insincere tears of sorrow in order to lure their victims and when devouring them. There is a physiological background to this: crocodiles make a moaning sound and, after eating, shed excess salt from glands located just beneath the eyes, giving the impression of tears. These legends of crocodiles are believed to be of classical origin. Pliny the Elder and Seneca both give rather fantastic accounts of the crocodile's wiles. The legends were later expanded as "scientific" knowledge across Europe from the Middle Ages onwards (at a time when crusaders became acquainted with real crocodiles for the first time) and the crocodile became the symbol of feigned friendship. In his Das Buch der Natur (ca. 1350), Konrad von Megenberg describes the crocodiles' behaviour "when it kills a person, it weeps over him" (wenn ez aines menschen ertoett, sô waint ez in). The legend appears also in the famous Book of Travels (ca. 1356) attributed to Sir John Mandeville. The proverbial phrase was spread across the European languages by the humanists, by Erasmus, and other influential authors. ${ }^{17}$

For the full data see Appendix 3. As our research has shown, equivalents of the idiom are extremely widespread. They are known in at least 55 European languages and also in various non-European languages, with nearly the same lexical and semantic structure. The majority of these languages primarily use the nominal phrase "crocodile tears", meaning 'an insincere display of grief, hypocritical sorrow'. While all the standard languages and various smaller languages analysed show quite a consistent picture, only some of the minor languages go their own way. With respect to this very wide dissemination of the idiom, several aspects seem to come together here. The idiom goes back to legends passed on from antiquity, on the one hand, and via other Asian narrative traditions, on the other, into various cultural areas of Europe, Asia and North Africa. However, there has not been any research on the route that the idiom equivalents have taken to get into the individual contemporary languages, whether it was through old traditional legends once well-known in the Indian, Arabic and European areas or based on a more recent layer of borrowing. 

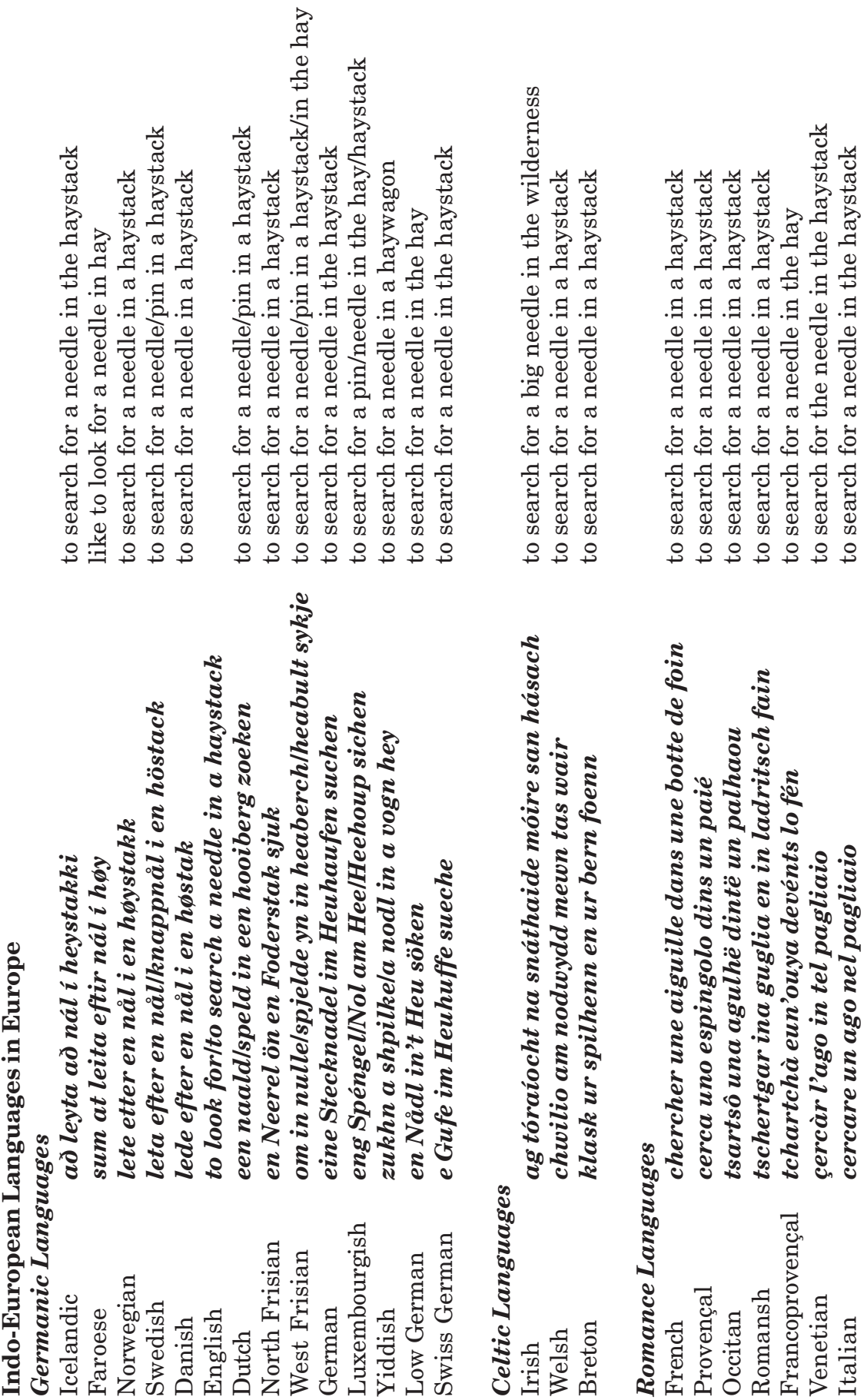


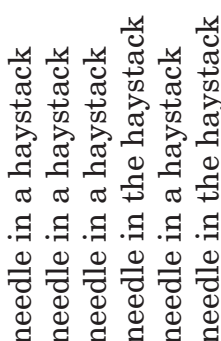
$\pi \quad \sigma \quad \sigma \quad \pi \quad \pi \quad \pi$

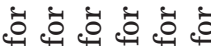

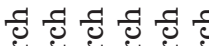

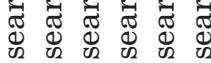
아요요요요요 우
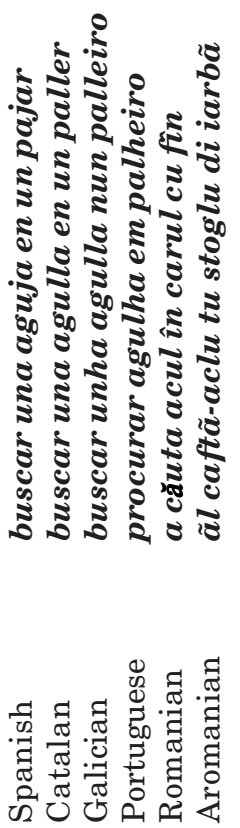
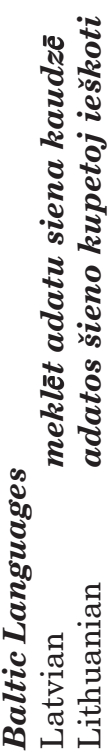

$\frac{n}{4}$

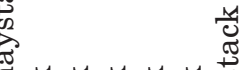
व

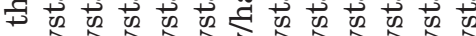

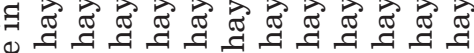

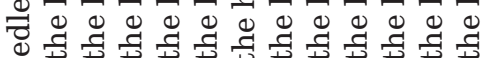

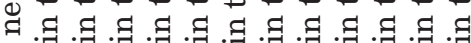

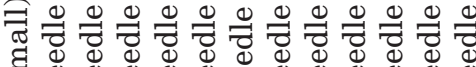
Q

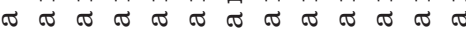

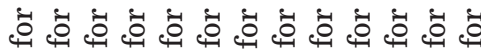

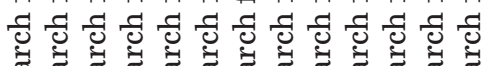

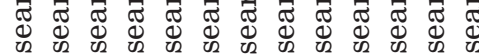

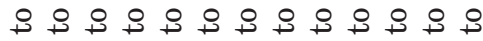

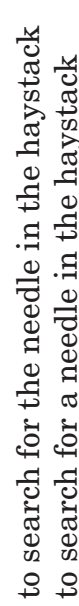

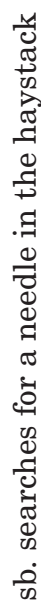

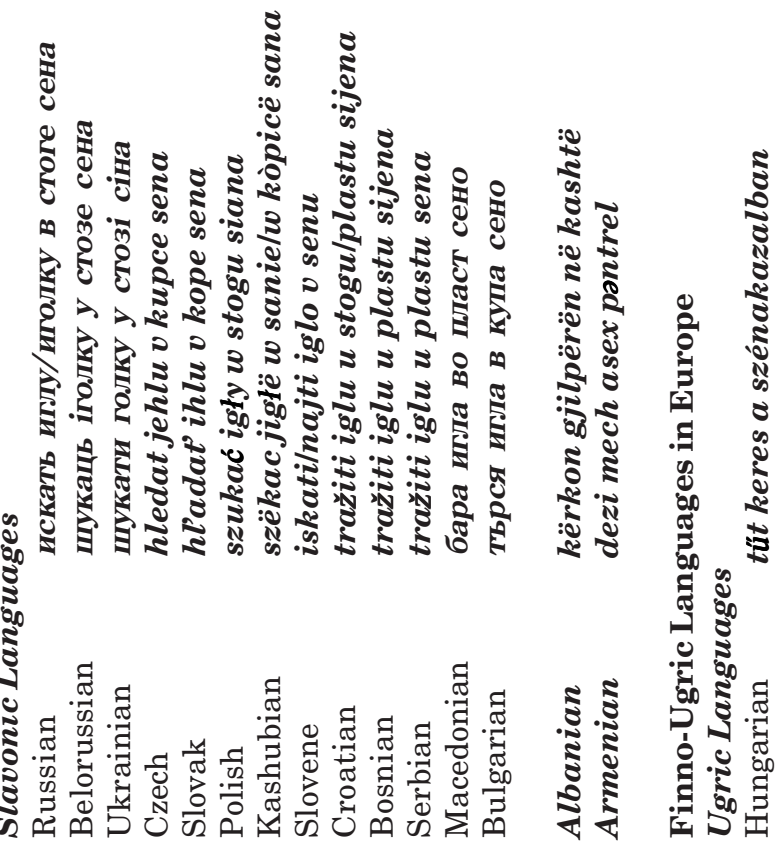



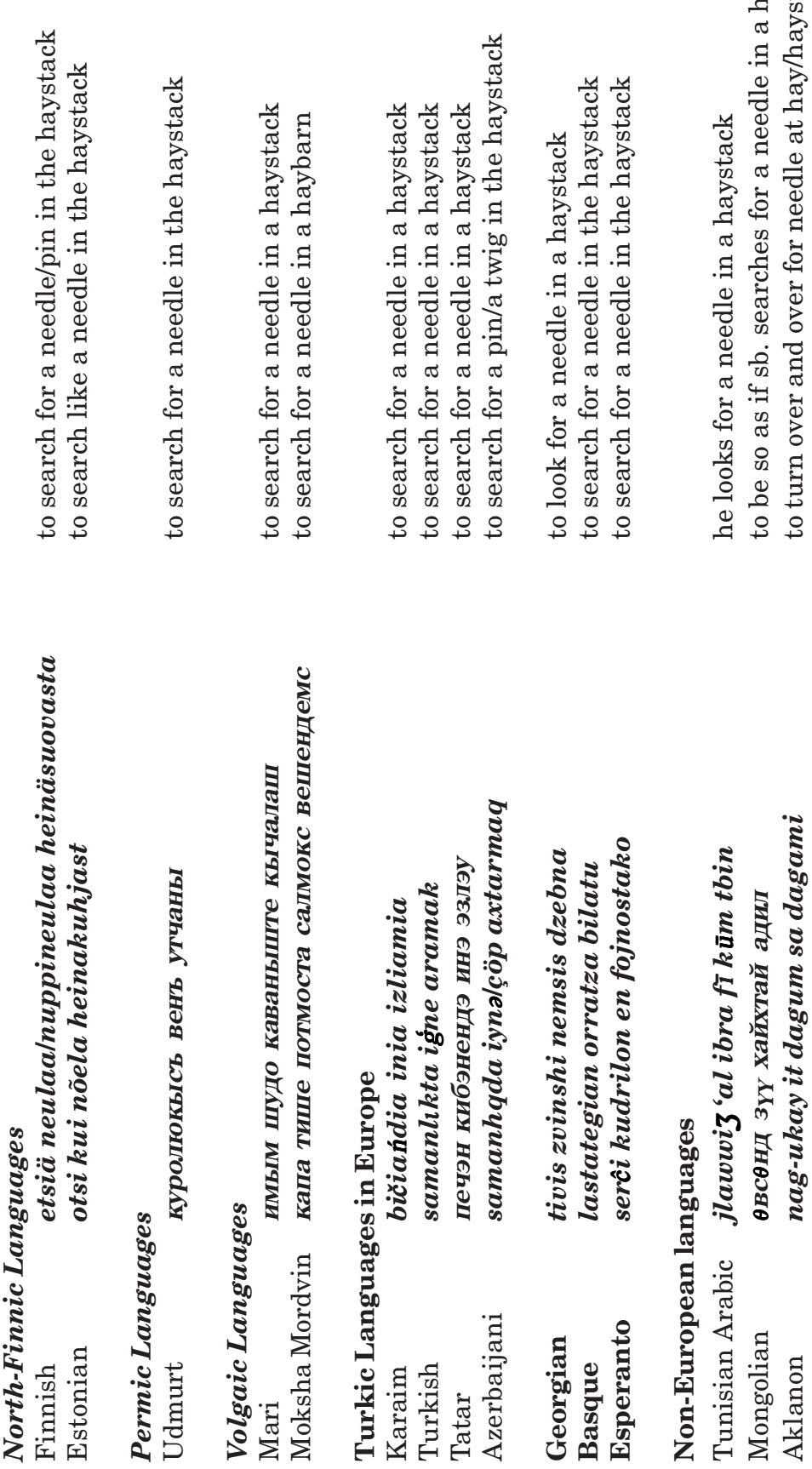

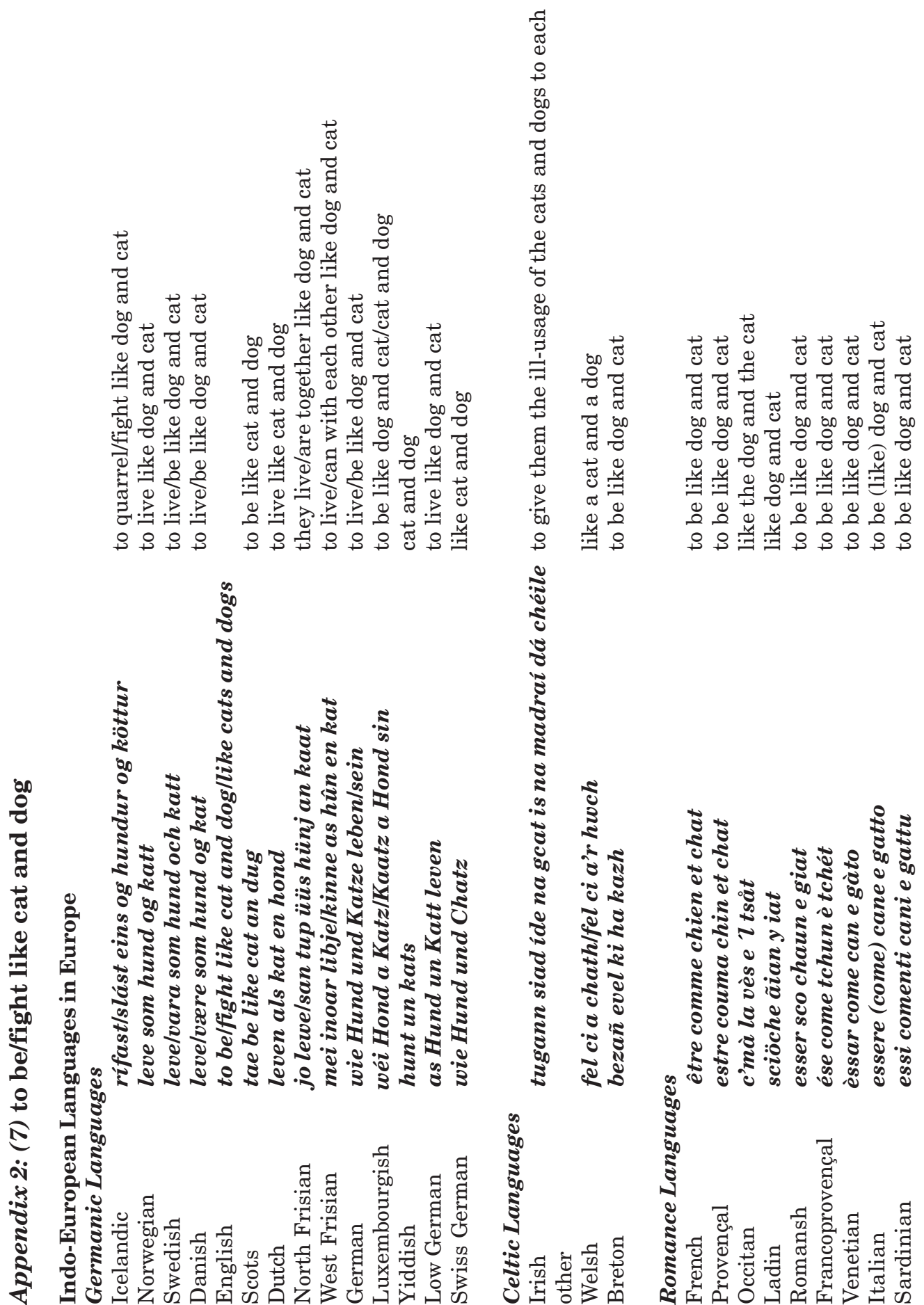

$\frac{\pi}{2}$

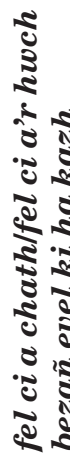
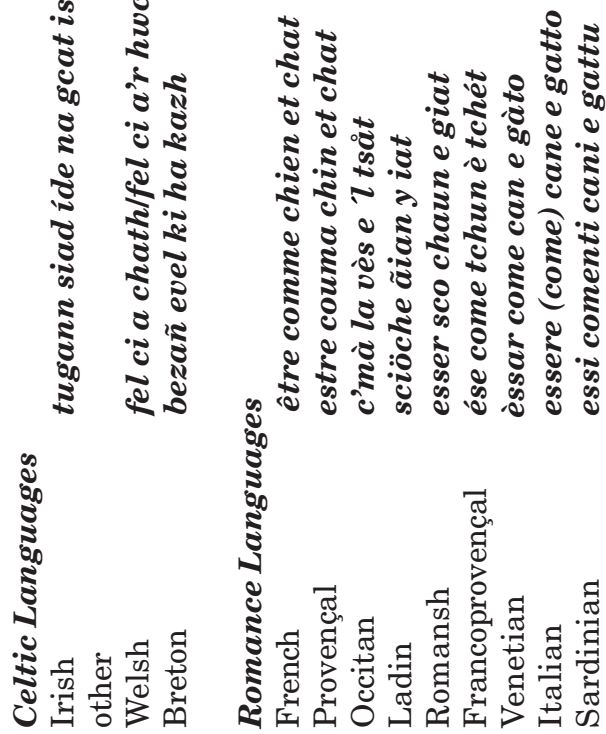

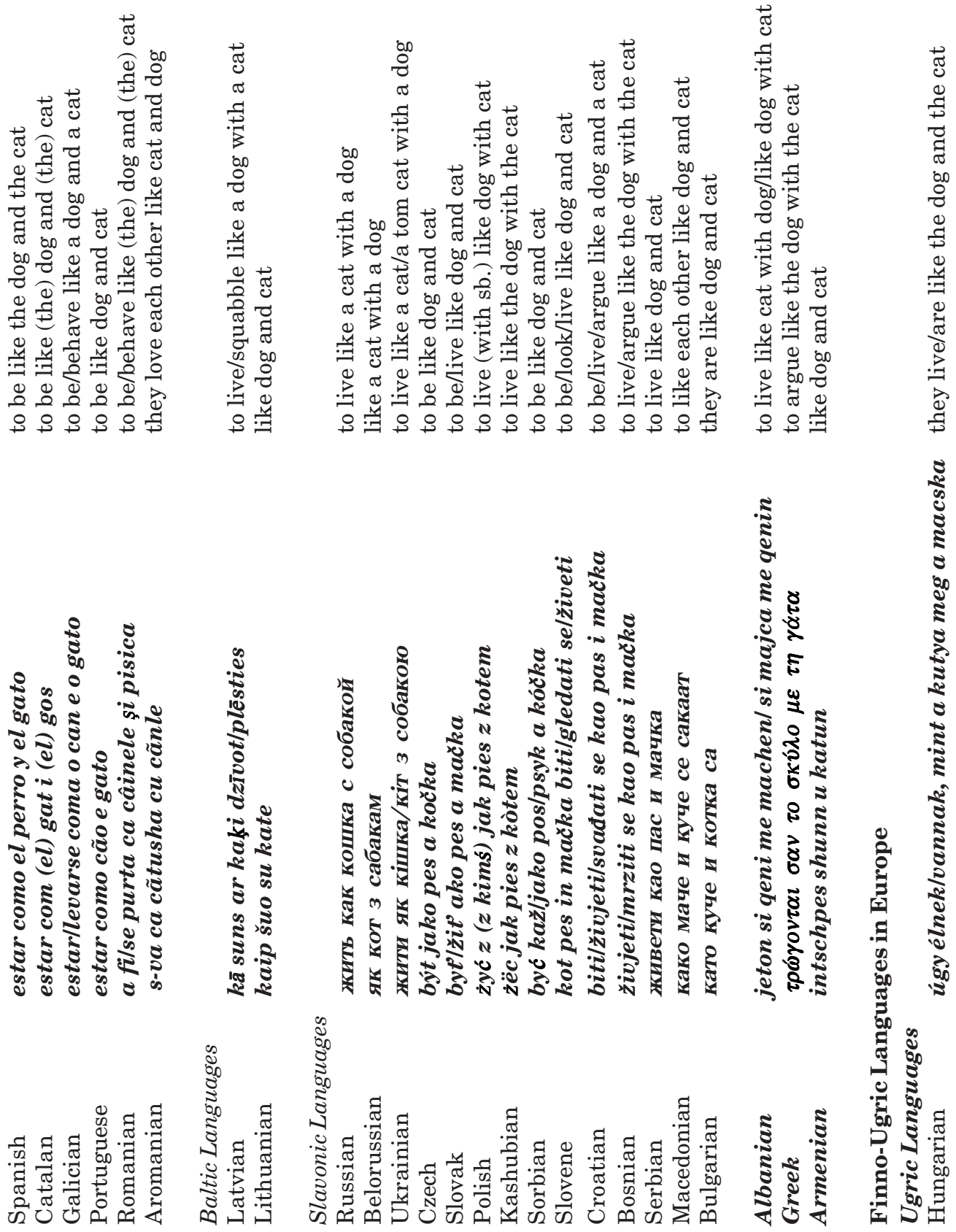

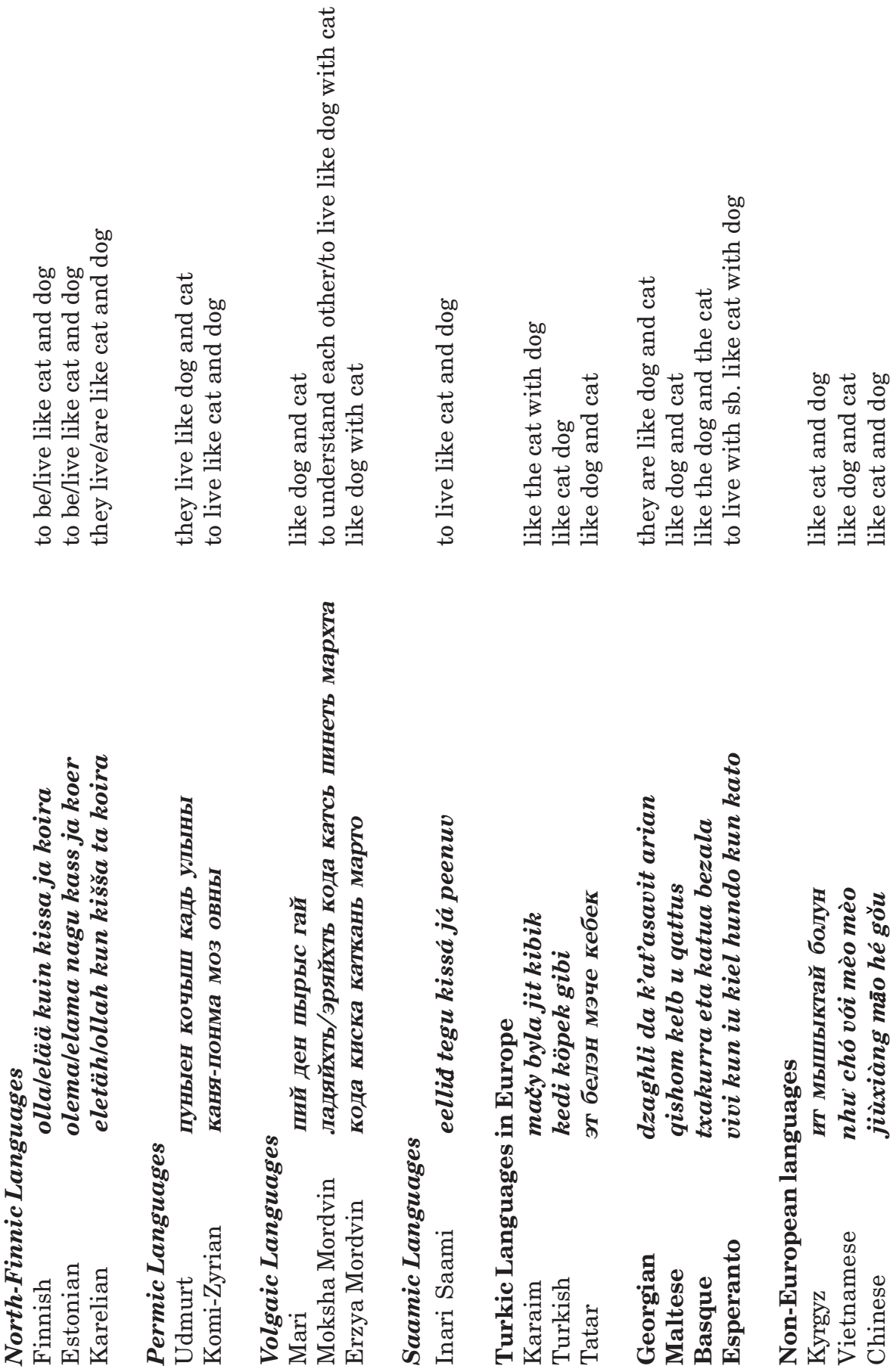

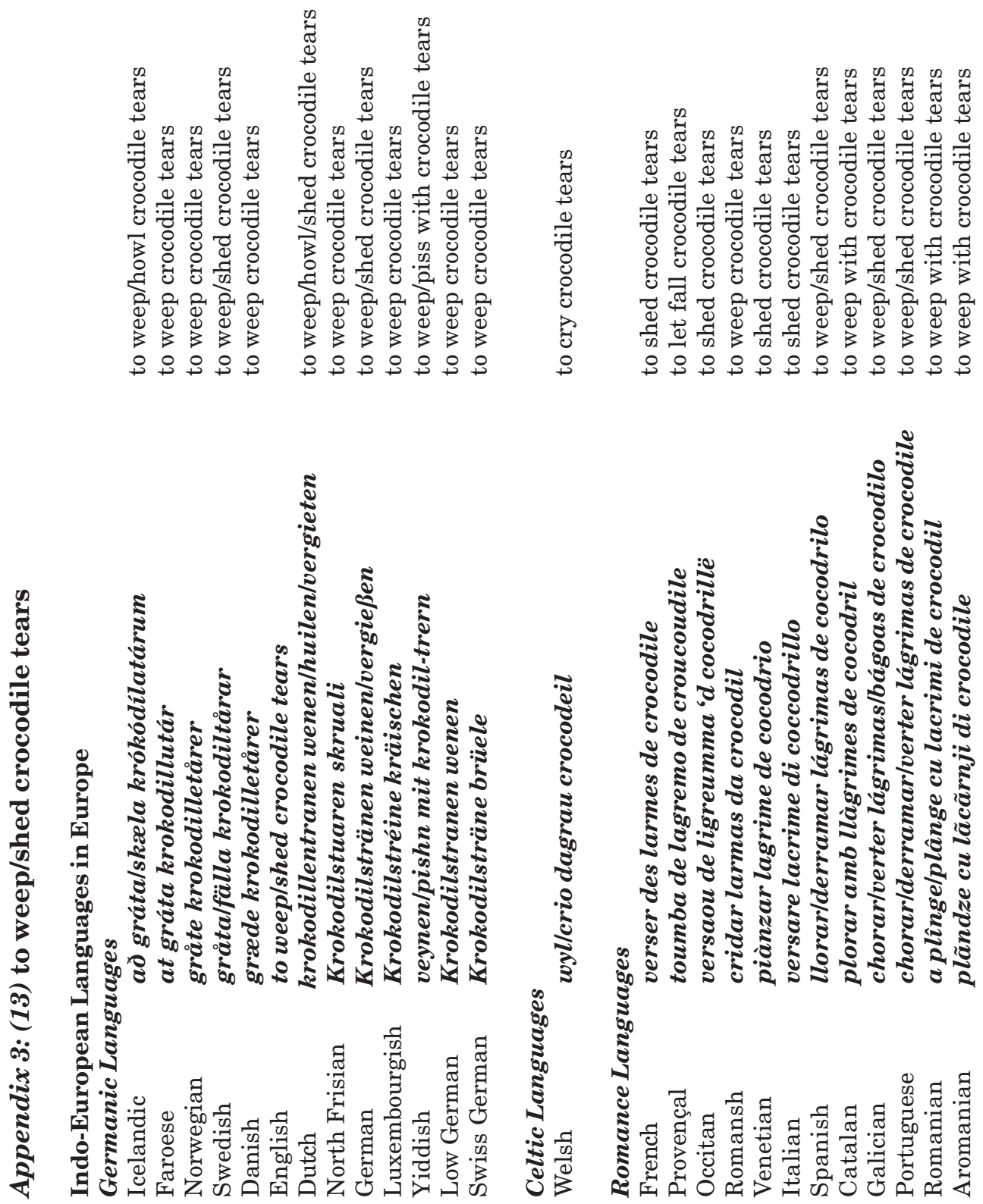

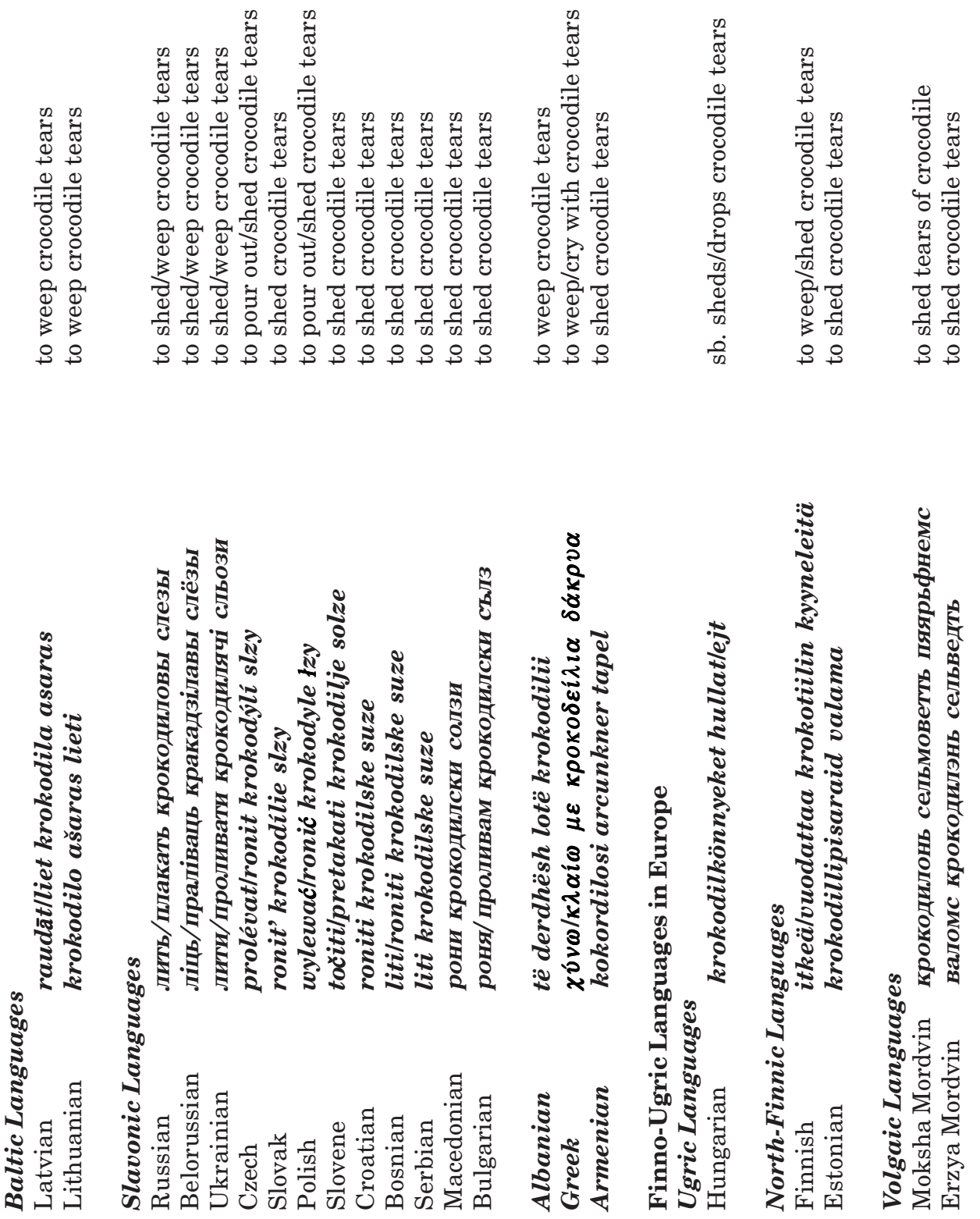

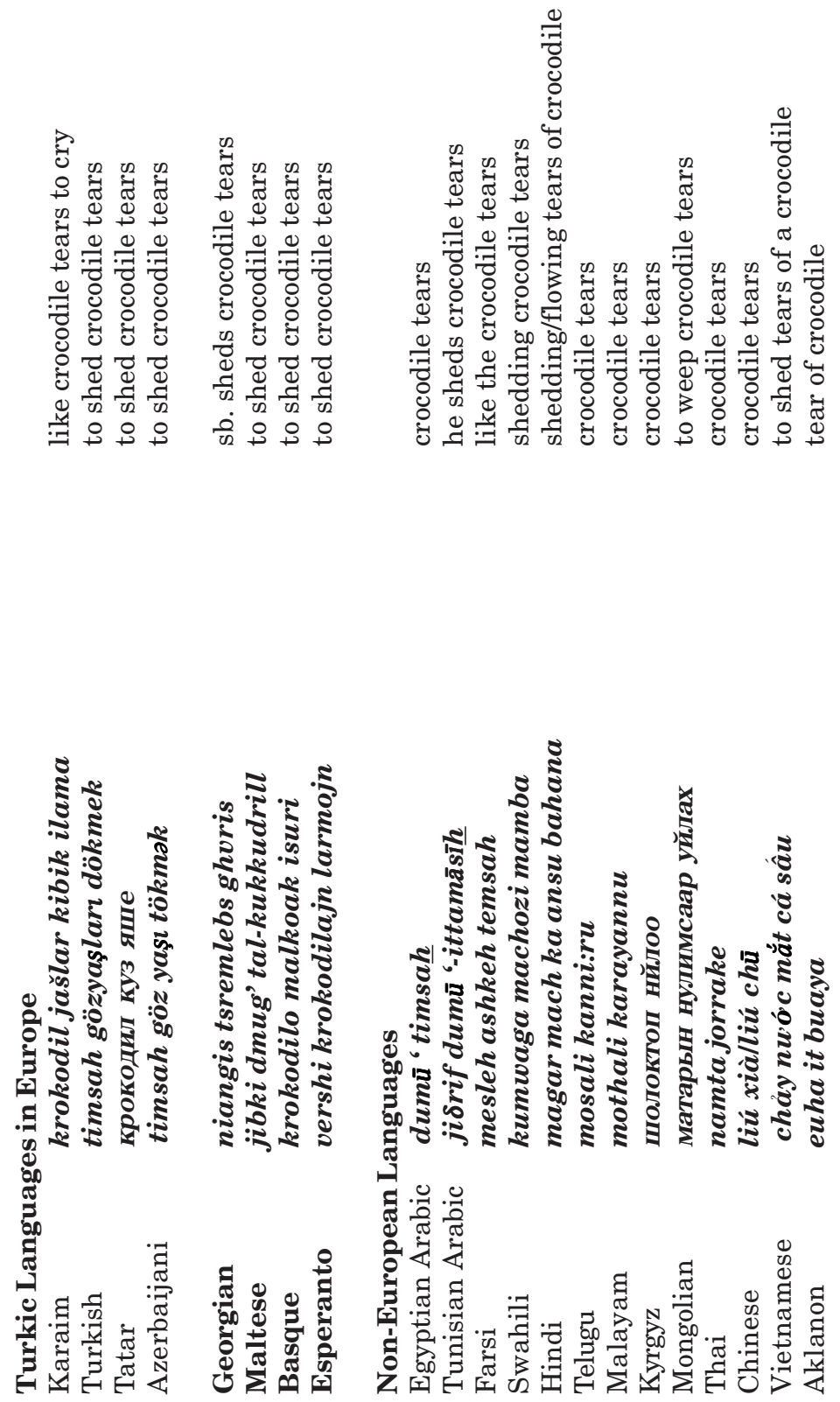


\section{NOTES}

${ }^{1}$ Minor languages like Erzya, Karelian, Komi, Mari, Moksha, Udmurt, Veps and Inari Saami are included in the project, thanks to the great support by Anneli Baran and Terje Keldola from Tartu and Anna Idström from Helsinki with mediating experts.

2 The focus is not so much on "European" because many WIs exist also in non-European languages; cf. also Paczolay 1997.

3 In his Adagia (1.4.32) Erasmus of Rotterdam already suspected that Caesar had reverted to a common proverbial phrase, the correct version of which is alea iacta esto! 'The dice is to be thrown'.

4 There is a number of Greek and Latin proverbs affiliated to this motif (Hansen 2002: 71f; Uther 2004: No. 801, 1180), which found their way into the famous proverb collections (cf. Erasmus' Adagia 1.4.60: cribro aquam haurire) and also came into the vernaculars in this way (cf. AT 1180; TPMA 10, 339f and 12, 137).

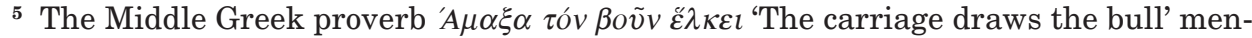
tioned in Diogenianos' Pantodapé lexis (3.30) can be identified in other authors' works, e.g. in Erasmus' Adagia (1.7.28), and in Egbert's Fecunda Ratis (1.317): Ante boues uersum non uidi currere plaustrum 'I did not see running any cart turned before the oxen' (cf. AT 1249; Jones 1989: 201-203; Hansen 2002: 72f; TPMA 9, 334f and 12,312 ).

6 According to Uther (2004 No. 1240) this tale motif goes back to Oriental (IndicArabic) literary sources. See also AT 1240; EM 1, $912 \mathrm{ff}$.

7 See AT 1586, 1586A; Uther 2004 No. 1585; EM 4, 1284ff for more detail.

${ }^{8}$ Comparable ideas are handed down via an Estonian proverb Mine'nd sääske suuretükiga laskma 'Just go and fire with a cannon at a mosquito' and by idioms such as Kashubian wëbrac sã ze seczer na mùchë 'to go with the axe against the fly', Albanian e vret mizën me sëpatë 'to kill the fly with the hatchet' and Bulgarian убивам муха с парен чук 'to kill a fly with a steam hammer'. There is also a Chinese equivalent: $d \grave{a}$ pào dă má què 'to shoot with a cannon at a sparrow'.

9 See also AT 1685; EM 9, $1137 f f$.

${ }^{10}$ See Wesselski 1928: 13-17; Röhrich 1960: 259; AT 200; EM 7, 1104 for more detail.

${ }^{11}$ Cf. Röhrich 1960: 258; TPMA 6, 451; EM 7, 1104f; Moser Karagiannis 2009.

${ }^{12}$ Compare also Tunisian Arabic lu'batu-lqitti wa-lfa'ri 'the game of the cat and the mouse', Vietnamese chò i trò mèo vò̀n chuột 'to play the game cat-jump around-mouse', Mongolian муур хулгана болох 'to play cat and mouse', Aklanon hampang it kuring ag eanggam 'to play of cat - mouse/rat'.

${ }^{13}$ In Swedish idioms the word råtta 'rat' often occurs where other languages use the word meaning 'mouse'; cf. Blume 2001, see also idiom (9).

${ }^{14}$ See AT 112 and Uther 2004 No. 112 for details.

${ }^{15}$ When the ostrich hen senses danger while it is sitting on the eggs, she will stretch her long neck towards the ground to better blend into the surroundings. 
16 The allusion to the fabled bird can also be identified in the Medieval Latin proverb collection Fecunda Ratis (1, 737).

${ }^{17}$ See Schöne 1993: 73-76; EM 8, 487.

\section{REFERENCES}

Adagia $=$ Collected Works of Erasmus, Vols. 31-36. 1982-2006. Transl. by M. Mann Phillips. Toronto: Toronto University Press.

AT = Aarne, Antti \& Thompson, Stith 1961. The Types of the Folktale. A Classification and Bibliography. Helsinki: Suomalainen Tiedeakatemia.

Blume, Herbert 2001. Katt och råtta, Katz und Maus. Ungleiche lexikalisch-semantische Strukturen im Schwedischen und Deutschen. In: A. Burkhardt \& D. Cherubim (eds.) Sprache im Leben der Zeit: Beiträge zur Theorie, Analyse und Kritik der deutschen Sprache in Vergangenheit und Gegenwart: Helmut Henne zum 65. Geburtstag. Tübingen: Max Niemeyer, pp. 389-399.

Carnes, Pack (ed.) 1988. Proverbia in Fabula: Essays on the Relationship of the Fable and the Proverb. Bern: Peter Lang.

Carnes, Pack 1991. The fable and the proverb: intertexts and reception. Proverbium. Yearbook of International Proverb Scholarship, Vol. 8, pp. 55-76.

Dobrovol'skij, Dmitrij \& Piirainen, Elisabeth 2005. Figurative Language: Cross-cultural and Cross-linguistic Perspectives. Current Research in the Semantics/Pragmatics Interface Vol. 13. Amsterdam: Elsevier.

$\mathrm{EM}=$ Enzyklopädie des Märchens. Handwörterbuch zur historischen und vergleichenden Erzählforschung 2010. Vol. 13. Berlin: de Gruyter.

Fecunda Ratis = Voigt, Ernst 1889. Egberts von Lüttich Fecunda Ratis. Zum ersten Mal Herausgegeben aufihre Quellen zurückgeführt und erklärt von Ernst Voigt. Halle a. S.: Verlag von Max Niemeyer.

Grzybek, Peter 1989. Invariant Meaning Structures in Texts - Proverb and Fable. In: K. Eimermacher \& P. Grzybek \& G. Witte (eds.) Issues in Slavic Literary and Cultural Theory. Studien zur Literatur- und Kulturtheorie in Osteuropa. Bochum: Brockmeyer, pp. 349-389.

Hansen, William F. 2002. Ariadne's Thread: A Guide to International Tales Found in Classical Literature. Ithaca, NY: Cornell University Press.

Jones, Malcolm 1989. Folklore Motifs in Late Medieval Art I: Proverbial Follies and Impossibilities. Folklore, Vol. 100, No. 2, pp. 201-217.

$\mathrm{KHM}=$ Kinder- und Hausmärchen gesammelt durch die Brüder Grimm. Hrsg. von Friedrich von der Leyen. Die Märchen der Weltliteratur. Jena: Diederichs Verlag.

Mieder, Wolfgang 1986. Sprichwörtliche Schwundstufe des Märchens. Proverbium. Yearbook of International Proverb Scholarship, Vol. 3, pp. 257-271.

Mieder, Wolfgang 2010. "Luftschlösser bauen". Traditionelle und innovative Funktion eines redensartlichen Wunschbildes. In: W. Mieder (ed.) "Spruchschlösser (ab)bauen": Sprichwörter, Antisprichwörter und Lehnsprichwörter in Literatur und Medien. Wien: Praesens, pp. 341-362. 
Moser Karagiannis, Emmanuelle 2009. 'Jouer au chat et à la souris'. Etude lexicographique comparée. In: K. Glykioti \& D. Kinne (eds.) Griechisch - Ellinika Grekiska: Festschrift für Hans Ruge. Frankfurt am Main \& New York \& Oxford: Peter Lang, pp. 171-177.

Naturalis historia = Pliny the Elder 1991. Naturalis historia / Naturkunde in 37 Bänden . Lateinisch - Deutsch. München: Artemis und Winkler.

Öberg, Jan 2009. Der Vogel Phönix und Albertus Pictor - ein Fabeltier des archaischen Griechenlands im spätmittelalterlichen Schweden. In: K. Glykioti \& D. Kinne (eds.) Griechisch-Ellinika-Grekiska: Festschrift für Hans Ruge. Frankfurt am Main \& New York \& Oxford: Peter Lang, pp. 179-177.

Paczolay, Gyula 1997. European Proverbs in 55 Languages with Equivalents in Arabic, Persian, Sanskrit, Chinese and Japanese. Veszprém: Veszprémi Nyomda.

Permiakov, Grigorii L. 1979. From Proverb to Folk-tale: Notes on the General Theory of Cliché. Moscow: Nauka.

Perry, Ben Edwin 1959. Fable. Studium Generale, Vol. 12, pp. 17-37.

Physiologos = Sbordone, Francesco (ed.) 1976 [1936]. Physiologus. Nachdruck der Ausgabe Rom. Hildesheim: Olms Verlag.

Piirainen, Elisabeth 2009. Phraseologie aus eurolinguistischer Perspektive: Aufgaben, Methoden, Ergebnisse. Neuphilologische Mitteilungen. Bulletin de la Société Néophilologique, Vol. 60, No. 4, pp. 451-486.

Piirainen, Elisabeth 2010. Common features in the phraseology of European languages: cultural and areal perspectives. In: J. Korhonen et al. (eds.) Phraseologie global - areal - regional. Akten der Konferenz EUROPHRAS 2008 vom 13.-16.8.2008 in Helsinki. Tübingen: Gunter Narr, pp. 15-27.

Piirainen, Elisabeth (forthcoming). Widespread Idioms in Europe and Beyond. Toward a Lexicon of Common Figurative Units. International Folkloristics. New York: Peter Lang.

Röhrich, Lutz 1960. Sprichwörtliche Redensarten aus Volkserzählungen. In: K. Bischoff \& L. Röhrich (eds.) Volk, Sprache, Dichtung. Festgabe für Kurt Wagner. Gießen: Wilhelm Schmitz, pp. 247-275.

Schöne, Albrecht 1993. Emblematik und Drama im Zeitalter des Barock. München: C. H. Beck.

Spalding, Keith 1959-2003. An Historical Dictionary of German Figurative Usage. Oxford: Basil Blackwell.

TPMA = Thesaurus Proverbiorum Medii Aevi: Lexikon der Sprichwörter des romanisch germanischen Mittelalters 1995-2002. Berlin \& New York: De Gruyter.

Trokhimenko, Olga V. 1999. “Wie ein Elefant im Porzellanladen”: Zur Weltgeschichte einer Redensart. Burlington, Vermont: The University of Vermont.

Uther, Hans-Jörg 2004. The Types of International Folktales. A Classification and Bibliography, Based on the System of Antti Aarne and Stith Thompson. Editorial staff: Sabine Dinslage, Sigrid Fährmann, Christine Goldberg, Gudrun Schwibbe. 1: Animal Tales, Tales of Magic, Religious Tales, and Realistic Tales, with an Introduction. (FF Communications 284). Helsinki: Suomalainen Tiedeakatemia. Wesselski, Albert 1928. Erlesenes. Prague: Gesellschaft deutscher Bücherfreunde in Böhmen. 


\title{
IMAGES OF BIRDS IN MORDVINIAN MYTHOLOGY
}

\author{
Tatiana Deviatkina
}

\begin{abstract}
The article focuses on various functions of birds appearing as an indispensable element of the mythological system. First of all, their role is underlined in the cosmogonic and anthropogonic act. The most archaic is the image of the Great Bird, the creator of the world and man (among MordviniansErzians). Mention is made about the role of prophetic birds and their use in the capacity of sacrifice and rituals. Gods and deities presented themselves in images of different birds (duck, eagle, pigeon, swan, swallows etc.). Some comparisons with other Finno-Ugric ethnoses (Mari, Komi etc.) are given.
\end{abstract}

Key words: anthropogony, birds, cosmogony, gods and deities in the image of birds, Mordvinians (Mokshans and Erzians), mythology, prophetic birds, sacrifice

Images of birds occupy a particular place in the mythology of Mordvinians, and among other peoples. However, the subject matter presented in the article has so far not received the due attention of researchers. Birds appear as an indispensable element of the mythological system and perform different functions. First of all, it is essential to describe their cosmogonic and anthropogonic functions.

The image of the Great Bird (mdM Ine Narmon', mdE Ine Narmun') is the most archaic in Mordvinian mythology where she acts as the creator of the world. Thus, she lays the Great World Egg (mdE Ine Al, mdM Otsiu Al), from which the world appears. The Earth comes from the egg-yolk, while the sky and the underground solidity emerge from the eggshell.

A similar motif, the creation of the world from an egg laid by a bird, is typical in the cosmogony of other Finno-Ugric peoples: Finns, Estonians, Saami, Komi (Myths 1994: 564). Likewise, in Mordvinian mythology, the Great Bird is the original mother of some ethnoses and deities. According to a Mordvinian myth, the forefathers of Erzians-Mordvinians, Russians and Chuvashs were born from the three eggs of the Great Bird. Similarly, deities-patronesses of fertility - Norovava (mdE), wind - Varmava (mdM, mdE), woods - Vir'ava (mdM, mdE) were hatched out of three eggs laid by Ine Narmun' (mdE) in the nest on 
an unusual birch (Harva 1952: 141) which grew in the centre of the Earth. Three branches of the birch formed the tree-top, and three forks - its root. The birch was found by the Great Bird (God's messenger) - Ine Narmon' (mdM), who built a nest in the tree-top, laid three eggs, hatched them, and out came the three sisters-deities.

The image of a duck (mdM iaksiarga, mdE iaksiargo) is no less popular in the world creation's myths. According to preserved Mordvinian materials, she is notable for her unusual beauty, her physical description is full of mythological symbols: she has gilded legs; a coin-like patterned design appears on her wings, which have golden edges; her feathering resembles coins; there are tsar's signets (divine signs) on her back; her head is silvery; her beak and feet are made of copper; her wings are crescent-shaped (UPTMN 1963: 159). She radiates unusual light, being majestic and sublime. According to myths, once a God (it is unknown whether the Mokshan or Erzian one) swam in the ocean in the shape of a duck. At first, there was water everywhere, and the God had dived to the bottom of the ocean, taken a lump of earth in his beak, spat it out (UPTMN 1983: 188), and the latter began to grow and increase. Thus the Earth was created.

At the request of the Supreme God of Mokshas-Mordvinians the same image of a duck is assumed by deuce Shaitan (mdM), with the task of diving deepdown to the bottom of the sea in order to get construction material (soil, sand) for creating the Earth. This myth undoubtedly belongs to the apocryphal type. The mythological plots of the Erzians of the Samara province tell that Shaitan was born by Chipaz - the Supreme God of the Sun - the devil came out from the Chipaz' spit produced in vexation and his stroke with the staff (Pecherskii 1986: 45). The Moksha-Mordvinian Supreme God (Shkai) gives soul to Shaitan. However, he could not breathe it into Shaitan and instead puts the soul on his face. Then the God (Shkai) moves this soul into a duck and let her swim in the Great Ocean which surrounded the whole Earth. Shaitan agrees to help Chipaz to create the world out of the sand that he had brought up (after changing into a duck) (Pecherskii 1986: 53) from the bottom of the sea. However, the devil does not follow precisely Chipaz's directions (because of his pride), and the God curses him and sends him to hell under the bottom of the sea (Pecherskii 1986: 47).

In other Finno-Ugric myths, the God-Demiurg (En - in Komi; Kugu - in Mari, Inmar - Udmurt, Numi-Torum - among the Ob-Ugrians) orders an aquatic bird or his junior brother appearing like a bird (Omol' - Komi, Keremet - Mari and Udmurt, Kul'-otyr - Mansi), who swam in the primeval ocean to get a lump of earth from the depths. From this lump of earth the God creates the Earth and all that is useful on it, while his brother (in the Mordvinian case the devil) creates mountains and all that is harmful, from the sand concealed in his mouth (Myths 1994: 564). 
The Mordvinian mythological duck image is also associated with people - the duck is imagined as a human being (a young girl), who assumed the appearance of the bird as a result of sorcery. Hence, the duck is not allowed to be hunted: the one who kills it and thus violates the ban of the kin, commits a grave crime. In folklore, the duck is usually an adopted or an unloved daughter cursed by her stepmother. She has to assume the bird-like outline until getting married. The cycle of songs devoted to a duck and a hunter reflects the people's attitude to their kindred totems. The murderers of ducks are condemned in myths and the perpetrators of the crime are punished morally and physically. In some mythical songs, a young hunter does not kill the duck at her plea for mercy, but marries her instead. In other myths, a hunter (a married man) kills the duck, without paying attention to her request, and does this in spite of the fact that she warns him of many misfortunes (his family will perish, he will lose his crops), because she is not a duck, but a messenger of the Erzian Supreme God (Verepaz) (UPTMN 1963: 159). Sometimes the duck is considered to be the bird of the deity of woods, Forest Mother (Vir'ava). In myths, the duck is a donor of life in the first place, and a bird in the second. When a hunter kills this duck, he is struck by her moaning, the quantity of her blood and feather. In myths, the duck's actions are mainly connected with water, earth, air and sky. However, the mythoepic image of the duck, brooding eggs in its nest, is not only intrinsically Mordvinian, but also common among the Finnic peoples.

In Khanty mythology, according to one version of the Earth' origin, the latter was raised during the Deluge, as a red-cropped toadstool, by the bird Luli, species-wise a small lake loon (Mythology 2000: 163).

Gods and deities could appear in the shape of different birds, underlying their supernatural knowledge. The Moksha-Mordvinian Supreme God Shkai could change into a duck, an eagle and plunge in the heart of the Earth as a worm lest it would be tracked. The son of the Erzia-Mordvinian Supreme God, Nishkepaz, could turn into a pigeon, a swan, an eagle, a swallow etc., (Deviatkina 2002: 122) whereas his favourite bird is the swan (UPTMN 1963: 47) - god's messenger and the organiser of divine and human relations. In other myths, a hawk was the messenger of Nishkepaz, the son of the Supreme God of the Sun, with people.

The goddess-patroness of marriage, health, fertility, children, women in childbirth and infants, was Ange Patiai. She descended to the Earth in the aspect of a big bird with a long golden tail. At that moment grains fell onto the fields and meadows from her golden beak. The goddess could also assume the appearance of a snow-white dove, and from above she threw flowers for bees to gather honey, and bread-crumbs for hens (Pecherskii 1986: 82). In the calendar 
and ritual poetry, the Moksha-Mordvinian deity-patroness of fields (Paks'ava) is depicted as a grouse or a woman with long drooping hair; the deity-patroness of grain - Serava (mdM sera - 'grain', ava - 'woman, mother') - and the Erzian deity-patroness of fields, Norovava - were both depicted as skylarks. In Mordvinian tradition, in springtime, usually before ploughing, people baked small birds from pastry, called "skylarks", took them to the street (children did that) and cried: "Dear little skylarks, come and bring warm air!" In some villages, this tradition has survived until today.

There are also other birds dealt with in folklore: a prophetic raven with an iron beak and three swallows were helpers of the mythological hero Tiushtia (literally: a star). In addition, he himself could change into a swallow and rooster. The Khanty mythic hero Al'vali (the seventh son of the god Torum, an intermediary between gods and people) was sometimes depicted as a goose ((Mythology 2000: 106). The Mordvinian mythological character Varda (Deviatkina 2007: 109) could make birds work. In fairy-tales, the whereabouts of "living" water is known to those who could change into a bird and get to the place unreachable to common people.

Birds were also sacrificed at various magical ceremonies. The choice of the bird for sacrifice depended on the type of the ritual, however, hens were sacrificed more frequently. For example, nine hens were killed for the traditional feast Bab'ia kasha or Baban' kasha (literally: elderly women's porridge); in honour of the deity-patroness of harvest and farming (Norowawa) a yellow bird was sacrificed, and a black hen (UPTMN 1981, Ch. 3: 190-191) was sacrificed to Mastorava, the Mother of the Earth, during the ritual in her honour; at a house-warming party a black hen was thrown into the cellar for Kudava, the deity-patroness of the home, for propitiatory purposes. Hens were also sacrificed while laying the foundation of a church or town (after cutting a hen into four parts, people put each piece in the corners of the to-be-constructed building).

A special traditional village holiday - Saraz Ozks (mdM, mdE saraz - 'hen', ozks - 'praying, magical ceremony, holiday') - was performed after sowing the spring corn. This festivity was so named because hens were sacrificed at public praying (one hen from each house). The birds were killed on a river-bank, where the ceremony took place, and boiled in a joint cauldron. The blood was poured into a special pit where feathers and down were burnt and bones were thrown into the water. While praying, Mordvinians asked the Supreme God Shkai to grant a good harvest, health for people, fertility for cattle (Evsev'ev 1966: 400). In the myths of the Mordvinians in the Nizhni Novgorod region, a hen (saraz) became the favourite bird of goddess Ange Patiai, the Mother of Gods, because the hen was the only one, after the creation of the Earth, who 
did not refuse to fulfil the goddess's wish to lay an egg every day (Pecherskii 1986: 83).

When someone in the household died, the mistress immediately caught a hen in the yard, for protective purposes, and cut its head under the door of the shed or under the gate. Mordvinians threw hen's legs into the grave of a dead man and put a hen's head on the bosom of a dead woman, so that she could have eggs and chicks in the next world.

For the same protective purposes, various bans were imposed. Thus it was forbidden to bring a piece of bread back home from fieldwork (or the hens will die), or stones (hens will cease to lay eggs) or buttercup, the plant called "hen blindness" (or the hens will get blind). When hens were ill, a special magical praying was performed to Narava ( $\mathrm{mdM}$ ), the deity-patroness of creeping grass (Devyatkina 2004: 67). Mordvinians believed that if a piece of straw was stuck to a hen's tail or if the hen flew out of the smoke window of a bath-house, or if it crowed (UPTMN 2003: 154), the deceased was expected in the household. It was believed that a hen's crowing (foreboding a misfortune) could be neutralised, if the master of the house killed the hen, took out its throat, burnt it and threw the ashes to the wind. It was considered that if a hen laid eggs or hatched chicks secretly - the family would grow poor; if a hen crowed loudly, it signified a quarrel. At house-warming parties, a cock was let in the house and a hen was thrown into the cellar for the deity-patroness of the home - Kudava.

In the Gorodishche district of the Nizhni Novgorod region, Mokshans organised a holiday in honour of Neshkeava, the deity-patroness of the apiary and bee-hives, on the prophet Elijah's Day (August 2). It was obligatory to invite the Supreme God, and Neshkeava, and all deities-patronesses of woods to the feast, including the deities of everything that can be found in the forest (sometimes, e.g., even a fairy of an oak or a stump). A white goose was sacrificed. While praying to the deity of the apiary, people asked to increase the number of hives, to protect them from witches, evil people and damage.

A ritual ceremony to honour Ved'mastorpaz, the deity-patron of water on the whole Earth, was usually organised in September. A white goose, whose head was thrown into the water, was sacrificed to the deity for propitiatory purposes. The head was to be torn off, not cut off, the rest of the bird was eaten by the family. A goose was also sacrificed to Keche Iumo, the Mari God of the Sun (Toidybekova 2007: 103). In honour of the Mordvinian deity of fire - Tolava, a red rooster was sacrificed. Immolation of this bird was also performed in honour of the deity-patroness of kinship and family - Iurkhtava and the deity of bast and logs - Keren' Shochkon' paz, after the end of fieldwork and also before the beginning of ploughing, at the magical ceremony - Keret'ozks, devoted to a wooden plough. During the holiday devoted to White Birch - Inekelu $O z k s$, a ritual was performed whereby the heads and entrails of sacrificed birds 
(rooster, geese and hens) were laid beside the house threshold. Thereafter, all this was dug under the threshold or in the centre of the yard. It should be noted that prior to this, the person conducting the ritual tried to find out, by way of special actions, if the sacrifice (including the birds) appeased the gods and deities.

Birds also act as foretellers. The cuckoo ( $\mathrm{mdM} k u k u, \operatorname{mdE} k u k o$ ) is the most popular prophetic bird whose mythological origin is depicted differently in calendar folklore (Christmas carols, Shrove carols). According to one version, the cuckoo hatched out of the egg of the Great Bird's (mdE Ine Narmun'), or the Great Water Bird (mdE Poksh Ved' Narmun'), who built its nest, made of young girl's hair, in the large field, laid three eggs, hatched the younglings: a nightingale, a cuckoo and a skylark (the cuckoo usually comes out of the first or the second egg) (UPTMN 1981, Ch. 3: 68). According to other myths, the cuckoo is hatched by a heath-cock (or an unknown bird), who built its nest in the first grove, in the first tree, on the first branch, and laid three eggs out of which three nestlings hatched: a cuckoo, a nightingale, and a birdie (UPTMN 1981, Ch. 3: 68). The cuckoo is cuckooing in the first tree, on the first twig, bud, leaf. In the morning, cuckooing marked the beginning of a working day. The cuckoo's appearance is mythical - in Shrove carols it is depicted as a speckled bird with red booties on, its beak is gilded, its crest silky. In myths, the cuckoo was destined to become a domestic bird, however, at first it promised and then refused to fulfil the wish of Ange Patiai, the goddess-patroness of marriage, health, women in childbirth and infants, to lay eggs each day. Due to this, the cuckoo was punished and ousted from the human dwelling to the forest. In addition, the goddess did not allow the cuckoo to build its own nest and ordered it to lay its eggs in the nests of other birds. In order for the cuckoo to remember the broken promise, Ange Patiai made the cuckoo and its eggs speckled. Since then, it cuckoos sadly in the forest, missing a human dwelling-place. According to Mari materials, the cuckoo is deprived of its nest because it had built the nest on the Christian holiday of the Annunciation, when all works were strictly forbidden (Toidybekova 2007: 131).

Mordvinians believed that cuckoos were unborn children. There existed a ban to kill a cuckoo (or a baby will be killed). The children who died un-christened also became cuckoos (Deviatkina 1998: 139). In folklore, the deity-patroness of the woods, Vir'ava, is represented as a cuckoo. According to Heikki Paasonen (1997), the bird that flies in the twilight and resembles a cuckoo in its appearance and size is Shopacha (mdM) or Chopacha (mdE) (i.e. the ghost of the deceased, spectre, or devil).

In Khanty folklore, the cuckoo is represented as a supernatural creature or explained as follows: long time ago, the cuckoo was a woman who ran away from her disobedient children (Mythology 2000: 158). 
For the Mordvinians and other ethnoses, (in particular the Mari), cuckooing was a way of determining the period of one's own life. In this case, people would ask the bird: "Cuckoo, cuckoo, how long am I to live?", or as another option, young girls would sometimes as the cuckoo: "How many years are there left before I marry?" (Devyatkina 2004: 56)

The first cuckooing was associated with a number of omens and beliefs: cuckooing heard from the right side meant wealth all year round until the next cuckooing in spring, while cuckooing from the left side betokened hunger. Cuckooing in autumn meant a long and warm spring (Deviatkina 1994: 49). Cuckooing heard from the East was a good sign, from the West - a bad one. Cuckooing heard from the East promised bumper crops, from the South the birth of male babies, from the West - a young girl's death. Frequent cuckooing promised no good or, on the contrary, sunny weather. Cuckooing during the harvest was considered to have a magic meaning. If someone happened to hear it at that time, he/she was to turn in order to face the place from where cuckooing was heard. It was believed that in this case one would not have a sore throat until the next harvest. St. Peter's Day (July 12) was associated with the end of the period of cuckooing, and it was a bad omen to hear it after this day.

Particularly honoured and prophetic bird is the pigeon (mdM gul'nya, mdE gul'ka'). According to Mokshan views, it is shkaen' narmon'('divine bird'), an anthropomorphic creature. In several mythological tales the bird is dealt with as if it were a human being - loman' ('a man'). Due to this, eating doves and pigeons was strictly forbidden, it was a sin never to be forgiven. Likewise, there were taboos concerning the destruction of their nests, lest a pigeon or a dove would bring fire in its beak, set a house on fire and kill the family.

In calendar and ritual poetry (Christmas carols), the behaviour of pigeons and doves reminds one of a human activity: a pigeon (or a dove) bakes cakes of grains that it had brought in its beak, ground and sifted, spreads butter on them, and treats children by singing Christmas carols to these cakes. In mythological songs, a young girl turns into a dove. In wedding folklore, a dove symbolises the bride's tenderness and meekness (she is a domestic dove) (Deviatkina 1992: 24). In traditional Erzian wedding rituals, the twelfth layer of the main ritual pie luvon' $k s h i$ was decorated with two figures (four in the Ardatovo district) of pigeons made of pastry, the pigeons symbolising divine power and future peaceful life.

Even today, people believe that a dove flying through an open window means misfortune. If a dove only knocks at the window, it means a piece of news or a warning of danger (Deviatkina 1992: 61), especially of a house on fire. Doves and pigeons were also referred to in fortune-telling practices. The weather 
was predicted by the flight of pigeons set free on the Epiphany (to which side the pigeons would fly, from there rain would come) (UPTMN 2003: 113).

Mordvinian mythological worldview reflects the image of the pigeon in embroidery as well. In particular, some patterns on shirts resemble the shape of pigeon's traces (mdM gul'kan'pil'gekit) or bird wings (mdM patsianiat).

Likewise, there are infrequent references of cursed birds, in particular, the buzzard (mdE panzei, panzi). According to a legend, after the creation of the world, the God ordered all birds to dig an individual well for each of them to wash there. Everyone obeyed, apart from the buzzard who was absent at the moment. When it finally arrived it decided to use trickery and get a well for free - thus, the buzzard suggested the crow should go and wash itself of silt to appear in front of the God clean. Meanwhile, the buzzard soiled itself with silt, flew to God before the crow and said that it had also dug a well and pointed to that of crow's as if this was its own. God cursed the buzzard for deception and prohibited the bird from drinking water from rivers, lakes and wells. Since that time the bird is able to slake its thirst only with rainwater and dew, and when it has not been raining for a long time, the buzzard begins weeping and asks God for water (UPTMN 1983: 190).

A number of proverbs and sayings have emerged on the basis of the abovementioned legend, e.g., Mokshas-Mordvinians say of those, who like to make use of other people's work: Panzit' kondiaks vadend'sy priants i miar'gi: eshit' mon shuvine 'Like a buzzard who soils its head and says: I have dug a well'.

Images of birds were used in some incantations, e.g., against eyesore according to a mythical plot there is in an enormous elm by the sea where Ine Narmun' (mdE 'great bird') is sitting and pecking the disease to pieces with her beak (UPTMN 1981, Ch. 3: 203).

Birds as foretellers of weather. Mythological folk beliefs are also reflected in popular omens about the weather, associated with the behaviour of birds. People watched the time of birds' arrival: Kda pozdna saikht' narmottne, kizos' uli kuvaka (mdM 'If birds arrive late, summer will be long'); behaviour: Kda narmottne liendikht' mekovasu, pizem tui (mdM 'If birds fly in a bustling manner, it will rain'); location: Kukus' kukai kos'ke shufta priasa - iakshama uli ( $\mathrm{mdM}$ 'If a cuckoo is cuckooing in a dry tree, it means cold weather') (Deviatkina 1994: 49). Cold weather, warm weather, and rain are predicted by the birds' cry, behaviour or play: rain was expected when varsikhne piak karknaikht' (mdM 'crows croak loudly'), chavkatne nalkhksikht'(mdM 'jackdaws gambol'), kir'khksne modasa esheliaikht' (mdM 'sparrows bathe in dust'), oziakatne veli pryt' (mdE 'sparrows fly to a village'). Fine weather was expected when gul'niatne moraikht' (mdM 'pigeons coo'), kir'khksne piak chil'niaikht' (mdM 'sparrows chirp loudly') (UPTMN 2003: 76-78). 
Scientists have ascertained that the presence of special air bags and cavities in the bodies of birds allow them to feel changes in the atmospheric pressure, e.g., their flying low usually precedes bad weather. Mordvinians used to determine, by the appearance of birds, whether the coming spring would be warm or cold: Kda vir' iaksiarkne saikht' af kuiat, tundas' uli liambe (mdM 'If wild ducks arrive skinny, the coming spring will be warm'), and on the contrary Kda vir' iaksiarkne saikht' kuiat, tundas' uli iakshama ('If wild ducks arrive fat, the coming spring will be cold'). Early arrival of chavkatnen'i zhavoronkatnen' ('jackdaws and skylarks') meant warm spring. Likewise, the particular behaviour of birds could predict a snowstorm sez'ganos' kekshni krysha alov (mdE 'a magpie hides itself under the roof') or snowfall: Alga etaikht' vir'matsikhne kurok lov prai (mdM 'Wild geese fly low, snow will fall soon'). The coming of colds was expected when migrating birds flew away early: Buti lokseitne tuit' rana seksnia, boikasto syt' iakshamotne' ( $\mathrm{mdE}$ 'If swans fly away at the very beginning of autumn, cold weather will come quickly afterwards') (UPTMN 2003: 79).

Quite remarkable is the behaviour of domestic birds: Sarazos' tarksesynze es' tolganzo-pogodan' polavtomanten' (mdE 'If hens clean feathers, it means bad weather'); Buti saraztne lisnit' pizemen' shkasto, kurok pizemes' iuty (mdE 'If hens come out during the rain, the rain will be over soon'). As an omen of rain, hens pinch their feathers, bathe in dust, hide themselves in the daytime. As a sign of the autumn coming, they clean their feathers. Predicting a cold winter, they drop their feathers in autumn; if a hen dropped her tail, she would not lay eggs anymore. People also believed that when a hen wetted her leg on St. Evdokia's Day (i.e. that it thawed a little), summer would be fine (UPTMN 2003: 112). By untimely crowing of cocks, people expected the arrival of warmth: Atiakshtne karmit' moramo ran'she-lembes ( $\mathrm{mdE}$ 'Cocks begin to crow earlier than usual, it means warmth'); Tialonda iliat'atiakshne kukoriaikht'-liambondi (mdM 'Cocks crow at daytime in winter, it means warmth').

The omens about rain, associated with the behaviour of sparrows, are widespread among the peoples of the Volga region (Mordvinians, Maris, Chuvashs, Russians).

\section{ABBREVIATIONS \\ $\mathrm{mdE}=$ Erzian language \\ $\mathrm{mdM}=$ Mokshan language}




\section{REFERENCES}

Deviatkina, Tatiana 1992. Mokshanskie suadebnye obryady i pesni. [Mokshan Marriage Rituals and Songs.] Saransk : Mordovsk. knizhoe izdatel'stvo.

Deviatkina, Tatiana 1994. Narodnye primety mordvy-mokshi. [Mokshan and Erzian Folk Signs.] Saransk: Izdatel'stvo Mordovskogo universiteta.

Deviatkina, Tatiana 1998. Mifologiia mordvy. Entsiklopediia. [Mordvinian Mythology. Encyclopaedia.] Saransk: Mordovskoe knizhnoe izdatel'stvo.

Deviatkina, Tatiana 2002. Moksherzian' mifologiias'. [Mosha-Erzian Mythologies.] Tartu: Estonian Literary Museum. http:/haldjas.folklore.ee/rl/folkte/sugri/ mordva/ersa/myto2/koi-8/, last accessed on 20 August 2011.

Deviatkina, Tatiana P. 2007 [1998, 2006]. Mifologiia mordvy. Entsiklopediia. [Mordvin Mythology: Encyclopaedia.] Saransk: Krasnyi oktiabr.

Devyatkina, Tatiana 2004. Mordvinian Mythology. Ljubljana: SRZ/SAZU.

Evsev'ev, M. E. 1966. Izbrannye trudy. T.5 Mordovskaya svadba. [Selected works. Vol. 5. Mordvinian wedding.] Saransk: Mordovskoe knizhnoe izdatel'stvo.

Harva, Uno 1952. Die religiosen Vorstellungen der Mordwinen. Folklore Fellows Communications 142. Helsinki: Academia Scientarum Fennica.

Mythology 2000 = Mifologiia khantov. [Khanty Mythology.] Tomsk: Izdatel'stvo Tomskovo Universiteta.

Myths 1994 = Mify narodov mira. Entsiklopediia. Vol. 2. [Myths of the Peoples of the World. Encyclopaedia.] Moscow: Rossiiskaia entsiklopediia.

Pecherskii, Andrei 1986. Ocherki mordvy. [Mordva: An Overview.] Saransk: Mordovskoe knizhnoe izdatel'stvo.

Paasonen, Heikki 1977. Mordwinische Volksdichtung 5. Helsinki: Suomalais-Ugrilaisen Seuran Toimituksia.

Toidybekova, Lidiia 2007. Mariiskaia mifologiia: Etnograficheskii spravochnik. [Mari Mythology: Ethnographic Reference.] Ioshkar-Ola: MPIK.

UPTMN 1963 = Kavtaskin, L. S (ed.) Ustno-poeticheskoe tvorchestvo mordovskogo naroda. Tom 1. [Oral-Poetic Folklore of the Mordvinian People. Vol. 1.] Epicheskie i liroepicheskie pesni. [Epic and Lyroepic Songs.] Saransk: Mordovskoe knizhnoe izdatel'stvo.

UPTMN 1981 = Imaikina, V. L. \& Samorodov, K.T. (eds.) Ustno-poeticheskoe tvorchestvo mordovskogo naroda. Tom 7. Ch. 3. [Oral-Poetic Folklore of the Mordvinian People. Vol. 7. Ch. 3.] Kalendarno-obryadovye pesni $i$ zagovory. [Calendar and Ritual Songs and Incantations.] Saransk: Mordovskoe knizhnoe izdatel'stvo.

UPTMN 1983 = Sedova, L. V. (ed.) Ustno-poeticheskoe tvorchestvo mordovskogo naroda. Tom 10. [Oral-Poetic Folklore of the Mordvinian People. Vol. 10.] Legendy, predaniya, bylichki. [Legends, Tales, Short Epic Stories.] Saransk: Mordovskoe knizhnoe izdatel'stvo.

UPTMN 2003= Deviatkina, Tatiana (ed.) Ustno-poeticheskoe tvorchestvo mordovskogo naroda. Tom 12. [Oral-Poetic Folklore of the Mordvinian People. Vol. 12.] Narodnye primety mordvy. [Folk Signs of the Mordvinian People.] Saransk. Krasnyi oktiabr. 


\title{
RITES ASSOCIATED WITH CONJURING RAIN IN THE UDMURT CALENDAR CYCLE
}

\author{
Tatiana Vladykina, Galina Glukhova
}

\begin{abstract}
Several archaic features of interpreting the surrounding world are still present in Udmurt folk culture. Calendar-related customs and feasts still preserve the oldest elements on all levels of rituals: in activities, artefacts, verbal and acoustic fields, etc. The dismissal of pests and caterpillars, and their wedding rituals, are deeply rooted in calendar customs. The thorough study of the codes of these rituals would help to determine the semantics of rituals, ascertaining the synchronic-diachronic aspects of the calendar and provide an integral imagination with regard to the mythopoetic foundations of popular worldview. Relying on the analysis of the specificity of Udmurt calendar feasts and customs, it becomes obvious that the tradition of warding off insects and caterpillars takes place in different seasons and is an inseparable part of the calendar cycle. Having analysed the specificity of Udmurt calendar feasts and customs, the rituals associated with the dismissal of insects is intrinsically polyfunctional, whereas the most archaic feature therein is the idea of conjuring the rain.
\end{abstract}

Key words: conjuring the rain, Udmurt folk tradition, warding off/wedding of insects and pests, Water Mother

Several archaic features of interpreting the surrounding world have been preserved in Udmurt traditional culture. The rituals regulating the behaviour of human beings in nature and society have actually remained in the focus of social and spiritual life. Up until today, calendar customs and feasts have maintained the oldest elements of rituals at all levels: in activities, artefacts, verbal and acoustic parts, etc. Thorough study of the different codes of rituals helps to ascertain the semantics of these rituals, determine the synchronic-diachronic calendar related aspects, and provide an integral picture of the mythopoetic foundation of the popular worldview. The observation of the specificity of Udmurt calendar feasts and customs, in the context of traditional culture, enables to see their functioning from a new side and solve various worldview-related and culturological problems. The aspects of Udmurt folk calendar have been studied by researchers since the end of the 19th century (Vereshchagin 1886 [1995], 1889 [1996]; Pervukhin 1880-1888; Gavrilov 1891; Vasil'ev 1906; Perevozchikova 1993; Vladykin 1994; Khristoliubova 1995; Vladykina 1998; Minniiakhmetova 
2000 and others). In this article, we observe the rituals for conjuring rain, which have so far been unfortunately been given little attention. Such rituals comprise нумыр келян/сюан - 'sending away/weddings of vermin', урбо келян/ сюан-sending away/warding off/weddings of bedbugs. Traditionally, these rituals are conducted according to the relevant need, the content and terminology of the ritual are directly focused on the extermination of the insects, without any other hidden purpose. In the light of new data, folk calendar related customs and wedding rituals, together with the mythological semantics of the inherent elements, can be reviewed in order to redefine the functional determination of the above-mentioned rituals. As the details of these rituals are of great significance, let us further focus on the local versions.

\section{CUSTOMS CONCERNING INSECTS AND VERMIN}

The ritual of "the survival of bedbugs" has been recorded in the 19th century from among the Udmurts of the Sharkan area (currently one of the central regions of Udmurtia); this ritual was conducted on the night prior to Holy Thursday, and it was believed, in order for it to be effective, that the ritual had to be conducted by an expert or at least a person who had learnt this practice from an expert (Vereshchagin 1995: 112). On the night of Holy Thursday or early in the morning, before dawn, the lady of the house invited the expert to look for bedbugs (урбо утчаны), who turned the found insects (no less than three) into white canvas and tied this as a knot on top of the rod, and hung a copper bell lower down on the stick. Thereafter, he sat astride on the rod, as if on a horse and "rode" towards the river, singing a wedding song (Vereshchagin 1995: 112-114).

The relevant ritual among the Udmurts living in the territory of today's Tartar was the wedding of bedbugs (урбо сюан). Several women gathered in a house, and one of them was decorated as a bride (виль кышно), whereas the obligatory element of clothing was a large headscarf with thrums (быркенчи). Thereafter, imitating a wedding procession, they moved from house to house and collected bedbugs in a box. After finishing the movement though yards, the "bride" was put on the sledge (in winter) or a wagon (in summer) and was taken to the valley or ravine behind the village where she began to lament:

Монэ татсы кытсы куштыса кельтиды?

Кинлы ваиды ти монэ?

Why did you leave me here?

Who did you bring me here for? 
The others ran away and left her there alone. She sat there in silence for a while, then threw the box with bedbugs in the ravine and returned to the village.

In one of the variants (current Kiiasovskii region in the southern part of the Udmurt Republic), a bug was put into an old birch-bark shoe, people headed towards the river while singing a wedding song (сюан гур) and then threw the shoe, with the bedbug therein, into the water (Vladykin \& Churakova 1986: 125).

Another ritual, practised by the Northern Udmurts in the summer-time was the sending away of cabbage-worms (нумыр келян) - for this purpose, 1020 children and some old women came together and, when moving after each other along the furrows in the vegetable garden of each participant, they picked up worms from cabbage leaves and put them into an old worn birch-bark shoe. When walking though all vegetable gardens, the women unpleated their hair, and tinklers or wooden cowbells were put around children's necks. Accompanied with noise, shouting and bell-ringing, the procession moved to the pond, trying not to drop any of the cabbage-worms. Then, standing on the foot-bridge and singing a wedding song, the birch-bark shoe was thrown into the water. The participants came back in silence, attempting not to make any noise at all.

The above-described is similar to the caterpillar wedding (нумыр сюан) practiced prior to Midsummer among the Udmurts in Zavialovsk area. In the evening, the entire village gathered in a vegetable plot of one of the inhabitants. Women wore folk costumes and put on colourful headscarves, and men had to wear a colourful shirt and cap. A large table was put in the vegetable garden, covered with a white tablecloth. The table was laid with bread, salt, vegetables (potatoes, tomatoes, cucumbers) and fresh honey. Everyone stood around the table and tasted the food, and the merrymaking part commenced after this. Young people took a cabbage leaf in one hand and a poppy flower in the other, and sang:

Коркалэн шулдырез нэнэй-дядяй вань чоже, / Азбарлэн но шулдырез пиналъёс но вань дырья. / Кенослэн но шулдырез нылъёс но вань дырья. / Возь выллэн но шулдырез выль кенак но вань чоже. / Ульчалэн но шулдырез гырлыё вал вань дырья. / Бакчалэн но шулдырез мак сяська вань дырья. / Мусо, мусо, кудое, кочон кудое, / Эшшо но мусо кубиста туклячие. / Кибыдэ но нумырдэ ми сьорамы нуомы. / Зечсэ ми бакчае кельтомы, / Уродзэ сьорамы басьтомы. / Пичи но вань, бадзым но вань, / Ваньды улляськелэ ми сьоры

It is joyful in the cabin when mom and dad are alive, / it is jolly outside when children are in the yard./ It is joyful inside as long as girls are 
there./ Meadows are pretty as long as there are brides./ The street is merry with horses and bells (on the shaft-bow)./ The beauty of the garden is in blooming poppies./ Handsome and pretty is my best man cabbage root,/ even sweeter is the cabbage-in-law./ Insects and worms we take with us./ Leaving everything that is good in the garden,/ taking all bad with us./ Here are the young, here are the old,/ let us all come with us.

While singing, elderly women walked along furrows and picked cabbage worms.

Conclusions can be made from the described cases that the warding off of insects and cabbage worms was strictly limited to the period from the Holy Thursday to Midsummer. According to ancient beliefs, the Holy Thursday was the threshold of the New Year. People believed that on this night the deceased would come to visit those alive, ghosts would wonder about (жобъёс, ишанъёс), and witches become active. There were certain practices to keep away from the evil force and send it back to the otherworld (e.g. the ritual for ousting the devil - шайтан уллян / урай). The beginning of the week, up until the Holy Thursday was the time for cleaning the abodes of people and the surrounding environment. Village women organised joint workdays (веме), and washed the floors, ceilings and walls in every house, one after another. Thus, in this context it is not accidental that the period for warding off insects is directly associated with the cleaning rituals of the Holy Thursday (cf. the "funerals" of insects and the warding off of pests among the Komi: Mikushev 1973: 36; Latysheva et al. 2009: 29-31).

\section{THE AGRICULTURAL YEAR OF THE UDMURTS}

According to Udmurt (agricultural) folk calendar, the year was generally divided into two parts: both spring and autumn were considered the beginning of the new year. In the 19th century, Grigorii Vereshchagin wrote that the Udmurts count the new year from the time when field work starts: "Although they [Udmurts] refer to the first day of January as the New Year (выль ар), it does not mean anything to them; this date is called the New Year merely because of the fact that civil servants and all fixed-date services commence and end on this day." (Vereshchagin 1995: 35)

The customs associated with the spring-time new year involve the rituals of ploughing the first furrow (Акашка/Акаяшка/Гырыны потон/Геры поттон - 'going to plough, plough feast'), and are actually amalgamated with Christian Easter Быдзыннал/Великтэм/Паска). The celebration of the New Year in au- 
tumn, however, has preserved fragmentally in Udmurt folk tradition. Some of the Northern Udmurts are still using the parallel corresponding terms for spring-summer and autumn-winter periods: ву вылын сылон ('standing on water', August 19) and йо вылын сылон ('standing on ice', August 19). Thus, we could presume that the period from Holy Thursday to approximately midAugust was dealt with as a whole year in old Udmurt tradition. In other words, the autumn-winter half-year and the spring-summer half-year were understood as independent time units. The fact that both of these semi-annual periods were seen as a separate year is proved in the expression used by the Northern Udmurts: гужемен-толэн улыны ('to live through a summer and winter'), which actually means to live a whole year (cf. with the Russian expression Сколько лет, сколько зим 'many summers, many winters'). Each half-year was considered full and whole. Upon the conversion to Christianity, these halfyears were merged and the St. Elijah's Day was regarded as the beginning of the autumnal half-year. This can be presumed from the Udmurt word Выль/ Виль нунал ('new/ new day'), (nowadays, this term is solely associated with the fresh-harvested crop) which explicitly indicates the beginning of a new cycle after the summer solstice (инвожо). This argument is also supported by the fact that the Udmurt notion ap ('year, time') has a counterpart in the Komi language where ap [ar] denotes autumn (Alatyrev 1988: 98-99).

It was probably due to the seasonality of the "sending away of insects" and their late association with the cleaning rituals why the former are solely interpreted as warding off-rites. However, the relevant archaic semantics is revealed when observing the allocation of roles among the participants, the attributes, musical accompaniment and the symbolic imagery of the songs.

The wedding related symbolism of the observed rituals is particularly explicit: the ritual is an imitation of a wedding procession (a rod with a bell instead of the horse, a female participant dressed as a bride, women dragging the sledge with a "bride"), accompanied by wedding songs. The abundance of wedding plots and symbols in the given examples is "on one hand conditioned by typological similarity [thereof] with family and calendar feasts and rites of passage: there are records of local variants of autumnal masked imitations of wedding procession; wedding songs have an important place in Shrovetide customs. [...] Likewise, the autumnal commemoration ritual, sacrificing the head or legs of a cow or a horse (йыр-пыд сётон) is also accompanied by wedding melodies." (Vladykina 2006: 54) On the other hand, the wedding theme has probably become actualised as a polysemantic ritual-magical set of customs to ward off insects, the main function of which used be the conjuring of the rain. The initial idea of this tradition disappeared in the time-wise later strata along with the loss of archaic mythological beliefs. However, this initial idea did not 
disappear from calendar rituals the aim of which was to prevent drought. Differently from other "more understandable" rituals, this occurred to be most saturated with symbols.

\section{PRESERVING WATER BODIES AND CONJURING THE RAIN}

Before the start of spring at the beginning of the agricultural calendar, the Udmurts attempted to avoid a potential accident. Nearly all the prayers and charms of the spring-summer-time calendar feasts include an appeal to gods to send rain (зор) or humidity (мускыт): “... Гужем нуналын шуныт-лэськыт нуналъёстэ ке сётсал, небыт зоръёстэ сётсал ке...” 'If you could give warm and soft days in summertime, warm rainfalls if you could send...' (Vasil'ev 1906: 341-342).

To preserve indispensable humidity, Udmurts appealed directly to elemental forces, springs of water. A characteristic example of this is the ritual of the Northern Udmurts conducted during the break-up of ice on rivers - the sending away of ice (йо келян). The entire village, dressed in festive garments, goes to the riverside, with ritual food and drinks. After sacrificing, people start to host each other and entertain themselves on the bridge. The aim of the feast and sacrifice is to bring a treat to the rivers (куасьмылысьтэм мумыос'never-drying mother-rivers', визыл бызись ю-шур мумыос - 'foremothers of peacefully flowing rivers') (Pervukhin 1880-1888: 9-10), and afterwards a prayer is uttered to the spirit of the river (ву-кузё/вумурт) to give water to people and the herds, wet the fields and avoid drought and famine, fires and epidemics. The most important part of this water cult concerns the attitude towards the springs of water, and this was actualised during summer solstice (инвожо-дыр). The status of springs, their sacredness is underlined by rules forbidding the desecration of the bodies of water: "It is not allowed to do laundry in our spring: thunder would come." Outbursts of diseases (boils and sloughs on the human body) were explained as violations of prescriptions (taboo). According to folk belief, the springs need particular attention during "dangerous" times. At midday it was forbidden to fetch water with a sooty cauldron or to make noise at the spring. A custom has been recorded from among the Northern Udmurts that water was not fetched until four o'clock p.m., and the spring was covered with a white tablecloth as protection from the "evil" Sun during a dangerous transitional period.

Drought was considered to be the punishment of gods for the violation of generally valid norms, for incomplete adherence to calendar rituals and was attempted to be resolved by the rite to conjure up rain (зор курон). This was 
basically the only episodic ritual, within the agricultural calendar, practiced pursuant to a relevant need. It was presumed that ritual-magical acts would bring about the desired outcome: old women and children poured water on each other at the riverside and pushed each other into the water; in some occasions, a black or grey ram was taken to the riverside and pushed into the water; in the village, the passers-by were soaked and even poured over; even houses, fences and gates were splashed with water. Soil was taken from the bottom of the spring and thrown at each other and window panes; mud was not wiped from the windows as it had to be the rain to do this. A somewhat more modest variant of the conjuring of the rain is ritual eating of porridge (Жук сиён), when one or two elderly women gathered five-to-six-year-old children to the riverside, made porridge in a large pot and "gave" this to the river and the participants in the ritual.

The customs associated with the conjuring of the rain would not be complete without the ritual for warding-off insects, the symbolism of which combines intertwined archaic and newer layers, becoming especially evident in the relevant action (cf. with similar materials regarding Slavic culture: Gura 1995a: 491; Gura 1995b: 355; Gura 2004: 370-371).

Such manipulations with insects (gathering them in an old birch-bark shoe, box, cloth, cabbage leave; throwing them into the river or ravine) reveal the ancient layers of the religious worldview about the polysemantic connection between the water and its masters, reconstructed on the basis of old incantation texts. The waters above the ground are under the protection of the water spirit (вумурт - 'water man') of relatively later origin; the celestial water in heaven - creative, first-born - is under the protection of celestial ancestress Water Mother (Northern Udmurt Ю-Кылчин, Southern Udmurt Инву-мумы/ Инву):

Быдзым Иньмарлы, Кылчинлы, Ю-Кылчинлы, Мумы-Кылчинлы, Музъеммумылы пияз пониськом, мед далтытоз! Зеч ардэ сёт, шуныт уйдэ сёт, шуныт зордэ сёт, лысвудэ сёт...!

To great Inmar, Creator-Kylchin, to Water-Ancestress/Water - Creative Mother, to mother-ancestor, mother-earth we put [a sacrifice] in her bosom, let [the crop] grow! Give a good year, give warm nights, give warm rain, give dew...! (Wichmann 1893: 123-124)

Invu (celestial water/moist) is also the protector of kinship. In several local traditions, people appealed to him, besides the trinity of upper gods and the deities of kinship (Будзым Инмаре, Инэ-вуэ, воршудэ... 'Great Inmar, Ine-vue [great celestial water], Vorshude'). The prayer was accompanied with whistling, whereas the tune played at the moment of uttering the prayer was called 
инву утчан гур ('the tune to search for celestial water'). The same tune was played when the tuno (туно - 'shaman, soothsayer') fell into a trance during the ritual when was choosing a successor to himself. Invu was approached to receive blessing for clairvoyance, during the foretelling practice, when choosing a sacrificial site and determining the sacrificial animal. The melody of celestial moist (Инву гур) was performed during the furrow-feast (Гершыд), denoting the end of spring-time field work. The imagination of celestial water (invu) thus contains the idea of divine blessing granted by an ancestor. Might be that it is indeed this particular idea that is the wedding related element in the ritual for conjuring the rain, as one of the main characters assumes the role of the bride/young married woman (выль кен). The absence of this character is compensated with the wedding tune accompanying the ritual. The erotic symbolism of the songs sung at this moment (comparison of male and female genitals with vegetables - cabbage root or cabbage) might, in our view, convey the same idea. The hypostasis of the Water-Mother is revealed more clearly in using cabbage worms in the rituals for conjuring the rain, as the image of cabbage-vulva is a permeating feature in Udmurt calendar related customs (particularly frequent in autumnal masking songs; the stuffed Shrovetide bogey is also referred to as Auntie Cabbage).

The female water deity is polyfunctional and multi-faceted in the culture of a number of peoples (Rabinovich 1987). The anthropomorphic figure of Invumumy (celestial Mother Water) was probably preceded by her archaic hypostasis - a water snake, the mundane projections of which were insects (bedbugs, vermin) (Kozlova 2006: 40ff). The Udmurts gave a sacrifice to water, imitating, at the same time, the return to homely circumstances.

Proceeding from the above, it can be said that the customs concerning the sending away of insects are adjusted to specific seasons, the former being an inseparable part of the calendar cycle, therefore not random. The rituals for sending away insects are polyfunctional whereas the most archaic function is the idea to conjure the rain.

\section{REFERENCES}

Alatyrev, Vasilii 1988. Etimologicheskii slovar' udmurtskogo iazyka: Bukvy A, B. [Etymologcial Dictionary of the Udmurt Language: Letters A, B.] Izhevsk: NII pri SM UASSR. http://api.ning.com/files/SCiUu6Te4gWSk8pa*full67pB3cluw4KJCf9G9Vzfd0EsynMFD42U2UiWPybc05ej5W11QT6tjNcluKOXk-C2Gix9On4Vmd/ alatyrevetymology.pdf , last accessed on 10 August 2011. 
Gavrilov, Boris 1891. Pover'ia, obriady i obychai votiakov Mamadyshskogo uezda, Urias'Uchinskogo prikhoda. [Votyaks of the Mamdyshskii Uezd: Beliefs, Customs and Teachings.] Trudy IV Arkheologicheskogo s"ezda $v$ Rossii 2. [Papers of the 4th Conference on Archaeology in Russia 2.] Kazan.

Gura, Aleskandr 1995a. Gady. [Reptiles.] In: N. Tolstoi (ed.-in-chief). Slavianskie drevnosti: Etnolinguisticheskii slovar'v 5-ti tomakh 1:A-G. [Slavic Heritage: Ethnolinguistic Dictionary in 5 volumes. 1: A-G.] Moscow: Mezhdunarodnye otnosheniia.

Gura, Aleskandr 1995b. Zmeia. [Snakes.] In: N. Tolstoi (ed.-in-chief). [Slavic Heritage: Ethnolinguistic Dictionary in 5 volumes. 2: D-K (Kroshki).] Moscow: Mezhdunarodnye otnosheniia.

Gura, Aleskandr 2004. Nasekomye. In: N. Tolstoi (ed.-in-chief). [Slavic Heritage: Ethnolinguistic Dictionary in 5 volumes. 3: K (Krug) - P (Perepelka).] Moscow: Mezhdunarodnye otnosheniia.

Khristoliubova, Liudmila 1995. Kalyk siam"esty chaklasa (Udmurtskie narodnye obychai). [Udmurt Folk Beliefs.] Izhevsk: Udmurtiia.

Kozlova, Natal'ia 2006. Vostochnoslavianskie mifologicheskie rasskazy o zmeiakh. Sistematika. Issledovanie. Teksty: Monografiia. [Mythological Stories about Snakes among the Eastern Slavs. Systematics. Research. Texts: Monograph.] Omsk: Izdatel'skii dom Nauka.

Latysheva, Vera \& Ostapova, Elena \& Filippova, Valentina 2009. Iazyk poezii komi. Monografiia.[Poetic Language of the Komi. Monograph.] Syktyvkar: Izd-vo Syktyvkarskogo un-ta.

Mikushev, Anatolii 1973. Epicheskie formy komi fol'klora. [Epic Forms of Komi Folklore.] Leningrad: Nauka.

Minniiakhmetova, Tatiana et al. 2000. Kalendarnye obriady zakamskikh udmurtov. Monografiia. [Calendar Related Customs of the Udmurts beyond the Kama River.] Izhevsk: Udmurtskii institut istorii, iazyka i literatury Ural'skogo otdeleniia Rossiiskoi akademii nauk.

Perevozchikova, Tatiana 1993. Predstavleniia o mire i narodnyi kalendar'. [Worldview and Folk Calendar.] In: V. Pimenov (ed.) Udmurty: istoriko-etnograficheskie ocherki. [Udmurts: Historical-Ethnographic Overview.] Izhevsk: Udmurtskii institut istorii, iazyka i literatury Ural'skogo otdeleniia Rossiiskoi akademii nauk.

Pervukhin, Nil 1880-1888. Eskizy predanii i byta inorodtsev Glazovskogo uezda. Eskiz III. [Studies of Folk Tales and Everyday Life among the Minorities of the Glazovsk Uezd. Vol. 3.] Viatka.

Rabinovich, Elena 1987. Boginia-mat'. [Mother-God.] In: S. Tokarev (ed.) Mify narodov mira. Entsiklopediia (v 2 tomakh) I (A-K). [Myths of the Peoples of the World. Encyclopaedia (in 2 volumes) 1 (A-K).] Moskva: Sovetskaia Entsiklopediia, pp. 178-180.

Vasil'ev, Ioann 1906. Obozrenie iazycheskikh obriadov i verovanii votiakov Kazanskoi, Viatskoi gubernii. [An Overview of Linguistic Rituals in the Folk Belief of Votyaks in the Kazan and Viatka Guberniyas.] Izvestiia Obshchestva arkheologii, istorii i etnografii pri Imperatorskom Kazanskom universitete 5. [Journal of the Society 
of Archaeology, History and Ethnography at the Imperial Kazan University.] Kazan.

Vereshchagin, Grigorii 1886 [1995]. Votiaki Sosnovskogo kraia. Sobranie sochinenii v $6 t$. [Votyaks of the Sosnovsk District. Collected Papers in 6 Volumes.] I. Izhevsk: Udmurtskii institut istorii, iazyka i literatury Ural'skogo otdeleniia Rossiiskoi akademii nauk.

Vereshchagin, Grigorii 1889 [1996]. Votiaki Sarapul'skogo uezda Viatskoi gubernii. Sobranie sochinenii $v 6 t$. [Votyaks of the Sarapul'sk Uezd, Viatka Guberniya. Collected Papers in 6 Volumes.] II. Izhevsk: Udmurtskii institut istorii, iazyka i literatury Ural'skogo otdeleniia Rossiiskoi akademii nauk.

Vladykin, Vladimir 1994. Religiozno-mifologicheskaia kartina mira udmurtov. Monografiia. [Religious-Mythological Worldview of the Udmurts. Monograph.] Izhevsk: Udmurtiia

Vladykin, Vladimir \& Churakova, Rimma 1986. Obriad “iyr-pyd seton"”v pominal'nom rituale udmurtov. [The "iyr-pyd seton" rite in the commemorative customs of the Udmurts.] In: I. Rüütel (ed.) Muzyka v svadebnom obriade finno-ugrov $i$ sosednikh narodov. [Music in the Wedding Customs of the Finno-Ugrians and Neighbouring Peoples.] Tallinn: Eesti raamat, pp. 108-133.

Vladykina, Tatiana 1998. Udmurtskii fol'klor: problemy zhanrovoi evoliutsii $i$ sistematiki. Monografiia. [Udmurt Folklore: Issues of Genre-wise Evolution and Systematics. Monograph.] Izhevsk: Udmurtskii institut istorii, iazyka i literatury Ural'skogo otdeleniia Rossiiskoi akademii nauk.

Vladykina, Tatiana 2006. Atributivnye i verbal'nye paralleli v udmurtskom i russkom svadebnom ritualakh. [Attributes and Verbal Parallels in Udmurt and Russian Wedding Rituals.] In: V. Gatsak \& T. Vladykina (eds.) Russkii Sever i vostochnye finno-ugry: problemy prostranstvenno-vremennogo fol'klornogo dialoga. Materialy I Mezhregional'noi konferentsii i VII Mezhdunarodnoi shkoly molodogo fol'klorista. Izhevsk, 23-26 oktiabria 2005 g. [Northern Russia and Eastern FinnoUgrians: Problems Concerning the Time and Space Related Folkloric Dialogue. Materials of the1st Inter-regional Conference and 7th International School for Young Folklorists. Izhevsk, 23-26 October 2005.] Izhevsk: ANK, pp. 50-57.

Wichmann, Yrjö 1893. Wotjakische sprachproben. I. Lieder, Gebete und Zaubersprüche. Suomalaisen-ugrilaisen seuran Aikakauskirja 11: 1. Helsingfors: Suomalaisen kirjallisuuden seuran kirjapaino. 


\title{
THE TALLINN DEPARTMENT OF THE ESTONIAN NATIONAL MUSEUM: HISTORY AND DEVELOPMENTS
}

\author{
Piret Õunapuu
}

\begin{abstract}
The Estonian National Museum (ENM), established in 1909 in Tartu, developed quickly and comprised a large membership in the country - the members living in Tallinn were active in heritage collection and awareness-raising activities, and formed a separate department which gradually gained independence. As an inevitable outcome, the Tallinn Department finally separated from the parent museum. Despite organisational difficulties and political circumstances, the department managed to supplement collections and arrange spectacular events. In 1919, the Tallinn Department of the ENM became an independent Estonian Museum Society in Tallinn, i.e. the Estonian Museum in Tallinn, which, in the course of time, became more inclined toward art and developed into the Art Museum of Estonia.
\end{abstract}

Key words: antiquities, Art Museum of Estonia, Estonian National Museum, folk art, folk culture, German occupation 1917-1918, heather - the museum flower, heritage, lottery, museum parties, open-air museum

\section{INTRODUCTION}

In this article I attempt to provide an overview of how the Tallinn Department of the Estonian National Museum was formed, which in turn evolved into the Estonian Museum Society in Tallinn ${ }^{1}$ and this, in turn, became the Art Museum of Estonia. The fact that both museums have also dealt with their history, associated with the anniversaries, yet have not underlined the explicit connection between these two substantial memory institutions of Estonia, has been the direct reason for writing this article. ${ }^{2}$ At present, both museums focus on distinct subject matter and are not competitors in devising collections or in communication with the public. Ninety years ago, however, things were different and the separation of the Estonian Museum in Tallinn, from the Estonian National Museum in Tartu, was a long and painful process.

The material, kept primarily in the archive of the Estonian National $\mathrm{Mu}$ seum, serves as a basis for the article, whereas the sources used most encompass the diverse loose-leaf material concerning the Tallinn Department of the 


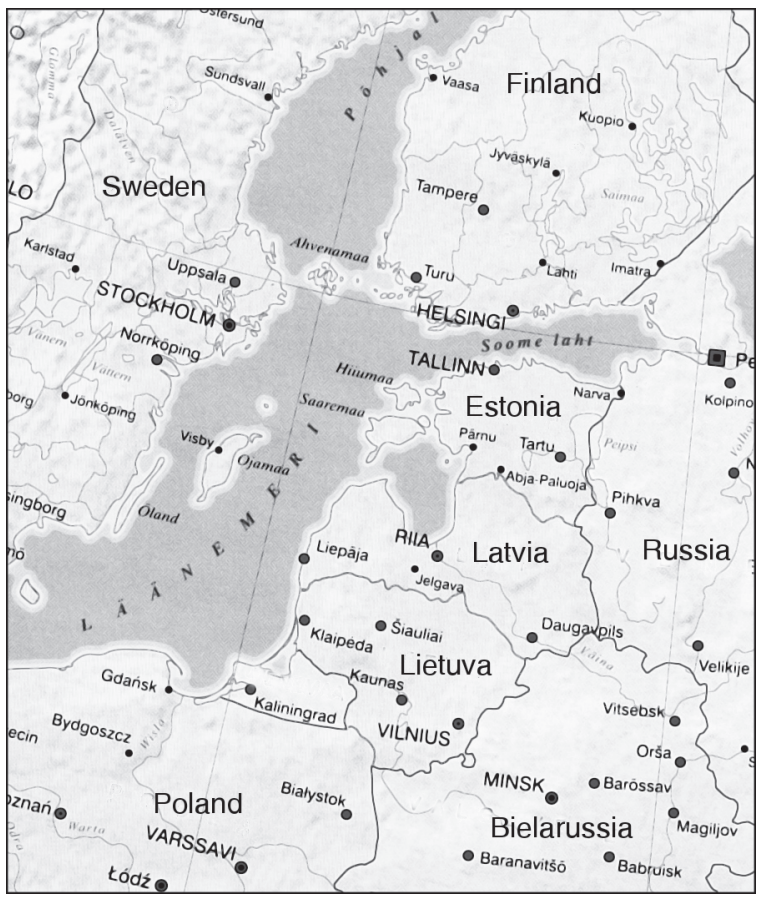

Figure 1. Map of Estonia and neighbouring countries.

Estonian National Museum 1919-1920. The hand-written memories of one of the key figures of the quondam events, August Pulst ${ }^{3}$, are located in the archive of the Art Museum of Estonia, as well as in that of the Estonian National Museum (ENM). Content-wise, this is actually a manuscript of the memories, the initial variant of which is a hand-written draft version, written during the period 1943-1948 and titled The Estonian Museum in Tallinn. Historical data, with abundant corrections and additions (Pulst 1948). The typescript text from 1973, My work in connection with folk art - ethnography, preserved in the ENM, is a more succinct summary written on the basis of the former version (Pulst 1973). Likewise, I have also used the unpublished article by Heini Paas from 2004, entitled About the history of the Estonian Art Museums 1919-1944. Earlier, the same author has published an article About the history of the Estonian State Art Museum, the establishment and history of the museum 19191940" (Paas 1980). However, the earliest and most immediate insight in the subject matter is the article by Bernhard Linde, The development of the idea of the Art Museum of Estonia, and the Estonian Museum Society in Tallinn (Linde 1931).

With regard to the ENM, the establishment of the Tallinn Department is covered in a relatively short overview published in the jubilee edition of the 
Estonian National Museum, 100 Years of the Estonian National Museum (Õunapuu 2009). August Pulst's activities in the Tallinn Department of the ENM, and later in the Tallinn Estonian Museum are outlined in the ENM series of publications of diaries written by heritage collectors (Õunapuu 2006).

\section{THE FIRST YEARS OF THE ESTONIAN NATIONAL MUSEUM}

The process of creating the Estonian National Museum (established in 1909) had been long and cumbersome. What had so far been merely the cherished idea of some enthusiasts - the Estonian museum - now obtained a dignified name - the Estonian National Museum (in Estonian: Eesti Rahva Muuseum, literally: the Museum of Estonian People). At this point it is expedient to dwell upon the selection of the name for the museum. First and foremost, the museum was established to serve as the repository for Jakob Hurt's folklore collections. Indeed, a decision was made at the meeting convened after the funeral of Jakob Hurt, to initiate the Hurt museum, however, quite soon a more comprehensive name - Eesti Rahva Muuseum (Estonian National Museum) was selected to be appropriate and in concord with the increasing amount of relevant work (Leinbock 1934: 4-5). Naturally, it was the forward-looking intelligentsia who primarily realised the significance of the museum in the cultural context.

Collection work was the main aim during the first years. The phenomenon, that the museum, mainly relying on non-remunerated labour force, people who were voluntarily working for their homeland, set a goal to collect as much heritage as possible from all over Estonia, parish by parish, and managed to send dozens and dozens of people to do this work, is unique in the world. The outcome comprised abundant and valuable collections of artefacts stored in the museum prior to the devastating World War I (Õunapuu 2007: 11).

\section{THE STIMULUS FOR SETTING UP THE TALLINN DEPARTMENT}

However, the outburst of World War I had a profound impact on heritage collection for the forthcoming years. The authorities and rural people suspected those collecting the antiquities of espionage and unfamiliar persons walking from village to village seemed suspicious. Thus, the number of collectors decreased - only six people were doing this job in 1915, one of them August Pulst, a student at the Art School of Riga, who continued with what he had started the year before in his home parish Tori. 
The launch of the Tallinn Department of the Estonian National Museum was initiated because of warfare, with the young heritage collector August Pulst in charge. After his 1915 collection trip to Tori parish, Pulst had not managed to send the objects to Tartu, because of the circumstances of war, and instead, he had travelled with them to Tallinn. There, he displayed the artefacts at the exhibition of the Estonian Agricultural Society (August 29 - September 1), under the title Estonian National Museum. The 1915 collection and antiquities from Tori, Pärnu County (Matto 1916: 18). The person who facilitated Pulst's participation at the display was Mihkel Aitsam, fiduciary of the ENM and an instructor at the Tallinn section of the Estonian Farmers' Society (Pulst 1948: 4).

I got to Tallinn before the opening of the exhibition of the Farmers' Society. I was given a space to display the Tori collection in the "rotunda" of the large pavilion. It was a big surprise-enormous interest in the antiquities from Tori. A lot of presents, a full set of a female funeral costume from Hiiu island, and other objects. Among those who approached me and introduced themselves were Hans Laipmann, veterinary K. Saral, lawyer Oldekop, journalist H. Prants and others. Approximately 30,000 people visited the exhibition within a couple of days. A contact was created with the people in Tallinn. (Pulst 1973: 8-9)

The popularity of antiquities at the exhibition provided an opportunity to display and introduce the objects for a longer period of time. August Pulst displayed some of the artefacts in an apartment at Vladimiri Street 24/4, Tallinn, and published a relevant announcement in the Päevaleht newspaper:

Who of us is not interested in our folk costumes and patterns! I thinkeveryone! But have we looked at them in detail, cast a glance to the depth and tastefulness of the mind of those who created these items? That's what it is - we haven't. This is why it is my wish and request: have a look at them once more. Examine them and do not disturb others doing the same. Let us know about the places where something similar can be found and make it possible to look at these "golden treasures" together. The foundation and organisation for all this is already there. (Pulst 1915a)

The apartment was in the ownership of the well-known esperantist of the time, Jakob Rosenberg, A. Pulst was a fellow tenant. The number of those visiting the display was around 50 and Pulst made copies of the patterns for those who wished them. Together with photographer Peeter Parikas, he arranged the photographing of the people dressed in collected folk costumes. In the later phase, Pulst tinted the photos and Parikas sold the pictures, however 
Pulst has subsequently admitted the inevitable inaccuracy of this undertaking (Pulst 1973: 9). The sets of folk costumes were not complete and in some occasions, even combined items from different localities.

This successful undertaking enthused August Pulst to promote the subject matter on a wider scale - a special issue of the magazine Tallinna Kaja was dedicated to antiquities and the promotion of the museum ${ }^{4}$, whereas the relevant information was mainly written by August Pulst himself. In addition, the magazine issue was illustrated with pictures of his collection trips and folk costumes, altogether 12 photos of garments, some of them taken during the collection trip and some photographed by P. Parikas. Pulst's magazine articles - being a very poetic panegyric to Estonian folk art - had a motto that education, culture and arts are the bearers of a nation (Pulst 1915b: 725-726).

\section{AN IDEA TO HAVE A SEPARATE DEPARTMENT}

Pulst, having graduated from the Art School in Riga, worked at the time as a decorator and stage painter at Estonia, the national opera and ballet theatre. His first job in the theatre was August Kitzberg's Werewolf, and he was deeply involved in the process. Pulst writes in his memories that in addition to the construction of props, he was also engaged in dress-making, setting the folk dance and teaching how to howl like a wolf:

I understood that there was a vital need here for different museum elements - you had to know how to apply them in action. It became extremely evident how the collections of antiquities of our nation are inevitably necessary for Tallinn in the creative work and that there was a great need for an Estonian museum. This is why I assumed the task to establish an Estonian museum here in Tallinn. And as it was hardly feasible, under the circumstances of war, to launch an independent museum in Tallinn, I became fully devoted to the idea to establish the Tallinn Department of the Estonian National Museum here. From that time onwards, I started with preliminary work in this direction. (Pulst 1948: 6)

A. Pulst's active involvement had indeed increased an interest in the museum. Bearing in mind this goal, Pulst and Rudolf Hurt, board member of the ENM, decided to ask those interested in the museum, i.e. the trustees and members of the ENM in Tallinn, to a meeting to discuss the relevant development activities in Tallinn. The meeting took place on 2 December 1915, in the premises of the Kindergarten Society, at Viruvärava Puiestee 23, and from among the 15 invited persons, the following people turned up: Rudolf Hurt, Mihkel Aitsam, 
Karl Saral, Aleksander Mohrfeldt, Ado Birk, August Busch, Nikolai Kõll, Hans Laipmann and August Pulst. The latter said in his speech:

Tallinn is not a village where we could collect the antiquities and move on. Tallinn is a city. There has to be a museum here, or a representation of the museum where to display the collections and to where the visitors would bring artefacts. I make a proposal to establish a Department of the Estonian National Museum in Tallinn! (Pulst 1948: 9)

Pulst's suggestion was adopted unanimously and he was given a mandate to pass the decision on to the ENM. On 13 January 1916, E. Eisenschmidt responded to the notice:

Decisions are indeed very good in case they are implemented. The supervisory board of the museum has not yet discussed the question regarding the Tallinn Department. Anyway, it is probably the full assembly of the Museum that will make this decision and commence with the relevant amendments of the statues. (Pulst 1973: 10)

Thus the idea of creating a separate department began to germinate.

Pursuant to the minutes of the ENM, the purport of Tallinn Department was first discussed at the board meeting on 23 January 1916 - a decision was made to propose the full assembly of active members with the following issue: c) when and how could it be possible to also open the departments of the ENM in other towns. (Suggested by Tallinn memebrs - A. Pulst) (Minutes II: 279). Next time, the relevant issue was discussed lengthily at the meeting of the board and the heads of working groups of the ENM, on 18 February 1916, between the convened Oskar Kallas, Karl Eduard Sööt, August Jõudu, Gustav Matto, Alma Johanson, Villem Ernits and Edgar Eisenschmidt. The minutes of the discussion report:

By now, after a relevant inquiry, we have received a more reliable notice from August Pulst about the establishment of the Tallinn Department of the E. N. Museum. Namely, the meeting of the Tallinn-based board members of the museum, trustees and heritage collectors was held on 2 December 1915, initiated by A. Pulst, and the decision was made: a) To start with large-scale systematic heritage collection in Tallinn, and for this purpose b) To obtain the permission of the local governor and military head. c) To establish the E. N. Museum in Tallinn and make a relevant proposal to the Museum government. d) To ask premises from the Town Government for the collection of antiquities or the future department, where to display artefacts for the public and organise exhibitions, e.g., on Old Tallinn and military weaponry. e) The artefacts collected in 
Tallinn would temporarily stay in the Tallinn Department. Having contemplated the proposal to establish the department, a decision was reached that Statutes of the [Estonian National] Museum do not allow to create an independent department, and moreover, the creation of such a department would fragment the power of the Museum, because it is important that we have at least one comprehensive Museum; still, we are of the opinion that local collection work could be largely inspired by local exhibitions of antiquities, which in some towns of our homeland could stay as permanent displays if local people wish to organise this and form into a specific working group for the collection of artefacts. (Minutes II: 281283)

As seen from the above, the issue of Tallinn Department was also an incentive to discuss the relevant problem more broadly, not only with the focus on either Tartu or Tallinn.

The highest governing body of the Estonian National Museum - the general assembly of members and active members - held a meeting on 19 February 1916, with more than 100 participants. Referring to the proposals made earlier in Tallinn and Viljandi, the following decisions were made during the gathering:

1) to instigate heritage collection at the local level, the Museum is ready to form local working groups; 2) the artefacts collected by the local working group are the possession of the Museum, however, they may be kept in the location of collection for some time as a permanent exhibition. The list of collected artefacts has to be sent to the Museum; 3) the Museum is ready to send doublets to permanent exhibitions, particularly of the objects that have been collected in the locality of the exhibition, likewise, the Museum would also set up the display of other artefacts in different places, should this be necessary; 4) it is recommendable, in places where there is a wish to set up a permanent exhibition, to raise money on the spot to cover the costs of collecting, and other expenses; if possible, the Museum would provide financial support for the organisation of exhibitions. It is not recommended to open independent departments as this would fragment the collections too much and complicate research. The opening of local exhibitions would hopefully bring in more new members. In Tallinn, there is hope to organise such an exhibition quite soon, steps have been taken to obtain relevant premises from the town government. (Minutes II: 291)

As becomes evident from the minutes, this meeting did not adopt an affirmative decision to establish the Tallinn Department, and the participants did not 
applaud this, as A. Pulst repeatedly refers to in his memoirs. The situation was quite the contrary.

As a response to the situation, on 19 March A. Pulst notified the joint meeting of the ENM board and the heritage collection working group, that several Tallinn-located members of the museum have suggested to convene a general assembly of the museum, bearing in mind that such a meeting in Tallinn would indeed be an impetus for the museum idea and make it more viable. As such a meeting would require proper preparation, it was thought that it was better to make an attempt to hold the gathering in autumn, and a relevant suggestion was proposed to the Tallinn members (Minutes II: 301-302). However, the general assembly did not take place in Tallinn in the autumn of 1916.

In reality, the museum-related activities in wartime Tallinn were mainly initiated by August Pulst. It was difficult to find rooms and if possible, some of the artefacts located in Tallinn were sent further to Tartu. The search for premises was still ongoing. In 1916, when Pulst worked in the Estonia Theatre as a decorator, he first placed the artefacts in his storeroom of paints. Pulst writes in his memoirs:

I took advantage of the situation - I de-cluttered the storage room of paints, it is a room without a window, with surface area of $1 \times 4$ metres, and I moved my Tori collection there, from Vladimiri Street 24. So, from a wooden house into a stone building. The artefacts remained there until the opening of the Museum Department in 1918. Thus, by the end of 1916, I had managed to send the majority of the Tori collection to the E. N. Museum, and, in addition, a lot of printed products from Tallinn. (Pulst 1973: 11)

Pulst's life and work in the Estonia Theatre also facilitated the collection of artefacts. In the rear of the theatre there was a market place in Tallinn, where rural people came to trade. For a heritage collector, this was a real goldmine. A. Pulst looked out of his window and when he spotted an exquisite blanket on a farmer's horse-wagon or sleigh, he would rush outside to make the bargain purchase. Pulst notes that he had actually learnt the trick - to exchange the antiquities of the farmers who had come to the town, for a new object or money - from Ants Laikmaa (Pulst 1948: 5).

In connection with the idea of creating a separate department, the number of the Tallinn-based members of the ENM increased from 83 to 166 during 1916 (Pulst 1973: 11), one of their tasks was to represent the ENM at the agricultural exhibitions in Tallinn. Museum artefacts from Tartu, and also contemporary handicraft made after old examples were sent from Tartu to be displayed at agricultural exhibitions, with a practical goal, in addition to the promotion of heritage - to find resources for the operation of the museum. 
The selling of heather branches was one of the main ways of procuring funds for the museum. It was quite by chance that the heather became the flower of the Estonian National Museum; due to practical reasons, it was necessary to find a beautiful and enduring plant that could be easily made into bunches and that would be in full blossom during fieldwork in the autumn. Likewise, it was also relevant that the flower would be easily available in large quantities. Young girls from upper secondary schools were the ones who mainly picked the heather and arranged it in nice bunches.

\section{ABOUT THE NECESSITY OF THE TALLINN DEPARTMENT}

The years of war and revolution passed relatively quietly and not much was undertaken in Tallinn. In addition to his engagement in the Estonia Theatre, August Pulst was also working as a full-time drawing teacher in the Lender High School for Girls, this leaving little time for museum affairs. As of autumn 1916, he became a conscript and worked in an office in Tallinn, while he continued painting props at night (Pulst 1973:12). Inevitably, the museum related work was put aside, apart from the collection of some printed materials from publishing houses.

Yet at the time, the feasibility and need for establishing a museum department was discussed in Tartu - on 11 February 1917, the general annual meeting of the ENM members and active members was convened, the minutes of the event reflect the following:

In order to promote and fecund the collections of the Museum outside Tartu, it is considered recommended to organise permanent and temporary exhibitions. It would be particularly necessary to open a permanent exhibition or department in Tallinn where the Museum collections, and their taking into practical life, would probably fall into good soil, for example, in the Arts and Crafts School. This issue has already been discussed earlier and considered to be recommendable. The meeting admits all these intentions to be necessary. During the negotiations, it is also recommended to promote the Museum activities, particularly in St. Petersburg. (Minutes II: 374)

August Pulst, a trustee of the ENM in Tallinn, took the floor during the abovementioned meeting, and announced that the town government of Tallinn was willing to provide premises for museum collections should there be a wish to establish a permanent exhibition in Tallinn. This idea, to open a permanent exhibition in Tallinn was unanimously approved by the meeting (Minutes II: 375-376). 
The ENM members from Tallinn and Tartu organised a joint event - an educational meeting conducted in Tallinn on 5 March 1917, where Kristjan Raud spoke about the crafts of English homes and Voldemar Päts focused on the craftwork of Estonian people. The Tartu-based ENM members were represented by spokesman E. Eisenschmidt (Minutes II: 358).

With an aim to enliven the relevant action, the Tallinn-based trustees and members of the ENM were convened in Tallinn, on 15 April 1918, by way of a letter signed by R. Hurt. The trustees were a separate link between the museum and people. This idea - to have local helpers for the museum - actually originated from the early days of the ENM. The meeting of the heritage collection working group had decided in 1909:

The immediate promoters of the Museum endeavour would be the trustees, requested by the Museum to do the job, scattered as densely as possible all over the country, not only in towns and in every parish but also in rural municipalities and villages. The trustees could be the people in charge of societies, teachers, doctors, chemists, merchants, rural municipality secretaries, etc. The responsibility of the trustees would be to accept donations and transfer these to the closest centres or, if possible, directly to the Museum. (Minutes I: 13)

By the end of 1917, the Estonian National Museum comprised 742 members, and, additionally, 99 life members. Out of the membership, 155 persons and 8 lifelong members were from Tallinn (Estonian National Museum 1918: 60-79).

Meetings were strictly forbidden at the time, relevant permissions were not granted. This might have partially been the reason why the number of participants was extremely small - the ones who came included Kr. Raud, Karl Saral, Hans Kubu, P. Parikas, Heino Vaks and A. Pulst. A decision was made to start the Tallinn Department of the ENM - the approval of the main museum had already been obtained in 1916 - and elect the board, appoint a secretary, rent the premises and immediately commence with the rescue and consolidation of artefacts and open the museum. Hereby a question emerges as to what was the basis for the firm knowledge that the relevant permission had already been granted by the Estonian National Museum, as the minutes of the 1916 meeting do not provide any confirmation in this regard. A. Pulst was appointed to be the secretary with monthly salary of 200 marks. As of September 1, Pulst's salary was increased to 250 marks, and Miss E. Bamberg was hired, at a pay of 1 mark per hour (Minutes 6/1918).

The election of the board was decided to be undertaken during the next meeting. As there were no premises available that could be suitable for the museum, A. Pulst conceded to rent out his studio, located in the concert hall 
side of the Estonia Theatre building, with the surface area of $50 \mathrm{~m}^{2}$ and monthly rental of 25 marks (Pulst 1973: 12-13).

The next meeting, held in the premises of the museum department, was also conducted secretly, without the permission of authorities. The convened participants were as follows: Ebba Saral, P. Parikas, Johannes Parikas, Jaan Rumma, Hans Kubu, Mrs. Anna Kõrv, Miss L. Kõrv, T. Jürgens, Ella Bamberg, E. Lass, Pauline Voolmann, A. Õunapuu, A. Pommer and A. Pulst. The members of the first board were elected: chairman Kr. Raud, secretary K. Saral, treasurer P. Parikas. Besides A. Pulst, Miss Bamberg was also employed. Candidate board members were Miss A. Kõrv and schoolteacher A. Saar. Director Jüri Jaakson and Dr. Aadu Lüüs were appointed as financial controllers (Estonian National Museum 1918: 59).

\section{LAUNCH OF THE DEPARTMENT}

The opening of the Tallinn Department took place on 12 May 1918. The museum was open every day for two hours (12-14). The indispensable fittings semi-glass cabinets - were obtained from the building society of the Estonia Theatre. Board members K. Saral and P. Parikas were present at the opening event, Kr. Raud was absent. The doors were opened and the first person to step in was A. Pulst. In addition, a number of people had gathered for the opening event. The door of the museum was decorated with two headings printed in two different languages on white cardboard: Eesti Rahva Museumi Tallinna Osakond ('Tallinn Department of the Estonian National Museum') and Estnisches National Museum Zveigstelle Reval (Pulst 1973: 13-14).

Soon after the opening of the Museum in the Estonia Theatre building, the procurement of new premises was taken into the agenda of the board meeting. An excerpt from the board meeting from 4 June 1918:

4) the issue of new premises was discussed, the possible sites came into question - - former premises of the catering service on Lai Street, the tower of Kik in de Kök and the premises of Kadriorg Palace. A decision was made to take steps to obtain them. (Minutes 5/1918)

This was the first time when Kadriorg Palace was mentioned in connection with the museum.

The news about the formation of the Tallinn Department and its activities was slow in getting to Tartu. It remains unclear whether this was to do with the complicated war time or mere unwillingness. It was only in June, at the board meeting of the Estonian National Museum when the secretary disclosed that 
some members and trustees of the Museum had convened in Tallinn and adopted a decision to establish a Museum Department in Tallinn to organise collection work and present the collections. It has been decided to appoint a paid secretary and obtain a room in the Estonia Theatre for record management and storage of collections. The idea was approved and it is recommended that the new department would firmly follow the decision made on 19 February 1916, at the general assembly meeting of the Museum, with regard to local working groups for the collection of artefacts and permanent exhibitions. A working group comprising A. Jõudu, Karl Eduard Sööt, J. Mägi and E. Eisenschmidt is elected to work out the relationship with the department and report their results to the general meeting. (Minutes II: 423-424)

The question concerning the financial relationship with the new Tallinn Department emerged in connection with the cash report. Money had been collected for the Tallinn Museum, and had been deposited in the Tallinn Loan and Savings Co-operative (approximately 15,000 roubles). It was decided to present the financial assets of the Tallinn Department in the consolidated financial report of the ENM, under a separate note (Minutes II: 419-420).

On 13 June 1918, the ENM presented the Rules of Procedure to the Tallinn Department, and the document was adopted on the next day, at the general meeting of members and active members. The Rules of Procedure stipulated the following:

1) Estonian National Museum shall establish the Tallinn Department with the purpose to supplement and present the collections of the museum.

2) The collections and the inventory or the Department shall be in the ownership of the Estonian National Museum.

3) To accomplish its tasks, the Department shall be entitled to organise collections, exhibitions, parties, etc. and receive donations in the name of the Museum.

4) The collections of heritage (i.e. folkloristic and cultural history related) shall remain in Tallinn as a permanent exhibition, for a shorter or longer period of time, upon the agreement of the board of the Museum. Collected artefacts shall be registered in Tartu, within the general list of the Museum, with an additional list of records held with regard to the artefacts in Tallinn.

5) 1-2 copies of all printed materials - books, newspapers and archival materials - obtained by way of the Department shall be given to the archival library located in Tartu at the Museum.

6) The Museum shall give its doublets to the Department and, if so requested, shall organise temporary systematic exhibitions of its other collections. 
7) The members of the board and the internal audit committee of the Department shall be elected at the general assembly of the members of the Tallinn Department, of which the E. N. Museum shall be notified. The chairman of the board of the Department is simultaneously the Museum's representative in Tallinn.

8) The Department shall have its own business records, the list of collections, inventory records, cash book, minutes' book, and a record book for the copies of incoming and outgoing letters.

9) The officials of the Department, and if requisite, also the paid officials, shall be invited and elected by the board of the Department.

10) The Department shall operate within the limits of the budget, approved by the general assembly of the Tallinn members, of which the E. N. Museum shall be notified (approve).

11) The board of the Museum shall be entitled to inspect the operation of the Department at any moment of time. The Department, on the other hand, shall annually send its activity reports.

12) The decision with regard to the dissolution of the Department shall be made by the general assembly of the Department by a simple majority vote. (Rules of Procedure)

As becomes evident from the Rules of Procedure, the Tallinn Department actually enjoyed relatively substantial independence in organising its activities, and the Estonian National Museum in Tartu did not consider it necessary to interfere in the issues regarding the management and administration of work. The fact that the collections and the archive form an integral whole is a normal situation in the relationships with the mother institution and a department.

The work and activities of the department were diverse, endeavouring to involve young people. A. Pulst with his inexhaustible museum enthusiasm managed to indeed inspire the young. Thus, a youth circle gathered around the department, altogether seven persons who referred to themselves as museumlased ('museumians'), they all had personal nicknames, for instance, Muuseumieesel ('Museum Donkey), Paberikoi ('Paper Worm'), etc. August Pulst was called Vanamuuseum ('Old Museum') or simply Museum. The young museum friends walked around and collected antiquities, having collection books with them to precisely note down all the artefacts. This fact was also announced in the newspaper:

The collectors of antiquities, dispatched by the museum department, have museum-named collection books with them. Those who do not have this, have nothing to do with the museum department. (Päevaleht 22 Nov 1918) 
German occupation started in February 1918, followed by the destruction of all kinds of revolutionary literature. The Estonian National Museum attempted to collect the material associated with the revolution. An order was issued in Tartu to commence with the rescue of revolution related materials - all kinds of printed matter were collected, such as fliers, etc. In Tallinn, for instance, an attic was cleared of Bolshevik literature. On Thursday nights, the young museumians gathered at A. Pulst's place, around a red-light electric bulb to tell ancient stories - this was the reward for their collection work (Pulst 1973: 14). All these undertakings did involve a great deal of risk at the time, and could not be allowed according to today's museum education principles. Still, A. Pulst and actor H. Vaks were indeed the two main figures involved in this risky undertaking, rescuing revolutionary materials from incineration in central heating furnaces. The relevant results were extremely good, according to a report of $1918^{5}$ (Activity report). The museum department also established an archival library in Tallinn, upon the initiative and efforts of a young enthusiast J. Tohvelman. By the time the Tallinn Department of the ENM concluded this operation, more than 1000 books and 300 brochures had been collected (Pulst 1973: 18). However, this endeavour had probably not been too consistent as in 1919, the board meeting had decided:

to consider it necessary to establish an archival library at the Museum Department, to collect everything that is published in the Estonian language, and secondly, all literature that concerns Estonians and Estonia, and what has been published in foreign languages in our country. (Minutes 20/1919)

During the next meeting, it was understood that all this could not be accomplished at once, and a principle was introduced: to primarily acquire books which are endangered to become lost and are rare, and the second type are fiction books, and the third type are books of little importance. (Minutes 22/ 1919) The fact as to what kind of books are of little importance, and why, is not further explained.

An important direction in the operation of the museum was to render more wide-based value to heritage. A. Pulst, together with Karel Kitt, a young eager member, organised a museum day in Harku, in the vicinity of Tallinn. Before the event, 317 artefacts had been collected in the vicinity, and at the end of the day, the best collectors were awarded prizes, accompanied with the orchestra. However, it is not known whether these objects were later received in the Estonian National Museum. Still, this event undoubtedly increased the awareness of people with regard to the value of antiquities. 
This was also the outset of the tradition of museum parties, aimed at introducing the work directions of the museum to the wider public. The first party, with a concert, dancing, lottery, sign-selling and other entertaining activities was organised by the Tallinn Department in the Estonia Theatre concert hall on 23 November 1918. The party was dedicated to the departure of the German occupying forces.

Now, when the dawn of our freedom is glimmering again, when every eye, be it young or old, is sparkling with hopes towards the future, now we also have to take care of our cultural institutions with all our efforts and eagerness. The Tallinn Department of the E. N. Museum, pushed into narrow frames because of external circumstances, as if pushed against the wall, is now intending to become a large and wide-based people's museum that could not only be recommended for the inhabitants of Tallinn, but also to neighbours and other nations. This is why the board of the museum department appeals to everyone with a request: do support the museum enterprise! (Päevaleht 22 Nov 1918)

In the same newspaper, the museum also presents its political manifest:

Our museum is people's museum and thus is open to all. The Museum stands aloof from all kind of politics and party activities, being thus on totally unbiased ground. This is why we dare to appeal to everyone with the request - to contribute to the museum undertakings as much as you can, according to your capabilities. Let us utilise our freedom to primarily fulfil our duty with regard to the museum! (Päevaleht 22 Nov 1918)

Buoyant efforts were made to procure larger premises for the museum. As one of the options, the possibility of using Kadriorg Palace was again discussed in the agenda, as evidenced in the minutes of the ENM Tallinn Department of 28 November 1918, at the meeting held in the brothers Parikas' place: With regard to the department's apartment, a decision is made to apply to the local town government, bearing in mind the Kadriorg Palace. (Minutes 15/1918)

At the end of the year, however, the museum was hit by burglars - the activities of the museum must have been too conspicuous, and confusing times are always a good season for smaller and larger crimes and thieves. A wooden box had been broken open in the museum corridor, and 1,331 postcards, recently sent from Leipzig, had all been taken. Some of these postcards, titled Jägala kosk Jõelähtmes ('Jägala waterfall in Jõelähtme') and Sõrulased rukist ossumas ('Sõru people harvesting rye'), were obtained back later - the police had caught two young boys with 420 postcards, and a Defence League member, Reikop, had bought 171 at the flea-market, paying one mark per a hundred 
cards. ${ }^{6}$ The museum was broken into on the night of 8 December, padlocks were broken, the doors tampered with and the drawers forced open. The loss was 308 marks and 60 pence of the money raised with the lottery, and the money for the postcards of Tartu, altogether 100 marks, and the silver coins of the parish court from 1828, the personal property of secretary A. Pulst (Minutes 16/1918).

After the end of the German occupation, the museum decided to immediately start collecting any war related material for the relevant military department. Negotiations commenced with the Supplies Management of the Estonian Army (Minutes 16/1918). Things went smoothly and during the first board meeting of 1919 , it was decided to:

assume the task of organising the Museum of the War of Independence, proposed by colonel Soots, chief of the operational staff. As the first stage, to open a military section at the ENM Tallinn Department. (Minutes 1/ 1919)

Information about this decision spread fast, particularly among the military, and a number of soldiers' associations expressed their will to organise fundraising parties for the benefit of the museum (Minutes 11/1919 \& Minutes 13/1919).

\section{CONCLUSION OF THE FIRST YEAR OF OPERATION}

The first year of activity of the Tallinn Department of the Estonian National Museum was summarised during the first general assembly meeting of 1919. In his speech, Kristjan Raud underlined the circumstances and conditions the museum department had to operate under during the first year, and revealed the plans for the future:

The Museum Department has fortunately survived the difficulties of the German occupation, although the times were a substantial obstacle for the work and activity of the museum. At present, being protected by the government of free Estonia, and taking the position of being entitled to support, the Museum Department hopes to continue, more fruitfully, with the rescue of our heritage. The tower of Kik in di Kök has been chosen as more spacious and appropriate premises - and hopefully these rooms will be obtained for our disposal. The membership of the museum had significantly grown in Tallinn. (Protokoll I)

In 1915, the membership of the Tallinn Museum was 61; on 12 May 1918 - 191 persons and on 1 January 1919 - 379. The number of visitors in 1918 was 855 . 
Four parties were held for the benefit of the Museum Department: in Haapsalu, Hageri, Harku and Tallinn, the latter, being the most successful one, was organised by the Museum Department itself. Money was raised from parties, donations, membership fees and the sales of printed matter. With regard to the future, plans were made to supplement the existing collections with those of natural sciences. Yet as the first step, attempts were made to complete the collection of tangible heritage ${ }^{7}$ (Protokoll I). Still, there was probably no clear and explicit understanding as to when to consider a heritage collection completed and heave a sigh of relief. During the meeting, certain misunderstandings could be noted between the Tallinn Department, and E. Eisenschmidt, the representative of the ENM. The Rules of Procedure, devised by the Tallinn Department pursuant to the procedural rules adopted on 14 June 1918, were discussed during the meeting. Namely, K. Saral made a proposal that the ENM could allocate a subsidy for the Tallinn Department to purchase antiquities. The current Rules of Procedure had not provided for this issue. Eisenschmidt claimed that in the name of the ENM, he was not entitled to promise any financial support for Tallinn. Saral and Raud were of the opinion that a certain annual support sum should indeed be agreed upon, to be granted to the Tallinn Department on a yearly basis. The question remained unresolved, although a decision was made to add 10,000 marks, as expenditure, to the budget, hoping to receive this from the Estonian National Museum. The Tallinn Department felt too oppressed by the ENM, there were misunderstandings with regard to the number of board members, and a protest against the fact that the Tallinn Department should organise separate collections, exhibitions, parties, etc. only upon the relevant agreement of the Estonian National Museum. K. Saral claimed that pursuant to clause 7 of the Rules of Procedure, Kr. Raud was also the representative of the ENM in Tallinn, and thus free to approve any undertaken activities. Kr. Raud, on the other hand, expressed an opinion that if they had to ask for permission from the ENM for any minor activity, this would definitely impede the operation and undertakings of the Tallinn Department, and if this is not done, it would mean the violation of rules. In addition, the distribution of collection regions was one of the reasons for disagreement. Eisenschmidt's suggestion to be limited merely to the vicinity of Tallinn was not approved. Although this was to do with the one and the same Estonian National Museum, competition was clearly discernible when dividing the lines of force. Tartu people reproached Tallinn for collecting antiquities in Pärnu area, this accusation was countered by the Tallinn Department, noting that the Pärnu region had been totally neglected by the museum. Similarly, differences of opinion were also in the air with regard to the entrance fee. Tallinn wished to introduce a fixed sum, yet Eisenschmidt was firmly convinced that 
this would be inappropriate for the museum, and that voluntary donations would bring in more money that a fixed charge. Thus, the first dissent between Tartu and Tallinn was clearly visible (Protokoll I).

During the board meeting in May, held at the brothers Parikas', separatist moods did not yet prevail, although there were problems with self-discipline, and a decision was made to react to this:

Members of the board who are more than five minutes late to the meeting, and also those who are absent from the meeting without prior notice or reasonable excuse, shall be fined with 3 marks to go to the revenue of the Museum. (Minutes 10/1919)

Again and again, the premises remained to be the main concern. After long and complicated negotiations to rent the rooms in Kiek in de Kök tower, the idea was finally given up due to the smallness of the premises and expensive refurbishing that needed to have been done. With an aim to have new, more appropriate rooms, it was decided to gather more data about the Üxküll House at Toompea Hill, Tallinn Club and the Guild Hall at Pikk Street (Minutes 5/ 1919). Still, the palace in Kadriorg continued to be the best possible option (Minutes 18/1919).

\section{TOWARDS BECOMING AN INDEPENDENT MUSEUM}

For the first time, independence was discussed at the board meeting of the Tallinn Department on 5 July 1919, in the Ministry of Education, with the presence of Kr. Raud, K. Jürgenson, P. Parikas and A. Pulst, bearing in mind the great plans for future:

It is admitted to be necessary to explain the Museum idea at teacher training courses, to get local forces to work for the Museum, to arrange parties for the benefit of the Museum, to hire permanent - with a fixed salary-collectors and organise local exhibitions of collected antiquities; to give detailed suggestions and instructions in newspapers for collectors, and to publish lengthier campaigning articles in all newspapers in order to encourage collection. (Minutes 16/1919)

Likewise, the issue concerning the heritage collection was prioritised also at the next board meeting, dedicated solely to this aim, and a decision was adopted to start sending pairs of schoolchildren and social figures on collection trips. The areas chosen for this work comprised the vicinity of Haapsalu and the islands, as the losses of antiquities in these regions were most substantial, due 
to holiday-makers and buyers. For instance, the collectors on Muhu island had noted that the local people would not sell woollen garments for money, at any condition, however, they would exchange these clothes with purchasers and dealers for different haberdashery goods -

this way, one purchaser had collected 200 pairs of mittens, with an intention to un-weave them and have them knitted as new market goods. As there is no other good way out, the board is also going to switch to the exchange of goods. The total of 1,500 marks of credit is allowed in order to purchase a certain amount of goods to be exchanged. (Minutes 28/ 1919)

When discussing the issue of an independent museum, consideration was given to the fact as to what kind of impetus and freshness could the launch of the new museum bring about for collection endeavours, and whether a new independent museum could be an impediment in having complete ethnological collections in Tartu (Minutes 17/1919). Collection activities in Tartu had come to a standstill, and this was the main argument for Kr. Raud why the Tallinn Department should become a separate and independent museum.

One of the ideas, with an immediate impact on the work of the Tallinn Department, was the establishment of an open-air museum. In his memoirs, August Pulst writes that he had made a proposal to the board, at the very beginning of its operation, to launch an open-air museum. Together with $\mathrm{Kr}$. Raud, they had visited the Seurasaari Open-Air Museum in Finland in 1916, and this had left a wonderful impression on them. With T. Künnapuu, his schoolmate, they had found a suitable plot at the River Pirita, in Lükati. Pulst, arguing in favour of his proposal, stated that the Estonian National Museum in Tartu had been actively involved in searching for possibilities for an openair museum, but Tallinn was a much larger city than Tartu! (Pulst 1973: 16) Thus, at the board meeting on 5 July 1919, a decision was made to establish such a museum. An outing-trip was arranged at the beginning of September to find a suitable location, the relevant committee comprised Kr. Raud, K. Jürgenson, Paul Raud, Dr. A. Lüüs, instructor Johanson, A. Tabbur and A. Pulst. The first stop was in Kose forest (Koch Park), on the left bank of the River Pirita, to have a look at the surroundings, up to approx. half a mile upstream from the river-mouth. The impression was indeed very positive. The second potential site, 7 miles away from Tallinn, was near Lükati, ca 1.5 miles inland towards the seashore. The conclusion was as follows:

When comparing Lükati and Kose areas, the committee considers the former to be much more appropriate, and bearing in mind the plans of the local town government, to build a zoo and a sanatorium in Lükati, 
which would assumedly mean that there will be an electric railway connection with this area, the committee puts the Lükati area in first place, as a location for an open-ait museum. The final decision will not be made until all the potentially suitable locations in the vicinity of Tallinn have been studied. (Minutes 23/1919)

The next outing to find a proper place for the open-air museum was proposed by architect K. Burmann, and headed to Haabersti and Rocca al Mare, together with Kr. Raud, J. Lintrop, A. Laikmaa, K. Burmann and A. Pulst. The trip was high-spirited, and as a result, the committee adopted a decision to consider the particular location appropriate for the establishment of an openair museum (Minutes 26/1919).

The idea of an independent museum in Tallinn was continuously growing. In the autumn of 1919, plans for future were discussed at several board meetings in Tallinn, where the thought of an independent museum was repeatedly reverberated. There was also an option in the agenda of a central museum to be located in Tallinn, with departments in all towns (Minutes 24 \& 25/1919). During the discussion on 4 October, Karl Jürgenson highlighted the following points in regarding this plan: 1) it is easier to do promotion in Tallinn; 2) the new society would bring in new material; 3 ) with its museum department, Tallinn is as if of a second category; 4) negotiations with Tartu are an impediment in carrying the things forward. Still, Jürgenson admitted that the preparatory potential was better in Tartu, due to the university, and there were no properly qualified personnel in Tallinn. ${ }^{8}$ (Minutes 25/1919) Long and passionate discussions were held, mainly whether to form one large or several small museums, whereas the aim of the museum was primarily seen as heritage collection, and proceeding from this - which of the two variants would facilitate the collection of more antiquities in all parts of Estonia - in Setomaa in the south-east and Saaremaa island in the west. According to Kr. Raud, the 10 years of operation of the Estonian National Museum had actually been a relatively long period for the museum to become outdated - it is important to rescue the antiquities, making gigantic efforts in this regard. P. Parikas continued to be in favour of having several museums, and said that the main drawback of the Tartu museum was the fact that the communication between board members was complicated as the latter were scattered in a number of different towns. A. Pulst, on the other hand, fervently opposed the idea of having the state in charge of the organisation of heritage collection:

If the government steps ahead, the people would pull off their hands... In Pärnu area, people were a fraid of showing old things, thinking these would be registered and taken away later on. The parson in Mihkli did not want 
give permission to the representative of the museum to look around in the church, for the same reasons, and said that the government could also confiscate the properties of the church, and it is therefore necessary to be cautious. (Minutes 25/1919)

K. Jürgenson, holding a totally different standpoint, claimed that a museum of a social circle is a cottar's museum, and money is the basis of everything. If the government gives money for the collection of artefacts, everything will be collected. H. Vaks proposed that all museums should be convened under a uniform central organisation which would then make proposals to the government, as in the case of the Association of Estonian Actors. This central organisation would also be competent to place and locate individual collections; or in other words, to establish an independent museum in the capital, disregarding everyone. K. Jürgenson was most adamant in demanding to devise a collection plan with the help of the government: to set up a collection working group, organise training courses for collectors, apply for credit and appoint a consulting representative at the Ministry of Education. ${ }^{9}$ A resolution was adopted wherein clause 1 states as follows:

a) As there is no Estonian Museum or a relevant society in Tallinn that could bring this into life, and as the operation of the Tallinn Department of the E. N. Museum (heritage collection working group) is too limited for the foundation of such [an institution], the board of the Museum Department shall consider it appropriate to establish an independent museum in Tallinn.

b) In principle, the board shall confirm that the central museum be founded in Tallinn, departments shall be launched in county towns, where there is no museum yet, bearing in mind the rapid loss of antiquities and urgent need to rescue these, and

d) The board is of the opinion that governmental support to the functioning of museums is strenuously needed, both with regard to material support, and also to maintain an expedient balance between individual museums of Estonia. (Minutes 25/1919)

The extraordinary meeting of the Tallinn Department, on 14 November 1919, adopted the resolution:

The capital demands an independent museum for comprehensive presentation of the land and people. At the same time, there is also a need in Estonia for another type of large-scale museum that would enable the investigation of the domains that have been more left aside in the operation of the Estonian National Museum. It would be impossible in the 
future to widen the scope of the museum in Tallinn, as the Department of the Estonian National Museum, bearing in mind the impeding dependence of the Department from Tartu. For this reason, the meeting has decided to [...] terminate the operation of the E.N.M's Tallinn Department. (Minutes 30/1919)

The former collections of the Tallinn Department of the Estonian National Museum were stored in the Estonian Museum Society, and remained in the ownership of the Estonian National Museum. The liquidation committee comprised August Pulst and Bernhard Linde (Minutes 30/1919).

With an aim to establish the Estonian Museum in Tallinn, eight preliminary meetings were held from 5 October to 9 November 1919, participated in by Kr. Raud, K. Jürgenson, A. Thomson, P. Parikas, H. Vaks, A. Pulst and J. Vestholm. The statutes of the Estonian Museum Society were devised and legally registered in the Tallinn-Haapsalu Peace Court on 7 November 1919. The aim of the Society was to establish and maintain the Estonian Museum in Tallinn. The purpose of the Estonian Museum was to promote the knowledge of Estonian people and the country, by way of cultural-history, ethnographic and natural science collections. The more immediate task was to rescue heritage all across the country, with a relevant budget of 940,000 marks, with 15 collectors and 10,000 artefacts.

The opening meeting of the new Estonian Museum Society took place on 17 November; in the beginning, there were 23 members of whom Kr. Raud, K. Jürgenson, P. Parikas, A. Thomson and A. Pulst were elected as board members. Indeed, 17th of November 1919 is considered the commencement of the Society and the Estonian Museum.

Raud, Jürgenson and Pulst, the members elected at this general meeting, announced in Tartu, on 30 November, at the general meeting of the Estonian National Museum, that they had established a new museum in Tallinn, the "Estonian Museum in Tallinn", and suspended the operation of the Tallinn Department of the E.N. Museum. Should the E. N. Museum wish so, they can continue with the work of the department. The representative of Tallinn disclosed that the new museum - Estonian Museum in Tallinn, has set up a plan to collect heritage all over the country. The E.N. Museum responds that they would like to take part in this. (Pulst 1973: 21)

The meeting to settle the relationships between the museums took place on 3 January 1920, with the presence of E. Eisenschmidt and Gustav Matto on behalf of the ENM, and Kr. Raud and K. Jürgenson from the Estonian Museum in Tallinn. Following lengthy discussions as to what would remain in Tartu 
and what in Tallinn, the atmosphere being oppositional, with no hint of friendly cooperation, it was finally decided:

1. ...The Estonian Museum Society in Tallinn shall give the more rare objects of its ethnological and archaeological collections to the Estonian National Museum, to supplement their collections, and shall receive doublets from them.

2. The Tallinn Department of the E.N.M shall be terminated pursuant to the decision made by the general assembly of the E.N. Museum and its active members on 30 Nov 1919.

3. All the collections and property gathered at the Tallinn Department of the E.N.M, until the day of liquidation, shall be in the ownership of the E.N. Museum.

4. From these collections and property, the E.N. Museum shall give the Tallinn Museum Society [the right to]:

a) use of the fittings of the department;

b) for permanent storage, the collections that have been given to the department on condition that these would stay in Tallinn, and doublets from other collections.

5. The E.N. Museum shall agree to leave the government subsidy (72,500 marks) to the T.E. Museum Society, upon relevant possibilities. Otherwise, the department shall utilise the money to purchase things which, as the property of the E.N. Museum, shall be left with the Tl. E. Museum.

6. The objects of private persons and institutions, stored at the Department of the E.N. Museum, shall be kept at the Tl. E.M. Society under the same conditions. (Pulst 1973: 21-22)

Thus, the collection endeavours commenced vigorously in 1920, and courses on the collection of tangible heritage were organised, $\mathrm{Kr}$. Raud lectured on theory, Karl Burman on Estonian buildings, Matthias Johann Eisen introduced the collection of verbal and linguistic heritage, Peeter Süda focused on the collection of folk tunes, and Peeter Parikas on photography. At the end of the course, there was a demonstration of antiquities and a trip to the ENM, followed by practical work in town and countryside (Course programme). In 1920, the Ministry of Education began to contribute to collection activities, and arranged the countrywide rescue days of antiquities on the 9 th and 10th of May, when teachers and students of rural schools were obliged to go and collect ethnographic and cultural history related heritage for museums, and not be involved in studying. There were 34 paid collectors in 1920, their number decreased as of 1922 and reduced to none in 1924 (Paas 2004). 


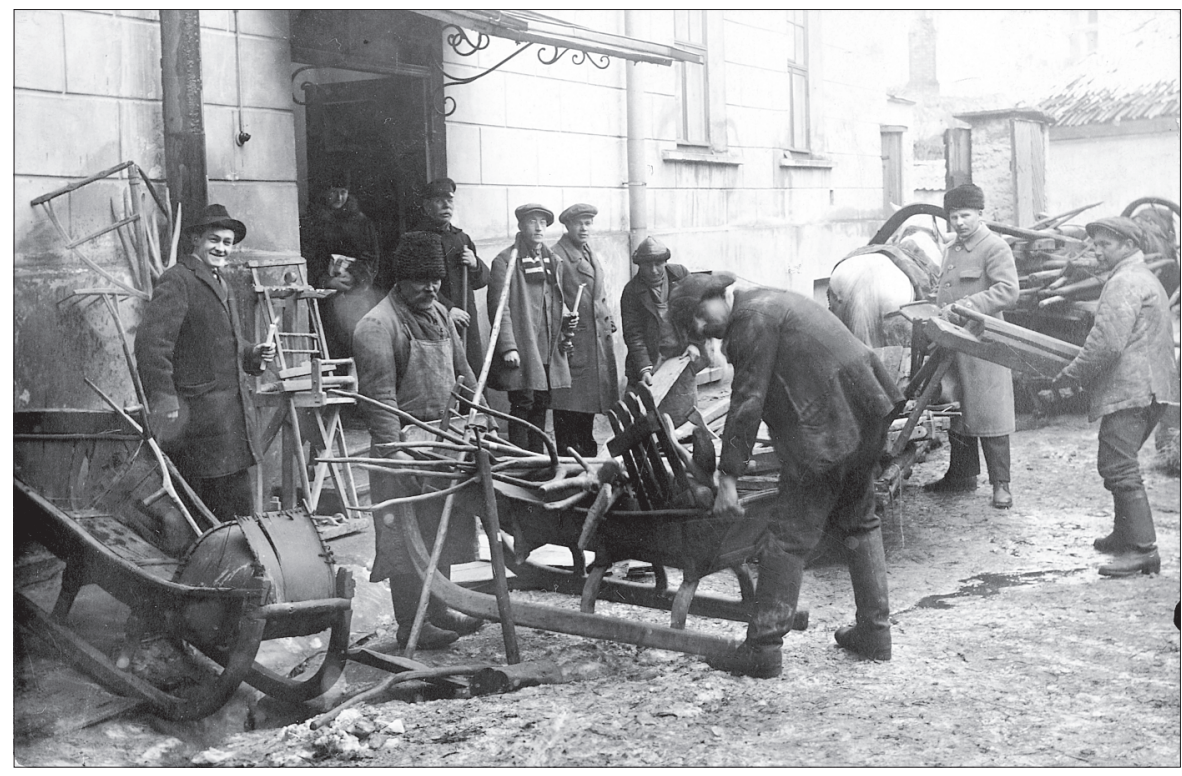

Figure 2. The Estonian Museum in Tallinn moving from the former Knighthood House on Toompea Hill to the Kadriorg Palace (from the yard) 1921. Second from the left: August Pulst. ERM Fk 1706:21. Photo by Johan Wildt.

Expanding collections again exacerbated the issue regarding insufficient space. The rooms at the disposal of the museum in the Estonia Theatre building, and the coat of arms hall in the Knighthood House could not accommodate the large amount of artefacts, let alone display them. Thus, the museum appealed to the Ministry of Education to obtain the right to use the Kadriorg Palace. However, the ministry was also interested in the palace; the building, ravished in war, was at the time being laid out for the national art museum. As the Ministry of Education's collection of Estonian art, applied art and styled furniture was still small, $\mathrm{Kr}$. Raud who worked at the time in the ministry, in the department of art and antiquities, made a proposal to give the entire palace to the art museum, and while they were not yet able to fill all the rooms, to allow the Estonian Museum in Tallinn to set up its collections there. The government of the Republic of Estonia approved this proposal (Paas 2004).

When establishing the museum in Tallinn, the intention was to go along exactly the same path as the Estonian National Museum in Tartu, and to continue with what had already been done earlier, as the department of the ENM. This was a situation where there were two parallel ethnographic museums operating in Estonia, and no museum of fine arts whatsoever. 


\section{CHANGE OF DIRECTION}

The moving of the museum to Kadriorg Palace was a step forward in the change of course. In 1919, August Weizenberg, the sculptor, who had returned to his homeland to spend his retirement days, had been granted permission from the Construction Board, the then owner of the Kadriorg Palace, to place his figures, and the ones he had sold to the town, in the palace (Paas 2004). The Estonian Museum in Tallinn had managed to procure quite a few works of art, imported from Russia, a substantial addition to the museum's art collections (Linde 1931: 10). Gradually, the collections of the museum increased because of the many heritage collectors who brought back, from their expeditions, the objects and artefacts that had belonged to churches and manors. The festive opening of the museum in the Kadriorg Palace took place on 10 September 1921, during the agricultural exhibition. When the exhibition ended, the Estonian Museum also closed its doors, and persons involved began to expand the display and prepare the work in a better well-thought out manner.

At the same time, impetuous heritage collection continued, with an intention to complete this in 1921. The task force for the rescue of Estonian heritage finished its work on 21 April 1921, but the collection was continued directly under the auspices of the Estonian Museum in Tallinn (Pulst 1973: 4142). In addition to the collection of ethnographic artefacts, attempts were made to find opportunities to establish an open-air museum. Unfortunately, there were several unsuccessful endeavours to obtain land from the town government, whereas the artefacts in the country had already been selected for removal, among them the old wooden church on Ruhnu island. August Pulst went to conclude a deal with the islanders, having previously received the Ruhnu inhabitants in Tallinn and showing them around. As a reward, he was welcomed on Ruhnu as a friend. The islanders agreed to transfer the church, built in 1644, to the museum, they even consented to break it down, take it to the shore and load it on the ship, but in return they wanted an organ for the new church, at an approximate price of 70,000 marks. From this trip, Pulst brought back nearly 200 artefacts, mainly meant to furnish the "Ruhnu room" in the museum (Postimees 25 Aug 1921).

The tradition of museum parties was maintained, upon the initiative of A. Pulst whose interest in folk music was a great connecting element between people and merrymaking festivities. He had been involved in amateur theatremaking during his collection expeditions for the Estonian National Museum. At that time, there were no strict rules for handling museum objects, and people were happy to put on the collected folk costumes and play theatrically to entertain themselves and the others. Pulst writes in his memoirs about a festivity in Raiküla in 1920: 
The hall was filled with spectators, explanations given by the collector and myself. In the same community house, the party room was filled to the brim. In the programme: songs by the mixed choir of Raiküla and a play. (Pulst 1973: 31-32)

No doubt, these events were profitable, making the public aware of the value of heritage and the essence of the museum.

The museum was continuously expanding - in January 1922, a memorial room for Peeter Süda was opened, furbished with the possessions of the composer, donated by the heirs (Paas 2004).

In 1924, the museum continued to grow, with a focus on the collection of folk dances, folk games and relevant music. In the same year there was a significant impetus for the museum, to open the department of fine arts in an accelerated manner: the Ministry of Education and the Tallinn Town Government deposited a large collection of newer Estonian art, to be stored and displayed in the museum (Linde 1931: 13).

1925 was pivotal for the museum with regard to the change of course earlier diffusion and the creation of new departments, i.e. fragmentation was replaced with consolidation and focusing, by putting two domains in the forefront: the department of fine arts and the collections of cultural history related heritage, as the ones deserving most attention, were arranged for display (Linde 1931: 13).

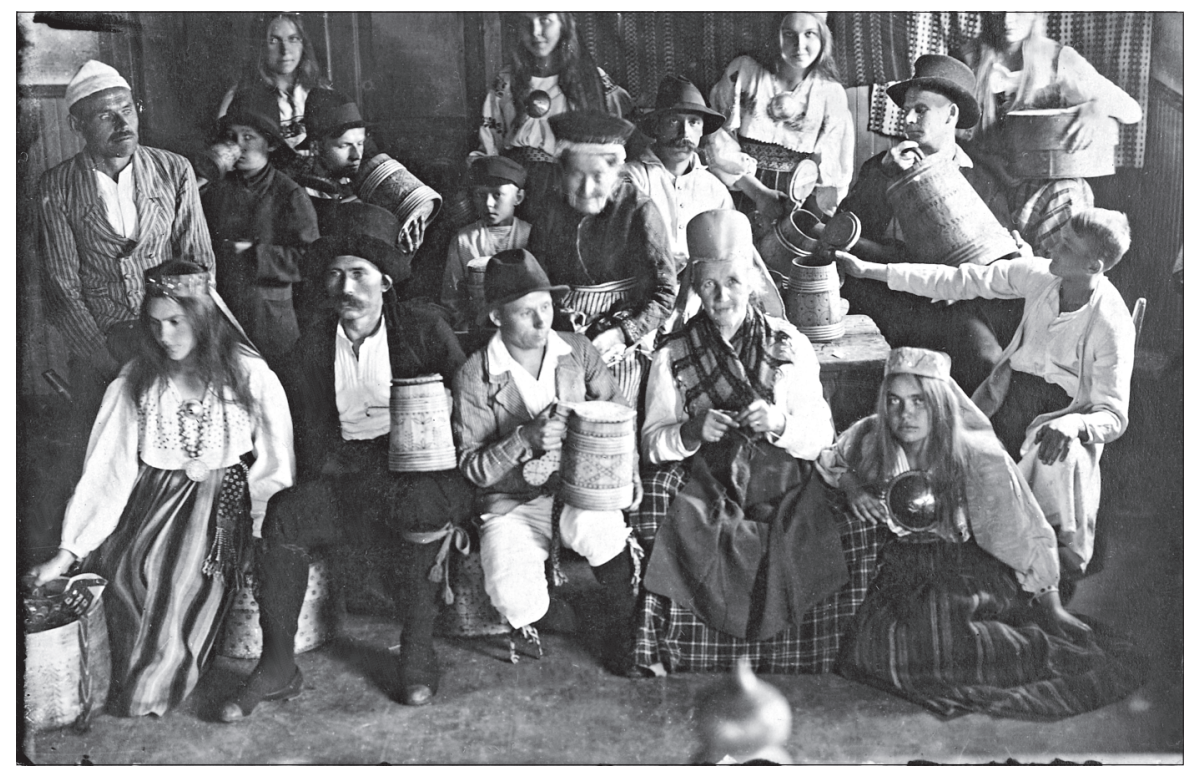

Figure 3. Participants in the Raiküla party, arranged by the Estonian Museum in Tallinn. 1920. ERM Fk 1706:18. Photo: unknown. 
Still, the existence of two similar museums, in Tartu and in Tallinn, was senseless for a small country, and the formation of an art museum was of great significance for a nation state. Thus the relevant step was in every way a logical result of earlier developments.

Nearly the whole of the homeland had by now been covered with collection trips, and thus the five-years-long operation of the Estonian Museum in Tallinn has come to an end. Should there still be two museums working adjacently in Tallinn and Tartu, both mainly the collectors and keepers of ethnographic objects? Considering the small size of our homeland, such a superfluity would be clear for even a casual observer. Thus, gradually a standpoint was reached that the Tartu-based Estonian National Museum should be ethnographic and the museum in Tallinn - an art museum. (Linde 1931: 14)

From today's viewpoint, it is weird and even comical as to how certain limits were set for having collected the heritage. Yet at the time, there was some truth in this as large-scale collections had been completed and the collections of both museums had been continuously growing. The line had to be drawn somewhere. Increased costs related to ethnographic collections were undoubtedly another considerable reason for such a standpoint.

The process of how the Estonian Museum in Tallinn gradually evolved, from an ethnographic museum to an art museum, can be observed on the basis of published catalogues. When comparing the years 1922 and 1923, art collection had obtained an additional room; in 1927, the folk art department displayed a representative exhibition (Estonian Museum in Tallinn 1922; Estonian Museum in Tallinn 1923; Tallinn Museum 1927).

Following lengthy discussions, there was the moment, on 22 November, when the extraordinary general assembly of the Estonian Museum Society in Tallinn decided to amend the statues and develop the Estonian Museum into an art museum (Paas 2004). With this, the change of direction was completed and the development of the art museum commenced.

Estonian artists and intellectuals had been striving for an art museum for a number of years. However, this plan had receded into the background due to the powerful performance of the Estonian National Museum, and the goals and purpose of the ENM had been more explicit and understandable for the wider public. Rendering value to ethnic nationality, history and folk culture this was an undisputable domain. The discussions, whether the Estonian National Museum should collect Estonian art did take place as early as during the foundation meeting of the ENM, however, these disputes were finally overshadowed by antiquities and the library. At the time, Jaan Tõnisson was the 
person who stood up for art collections. The issue concerning art was explicitly raised in connection with the III Exhibition of Estonian Art in 1910. In the promotion address of the exhibition, Tõnisson writes, among other matters:

On their behalf, the authorised working group expresses the idea to purchase works of art, for pure profit, for the Estonian National Museum in Tartu and for the Museum of Art to be established in Tallinn. Should this application by the working group be accepted, it will be the jury of the art exhibition who will decide as to what works to buy. (Promotion address 1910)

In reality, due to the more than limited financial circumstances, it was even impossible to think, more seriously, about a separate museum for Estonian art. Instead, the only option to be considered was to establish a department of fine arts at the Estonian National Museum. This was indeed the platform taken by the artists involved in Noor-Eesti (literally: Young Estonia), the cultural movement of the young intelligentsia, and by those interested in art; they also decided to demand, from the leading forces of the Estonian National Museum, to be given some independence at the department of fine arts formed in the ethnographic museum (Linde 1931: 6-7).

The possibilities to collect art were discussed at the beginning of 1911 , during the meeting convening active members and the board. According to Oskar Kallas, there were no financial resources at their disposal to purchase art, at least in the beginning, as the only revenue of the ENM Society were membership fees and donations, used solely for obtaining antiquities. The collection of works of art would have been possible only in the form of donations and deposits. Likewise, it was important to display art and give the artists a much needed opportunity to sell their works.

At the least, what we need to create, is a site for a permanent art exhibition, where the artists, scattered around the world, could keep their work, and where their works could be bought, etc. (Minutes I: 27-28)

A decision was adopted during the same meeting, to form a working group with a task to make proposals for devising the collection, organise exhibitions and promote fine arts. The board members suggested the body of active members to elect a working group where the majority of persons would be in favour of modern art. However, as the attitude towards modern art, in the view of those involved in the Postimees newspaper, was hostile and narrow-minded, and the ENM was closely connected with these people, there were strong disagreements regarding the membership of the working group on art (Hinnov 1984: 11-12). 
Two months later, when commencing with the election of the members for the working group on art, the majority of the proposed persons, and wholehearted supporters of modern art - Bernhard Linde, Dr. Juhan Luiga, Friedrich von Stryk and Karl Menning - were left out. Thus, the intention to collect Estonian modern art failed due to the strong influence of the gentlemen in the Postimees newspaper. Thus, Kr. Raud, K. Burmann and Adolf Luiga, a student of the law faculty, were elected in the working group, and also Karl August Hindrey, a man with a suspicious attitude towards modern art movements, and Paul Raud and August Jansen, an art student in St. Petersburg, who represented academic art (Minutes I: 33). According to existing data, this was the first meeting when the establishment of an Estonian art museum was discussed, with the venue and initiators in Tartu (Linde 1931: 7). Unfortunately, the initial plans - to collect and promote modern Estonian art - were not implemented. The working group on art was the weakest of all the workgroups operating at the time in the Estonian National Museum, and was in no position to develop into an independent contemporary art museum.

The transfer of the ethnographic objects of the Estonian Museum in Tallinn, to the Estonian National Museum in Tartu, was a long and complicated process. Negotiations were launched between the museums in Tallinn and Tartu, concerning the possibility of exchanging the artefacts, whereas both these institutions wished to maintain a representative collection - the Estonian Museum in Tallinn wanted to preserve an ethnographic collection, and the Estonian National Museum intended to keep an art collection. According to Linde, longlasting negotiations failed due to the inflexibility of Tartu, as the ENM did not want to surrender the works of art kept in the museum (Linde 1931: 15). The relevant negotiations about the transfer of artefacts to the ENM commenced in 1926 and continued in 1936 and 1941.

\section{CONCLUSION}

Since the foundation thereof, the Estonian National Museum sustained and is still sustaining the idea of collecting, keeping and promoting the culture of Estonian people. Among a number of different domains, folk culture has always been the priority. The first decades of the 20 th century have secured the place in history as the period of large-scale heritage collection. Kristjan Raud, the main ideologist of these collection campaigns, has written about this in a passionate manner: 
We will not be silent, we will not be tired until every child in a village knows what the Museum is about, and until every farmstead has given their antiquities to the Museum. (Raud 1911)

This was the beginning of a major museum boom, the ideology of which was to find something from our past to be proud of, to search for the roots and the desire to prove to the whole world that Estonians, too, are a nation of culture.

In this article, I attempted to show that these ideas were also cherished by the Estonian National Museum in Tartu, and its department in Tallinn, which developed into the Estonian Museum Society in Tallinn, and thereafter, into the today's Art Museum of Estonia.

As it is always the case in history, a lot depends on individuals. Kristjan Raud was one of the key figures of this process; being an artist, he was passionate about heritage, and had initiated the collection of artefacts, for the Learned Estonian Society, as early as at the beginning of the 20th century. Raud was a wonderful organiser of collection endeavours, when in charge of the heritage collection working group of the Estonian National Museum, and later, as the chairman of the board of the Estonian Museum in Tallinn. Kr. Raud was an ideologist, A. Pulst, on the other hand, was an active hands-on person. Behind them was the ever growing and activating Tallinn-based membership of the ENM. The uniting force for these people was to rescue antiquities, to honour and praise their national culture, and by doing so, render value to the past. Indeed, one of the most important reasons, for the Tallinn Department to develop into a separate museum, was their aim to better organise heritage collection - to rescue the artefacts and folk culture. The relevant activities of the Estonian National Museum in Tartu had been more modest in war-time.

There is nothing surprising in the fact that the Tallinn Department of the Estonian National Museum became a competitor for the "parent museum". This is a natural course of events when two institutions are targeted towards the same direction. Competition is a constructive force and facilitates a better outcome. There is no doubt that Estonian cultural heritage has gained from this competition. The fact that A. Pulst could not send his Tori collection to Tartu, and had to instead take the artefacts to Tallinn, is not a reason for the emergence of a new museum, it is rather an impetus that launched the process. A national art museum and a museum reflecting folk culture are the two substantial pillars upholding the cultural history of a nation, regardless of the fact how these museums are named in different countries. The third large museum is usually the history museum, expressing the historical-political memory.

I was inspired to write the article in order to ascertain how the Tallinn Department of the Estonian National Museum developed. During the first 
years of the Republic of Estonia, folk culture was highly cherished, and seen as the source of motivation and inspiration for our artists. However, along with the development and participation in world culture, this direction gradually faded into the background. National romanticism had become outdated. The vast majority of the individuals, who were actively involved in museums and heritage collection at the time, have made their way to our cultural history primarily as artists.

In conclusion, it can be stated that thanks to these people and the two museums, we have a magnificent collection of Estonian folk culture which hopefully underlines the viability of our culture and will inspire artists during the forthcoming centuries, irrespective of fashionable trends. The Art Museum of Estonia should not be ashamed for being conceived from the Estonian National Museum.

\section{NOTES}

${ }^{1}$ Hereinafter referred to as the Estonian Museum in Tallinn (Tallinna Eesti Muuseum), this is also the most prevalently used name form of the institution.

${ }^{2}$ In 2009, the Estonian National Museum celebrated its 100th anniversary in Tartu, and the Estonian Art Museum marked the 90th birthday in Tallinn.

3 August Pulst was born to a farmer's family, on 14 January 1889, in Pärnu County, Tammiste rural municipality. He died on 22 November 1977 in Tallinn. Pulst graduated from the pro-gymnasium of the Estonian School Society in 1908, studied painting in the Art School of Riga during 1911-1915 and obtained a qualification as an art teacher. His supervisor was academician Vilhelms Purvitis. During 1915-1917, Pulst worked as a stage painter in the Estonian Theatre, participated in the establishment of the Tallinn Department of the ENM in 1916 and in founding the Estonian Open-Air Museum in 1926 (worked as a chairman in 1931). During 1919-1926 he worked as the secretary of the Estonian Museum in Tallinn, during 1932-1937 as a clerk in the Estonian Music Museum, and as the head of the Music Museum 19371944, and as a senior researcher in the Estonian Theatre and Music Museum 19441946.

${ }^{4}$ Tallinna Kaja No. 46, 21.11. (4. 12) 1915. pp. 721-736

${ }^{5}$ Number of Russian-language revolution related books - 167, brochures in Russian 178, communistic brochures in Russian - 241, Estonian language brochures - 302. Altogether 1,557 copies of archival material.

6 Both postcards were photographed by Johannes Pääsuke, the photographer of the ENM.

7347 artefacts and three paintings were obtained during the first year of operation: Laipmann's Landscape with a farmstead, August Jansen's Herding at night and Baldur Toomasberg's aquarelle Windmills on the island. In addition to artefacts, depositions included 17 paintings, four drawings and nearly 2,000 books and brochures. 
8 Actually, there were no qualified members of staff both in Tartu and in Tallinn. Helmi Reiman (Neggo) was the only employee in the ENM, during 1916-1917, who had studied ethnography at the University of Helsinki.

9 This was the time when the idea of creating the task force for the rescue of Estonian heritage (Eesti Muinasvara Päästetoimkond) was conceived.

\section{ABBREVIATIONS}

ERM = Estonian National Museum

ERMA = Archive of the Estonian National Museum

ERM EAV = Ethnographic Archive of the Estonian National Museum. Varia

ERM Fk $=$ Photo collection of the Estonian National Museum

\section{ARCHIVAL SOURCES}

\section{The Archive of the Estonian National Museum}

Miscellaneous loose-leaf material of the Tallinn Department of the ENM 1919-1920. ERM inventory 1, record 588:

Minutes of the board meeting of the Tallinn Department of the Estonian National Museum:

Minutes 5/1918 = Minutes No. 5, June 4, 1918

Minutes 6/1918 = Minutes No. 6, September 11,1918

Minutes 15/1918 = Minutes No. 15, November 28, 1918

Minutes 16/1918 = Minutes No. 16, December 18, 1918

Minutes 1/1919 = Minutes No. 1, February 3, 1919

Minutes 10/1919 = Minutes No. 10, May 13, 1919

Minutes 13/1919 = Minutes No. 13, May 30, 1919

Minutes 15/1919 = Minutes No. 15, June 5, 1919

Minutes 16/1919 = Minutes No. 16, July 5, 1919

Minutes 17/1919 = Minutes No. 17, July 30, 1919

Minutes 18/1910 = Minutes No. 18, August 4, 1919

Minutes 20/1919 = Minutes No. 20, August 20, 1919

Minutes 22/1919 = Minutes No. 22, August 28, 1919

Minutes 23/1919 = Minutes No. 23, September 6, 1919

Minutes 24/1919 = Minutes No. 24 (no date)

Minutes 25/1919 = Minutes No. 25, October 4, 1919

Minutes 26/1919 = Minutes No. 26 (no date)

Minutes 28/1919 = Minutes No. 28, October 28, 1919

Minutes 30/1919 = Minutes No. 30, November 12, 1919

Activity report = Eesti Rahva Muuseumi Tallinna Osakonna I. tegevuse aasta aruanne 12-st maist kuni 1-se jaanuarini 1919 "Estonia” teatri majas. [Activity Report of the 1st year of Operation of the Tallinn Department of the Estonian National Museum, from May 12 to January 1, 1919, in the Estonia Theatre building.] 
Course programme = Eesti Museumi Ühing Tallinnas 1920 a. Ainelise vanavara korjamise kursuste kava. [Estonian Museum Society in Tallinn. Course on the Collection of Tangible Heritage. Programme.]

Minutes I = Eesti Rahva Museumi" tegevliikmete kogu ja juhatuse protokollid 1909 kuni 1913. I. [Minutes of the general assemblies of active members and the board of the "Estonian National Museum" from 1909 to 1913.] ERMA inv. 1, r 8.

Minutes II = Eesti Rahva Museumi Protokolli-raamat II. Juhatuse ja üleüldiste liikmete ja tegevliikmete koosolekute protokollid. [Minutes-book of the Estonian National Museum II. Minutes of the general assemblies of the board, members and active members of the Estonian National Museum.] 03.02.1914 - 03.06.1918. ERMA inv. 1, r. 9

Protokoll I = Eesti Rahva Muuseumi Tallinna Osakonna peakoosoleku Protokoll nr I 11. mai 1919. [Minutes No. I of the 1st General Assembly of the Tallinn Department of the Estonian National Museum, May 11, 1919.]

Rules of Procedure = Eesti Rahva Muuseumi Tallinna Osakonna KODUKORD [Rules of Procedure of the Tallinn Department of the Estonian National Museum.]

\section{Ethnographic Archive of the Estonian National Museum. Varia}

Pulst $1973=$ August Pulst 1973. Minu tööst seoses rahvakunsti - etnograafiaga. [About my Work in Connection with Folk Art - Ethnography.] Manuscript. ERM EAV 26. $102 \mathrm{pp}$.

\section{Archive of the Art Museum of Estonia}

Paas 2004 = Paas, Heini. Eesti Kunstimuuseumi ajaloost 1919-1944. [About the History of the Estonian Art Museum 1919-1944.] Manuscript.

Pulst $1948=$ August Pulst 22.09.1943 - 2.12. 1948. Eesti Muuseum Tallinnas. Ajaloolisi andmeid. Aug. Pulst. [Estonian Museum in Tallinn. Historical Data. Aug. Pulst.] Manuscript. 205pp.

\section{REFERENCES}

Estonian Museum in Tallinn 1922 = Eesti Muuseum Tallinnas. Ajutine nimestik. [Estonian Museum in Tallinn Temporary List of Records.] Tallinn, 16pp.

Estonian Museum in Tallinn 1923 = Eesti Muuseum Tallinnas. Ajutine kataloog. [Estonian Museum in Tallinn Temporary Catalogue.] Tallinn, 16pp.

Estonian National Museum 1918 = Eesti Rahva Museum 1916 ja 1917. Eesti Rahva Museumi väljaanne nr. 15. [Estonian National Museum 1916 and 1917. Publication of the Estonian National Museum No. 15.] Tartu.

Hinnov, Virve 1984. Eesti Rahva Muuseumi kunstikogu. [Art Collection of the Estonian National Museum.] Etnograafiamuuseumi aastaraamat XXXIV. [Yearbook of the Ethnographic Museum XXXIV.] Tallinn: Valgus, pp. 11-28. 
Leinbock, Ferdinand 1934. Eesti Rahva Muuseum 1909-1934. [Estonian National Museum 1909-1934.] Tartu: ERM Ar. IX/X.

Linde, Bernhard 1931. Eesti kunstimuuseumi mõtte areng ja Tallinna Eesti Muuseumi Ühing. The Evolvement of the Idea Concerning the Estonian Art Museum and the Estonian Museum Society in Tallinn.] Eesti Kunstimuuseumi aastaraamat I. [Yearbook of the Art Museum of Estonia I.] Tallinn: Tallinna Eesti Muuseumiühing, pp. 5-32.

Matto, Gustav 1916. Vanavara korjamine 1915. a. [Heritage Collection 1915.] Eesti Rahva Muuseum 1915. Eesti Rahva Museumi väljaanne nr. 12. [Estonian National Museum 1915. Publication of the Estonian National Museum No. 12.] Tartu.

Õnapuu, Piret 2006. Foreword. Vanavara kogumisretkedelt 2. August Pulst. [Heritage Collection Expeditions 2. August Pulst.] Tartu: Estonian National Museum, pp. $5-27$.

Õunapuu, Piret 2007. Eesti Rahva Muuseumi algaastate suurkogumised. [Large-scale Collection Campaigns during the First Years of the Estonian National Museum.] Eesti Rahva Muuseumi aastaraamat L. [Yearbook of the Estonian National Museum L.] Tartu: Estonian National Museum, pp. 11-42.

Õunapuu, Piret 2009. Tallinna Osakond. [The Tallinn Department.] Eesti Rahva Muuseumi 100 aastat. [100 Years of the Estonian National Museum.] Tartu: Estonian National Museum, pp. 96-99.

Paas, Heini 1980. ENSV Riikliku Kunstimuuseumi ajaloost. Muuseumi rajamisest ja tegevusest 1919-1940. Kogude teatmik. Artiklid 1979. [About the History of the State Art Museum of the Estonian SSR. The Establishment and Operation of the Museum 1919-1940.] Tallinn: Eesti NSV Kultuuriministeerium, Eesti NSV Riiklik Kunstimuuseum, pp. 31-41.

Päevaleht 22 Nov 1918 = Toetage Museumi ettevõtet - pidu! [Support the Museum Enterprise - Party!] Päevaleht newspaper No. 29.

Postimees 25 Aug 1921 = Muinasvara Ruhnu saarelt. [Antiquities from Ruhnu island.] Postimees newspaper No. 191.

Promotion address $1910=$ Eesti III kunstinäituse üleskutse 1910. [Promotion address for the III Exhibition of Estonian Art.] Päevaleht newspaper No. 64, March 19.

Pulst, August 1915a. Eesti rahwa riided ja kirjad (mustrid). [Estonian Folk Costumes and Patterns.] Päewaleht newspaper No. 239, October 17.

Pulst August 1915b Meie esivanemate mälestused. [The Memories of our Ancestors.] Tallinna Kaja, No. 46, 21.11. (4.12), pp. 721-736.

Raud, Kristjan 1911. Eesti Rahva Museumi lill. [Flower of the Estonian National Museum.] Postimees newspaper No. 182, August 16.

Tallinn Museum 1927 = Tallinna Muuseumi ajutine kataloog. Tallinn Jaanuar 1927. [Temporary Catalogue of the Museum in Tallinn. January 1927.] 32pp. 


\section{NEWS IN BRIEF}

\section{DISSERTATION ON HIDDEN TREASURES IN ESTONIAN TALE TRADITION}

Mare Kalda's Doctoral thesis, Rahvajutud peidetud varandustest: tegude saamine lugudeks [Hidden Treasures in Estonian Tale Tradition: From Deeds to Folk Legends] (2011), provides an extremely exciting and diverse insight into Estonian treasure tradition, encompassing relevant archival texts, media coverings of different eras, associations of treasure tales with literary language, personal experience and landscape. The introductory part of the dissertation is a voluminous theoretical overview of the main characteristic features of treasure lore, earlier research done in the field (pp. 15-26), archival context (pp. 27-59), genre

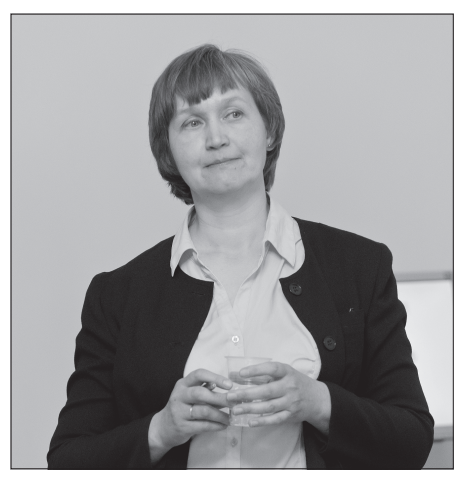
related issues (pp. 60-93) and typology (pp. 94-105, 131-141), followed by four articles focusing on more specific subject matter: the relationship of the 16th century cobbler's treasure tale with contemporary and later imaginations of the supernatural (article I, Kalda 2007); (inter)textual context of Kreutzwald's folk tale Whining Shinbone (article II, Kalda 2008); connections between the media text and legends in journalism during the first half of the 20thcentury (article III, Kalda 2003); and the relationship of legends and landscape in the case of riverside communities (article IV, Kalda 2004). It is possible to perceive a slight discrepancy between the two parts of the dissertation: whereas the first part is aimed at setting limits to treasure lore as such, proceeding from rather traditional folkloristic theories and keywords; the articles, on the other hand, are primarily centred on the engagement of new source materials and theoretical options. Still, the common denominator for both parts of the dissertation is the author's diversity in her points of interest and broad approach, particularly evident when comparing the whole thesis with earlier treatments on this subject matter, given in the chapter on research history. Indeed, besides the purely treasure tradition related issues, there are several themes highlighted in the introductory part and in the articles which are also expressive and of relevance to wider folkloristics (e.g. genre related issues, relationship between the media and tradition, archival context).

Kalda underlines that she proceeds from the standpoint that folklore is an ongoing process, and quotes Lauri Honko's idea of folklore as an organic part of living culture which "is recreated [...] in new performances with individual features" (Honko 1998: 57, op cit p. 10). However, when Honko meant turning away from archive-centred folkloristics then Kalda asks as to what has been the role of archives (or more broadly, archiving and written recording) in the more general process of treasure tradition: how do texts end up in archives, how are they studied and exhibited there and what is the relationship of the archival texts with these outside archives (and with the reality and landscape), and what kind of events and circumstances motivate the re-actualisation of archival records (see, e.g., pp. 27-28). 
As people are in the centre of such processes, the focus on the process would also mean that consideration is given to the reality of the informant (individual) (see p. 11): why have these stories been told and written down, read, listened to and delivered, and how and in what contexts has this happened. It is difficult (and also interesting) to detect the reality of the informant as the majority of sources at the disposal of a treasure tradition researcher contain the traces of the reality of several people - consideration has to be given to the viewpoints of the storyteller and the person writing it down (see pp. 39-59), the tradition bearer as the author of a journalistic (sensational) story (see article III), and to these of the true believer as a rational interpreter (see article I). In addition, it is necessary to bear in mind the era-wise, religious, institutional and social contexts wherein all these above-mentioned persons function, and who they want to speak to, and what kind of medium or genre do they use for conveying their message.

Kalda aims at understanding the motivating factor behind the different folklore collectors who participate in the treasure lore process, and has grouped them according to the ways/methods of textualisation, using the following indicators: the proportion, content and development level of treasure tradition texts in the contributions of folklore collectors, and the emphasis in the comments added by the correspondents (p. 41). Thus, she differentiates between six groups: those telling their story (pp. 42-43), frontal collectors (pp. 43-48), collectors oriented at local tradition (pp. 48-51), collectors achieving at self-accomplishment (pp. 51-54), and the socially active ones, engaged in several domains (pp. 54-56), and also schoolchildren (pp. 56-59). Intrinsically of any division in humanities, these types of correspondents are not fully exclusive and quite a few of the collectors might fall into several groups - e.g. the work-style of some schoolchildren is similar to that of frontal collectors (see p. 56), and the difference between frontal collectors and those aiming at self-accomplishment mainly lies in the bulk of collected material (see p. 51). Still, irrespective of this, the typology is indeed very detailed and comprehensive and is definitely worthwhile to be applied by archival researchers engaged in other subject matters, or at least be used as a source of inspiration. For example, I presume that the locally oriented collectors could also have another orientation (targeted at religion, history or fairy-tales, etc.) in other fields of research.

With an aim to underline the ongoing process, Kalda has convincingly implemented the intertextuality theory. For instance, in the article on Torsten Grön's personal narrative, the concept of intertextuality has been used on one hand to analyse the accordance of different tale elements with the belief context of the observed era - revealing that the motifs and beliefs expressed in the tale were actually part of collective tradition, although the tale itself was an individual textualisation. On the other hand, Kalda also highlights the intertextual connections of this personal narrative with the personal narratives of today, spread on the Internet (see article I).

In her treatment on Kreutzwald's legend Whining Shinbone, Kalda uses the theory of intertextuality, in order to analyse the archival texts with the implications of Kreutzwald's legend. This, in turn, is not intertextuality at the level of motifs and beliefs, but an intertextual field with a very concrete textualisation in its centre. Attempting to differentiate between these two options of intertextual relationships, Kalda 
underlines that the observed phenomenon is intra-textual, rather than inter-textual: "The present study, however, focuses on intratextuality, a narrower and more limited field of intertextuality, since it explores the relations between the recurrent emergences of what is basically the same text" (Kalda 2005: 102-103; article II: 51). Although such a use of concepts allows the revelation that the textual field is based on a particular base text, I am not quite convinced in the meaningfulness of such a differentiation. In the end, we can never be sure of how direct is the relationship between the archival text and that of Kreutzwald's textualisation - all the relevant written records in the archives do not only proceed from the text by Kreutzwald, they are also in relation to the textual experience of each individual recorder (and potential previous narrators, readers, etc.) - a fact that can be considered within intertextuality and what tends to be left unnoticed within intratextuality. (And it seems that Kalda herself is not too sure about the need to highlight the intratextuality of the text field - in the summary of the article within the introduction of the dissertation, she describes this as intertextuality (see p. 15, 108, 112.)

Thus, when reading these very impressive and detailed applications, it is somewhat unexpected that when presenting her theoretical and methodological standpoints in the introductory part of the dissertation, Kalda does not use the concept of intertextuality, and states modestly that she "continues with the traditions of Estonian folklore analysis by way of applying comparative research and source criticism" ( $p$ 13). As much as I can note, she mentions intertextuality (in addition to the content summaries of the articles) only once, in the conclusion (p.106), whereas if this theory had been tied with the highlighted analysis traditions, it would have been an opportunity to connect the first part of the dissertation with the articles. Likewise, it would have been interesting to see how the theory of intertextualisation could be related to genre theory or the localisation of the plots of migratory legends.

One of the issues concerning the reality of an informant is the relationship of treasure lore and the landscape. The landscape related aspect is indeed one of the dominant aspects of the dissertation and has been thoroughly dealt with in the introductory part (in connection with the collectors of locality-related tradition pp. 48-51; genre related aspect (pp. 65-73)) and also in the articles (being an ancillary in article I, yet relatively focal in the rest of the articles).

Part of this involves the question about the relationship between the story and reality as a large number of tales and notices refer to specific places where treasures have been or could be found. On several occasions, Kalda repeats the argument by Tõnno Jonuks, namely, that the immediate purpose of the treasure tales is to mark the significant places in the landscape, whereas the initial meaning of the locality might have been very unique (p. 71, 89; see Jonuks 2010: 69). She also refers to Kent Ryden's idea that the physical, historical and emotional geography are of great significance in the localisation of internationally spreading legend plots (p. 66, see Ryden 1993: 83). Thus, the task of a folklorist is not to ascertain whether, where and what has actually been buried somewhere, but instead, to ask as to what is so special in the place concealed in the narrative, for a concrete person or a lore group, so that they need to highlight this specificity by telling the story; what has been this something in certain places that has facilitated the actualisation and localisation of the plots of migratory legends. 
The second keyword here is identity: localised treasure tales, placed in local relationships serve as an interesting opportunity to observe the difference between the "our" and the "other". Kalda argues that when studying the local variants of widely spread plots it is interesting to observe "how the narrators of these tales have commented upon the situations when it turns out that their unique story had also happened somewhere else" (pp. 66), and illustrates this with the reaction of one of Bengt af Klintberg's informants: "Ah, the tale about grandfather's gold coin has spread that far!"(af Klintberg 1990, op cit p. 66).

A somewhat different distinction, between the "own" and the "others", seems to be intrinsic of the legends about unknown treasure hunters (see, e.g., pp. 70, article III: 116-121). Kalda notes that although the plots of these tales are widely spread internationally, it is not expedient to talk about migratory legends; it is rather a case where a similar, "initially a real-life situation" has inspired a "similar narrative" (p. 70). Still, the emphasis should not only be put on similar real life events - instead, this is a case where treasure tales are being used in order to explain the non-understandable deeds committed by unusual people (strangers). It is indeed quite exciting that even archaeologists and other researchers of heritage can potentially occur in the centre of such a narrative, in addition to land surveyors or persons who have actually been on the spot and trying to dig out the treasure.

As much as treasure tales are part of tradition, they have also been part of the metalanguage which underpins the relevance of folklore. Both Jakob Hurt and Matthias Johann Eisen have used a metaphor - old gold - in the reports and appeals regarding folklore collection, and have referred to heritage collectors as gold-diggers (see, e.g., p. 29, and also Valk 2004: 268-269), relying, supposedly, on the more general use of the metaphor complex in the national-romantic treatment of the past (see references on $\mathrm{p}$. 29). The use of such metaphors can be frequently seen in the letters sent by Hurt's and Eisen's folklore correspondents, and we can be quite sure that the collectors of folklore who used this metaphor actually interpreted this imagery proceeding from the local understandings and examples, from local treasure lore, rather than from the international background. Thus, the relevant reflections at grass-root level can be seen as a distinctive parallel to the localisation of the plots of international migratory legends.

To conclude, it is nice to see that the author of the dissertation is eagerly ready to apply the treasure-hunter metaphor to her personal field of research - Kalda notes that "the task of researcher(s) is to [...] rediscover the treasures which are as if hidden in archives" (p. 29). In addition to the continuity of research history, the adoption of such a metaphor is also a way to relate oneself to the informant's level.

\section{Katre Kikas}

\section{References}

Honko, Lauri 1998. Folklooriprotsess. [Folklore Process.] Mäetagused 6, pp. 56-84. Jonuks, Tõnno 2010. Kohapärimusest Lahemaal. In: A. Paulus (comp.) Uurimusi Lahemaa ajaloolistest maastikest. Teadusartiklid kultuuripärandist. [Research on Historical Landscapes of Lahemaa. Articles on Cultural Heritage.] Tallinn: Huma, pp. 63-76. 
Kalda, Mare 2003. Jutud peidetud varandustest. Pärimus ja meedia. [Narratives of Hidden Treasures. Heritage Media.] Mäetagused 20, pp. 96-129.

Kalda, Mare 2004. Siinpool jõge - sealpool jõge. Mõne Emajõe-äärse koha loost. (On Both Sides of the River: The Local History on the River Emajõgi.] Mäetagused 27, pp. 73-104.

Kalda, Mare 2005. Maastik vinguva jalaluuga. Ühest muistendist Friedrich Reinhold Kreutzwaldi muinasjuturaamatus. [Landscape with a Whining Shinbone. On a Legend in the Folk Tale Anthology by Friedrich Reinhold Kreutzwald.] Mäetagused 28, pp. 99-122.

Kalda, Mare 2007. Mõisakingsepa isikukogemuse lugu Rõngu kirikuraamatus ja muistendikogumikes. [A Manor Cobbler's Personal Experience Narrative in the Records of Rõngu Church and in Legend Anthologies.] Mäetagused 35, pp. 95-114.

Kalda, Mare 2008. Landscape with a Whining Shinbone: On a Legend in the Estonian Folk Tale Anthology by Friedrich Reinhold Kreutzwald. Folklore. Electronic Journal of Folklore 40, pp. 45-72.

Klintberg, Bengt af 1990. Do Legends of Today and Yesterday Belong to the Same Genre? In: L. Rörich \& S. Wienker-Piepho (eds.) Storytelling in Contemporary Societies. Script Oralia 22. Tübingen, pp. 113-123.

Valk, Ülo 2004. On the Discursive Foundations of Estonian Folkloristics: a Farmer's Field of Vision. In: E. Kõresaar \& A. Leete (eds.) Everyday Life and Cultural Patterns. International Festschrift for Elle Vunder. Tartu: Tartu University Press, pp. 265-272.

\section{THESIS DEFENCE: PIRET VOOLAID}

\section{ESTONIAN RIDDLES AS A FOLKLORE GENRE IN A CHANGING CULTURAL CONTEXT}

\section{Piret Voolaid: Eesti mõistatused kui pärimusliik muu- tuvas kultuurikontekstis. [Estonian Riddles as a Folklore Genre in a Changing Cultural Context.] Dissertationes folkloristicae Universitatis Tar- tuensis 16. Tartu Ülikooli Kirjastus, Tartu 2011. 238pp.}

Piret Voolaid's thesis is composed of an introductory chapter and six articles published earlier on different forums.

In the introduction Voolaid looks at riddles and the research on them from many different points of view and presents several theories that can be used in the study of riddles and, particularly, in the study of the special riddle genres, i.e. conundrums, compound puns, acronyms, droodles, that she herself is interested in. As Voolaid states in the introduction, earlier traditional riddles were considered to be in the centre and the above-mentioned subgenres were considered as peripheral. But now 
the situation is vice versa: today conundrums and other subgenres seem to form the central genre of riddles, whereas traditional riddles have become nearly extinct, i.e. only those traditional riddles are known that have been printed, for example, in schoolbooks. Perhaps the complete change in the riddling tradition tells us about the loss of the earlier homogeneous culture, and, naturally, about the important role of the mass media in present-day culture.

Voolaid has presented many different folklore theories in the introductory chapter, which is typical of a doctoral thesis. Sometimes it can also be problematic, if these theories are not used in the analysis. In this case several of them - but not all - have been used in the analysis of riddles, however not very explicitly. This is due to the fact that the introduction has been written after the articles.

The references and the bibliography used are thorough and versatile ranging from Anglo-Saxon to Russian ones. As the thesis involves modern subgenres of riddles, the emphasis in the bibliography is on new sources dealing with the relevant phenomena, and the studies on traditional riddles are not quoted extensively.

The thesis is, in a way, the apology for archives. Archives are often conceived of as a mere stock of data, collected in order to preserve ancient knowledge from fading. The author has herself created the databases for Estonian conundrums, compound puns, acronyms, abbreviation formulae, initial letter puzzles, attention tests, calculation trick questions, puzzles of relatives and droodles. The first article, Mõistatuste perifeeria digitaalsed andmebaasis aastal 2006. Vahefiniš [Digital Databases of the Periphery of Riddles in 2006. Interim Finish], gives a good review of these genres and their special features and of the additional information that is given about them in the database. At the same time, the article reflects the difficulties in creating a classification, a typological taxonomy of these less studied genres.

In the article Mõistatusžanri uuemaid arengusuundi 1992. ja 2007. aasta koolipärimuse kogumisvõtluse taustal [Recent Developments of Riddle Genre on the Basis of 1992 and 2007 School Lore Collections in Estonia], Voolaid tells about the data collection among schoolchildren in the years 1992 and 2007 and of the changes that can be seen in the riddle tradition. The material shows the peripheral position of traditional riddles in modern society. In this article Voolaid clearly shows the socio-cultural aspect of her study; very interesting and true is her observation that the traditional riddles did not indicate the attitude, but rather, attitudes were expressed through joking. Nowadays, on the other hand, humour seems to be the key component in new riddle sub-genres.

Interesting is also the remark about the non-oral transmission of new folklore genres, i.e. they are transmitted not only orally but very often literally through the Internet. This is, of course, known to everybody who is familiar with present-day riddles, but it is quite contradictory to most of the earlier definitions of folklore.

The article Zoofolkloorseid aspekte eesti keerdküsimustes, liitsõnamängudes ja piltmõistatustes [Animal Lore in Estonian Conundrums, Compound Word Games, and Droodles] studies the Estonian conundrums, compound word games (compound riddles) and droodles containing some animal name. The amount of such riddles is large, according to Voolaid about one fourth of the Estonian conundrums and nearly one third of the droodles contain animal names. Many of these are based on zoological absurdities. Especially in the case of compound word games the absurdity is based on fixed phrase metaphors, dead metaphors. 
In the article Humorous interpretations of abbreviations as a socio-cultural phenomenon, Voolaid presents the types of abbreviation riddles and their formation formulae. These are based on humour and therefore she uses humour theories to interpret them. Most of the older examples are connected with different phenomena of the Soviet era. Voolaid adopts the idea of code-mixing for acronyms based on Russian but being interpreted with Estonian words. This seems a linguistically plausible solution.

In the article Narrativused piltmõistatused - mitme folkloorižanri piirinähtus [Narrative Droodles or Droodle Tales - a Border Case of Riddles and Narratives], Voolaid describes narrative droodles as a combination of riddle + tale + drawing + humour + play, which presuppose an interactive act of communication between the one posing the question and the one answering it. They have also been called pseudo-riddles or quasiriddles by earlier researchers. Voolaid has tried to analyse this odd genre with relatively different methods than in case of other riddles. I do not find the comparison with Vladimir Propp's or Alan Dundes' theories too fruitful, but the author does not seem to be very happy with them, either.

The last article, Carrying a wolf, a goat, and a cabbage across the stream. Metamorphoses of ATU 1579, brings us to the second life of folklore postulated by Lauri Honko. It gives a picture of the narrative being formed into a droodle, and the life of the droodle in different Internet games and websites, i.e. the second life of droodles as computer games. Voolaid sees in this the multi-modality or multi-mediality or creolity of folklore.

Piret Voolaid's thesis offers very interesting insights on less studied subgenres of riddles, which have become very popular during the last four decades, she presents a valid analysis and, at the same time, creates a taxonomy of these subgenres.

Sirkka Saarinen

\section{FRAGMENTS FROM THE CONVENTION OF ETHNOGRAPHERS AND FOLKLORISTS}

\section{SIEF CONGRESS IN LISBON, APRIL 17-21, 2011}

\section{P103. Uneasy places: shifting research boundaries and displacing selves.}

P203. Narrative space in a multicultural city.

The panel on Uneasy places aimed at interdisciplinary discussion on the connection on how social action and the places shaped by way of this are mutually interrelated, proceeding from a theoretical standpoint that socially framed places are not shaped merely by the free will of people, and more often than not do not speak of neutral feeling of belonging. Rather, the decisions about the associations of belonging are disputable, as this is to do with a constantly changing process due to social interaction, and can be assessed from several viewpoints at a time, and these assessments may refer to the belonging that has not been strived for, and to a wish to belong together, yet this desire has not been achieved. Research on the spaces with concrete boundaries, and the ac- 
tivities associated with these places (e.g. religious acts, diasporic communities, criminogenic areas, tourism sites, etc.) attempts to describe these places in the context of the reciprocal relationships of the social groups therein, and also in relation to power, etc.

All ten presentations in this panel represented an ethnographic or cultural anthropology related research, whereas the most frequently used methods comprised interview, participant observation, ethnographic description, etc. As the speakers were mainly either from Brazil or Massachusetts, USA, the focus of observation was also put on the Americas. In general, the presentations fell into four larger categories with regard to their subject matter: tourism and travel, youth culture and socio-symbolic borders in urban space; confined space; migration, race and identity. The papers based on the research of tourism and travelogues highlighted the constructed nature of spaces - the person visiting a place created this place from the fragments of urban life, i.e. from the details characteristic of today's middle class, by way of re-sequencing these details. However, contemporary interpretation of the 19th century travel journals leads to generalisations: the descriptions of towns and cities do not only include the pictures seen and experienced during the trip, but instead, this can also be understood as a structural whole, encompassing the elements of the described town and also the values attributed to the latter, which, in turn, depend on local, national and supranational contexts. This particular process is positioned in, e.g., a colonial or other type of historical context. The presentations dwelling upon youth culture underlined the issue of urban spaces and confinement experience. The specific characteristic of places concerning youth culture, and the moulding of social and symbolic boundaries, simultaneously refer to the confinement of this group and the relevant "place", and to the inevitable openness, to communication beyond the boundaries. As an example of such a situation, Otávio Raposo showed, using the example of the Maré district of Rio de Janeiro, how a relatively confined area of illegal activities (drug dealing, etc.) has at the same time become an open space - because of the youth group of break-dancers, as these dancers have created contacts with those involved in this activity in other regions. Ioana Florea, presenting the mutual relationships between the youth groups in post-socialist Bucharest, showed that the listening to music is one of the markers of group boundaries in public urban space, however, when doing so, unwritten rules, valid in this particular region, are being followed. If usually, listening to music is a coping practice in uneasy public spaces, the habit of one youth group - to listen to manele, a type of music of the Roma, and generally stigmatised - paradoxically tends to create additional tension between different social groups.

Presentations on confined spaces (prisons, urban areas of illegal activities) revealed the connectedness between the temporal places (either time-wise, as prison or concerning a specific action, such as drug-dealing) with neighbouring areas (incl., e.g., prison and outside the prison). The speakers focusing on the migration, race and the identity created there from, highlighted the categorisations concurrent with symbolic racial and ethnic boundaries, and the subject matter of neighbourhood, a logical cotheme when talking about boundaries. For example, Graça Cordeiro analysed the identity of the Portuguese-speaking community in Boston: they are linked by way of their place of residence (Boston) and language (Portuguese), yet distinguished by their historical past (they originate from different continents and have come to Boston due to different circumstances); this is the reason why the observed communities do not perceive themselves as a uniform linguistic community. Hence the focus of research - 
now, when living in the new environment, how is the new identity being created by way of the common language, i.e. how symbolic boundaries are being repositioned proceeding from the new context. Isabel Rodrigues referred to the problems concerning race and ethnicity as clearly defined categories, and to the politicisation of race in statistical records. Her research questions were associated with the differences between census data and ethnographic observations: although in both occasions, people are asked to determine themselves racially or ethnically, the ways to interpret these responses are indeed variable. In the particular case, the focus was on the category "another race": how the respondents had interpreted this and what were the conditions for them to make the particular choice they made (e.g. the desire of the Portuguese to be distinct from the Spanish - the Latinos). Bethan Harries asked a methodological question: how to investigate racial boundaries at a community level in a case where this topic is kept under wraps in public. According to research results, it is still possible to learn about these existing racial or ethnic boundaries, by way of the mutual positioning of these groups, or in other words - race related issues can be studied by way of studying the space.

The presumable inter-disciplinary nature of this panel was not evident as the majority of presentations were rather case studies than generalisations instilling theoretical discussion. Nevertheless, what was revealed was the dynamics of places, generated by the social practice which is of great significance in the creation of these places. Research examples reflected the domains not perceptible and available at first glance, associated with the daily interaction of small groups, subcultures and, in some instances, with the illegal world. Irrespective of the markers used to define a group and the place created within the activity of this community, it is always associated with the neighbourhood, impacting on the communication with other groups and places. Thus, the close observation of these communities (groups of minorities, subcultures and illegitimate groups, i.e. less prestigious communities) was a cross-section of the relatively concealed levels in society. However when the construction involved the permitted and valued social places (tourism, travelling), what prevailed were the models associated with thinking, and these models could even be more dominant than the actual real place.

The panel on Narrative space in a multicultural city analysed the place of migration and globalisation in modern urban culture. The urban cultures of different backgrounds (particularly in cases when such cultures have evolved due to migration) might not always act polyphonically, as different lifestyles need to function in a cooperative, and sometimes in a competitive manner. The presenters argued that the places created by minority groups (museums, churches, monuments, ethnic cuisines and shops, etc.) have remarkable symbolic relevance, besides the practical function of these places. The discussion centred around the question as to how are these above-mentioned places opened and understandable to the "other", including the tourists; would these spaces, created by minorities, yet striving towards openness, nevertheless remain the places associated solely with the minority groups, or can they also become a shared space? The presentations prevailingly proceeded from the ethnographic analysis of narratives, other types of texts, or that of museums and monuments. The observed areas mainly concerned Eastern and Southern Europe and Israel. The speakers demonstrated the construction of space from the viewpoint of migrating lifestyle (e.g. Russian "places" in Helsinki which are particularly persistent and multi-layered, with tsarist and post- 
Soviet strata evolving therein; or the presence of Russian and Soviet culture in Haifa, Israel, created by the community of people who had emigrated from the Soviet Union. The construction of monuments or other facilities, on the other hand, may also apply for the opposite - to restore "our" history, as shown in Goran Janev's presentation on Skopje, capital of Macedonia. Allegedly, nearly 50 monuments have been erected in city centre to symbolically emphasise mono-culturalism, instead of today's multiculturalism. At the same time, the Old Bazaar district in ancient Skopje represents cultural diversity through religious buildings, scents and sounds. Different formats of expressed multiculturalism in the city indicate that the processes concerning the multitude of cultures encompass the activities of diasporic communities and the attitudes of the public, incl. these of the power institutions, towards cultural reality.

Tiiu Jaago

\section{P113. Experiencing movement: subjectivity and structure in contemporary migra- tion.}

The aim of the panel on the subjective and structural aspects of contemporary migration was to underline the human facets of migration, in order to counterbalance economic and political aspects which tend to be the point of interest for a majority of articles and papers in migration related research. Ethnographic approach and the focus on personal narratives can facilitate the detection of subjective, emotional and existential dimensions of migration. Yet on the other hand, the researchers in the panel were also interested in theoretical conclusions and in a more in-depth understanding of the discussed phenomenon, rather than presenting merely illustrative examples. Such a theoretical approach was accentuated in the first presentation, given by Knut Graw, and observing the reciprocal implications of subjectivity and structure in migration from West Africa to Europe. Likewise, a number of other presentations in the panel looked at the migration from Africa to Southern Europe, relying on the fieldwork of the authors (in some instances, the fieldwork had been multi-local, i.e. conducted in the country of origin and country of destination).

Repeated themes of the presentations concerned uncertain temporality (lack of knowledge, not knowing the length of the stay in a particular place, and what would happen next), and the changing meanings of home in the eyes of the person. Genderspecific differences of migration were also discussed in several papers. Francesco Bruno Bondanini talked about the journey from Africa to Europe, referring to the camp for immigrants in Melilla, North-Africa. This site, officially a temporary centre, usually becomes a years-long "home" for the people who stay there from six months to five years, waiting for their "ticket" to Europe. And the return is also not without problems. Stephan Duennwald's presentation touched upon the African migrants' involuntary return "home" where they are not welcomed, even by their family members. The returnees (and also the emigrants) are expected in Mali to have money and be successful, this is particularly true in case of men. Migration is an opportunity for young males to quickly become a proper man: in a good case, this would mean not only experience but also money and thus the possibility to buy valued goods and provide for several women. Migration from this viewpoint is a successful return rather than going 
to another society. However, for the returnee, the country of origin might not be the same as it was when he once left.

A very interesting presentation, instilling contradictory thoughts was that of Kristin Kastner's, focusing on the body and gender-related aspect of migration in the case of Nigerian women in Morocco and Spain. Kastner referred to the Strait of Gibraltar as today's Iron Curtain the passing of which might take several years. Kastner's material speaks of the female body as an enormous resource in the migration process. The women who have already secured their place in Spain "support" the newcomers (girls) who have to pay back the borrowed sum by prostitution and will probably be similar "sponsors" in the future for the next newcomers. On the other hand, the body can be a resource when imitating pregnancy (with a pillow under clothes), in order to make it easier to cross the border. Fake pregnancy can also prevent becoming a rape victim. At the same time, pregnancy and giving birth in Spain provide better opportunities for staying in the country. Likewise, Bondanini also underlined, in his presentation on the North-African camp, that marriage and giving birth is the quickest way out for a woman.

Michael Westrich's presentation on illegal immigrants on the southern border of the European Union, where the refugees are given shelter by political activists, focused on the embodied experience of migration. The migrants had intentionally tried to change their body and its "codes" by self-mutilation to make it impossible to give fingerprints. Resistance, creativity and subjectivity were the other keywords of this presentation. Westrich underlined the creativity of the immigrants in coping with daily difficulties, attempting to access the sensual aspects of these experiences. I was deeply inspired by the way of presenting visual material in Kastner's and Westrich's research. Kastner had given the informants an opportunity to pose for photographs, in a place and with attributes chosen by themselves. Afterwards she sent the photos in a letter to the address given by the informants (e.g. to the family members and friends at home). On frequent occasions, the migrants wanted to be photographed with the socalled European attributes. This was as if a factory of dreams where they could present themselves in a way they wished to be seen by their close ones at home. Hence the question as to what a photo marks - whether a moment in the migration road (part of the process) or does it indicate a fact that the person has already got somewhere ( $\mathrm{am}$ done). People could tell their (dream) story by way of a photographic staging. Westrich showed beautiful film clips during his presentation and is intending to include these in his Doctoral thesis. Part of the clips were taken in cooperation with the informants, similarly to Kastner, e.g., a dance performed by a young man, combining the elements of traditional dance and that of modern dance acquired in the country of destination. This young man had personally asked the researcher to film him, with an aim to share the clip with his friends in Facebook. Such staged settings are an interesting object for analysis - how do the immigrants want to be seen and presented. What happens during the encounter of the expectations, the myth about Europe and the reality? It is also interesting to analyse these projects bearing in mind the dynamics of the relationship between the researcher and the person being researched: in this case the informant is also an initiator, he/she is more than an object of photographing, and can, to a certain extent, use the researcher in achieving his/her goals. Thus, both parties benefit from this encounter. 


\section{P206. Be-longing: ethnographic explorations of self and place.}

Coexistence of belonging and longing was one of the permeating themes in this panel. The focus was also on narratives and construction of places in the course of social interaction: how are people affected by the stories associated with different places, and how do these narratives mould their attitude towards the surroundings? How do people position themselves somewhere, merging the memories of the past, activities of the present, and the longing projected towards the future? The presentations also touched upon the role of the already non-existent places, imagined places and virtual places in people's lives. As in the previous panel, the papers mainly observed the recent migrants, yet this time mostly in Eastern rather than Southern Europe. The main issue was centred on the changing meaning of home, and discussion about the possibility of return. When do relationships with home alter to such an extent that return is no longer conceivable? How do people maintain contact with their old homeland when going back is not possible? The means for preserving these ties are not necessarily modern: Annikki Kaivola-Bregenhøj referred to cases of having seen one's home in a dream. Likewise, in the panel on the day before, mention was made of a woman who had climbed a high mountain to be "in contact" with her son living on the other side of the world. All presentations were based on ethnographic fieldwork or life histories. One worthwhile to be mentioned was the research by Petri Hautaniemi who studied the second generation of Somalians in Finland - the author has had contacts with these men, currently in their thirties, since the beginning of the 1990s - having the opportunity to observe them growing up as adults in the diaspora. Transnational identity has not always been perceived positively; it is of great significance in this context whether the person has been forced to move or has instead gone voluntarily (in this case the term "mobility" is used). Such mobility was represented by German-speaking pensioners - studied by Martina Kleinert - whose lifestyle was to cruise on yachts in the vicinity of New Zealand. This was a very interesting example of how the feeling of home and locality is being created when the person is settling in motion, i.e. constantly moving from one place to another, without any intention to stay somewhere permanently.

Pihla Siim

\section{TAKING MALTA OUT OF THE BOX}

The second interdisciplinary Island Dynamics Conference took place in Valletta, capital of Malta, on May 11-15, 2011. The conference was dedicated to the memory of recently departed Maltese folklorist G. Mifsud-Chircop. The main organiser and island research network leader Adam Grydehøj (Aberdeen University) was proud to present more than a hundred lectures from scholars representing 39 countries. The scope of research topics ranged widely - from archaeology to folkloristics, from history to economics, from musical studies to anthropology. The conference keynote speeches, delivered by David Lowenthal, Godfrey Baldacchino and Henry Glassie were colourful 
and well illustrated generalisations from outstanding researchers of their fields sharing their experiences.

Naturally, one of the focal points of the conference centred around the aspects of Maltese cultural life, tourism and economy. Isabelle Calleja Ragonesi, (University of Malta), discussed the linguistic skills of the Maltese people and predicted points of danger for the island's language usage. Malta has two official languages - Maltese and English. As she pointed out, the claim of perfect and equal bilingualism is a myth since users of one or either language lack a deep level of language skills. English also constrains Maltese in areas of fast innovation and change.

Another focal point of the conference was related to the structure of tourism, highlighting the many similarities in different regions of the world. Voon Chin Phua (Gettysburg College, USA) analysed long-term changes in a privately operated theme park of traditional Chinese culture - the park, popular in Singapore for decades, quickly lost its visitors after American-style changes and ticket price increase. Many papers were dedicated to the unique culture of specific islands, including discussions of why they have applied for UNESCO protection. That was the angle Felicite Fairer-Wessels (University of Pretoria, South Africa) used to broach the history of the small island of Robben off the southern end of the African continent. For centuries, the Robben Island had been a destination for deportations, but today the island and its prison milieu is part of the tourism industry.

Political and multiple era-encompassing problems, including expressions of identity and humanity, were the subject of numerous papers. For example, renowned American Italian folklore researcher Luisa Del Giudice (independent researcher, USA) talked about the Los Angeles city food programme for the poor where St. Joseph's Day is celebrated by filling the so-called Sicilian St. Joseph tables.

Overall, a number of impressive projects and discoveries were presented at the conference. For me, two from the archaeology section were most outstanding. MarieYvane Daire (Rennes University, Fance) introduced an international interdisciplinary research project concerning the Groix island, involving archaeologists, geologists and cartographers. Archaeological digging is accompanied by measuring GPS coordinates of historical monuments, thus creating map layers for the island and neighbourhood in different eras, which is further compared to geological data and results from laboratory analyses.

The Groix Island, $15 \mathrm{sq} \mathrm{km}$, is $11 \mathrm{~km}$ off the coast. Today, its population of 2200 make their living from fishing and tourism. The project observes and reconstructs the long history of the island - from prehistoric times up to the middle ages. The original settlers of the island (500 000-300 $000 \mathrm{BC}$, the Paleolithic era) erected monuments and used stone objects. The Mesolithic $(8000-5000 \mathrm{BC})$ is characterised by the many small stone objects from the time, the Neolithic (5000-2000 вC) and Bronze era (2000$800 \mathrm{BC})$ are characterised by various megaliths, menhirs and dolmens. Innovation is best seen in ceramic tableware (Neolithic, 3500-3200 BC, decorated clay pottery) and architecture. In the Iron Age ( $800-20 \mathrm{BC}$ ) the main economic trade was in salt production. Accordingly, new settlements arose in sites where seawater was turned into salt, but also the first fortified settlements come from that time. During the Roman period $(20 \mathrm{BC}-500 \mathrm{AD})$ settlement types and locations changed yet again, everyday objects were made mostly of metal and bone, but the most important legacy of the era was the establishment of the Lacarna harbour. From the Middle Ages (5-15 c. AD), the Groix 
Island features Viking burials, including Viking boat burials; warring apparel changes, including the developed forged metal parts. An important new line is the establishment of monasteries, which in turn influences fishing routes and the importance of fish as a food source.

The paper very aptly demonstrated on maps how settlements evolve - they are established and abandoned according to changes in economy and lifestyle. Changes in nature and usage of natural resources are limited by the island's limited resources. Production also meant adaptation to limited resources. We can also see more open and closed eras in the history of the island, when cultural and economic contacts with the continent are either important or shunned. Archaeology was an important source for constructing the lifestyle and influences in the island dwellers' life.

A comparison of ritual sites and memorials on the Easter Island, Ponhpei and Society Islands, presented by Reidar Solsvik (Kon Tiki Museum, Norway), demonstrated the role of archaeology in reconstructing the cultural pictures. Easter Island, with its mysterious monuments, has been a source of endless speculation for more than a century. Reidar Solsvik outlined the power relations and ritual needs necessary for erecting the monuments. Once again, the limited resources of an island were discussed, how they determine or even end a certain cultural phenomena. Thus it happened on two out of three volcanic islands, first established in 700-1000 AD, that it took a few hundred years before stone monuments were erected, coinciding with the time of cutting down the forest, and the settlements collapsed around 1550-1650. The Easter Island monuments, moais, are located on a special platform, which originally functioned as a temple and which later became part of the funeral complex. A total of approximately one thousand figures, one to ten metres high, some of them only roughly finished, were erected during 1300-1650. Similar temples on Society Island, with large monoliths and small figures, were established in 1300-1800. Exceptional is the island of Ponhpei where more than a hundred small artificial islands were created for temples - people first settled in $2000 \mathrm{BC}$ and the last monuments were erected in 400 BC. Nan Mado was an important religious and political centre where architecture accommodated for both death culture and festivities.

R. Solsvik emphasised that the largest changes took place within a short time period, approximately 400-600 years. In Austronesian culture, high status architecture was related to ancestor cult and memorisation, expressed in monoliths and stone sculptures created by a small society. In the end, several things coincided, leading to the depletion of the potential and resources of the societies that created this wonderful culture.

Each paper of this content-filled and multi-aspect conference was a filigrained presentation of novel results or long-term studies. Most of these papers will be published as articles available to the general public. However, those interested in island cultures might want to go and have a look at the portal dedicated to island studies information about upcoming events, island life news from all over the world, a blog and references to scientific publications. The site http://www.islanddynamics.org was created by Adam Grydehøj.

Estonian representatives Mare Kõiva and Andres Kuperjanov were supported by the Estonian Cultural Endowment and ESF grant no. 8137.

Mare Kõiva 


\title{
BOOK REWIEW
}

\section{WORDS AS EVENTS OR EVENTS AS WORDS?}

\author{
Venla Sykäri. Words as Events : Cretan Mantinádes in \\ Performance and Composition. Studia Fennica Folklo- \\ ristica 18. Helsinki: Finnish Literature Society 2011. \\ 234pp.
}

As emphasised on the book cover, the study of oral poetry in Finnish folkloristics has a long history. Unfortunately the source on which it was born in the 19th century, the kalevala-meter folk poetry, is not any longer a far-spread living tradition. Coming from prehistoric times, it was upstaged by modern devices of poetic selfexpression. Considering that, the community where the traditional folk poetry has survived the mass media age can be the most fascinating field of research for a Finn-

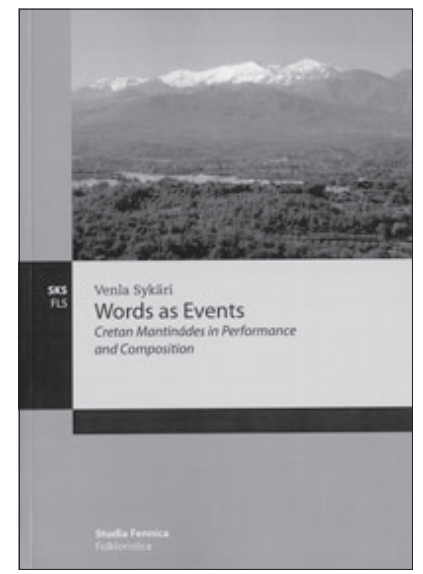
ish folklorist.

It would not be surprising if the reader has previously no idea what a Cretan mantináda is. Few studies about this tradition in French and English have hardly been available for many potential readers. Hopefully Venla Sykäri's book reaches a wider audience and fills that gap, because the mantinádes are really worth knowing also outside the tradition and among non-Greek speakers.

The mantináda consists of two rhymed fifteen-syllable lines which is the most common meter in Greek folk poetry and literature. A line contains two half-lines with the clearly marked caesura between them. The first half-line contains eight syllables with an obligatory stress either on the sixth or the eighth syllable and the second halfline contains seven syllables with an obligatory stress on the fourteenth syllable. The meter goes back to the Byzantine age, but the end-rhyme was introduced in Crete by the Western European literature model during the Venetian occupation between 1211 and 1669. The first systematic use of rhyme and the couplet form can be found in the late fourteenth century. The origin of the name mantináda is thought to be derived from the Italian mattinata 'a morning song' - a serenade-type vocal composition. Thematically the mantinádes cover a wide variety of topics, but first of all love and courting can be mentioned, while in traditional patriarchal Cretan village communities, a mantináda was the only possible way to communicate these subjects.

The mantinádes are traditionally sung in the gléndis, the annual and seasonal celebrations and the life-cycle celebrations where all members of the community took part, as the accompaniment for the dance with the national instruments or the part of ceremony, especially in weddings. The casual singing events are the informal gatherings of a paréa, a circle of male friends or relatives, until the 1980s the only way of casual entertainment among men and an important arena for social discourse. During the performances of a paréa, the poems sung are thematically linked to each other so that they form a thematic dialogue. But besides this, the mantinádes form part of the 
Cretans' everyday life in recited form, embedded into speech as proverbial, referential or meditative quotes, or in connection with recalling of the past performances or presentation of poetic inventiveness.

The changes in the economy, culture and technique have also caused some changes in performance contexts - the gléndis take place less and less frequently and the number of guests is reduced, the musical and singing activities are left to the professional musicians, traditional musical parées take place between those most dedicated to Cretan music and song. But the tradition is still alive: the new arenas open in television and radio programmes, newspaper columns, public competitions, and people use also mobile phones to archive and exchange the poems.

The creativity of the tradition consists not only in the composition of new poems which is highly evaluated yet not accessible for everybody, but also in the performing of contextually coherent poems from the common repertoire. By the words of one of the informants, Mitsos Stavrakakis: "That is, when young, the way you could communicate [with the other sex] was, either you played the mandolin and sung old mantinádes that you liked [...] or you made your own ones; when the existing mantinádes did not satisfy you, you made your own personal one. And this way you little by little understood if you had in yourself this poetic talent, which here they say, the most of us have." In such personal questions, those not capable of poetic creation could also ask help from their relatives or friends. The question of improvisation is also widely discussed through the book, summarising that there are two types of composers: those who in general can compose, and those who are spontaneous and capable of extemporising new poems on the spot, the latter ability not necessarily regarded as being any better.

The reserve of the poems of a modern tradition bearer consists of the verses from old written sources, most popular of them Erotókritos by Vizenzos Kornaros from about the year 1600 , to the newest compositions spread either anonymously or by known composers. The oral and literary have lived in an intertextual relation in Crete for a long time. The mantinádes have been written down and collected in notebooks for as long as writing has been possible. The verb gráfo 'to write' is used among others for the composition of the mantinádes, but the composers tell that writing down comes only after the poem is ready in their minds. Putting a mantináda into writing has never been regarded as a performance, but a way of storing - this is indeed an oral tradition.

Venla Sykäri calls her study an ethnographic register analysis. Based on the fieldwork which included living in a local village community for weeks and months during more than ten years and long-term relationships with the key informants, the study focuses on the questions of performance, communication, self-expression and creativity. From the viewpoint of the modern world, the author has tried to discern the characteristics of the poetic register which explain the contemporary perspectives and interest in it. She suggests that the creative challenges which draw people to mantinádes are the verbal, artistic playing with words and structures in the building of an image, the cognitive skills in making the point, and the experience of taking part in a dialogue. Besides being an excellent vehicle for social sharing and communication, a language of dealing and coping with one's experiences, the mantinádes are also the capital for local identity, while people in Crete generally suppose that similar verbal forms are not practiced by other peoples. A pure Cretan mantináda avoids the use of common language when local expressions are available, as well as foreign words, new or artificial 
words, slang, and idiomatic expressions of other Greek dialects. The poetic units are compact and easy to remember and they can be picked up and used by a much larger group of people than just the specialists. The metrical pattern of the poems is so natural to the Greek language that it is quite naturally recognised by any Greek and could unconsciously appear also when not suitable like the students' written exercises.

The study does not examine closer the texts of the mantinádes, just some references are given to couple of analyses. Briefly there is assumed that basic vocabulary of the productive register does not differ very much from the spoken idiom, but it leans heavily on shared idiomatic expressions, metaphors and metonyms. The lyric images and metaphors are most often taken from nature, and they are shared with other Greek folk poetry genres. The singularity of the mantináda genre is the compactness, putting the whole figurative idea into two verses. Especially in sentimental verses, the first verse typically contains a metaphor from nature and the second line links it to personal experience. Tens of examples translated into English which illustrate several aspects of the tradition still give the reader perception of its poetic charm. The images in the poems are simple, but sincere, cordial and often surprising. The first introduction to the tradition astonishes one with the universality of poetic attitude, suitable everywhere and always, without any sign of false shame. Venla Sykäri admits that regarding the aspect of privacy of emotional self-expression, Crete as a community differs from many others - the sentimental self-expression in poetic form is open to every member of community, also to tough men, not being the sign of weakness, and probably balances the otherwise rather severe qualifications for men's self-regard.

The question of men's and women's roles in the tradition is interesting, too. In the patriarchal village society women had less opportunity to perform, most of the arenas were reserved for men. But women were not excluded from these occasions, they were attentive listeners, the bearers of tradition in the families who memorised a lot of poems and taught them also to children. The modern arenas are likewise open to both sexes and the key informant of Venla Sykäri is a middle-aged woman Kostoula Papadoyanni who has developed her talent particularly with the help of mass media. One of her poetry's admirers is her husband, not verbally talented himself, but who enjoys and supports his wife's poems which give light to their common life. Sykäri has distinguished four types of creativity, depending on which is the relation between the creator, the situation of creation and the receivers and the last of them the creativity in perception - the experience through interpretation of the image is also a kind of creation. So we could say that the Cretans have a wonderful device in their possession which helps them all to be creators, in festive times and everyday life, giving their life extra value not so easily achievable without it.

Venla Sykäri's study gives an overview of the historical and cultural background of the mantináda tradition, as well as the interdisciplinary theoretical basis, the contemporary Finnish and international research on oral poetry and the anthropological research on communicative speech genres. The significant research results are presented mainly in the sixth chapter, Composition, and the seventh chapter A theory of dialogic oral poetry. The presentation of the theme starts already in the first pages of the preface where the fieldwork situations and key informants are acquainted from the aspects which do not come out anywhere else. For a person specialising in poetics rather than anthropology such an order of information sporadically seemed illogical 
and demanded returning to the parts already read. But the context of folk poetry - our life - is not profoundly logical itself. Words as Events shows us one kind of possibility how this context can be reborn in poetic expression, not only how the words can act as events, but also how the events form into words, dialogues of the witty and gentle poems.

I would like to end with my favourite mantináda from the book, composed by Kostoula Papadoyanni:

Krató to káthe s'agapó / pou lén' ta dio sou híli, osán kratá tis thálassas / ton ího to kohíli.

I hold every "I love you" / uttered by your lips, Like the sea-shell holds / the sound of the sea.

Kanni Labi 


\section{OUR AUTHORS}

Amots Dafni is Professor at the Department of Evolutionary and Environmental Biology, Institute of Evolution, Haifa University. Apart from pollination ecology, his main areas of research involve ethnobotany, typology and worship of sacred trees, ritual plants.

adafni@research.haifa.ac.il

Stephen Williams is a lecturer in the University of Glamorgan teaching sociology and social policy. He works in the faculty of Business and Society in Treforest. His PHD was concerned with fatherhood and social change, his other areas of interest include masculinities, families, politics, sport and social policies that follow from these areas.

smwilli3@glam.ac.uk

Mirjam Mencej is Associate Professor of Folkloristics and Mythology at the Department of Ethnology and Cultural Anthropology, University of Ljubljana. Her main research domains are belief legends, Slavic and European folk beliefs and customs, demonology, witchcraft.

mirjam.mencej@ff.uni-lj.si

Leyla Önal is currently a PHD candidate and studied sociology, communications and philosophy of art. Her research interests include feminist studies, cultural studies, media studies, folklore, mythology and sociology of religion.

leyla.onal@gmail.com

Elisabeth Piirainen is a leader of the project on European idioms. Her main research domains cover numerous languages and a variety of fields, such as dialectal and areal phraseology, gender specifics, cultural foundation of idioms. She currently works on the book on Widespread Idioms in Europe and Beyond: Toward a Lexicon of Common Figurative Units.

www.widespread-idioms.uni-trier.de

piirainen@t-online.de

Tatiana Deviatkina is Professor at the Department of Social Studies and the Humanities (Saransk Institute of Russian Consumers Cooperatives University). Her main research domains are Mordvinian mythology, marriage rites, songs, folk signs, 
interpretation of dreams. She is the author of the encyclopaedia Mordvinian Mythology (published in Russian, Mokshan, Estonian, English, and Arabic) and numerous books.

tatyana_devyatki@mail.ru

Tatiana Vladykina is Professor and senior research fellow at the Udmurt Institute of History, Language and Literature, Ural Department of the Russian Academy of Sciences. Her main research domains are Udmurtian mythology and folklore, belief system, calendar customs, songs, etc. She is the author of numerous books.

vlad@ni.udm.ru

Galina Glukhova is Associate Professor at the Chair of Udmurt and Russian Literature, Udmurt State University. Her research areas involve Udmurt folklore (calendar, calendar customs, masking, games) in Finno-Ugric contexts and Udmurt literature.

galant@udm.ru

Piret Õunapuu is a research fellow-curator in the Estonian National Museum. She is a member of the consultative Museum Board at the Estonian Ministry of Culture, and the editor-in-chief of the journal Muuseum. Her main research area is the history of the Estonian National Museum, culture of Estonian Swedes.

piret.ounapuu@erm.ee 